\title{
Contributions to \\ Mineral Resources Research, 1984
}

\section{U.S. GEOLOGICAL SURVEY BULLETIN 1694}

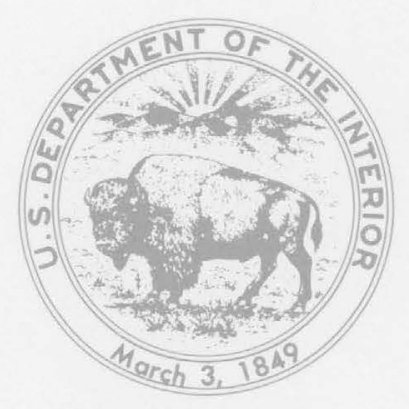


Contributions to

Mineral Resources Research, 1984

Edited by A.L. BUSH

Chapter titles are listed on

volume contents page

U.S. GEOLOGICAL SURVEY BULLETIN 1694 


\section{DEPARTMENT OF THE INTERIOR DONALD PAUL HODEL, Secretary \\ U.S. GEOLOGICAL SURVEY \\ Dallas L. Peck, Director

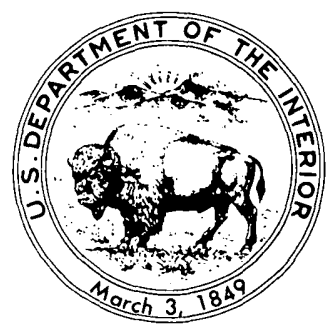

For sale by the

Books and Open-File Reports Section

U.S. Geological Survey

Federal Center

Box 25425

Denver, CO 80225

Library of Congress Cataloging in Publication Data

Contributions to mineral resources research, 1984.

(U.S. Geological Survey bulletin ; 1694A-H)

Includes bibliographies.

Supt. of Docs. No.: । 19.3:1694

1. Mines and mineral resources-United States. 2. Mines and mineral resources-Saudi Arabia. I. Bush, Alfred Lerner, 1919- . II. Series. QE75.B9 no. $1694 \mathrm{~A}-\mathrm{H} \quad 557.3 \mathrm{~s}$ [TN23] [553'.0973]

$86-600330$ 


\section{CONTENTS}

[Letters designate chapters]

(A) Authigenic potassium feldspar in the Davis Formation (Upper Cambrian), Missouri, by G.A. Desborough, J.J. Connor, and Maya Elrick 1

(B) Distribution, petrology, and mineral potential of peraluminous granitoid plutons in the eastern and southeastern Arabian Shield, Kingdom of Saudi Arabia, by Edward A. du Bray 13

(C) Muscovites from selected aplites and quartz veins of White Pine County, Nevada, by D.E. Lee, E.L.M. Brandt, and J.D. Gleason 33

(D) Chemical and stable-isotope data for micas from metaclastic rocks of eastern White Pine County, Nevada, by D.E. Lee, R.E. Van Loenen, E.L.M. Brandt, and J.D. Gleason 41

(E) Metallogeny of Archean and Proterozoic terranes in the Great Lakes region-A brief overview, by Paul K. Sims 55

(F) Sodium hypochlorite as an aid to the extraction of clay minerals from black shales, by Harry C. Starkey 75

(G) Platinum and palladium in a mafic dike, Sanders County, Montana, by R.E. Van Loenen, Joseph Haffty, and R.L. Earhart $\mathbf{8 1}$

(H) Metalliferous oil shale in the Upper Devonian Gibellini facies of the Woodruff Formation in the southern Fish Creek Range, Nevada, by George A. Desborough, Forrest G. Poole, Richard K. Hose, and Gregory N. Green 91 
Chapter A

\title{
Authigenic Potassium Feldspar in the Davis Formation (Upper Cambrian), Missouri
}

\author{
By G.A. DESBOROUGH, J.J. CONNOR, and MAYA ELRICK
}

Chemical and mineralogical studies of the Davis Formation show that very fine grained authigenic potassium feldspar, a major silicate, formed diagenetically at the expense of detrital vitric volcanic ash deposited in a marine environment 


\section{CONTENTS}

Abstract 3

Introduction $\mathbf{3}$

Lithofacies, chemistry, and mineralogy of the Davis Formation 4

General description 4

Section near Leadwood, Missouri 4

$X$-ray diffraction results 6

Chemical data 6

Comparison of the Davis Formation with other potassium feldspar-rich strata 9

Chemical and mineralogical characteristics of marine strata with a major authigenic potassium-feldspar component 9

Origin of authigenic potassium feldspar in marine strata 10

References cited $\mathbf{1 0}$

FIGURES

1. Map showing location of the Rolla $1^{\circ} \times 2^{\circ}$ quadrangle in Missouri 4

2. Maps showing thickness and lithofacies of the Davis Formation in the Rolla $1^{\circ} \times 2^{\circ}$ quadrangle in Missouri 5

3-5. Graphs showing concentration of elements versus $\mathrm{K}_{2} \mathrm{O}$, in samples from exposed section of Davis Formation near Leadwood, Missouri:

3. Barium versus $\mathrm{K}_{2} \mathrm{O}$ for 26 bulk samples 8

4. Zirconium versus $\mathrm{K}_{2} \mathrm{O}$ for 25 bulk samples 8

5. Rubidium versus $\mathrm{K}_{2} \mathrm{O}$ for 25 bulk samples 8

6. Graph showing concentration of boron versus ratio of potassium feldspar:illite-smectite for 28 samples at exposed section near Leadwood, Missouri 8

7. Diagram showing concentration of $\mathrm{K}_{2} \mathrm{O}$ versus $\mathrm{K}_{2} \mathrm{O}: \mathrm{Na}_{2} \mathrm{O}$ ratio for Precambrian, Cambrian, and Ordovician authigenic-feldspathic shales and siltstones in the midcontinent and Western United States and for insoluble residues from Ordovician carbonates of New York 10

TABLES

1. Chemical composition of shale samples of Davis Formation and Deadwood Formation 6

2. X-ray diffraction and chemical data for samples of dolomite, limestone, and shale, Davis Formation, near Leadwood, St. Francois County, Missouri 7 


\title{
Authigenic Potassium Feldspar in the Davis Formation (Upper Cambrian), Missouri
}

\author{
By G.A. Desborough, J.J. Connor, and Maya Elrick
}

Abstract

The chemistry, mineralogy, and texture of the Upper Cambrian Davis Formation are consistent with the concept that its silicate minerals originated chiefly from vitric volcanic ash that was deposited in a marine environment and then altered during diagenesis to potassium feldspar. Dolomite, calcite, illitesmectite, chlorite, and sparse glauconite and pyrite in the Davis also formed diagenetically. Quartz occurs in some beds and is largely detrital. Very fine grained authigenic monoclinic potassium feldspar is the dominant mineral in all insoluble residue samples and constitutes as much as 60 percent of many of the residues; only minor amounts of detrital igneous orthoclase and microcline (to $60 \mu \mathrm{m}$ ) are recognized in polished grain mounts and thin sections. By contrast, the authigenic potassium feldspar crystals are so small $(0.03-5 \mu \mathrm{m})$ that they can be conclusively identified by scanning electron microscopy, electron-microprobe, or X-ray diffraction methods.

That the silicate minerals in the Davis Formation are authigenic is also suggested by the composition and distribution of nearby igneous rocks. The Davis is thickest in the region surrounding the core of Precambrian igneous rocks that now form the St. Francois Mountains. These Precambrian granites and rhyolites were also exposed during Davis deposition, yet they contributed only a minor local detrital component to the Davis Formation. Evidence for this conclusion includes (1) the very high $\mathrm{K}_{2} \mathrm{O}: \mathrm{Na}_{2} \mathrm{O}$ (weight percent) ratio of $>55$, and (2) $\mathrm{K}_{2} \mathrm{O}$ contents of $10-11$ percent for beds in the Davis; these values are large compared with those for the local Precambrian igneous rocks. In addition, the $\mathrm{K}_{2} \mathrm{O}$, barium, zirconium, and boron concentrations for Davis samples differ significantly from the concentrations of these components in local Precambrian rocks. Further, the absence of quartz in some of the Davis samples, and the euhedral potassium feldspar grains smaller than $5 \mu \mathrm{m}$, taken with the other evidence preceding, all suggest an authigenic origin for potassium feldspar in many beds in the Davis.

The lower half of the marine Franconia Formation in Minnesota has been reported to contain nearly 50 percent authigenic potassium feldspar. These strata are age equivalent to the Davis Formation.

\section{INTRODUCTION}

In the past several years, highly potassic strata in which potassium feldspar is the major potassium-bearing mineral and also the major silicate mineral have commonly been considered to have originated from the diagenetic alteration of volcanogenic or tuffaceous debris. This interpretation has been applied to both lacustrine (Sheppard and Gude, 1965) and marine (Weiss, 1954) occurrences. Buyce and Friedman (1975) have emphasized these authigenic potassium feldspar occurrences in New York and in the upper Mississippi Valley regions for Upper Cambrian and Ordovician marine strata.

Our investigations of the mineralogy and chemistry of calcareous and dolomitic shales of the Upper Cambrian Davis Formation and the underlying Upper Cambrian Bonneterre Formation in the Viburnum trend mineralized area along the west side of the St. Francois Mountains, as well as prior studies of the chemical composition of shales (and other strata) in Missouri by Connor and Ebens (1980), revealed that some of these shales are highly potassic, and that the major potassium-bearing mineral is potassium feldspar. Samples previously collected by others from the northeastern and central part of the Rolla $1^{\circ} \times 2^{\circ}$ quadrangle in southeastern Missouri (fig. 1) were studied by us, and regional stratigraphic and lithofacies studies of Thacker and Anderson (1979a, b) for the entire quadrangle were subsequently useful for our interpretations. The bulk samples contain as much as 11 weight percent $\mathrm{K}_{2} \mathrm{O}$. Besides dolomite and calcite, the major minerals are potassium feldspar (orthoclase), disordered illite-smectite, and Fe-rich chlorite. Quartz may be absent or may form as much as about 30 percent of the noncarbonate fraction. Pyrite is generally detectable by X-ray diffraction in unoxidized samples. Potassium feldspar is the major mineral in most of the insoluble residues that were obtained by leaching the bulk samples with 20 percent $\mathrm{HCl}$; potassium feldspar is estimated to compose as much as 60 percent of the whole rock for those samples considered to be shale on the basis of grain size. Detrital orthoclase and microcline derived from local Precambrian igneous terrane are also recognized by chemical, X-ray diffraction, and electron-microprobe methods.

The bulk samples we studied were chiefly collected by others in the USGS for trace-element studies of metals and general lithologic character studies of the Davis 


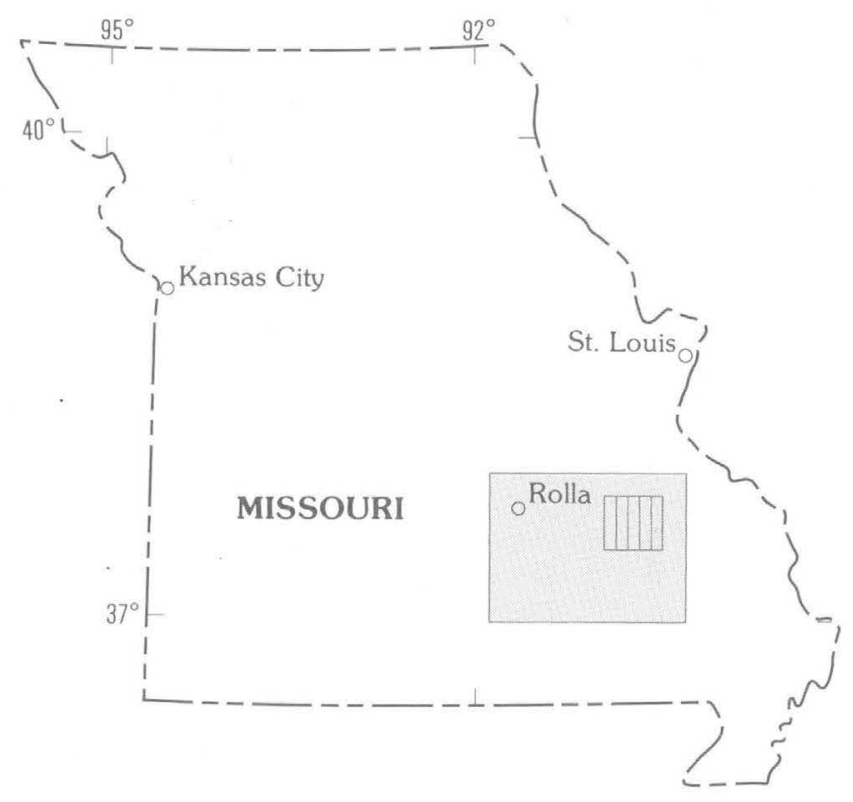

Figure 1. Location of the Rolla $1^{\circ} \times 2^{\circ}$ quadrangle in Missouri, with study area shown by vertical-lined box.

Formation. We used these samples collected by others because they were considered to be typical of the Davis Formation.

Kurtz (1975) proposed that the detrital component of the large volume of strata that makes up the Davis Formation in Missouri was principally derived from a northwesterly source. We present chemical, mineralogical, and other evidence that precludes as a major local source the Precambrian igneous rocks that were exposed to weathering and erosion at the time the Davis Formation was deposited. This evidence includes (1) dilution of the detrital component by carbonate buildup associated with relatively shallow water deposition peripheral to the exposed Precambrian igneous rocks of the ancestral St. Francois Mountains, (2) differences in chemical composition of the local Precambrian igneous terrane, compared with the composition of the silicates in the Davis Formation, (3) no widespread and (or) general increase in detrital components in the area proximal to the Precambrian igneous rocks exposed at the time of deposition of the Davis Formation, as shown by isopach and lithofacies maps, (4) little, if any, significant grain-size sorting of detrital components from the Precambrian igneous rocks exposed at the time of deposition of the Davis Formation, and (5) similarities in chemical composition and mineralogy with Paleozoic marine strata elsewhere believed to have a primary volcaniclastic origin. Collectively, these aspects led us to consider an exogenous or remote source for noncarbonate minerals in the Davis Formation and to examine chemical and mineralogical methods for evaluation of local versus remote source areas for the detrital material and how it might relate to the authigenic potassium feldspar.

\section{LITHOFACIES, CHEMISTRY, AND MINERALOGY OF THE DAVIS FORMATION}

\section{General Description}

Thacker and Anderson published isopach and sand:shale ratio maps (1979a), and carbonate:clastic ratio maps (1979b) of the Davis Formation for the Rolla $1^{\circ} \times 2^{\circ}$ sheet, which includes areas adjacent to the exposed, dominantly silicic, Precambrian volcanic and granitic rocks (fig. 2). Because much of the presently exposed Precambrian igneous terrane was also exposed during deposition of the Davis Formation, we thought that a comparison of the chemistry of the silicate components of the sediment with that of the igneous rocks could be used to determine whether or not the igneous rocks contributed a major component of clastic material to the Davis Formation. If not, then other sources would have to be considered. Whole-rock chemical data for more than 100 samples of exposed igneous rocks were reported by Pratt and others (1980), and 75 of these that were proximal to our study area were used for comparison with the Davis Formation chemistry. The ratio $\mathrm{K}_{2} \mathrm{O}: \mathrm{Na}_{2} \mathrm{O}$ was selected as the principal parameter for chemical comparison. By using $\mathrm{K}_{2} \mathrm{O}: \mathrm{Na}_{2} \mathrm{O}$, we excluded the variable amounts of quartz in both the sedimentary strata and the igneous rocks; additionally, the variable amounts of carbonate in the sediment were excluded. Chemical composition of four samples of shale from the Davis Formation obtained during the studies of Connor and Ebens (1980) are given in table 1. (The South Dakota sample is discussed later.) For these four shale samples, the $\mathrm{K}_{2} \mathrm{O}: \mathrm{Na}_{2} \mathrm{O}$ ratios are between 58 and 143 . In contrast, for the 75 compared samples of Precambrian igneous rocks exposed in the Rolla $1^{\circ} \times 2^{\circ}$ quadrangle north of lat $37^{\circ} 30^{\prime}$ N. (Pratt and others, 1980), the $\mathrm{K}_{2} \mathrm{O}: \mathrm{Na}_{2} \mathrm{O}$ ratios average less than 2 and range up to 87 . Only nine samples (12 percent) of the igneous rocks from that area have $\mathrm{K}_{2} \mathrm{O}: \mathrm{Na}_{2} \mathrm{O}$ ratios exceeding 10 ; only four samples have $\mathrm{K}_{2} \mathrm{O}: \mathrm{Na}_{2} \mathrm{O}$ ratios exceeding 40 .

In addition, the boron content (100-150 ppm) in the Davis (table 1) is several times that of the mean of $17 \mathrm{ppm}(<10-100)$ for 75 samples of Precambrian igneous rocks (Pratt and others, 1980). The zirconium content (70 ppm) in the Davis is less than one-third of the mean of $250 \mathrm{ppm}$ (70-500) for the same 75 igneous samples. Thus, on the basis of chemical data, it is unlikely that the insoluble residue fraction of the Davis was derived from the local Precambrian terrane of the ancestral St. Francois Mountains.

\section{Section near Leadwood, Missouri}

An interval of Davis Formation, exposed in a roadcut near Leadwood, was measured and sampled by the 

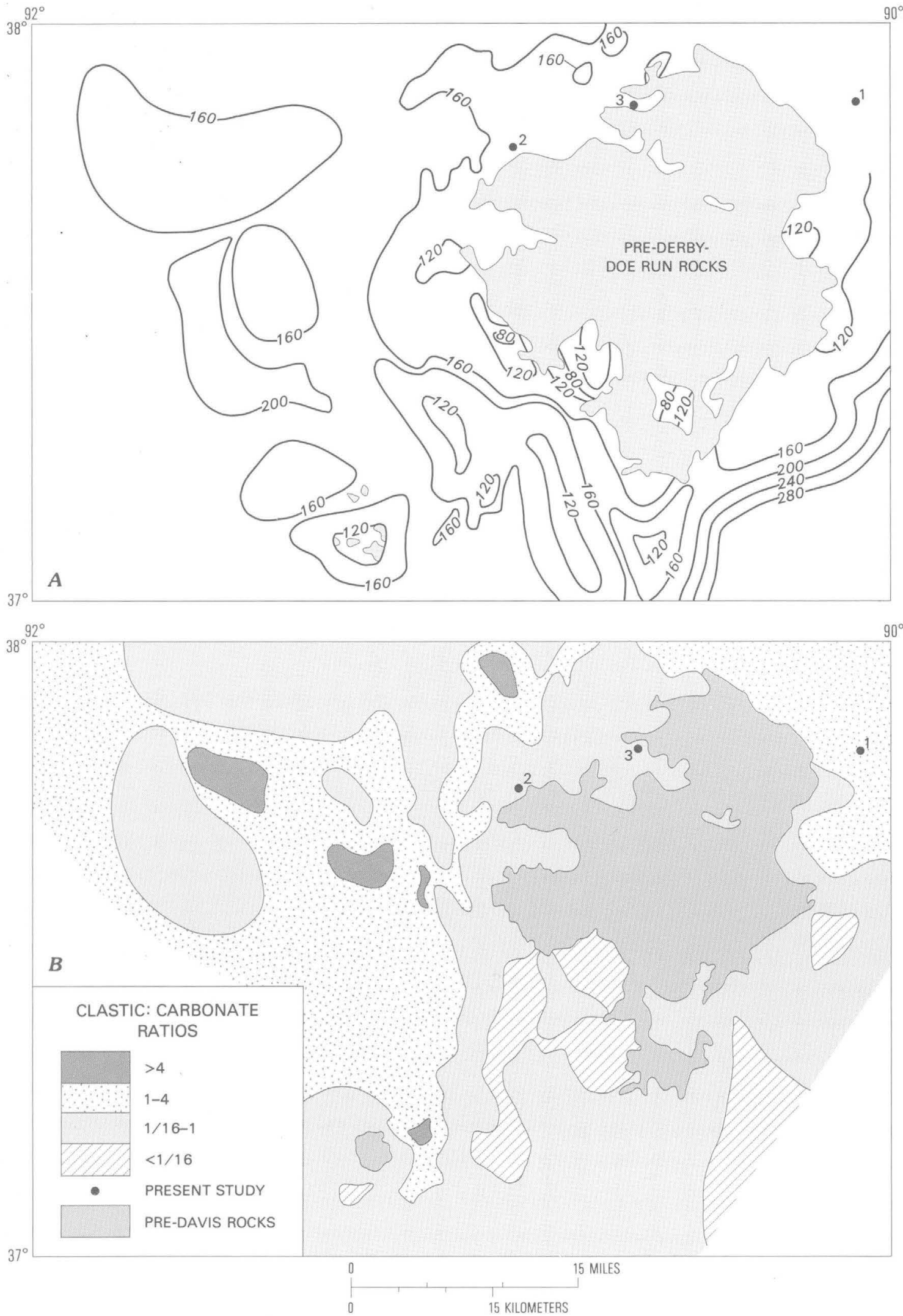

Figure 2. Thickness and lithofacies of the Davis Formation in the Rolla $1^{\circ} \times 2^{\circ}$ quadrangle, Missouri. $A$, Isopach map of the Davis Formation. Thickness contours in feet; contour interval $40 \mathrm{ft}$. B, Clastic:carbonate ratios of the Davis Formation. Both modified from Thacker and Anderson, 1979a, b. Sample localities: 1, 2, 3. 
Table 1. Chemical composition of four shale samples of Davis Formation, Washington and Ste. Genevieve Counties, Mo., and a feldspathic shale from the Deadwood Formation, Lawrence County, S. Dak.

[LOI, loss on ignition at $900^{\circ} \mathrm{C}$; n.d., not determined; 0 , excluded from total, contributed to LOI. All values in weight percent, except as noted]

\begin{tabular}{|c|c|c|c|c|c|}
\hline \multirow{2}{*}{$\begin{array}{l}\text { Sample No. } \\
\text { Laboratory-- } \\
\text { Field- }\end{array}$} & \multicolumn{4}{|c|}{ Davis Formation } & \multirow{2}{*}{$\begin{array}{c}\text { Deadwood } \\
\text { Formation } \\
\text { D120307W } \\
17 \mathrm{BBR} 2\end{array}$} \\
\hline & $\begin{array}{l}\text { D1 } 48004 \\
\text { REOSH05 }\end{array}$ & $\begin{array}{l}\text { D148015 } \\
\text { REOSH06 }\end{array}$ & $\begin{array}{l}\text { D147998 } \\
\text { REOSHO I }\end{array}$ & $\begin{array}{l}\text { D1 } 48090 \\
\text { REOSHO2 }\end{array}$ & \\
\hline $\mathrm{SiO}_{2}$ & 45.6 & 46.6 & 48.0 & 47.0 & 57.2 \\
\hline $\mathrm{Al}_{2} \mathrm{O}_{3}$ & 16.8 & 17.0 & 16.0 & 17.0 & 17.2 \\
\hline${ }^{l} \mathrm{Fe}_{2} \mathrm{O}_{3}$ & 3.8 & 2.8 & 4.8 & 4.4 & 5.2 \\
\hline MgO & 4.8 & 4.7 & 2.2 & 2.3 & 2.4 \\
\hline $\mathrm{CaO}$ & 5.7 & 5.4 & 6.4 & 6.4 & 2.5 \\
\hline $\mathrm{Na}_{2} \mathrm{O}$ & 0.17 & 0.07 & 0.08 & 0.13 & 0.14 \\
\hline $\mathrm{K}_{2} \mathrm{O}$ & 9.8 & 10.0 & 10.0 & 11.0 & 12.0 \\
\hline $\mathrm{CO}_{2}$ & $(0.8)$ & $(0.2)$ & 1.5 & 1.5 & 0.5 \\
\hline $\mathrm{TiO}_{2}$ & 0.5 & 0.7 & 0.5 & 0.5 & 0.7 \\
\hline$C$, organic & $(1.1)$ & $(2.7)$ & 0.1 & 0.3 & n.d. \\
\hline B (ppm) & 100 & 150 & 150 & 150 & $<10$ \\
\hline $\mathrm{Zr} \quad(\mathrm{ppm})$ & 70 & 70 & 70 & 70 & 100 \\
\hline LOI & 11.8 & 11.4 & n.d. & n.d. & n.d. \\
\hline Total--- & 99.0 & 98.7 & $\overline{289.6}$ & $\overline{290.5}$ & 97.8 \\
\hline
\end{tabular}

${ }^{1}$ All iron calculated as $\mathrm{Fe}_{2} \mathrm{O}_{3}$.

${ }^{2}$ Low total due to high content of fllite-smectite that contains hydration water.

Missouri Department of Natural Resources in 1977. This is our principal set of samples that are discussed in the following text. The measured stratigraphic interval is about $35 \mathrm{~m}$ thick, but there is a covered interval of unknown thickness between sample numbers 75 and 76 (table 2). The roadcut is only a few kilometers north of the Precambrian terrane that was exposed during deposition of the Davis Formation (fig. 2, locality 3). Thus, if Precambrian igneous rocks contributed significant detrital material to the Davis Formation, such detritus should be a major constituent of this locality. Twentynine composite samples (table 2) were assembled from 74 field samples of the Davis in the roadcut; each of the composite samples represents a lithologic unit recognizable in the field. We then studied these composite samples by X-ray diffraction of the bulk, chemical analysis of the bulk, and $\mathrm{X}$-ray diffraction of the 20 percent $\mathrm{HCl}$ insoluble fraction.

\section{X-ray Diffraction Results}

Dolomite:calcite ratios for composite bulk samples were semiquantitatively determined by measuring the relative intensities of the strongest $\mathrm{X}$-ray diffraction peaks of each mineral on diffractometer traces. Dolomite is dominant over calcite in 21 (72 percent) of the samples; dolomite and calcite occur in equal amounts in 2 samples, and 6 of the samples are dominantly calcite (table 2). About 60 percent of the interval had dolomite:calcite ratios in the range of 2 to 100 .

Silicate mineral contents of bulk samples were determined by X-ray diffractometer study of insoluble residues, which were obtained by leaching the bulk samples with 20 percent $\mathrm{HCl}$. Quartz is absent from seven lithologic units, aggregating 24 percent of the interval, in the middle and upper part (table 2). Quartz is dominant chiefly in the lower half of the Davis. Ratios of potassium feldspar to illite-smectite in insoluble residues were estimated on the basis of the X-ray diffractometer peak heights; the feldspar 002 peak near $27.52 \theta \mathrm{CuK} \alpha$ and the illite-smectite 001 peak near $8.9{ }^{\circ} \theta \mathrm{CuK} \alpha$ were used. The potassium feldspar:illite-smectite ratios range from 1.6 to 17 and indicate that potassium feldspar is dominant over illite-smectite in all analyzed samples (table 2). Potassium feldspar is the dominant mineral of the insoluble residue in 16 (of 29) samples, aggregating 62 percent of the interval studied (table 2). The potassium feldspar in the Davis is chiefly orthoclase, but three samples contain detectable microcline.

The quartz-free samples, except for one with abundant microcline, probably were derived from a source remote from the area of deposition, whereas those with quartz and abundant microcline were derived from thenexposed Precambrian igneous rocks of the ancestral St. Francois Mountains. This interpretation is supported by the following evaluation of the chemical data.

\section{Chemical Data}

To evaluate the possible sources of detrital sediment, the concentrations of $\mathrm{K}_{2} \mathrm{O}$, barium, rubidium, and zirconium were determined for most of the bulk samples by X-ray fluorescence analysis using standards with accurately known concentrations of each element; results are given in table 2 . Values for boron in insoluble residues were determined by M.S. Erickson in 1978 using semiquantitative emission spectroscopy: results for boron in table 2 are the mean for the samples in each interval.

Figure 3 shows the concentration of barium versus $\mathrm{K}_{2} \mathrm{O}$; on this plot, the linearity of the quartz-free samples is remarkable. In other words, the lowtemperature-formed potassium feldspar of authigenic origin incorporates much less barium than the igneous orthoclase of the Precambrian granites that is of detrital origin for the quartz-bearing samples. About 70 percent of the samples line along or very close to the "quartzfree" line, whose projected extension to the $\mathrm{K}_{2} \mathrm{O}$ content of pure potassium feldspar ( 16.95 percent $\mathrm{K}_{2} \mathrm{O}$ ) would indicate a concentration of about $450 \pm 30 \mathrm{ppm}$ barium in the authigenic potassium feldspar of the Davis Formation, if all $\mathrm{K}_{2} \mathrm{O}$ is in potassium feldspar. It is noteworthy that all samples that have a high barium 
Table 2. X-ray diffraction and chemical data for 29 samples of dolomite, limestone, and shale in the Davis Formation exposed along State Highway 8, SW1/4NE1/4 sec. 3, T. 36 N., R. 4 E., near Leadwood, St. Francois County, Mo.

[NA, not analyzed; mineral ratios determined by relative $\mathrm{X}$-ray peak intensities; $\mathrm{K}_{2} \mathrm{O}, \mathrm{Ba}, \mathrm{Rb}$, and $\mathrm{Zr}$ by XRF; analyst $\mathrm{M}$. Elrick; $\mathrm{B}$ by semiquantitative emission spectroscopy; analyst M.S. Erickson; q, quartz; K-f, potassium feldspar]

\begin{tabular}{|c|c|c|c|c|c|c|c|c|c|c|c|}
\hline \multirow[b]{2}{*}{$\begin{array}{l}\text { Sample } \\
\text { No. }\end{array}$} & \multirow[b]{2}{*}{$\begin{array}{l}\text { Thickness } \\
(\mathrm{m})\end{array}$} & \multicolumn{4}{|c|}{$\mathrm{X}$-ray diffraction data } & \multicolumn{5}{|c|}{ Chemtcal data } & \multirow[b]{2}{*}{$\begin{array}{l}\text { Igneous } \\
\text { orthoclase in } \\
\text { total orthoclase } \\
\text { (wt. pct) }\end{array}$} \\
\hline & & $\begin{array}{l}\text { Dolomite: } \\
\text { calcite } \\
\text { ratio }\end{array}$ & $\begin{array}{l}\text { Dominant } \\
\text { noncarbonate } \\
\text { mineral }\end{array}$ & Quartz ${ }^{2}$ & $\begin{array}{l}\text { Potassium } \\
\text { feldspar: } \\
\text { illite-smectite } \\
\text { ratio }\end{array}$ & $\begin{array}{c}\mathrm{K}_{2} \mathrm{O}^{\mathrm{l}} \\
(w t \cdot \mathrm{pct})\end{array}$ & $\begin{array}{c}\mathrm{Ba}^{\mathrm{l}} \\
(\mathrm{ppm})\end{array}$ & $\begin{array}{c}\mathrm{Rb}^{\mathrm{l}} \\
(\mathrm{ppm})\end{array}$ & $\begin{array}{l}2 r^{1} \\
(p p m)\end{array}$ & $\begin{array}{c}\mathrm{B}^{2} \\
(\mathrm{ppm})\end{array}$ & \\
\hline 7 & 0.30 & 100.0 & $q$ & + & 15.0 & 2.1 & 75 & 5 & 15 & 20 & 70 \\
\hline $8-12$ & 1.68 & 100 & $\mathrm{~K}-\mathrm{f}$ & + & 4 & 5.5 & 150 & 30 & 40 & 140 & 8 \\
\hline 13 & .45 & 100 & $\mathrm{~K}-\mathrm{f}$ & 0 & 6.5 & 3.6 & 65 & 15 & 15 & 150 & 0 \\
\hline $14-17$ & 1.22 & 40 & $K-\mathrm{f}$ & o & 4 & 7.8 & 200 & NA & NA & 200 & 0 \\
\hline 18 & .45 & 100 & $q$ & + & NA & 2.8 & 90 & 10 & 25 & 50 & 50 \\
\hline $19-23$ & 1.42 & 100 & $K-f$ & + & 3.4 & 8.1 & 220 & 65 & 55 & 220 & 0 \\
\hline $24-32$ & 2.9 & 100 & $K-f$ & + & 8 & 2.9 & 105 & 10 & 35 & 117 & 50 \\
\hline $33-37$ & 1.57 & 33 & $K-f$ & + & 5.7 & 9.6 & 355 & 115 & 105 & 280 & 20 \\
\hline 38 & .30 & 100 & $K-f$ & 0 & 11.5 & 2.2 & 30 & 15 & 5 & 100 & 0 \\
\hline 39 & .25 & 8 & $K-f$ & 0 & 2.5 & 10.8 & 315 & 150 & 95 & 500 & 0 \\
\hline 40 & .71 & 20 & $K-f$ & + & 7.5 & 2.1 & 22 & $<5$ & $<5$ & 200 & NA \\
\hline $41-47$ & 2.29 & 20 & $K-f$ & 0 & 2.4 & 10.4 & 310 & 135 & 80 & 500 & 0 \\
\hline $48-52$ & 2.44 & 0.1 & $K-f$ & 0 & 4.3 & 1.9 & 30 & 5 & 10 & 540 & 0 \\
\hline $53-58$ & 1.40 & 30 & $K-\mathbf{f}$ & 0 & 2.0 & 6.5 & 180 & 50 & 50 & 230 & 0 \\
\hline $59-63$ & 1.52 & 100 & $q$ & + & 9.0 & 7.9 & 500 & 80 & 160 & 110 & 55 \\
\hline $64-66$ & 1.93 & 1.0 & $q$ & + & 4.0 & 6.8 & 220 & 45 & 60 & 170 & 20 \\
\hline 67 & .61 & 0.3 & $K-f$ & + & 1.6 & NA & NA & NA & NA & 150 & NA \\
\hline 68 & .38 & 100 & $K-f$ & + & 3.3 & $\mathrm{NA}$ & NA & NA & NA & 100 & NA \\
\hline $69-70$ & .71 & 0.3 & $q$ & + & 2 & NA & 525 & 120 & 145 & 200 & $\mathrm{NA}$ \\
\hline 71 & .20 & 0.6 & $q$ & + & 7 & 7.1 & 325 & 40 & 115 & 100 & 40 \\
\hline 72 & 2.13 & 0.1 & $q$ & + & 17 & 9.5 & 590 & 85 & 180 & 100 & 55 \\
\hline 73 & 1.93 & 0.1 & $K-f$ & + & 4 & 10.6 & 600 & 115 & 160 & 100 & 50 \\
\hline 74 & 1.22 & 2.5 & $q$ & + & 10.5 & 5.2 & 350 & 45 & 130 & 100 & 65 \\
\hline 75 & .71 & 1.7 & 9 & + & 12.6 & 7.4 & 425 & 60 & 140 & 100 & 55 \\
\hline 76 & 1.47 & 1.0 & $q$ & + & 6.6 & 6.4 & 190 & 25 & 100 & 70 & 10 \\
\hline 77 & 1.75 & 2.0 & $q$ & + & 7.5 & 5.9 & 190 & 30 & 80 & 100 & 20 \\
\hline 78 & 1.07 & 1.2 & $q$ & + & 5.2 & 4.2 & 110 & 20 & 45 & 100 & 10 \\
\hline 79 & 1.98 & 13 & $q$ & + & 11 & 7.4 & 275 & 60 & 75 & 100 & 30 \\
\hline 80 & .33 & 7 & $K-f$ & + & 5 & 5.6 & 160 & 45 & 45 & 200 & 15 \\
\hline
\end{tabular}

concentration-in the range of $300-600 \mathrm{ppm}-$ contain quartz, which is inferred to be detrital. The higher concentration of barium in some of the quartz-bearing samples is attributed to the detrital igneous orthoclase, that formed at higher temperatures, and which was locally derived from the Precambrian terrane of the St. Francois Mountains (fig. 2). The average content of barium in 75 igneous rock samples with more than 5 percent $\mathrm{K}_{2} \mathrm{O}$ is $1,000 \mathrm{ppm}$ (calculated from Pratt and others, 1980); of the 75 samples, those that are granites average $625 \mathrm{ppm}$ and range from 300 to $1,500 \mathrm{ppm}$ barium. The granites with high orthoclase content typically have more barium than those with a relatively high content of microcline.

Figure 4 shows the relationship of zirconium to $\mathrm{K}_{2} \mathrm{O}$ concentration for the Davis Formation (table 2). For the quartz-free (nonlocal detrital contribution) samples, it is obvious that the concentration of zirconium versus $\mathrm{K}_{2} \mathrm{O}$ is linear, within the precision of the method. However, 44 percent of the Davis samples with inferred local detrital contribútion contain very high zirconium concentrations. The mean for 40 samples of igneous rocks in the area that contain more than 5 percent $\mathrm{K}_{2} \mathrm{O}$ is $270 \mathrm{ppm}$ zirconium, which is more than 2 to 3 times higher than the mean for the Davis Formation. The zirconium content of $70 \mathrm{ppm}$ obtained by emission spectroscopy for four samples of Davis (Connor and Ebens, 1980) shown in table 1 , that also contain 10-11 percent $\mathrm{K}_{2} \mathrm{O}$, is in excellent agreement with contents of 80 and $95 \mathrm{ppm}$ zirconium for the two quartz-free samples from the Leadwood section having the highest $\mathrm{K}_{2} \mathrm{O}$ concentrations (table 2 and fig. 4). The distribution patterns on figures 3 and 4 are similar and suggest that samples with high concentrations of both barium and zirconium had a local detrital source.

Figure 5 shows the content of rubidium versus $\mathrm{K}_{2} \mathrm{O}$ concentration; the relationship is curvilinear for all samples, but the quartz-free samples have a rubidium: $\mathrm{K}_{2} \mathrm{O}$ ratio equal to or higher than those samples that contain quartz. The two quartz-free samples with highest $\mathrm{K}_{2} \mathrm{O}$ concentration also have the most rubidium (fig. 5). These two samples and the quartz-free sample with 


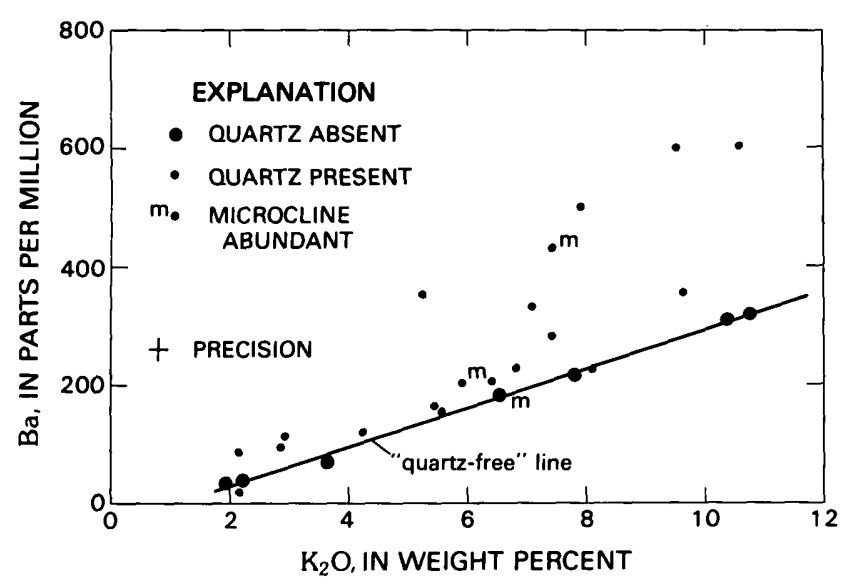

Figure 3. Concentration of barium versus $\mathrm{K}_{2} \mathrm{O}$ for 26 bulk samples of Davis Formation at exposed section near Leadwood, Mo.

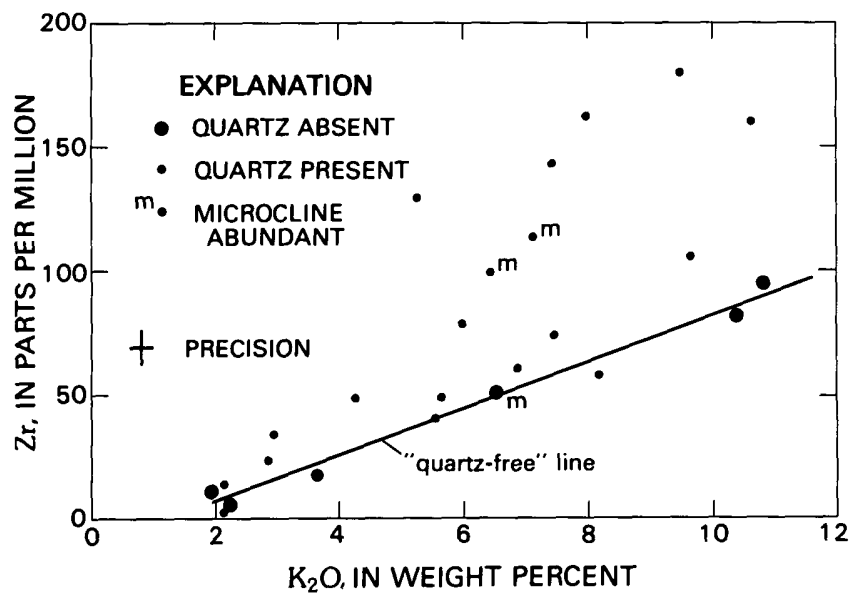

Figure 4. Concentration of zirconium versus $\mathrm{K}_{2} \mathrm{O}$ for 25 bulk samples of Davis Formation at exposed section near Leadwood, Mo.

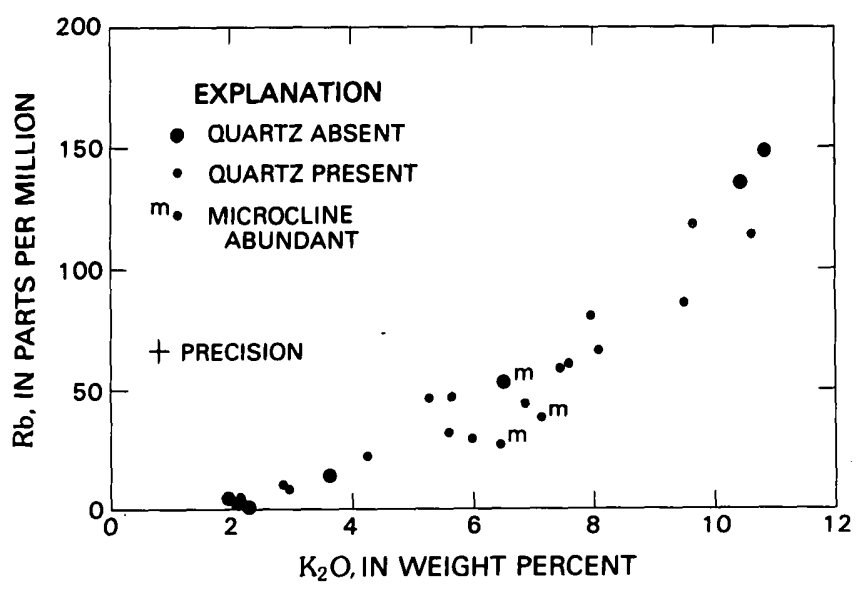

Figure 5. Concentration of rubidium versus $\mathrm{K}_{2} \mathrm{O}$ for 25 bulk samples of Davis Formation at exposed section near Leadwood, Mo.
$50 \mathrm{ppm}$ rubidium also have low ratios $(2.0-2.5)$ of potassium feldspar:illite-smectite (table 2); therefore much or most of the rubidium in these samples is in illite-smectite, and the authigenic potassium feldspar contains little if any rubidium. This situation accounts for the curvilinear relations between rubidium and $\mathrm{K}_{2} \mathrm{O}$ (fig. 5). The illitesmectite also contains both $\mathrm{K}_{2} \mathrm{O}$ and rubidium. The authigenic potassium feldspar contains less than $70 \mathrm{ppm}$ rubidium, but the illite-smectite contains about 200$300 \mathrm{ppm}$ rubidium, on the basis of calculations using the high and low rubidium contents for the quartz-free samples and the estimated potassium feldspar:illitesmectite ratios.

Figure 6 shows a generally inverse relationship between boron concentration in the insoluble residues and the ratio of potassium feldspar:illite-smectite. However, the three samples having the highest boron content have nearly twice as much boron as any of the other samples. This is probably due to the reporting intervals (for example, $100,150,300,500 \mathrm{ppm}$ ) for the semiquantitative emission spectrographic method. In general, the relations on figure 6 indicate that boron is chiefly in illite-smectite. The amount of boron in illite-smectite is estimated at $700-1,000 \mathrm{ppm}$, on the basis of calculations using the boron content, potassium feldspar:illite-smectite ratios, and $\mathrm{K}_{2} \mathrm{O}$ content of the bulk samples. Boron substituting for aluminum in potassium feldspar has an effect on the $a$ and $c$ cell dimensions when present in concentrations of more than about $600 \mathrm{ppm}$ (Martin, 1971; Sheppard and Gude, 1965, 1973). Cell parameter data obtained for potassium feldspar in these samples show that no more than about $500 \mathrm{ppm}$ of boron could be in either the detrital orthoclase or the authigenic potassium feldspar. This contrasts sharply with lacustrine authigenic

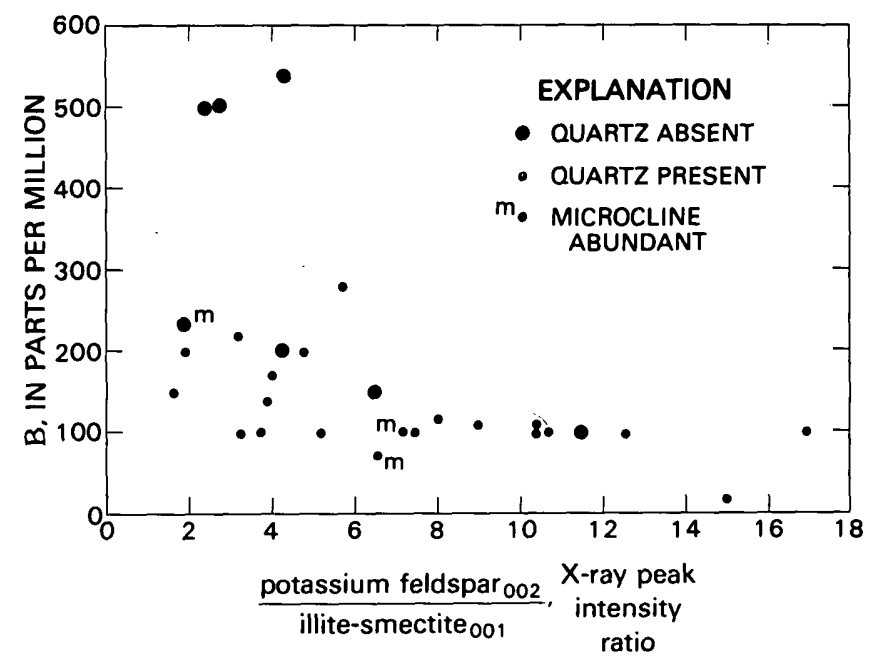

Figure 6. Concentration of boron versus ratio of potassium feldspar:illite-smectite for 28 samples at exposed section near Leadwood, Mo. 
potassium feldspar in Tertiary strata that commonly contains 2,500-4,400 ppm boron (Sheppard and Gude, 1965,1973 ). As noted, the low boron values (mean $=17$ ppm, range $<10-100 \mathrm{ppm}$ ) for the Precambrian igneous rocks of the St. Francois Mountains (Pratt and others, 1980) are consistent with the premise that boron in the Davis Formation is chiefly in authigenic illite-smectite, but some boron is also in authigenic potassium feldspar according to the integrated chemical and mineralogical data.

\section{COMPARISON OF THE DAVIS FORMATION WITH OTHER POTASSIUM FELDSPAR-RICH STRATA}

Several years ago, Buyce and Friedman (1975) discussed aspects of the authigenic potassium feldspar occurrences in Upper Cambrian and Lower and Middle Ordovician marine strata of several States including New York. In New York they studied insoluble residues of carbonate strata of Late Cambrian, Ordovician, Silurian, and Devonian age. They concentrated on the Lower Ordovician Tribes Hill Limestone that contains abundant potassium feldspar (12.1-23.9 normative percent) in carbonate beds that contain about $2.5-4.0$ percent $\mathrm{K}_{2} \mathrm{O}$; Upper Cambrian carbonates contain similar abundances (Buyce and Friedman, 1975, p. 814). Tester and Atwater (1934) first recognized marine rocks that consist mainly of authigenic potassium feldspar in Upper Cambrian and Lower Ordovician strata in Minnesota. Subsequent studies in Minnesota and Wisconsin of Upper Cambrian and Lower and Middle Ordovician marine strata that are enriched in potassium feldspar include those of Gruner and Theil (1937), Berg (1952), Weiss (1954), Woodard (1972, 1974), and Odom (1974). The potassium-rich intervals described by these investigators are less than about $10 \mathrm{~m}$ thick for Minnesota (Berg, 1952) and Wisconsin occurrences, although Bowie and others (1966) reported intervals as much as $16 \mathrm{~m}$ thick that average 9.5 percent $\mathrm{K}_{2} \mathrm{O}$ in Lower Cambrian marine strata of northwest Scotland.

The Proterozoic Dripping Spring Quartzite in Gila County, Ariz., contains marine strata as thick as $34 \mathrm{~m}$ that consist predominantly of potassium feldspar and contain as much as 14 percent $\mathrm{K}_{2} \mathrm{O}$ (Granger and Raup, 1964; Nutt, 1981).

We recently recognized shale beds consisting chiefly of authigenic potassium feldspar in the Upper Cambrian Deadwood Formation in the Black Hills of South Dakota; chemical composition is given in table 1. Barnes and Bell (1977) described abundant authigenic potassium feldspar that constituted more than 60 percent of the sand and silt fraction of the Franconian Point Peak Member of the Wilberns Formation (Upper Cambrian) in west- central Texas. The Point Peak Member is as much as $60 \mathrm{~m}$ thick, but it is limestone in the upper half (Barnes and Bell, 1977, p. 23).

Thus three widely separated marine basins of Late Cambrian age in Missouri, South Dakota, and Texas have high contents of authigenic potassium feldspar. We suggest that the potassium feldspar in these strata formed by the process suggested by Sheppard and Gude (1973): vitric volcanic ash in a diagenetic environment of high $\mathrm{pH}$ was chemically modified to potassium feldspar. Determining whether these marine strata with very high contents of potassium feldspar represent single or multiple volcanic events requires further detailed investigations, including paleontological, isotopic, mineralogical, and chemical studies.

The Davis Formation, which is more than $60 \mathrm{~m}$ thick where it is chiefly noncarbonate (Thacker and Anderson, 1979a), is certainly the thickest Paleozoic formation on the North American craton that has authigenic potassium feldspar as the principal noncarbonate mineral. If the precursor were volcanic ash, the volcanic event or events might have had significant effects on the biota, as well as on sedimentation.

\section{CHEMICAL AND MINERALOGICAL CHARACTERISTICS OF MARINE STRATA WITH A MAJOR AUTHIGENIC POTASSIUM FELDSPAR COMPONENT}

We have used a simple chemical method for the recognition of marine strata that contain more than about 50 percent of potassium feldspar that is authigenic. Figure 7 illustrates the chemical method that uniquely identifies strata (or their insoluble residues) that are rich in authigenic potassium feldspar, by plotting $\mathrm{K}_{2} \mathrm{O}: \mathrm{Na}_{2} \mathrm{O}$ ratios. The six circles for Upper Cambrian Franconian strata on figure 7 include one analysis by Berg (1952) for the Franconia Formation in Minnesota and five analyses of Upper Cambrian strata of the present study from table 1. Points on figure 7 for the Precambrian Dripping Spring Quartzite in Arizona are from Nutt (1981). For Ordovician samples, two are from Minnesota and Wisconsin (Gruner and Thiel, 1937; Woodard, 1972). Five points for Ordovician strata in New York (fig. 7) are from data obtained on insoluble residues (Braun and Friedman, 1969, table 2). It is noteworthy that even the most potassium-rich illites studied by Weaver (1967) have a maximum $\mathrm{K}_{2} \mathrm{O}: \mathrm{Na}_{2} \mathrm{O}$ ratio of about 7 and a maximum $\mathrm{K}_{2} \mathrm{O}$ content of about 6 percent. Because of the presence of analcime (Na-rich) and other zeolites in samples consisting mainly of authigenic potassium feldspar in lacustrine basins (Sheppard and Gude, 1965), the $\mathrm{K}_{2} \mathrm{O}: \mathrm{Na}_{2} \mathrm{O}$ values are 40 or less for bulk samples. Data for these are not shown. 


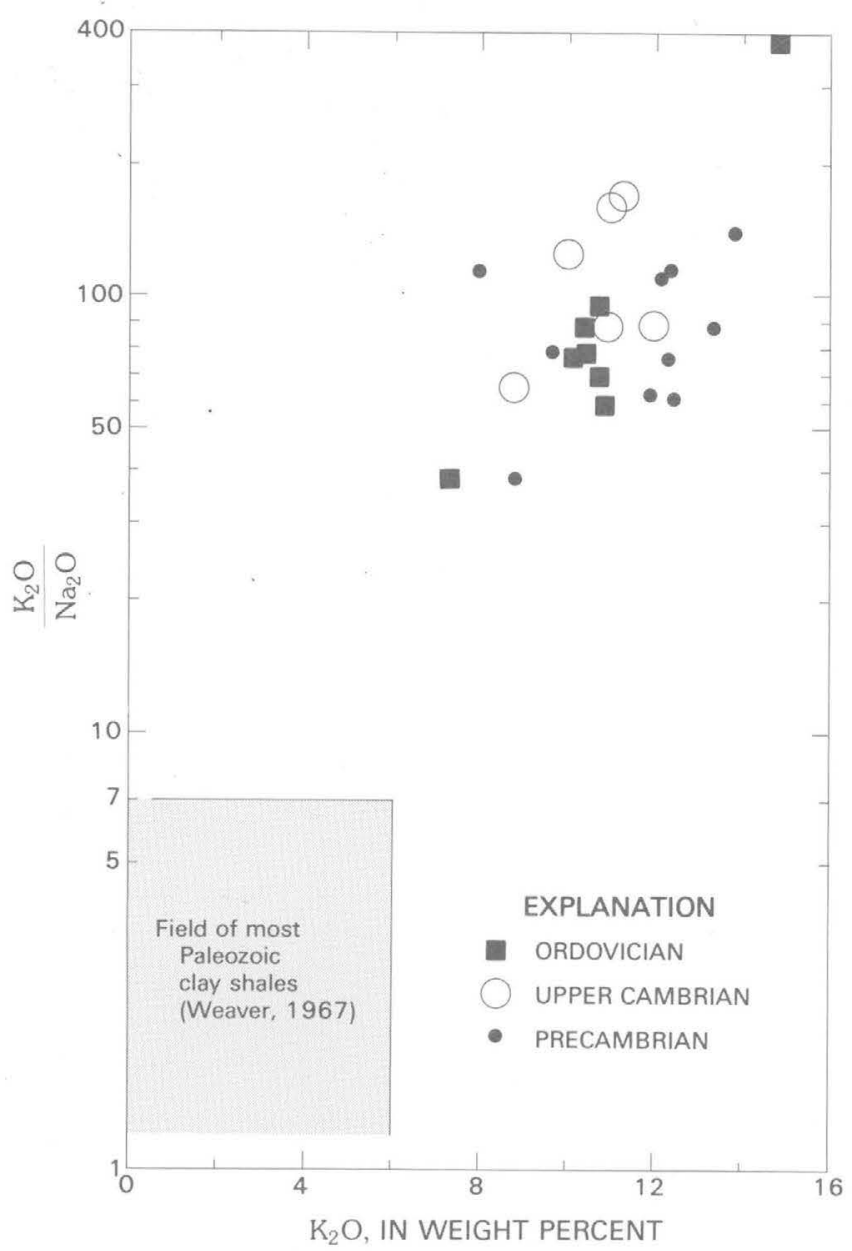

Figure 7. Concentration of $\mathrm{K}_{2} \mathrm{O}$ versus $\mathrm{K}_{2} \mathrm{O}: \mathrm{Na}_{2} \mathrm{O}$ ratio for Precambrian, Cambrian, and Ordovician authigenic-feldspathic shales and siltstones in the midcontinent and Western United States and for insoluble residues from Ordovician carbonates of New York.

Our studies by X-ray diffraction methods of either bulk samples or insoluble residues that consist mainly of authigenic potassium feldspar have the pattern of orthoclase (monoclinic potassium feldspar) for marine strata that have not been exposed to temperatures above about $150-200{ }^{\circ} \mathrm{C}$.

\section{ORIGIN OF AUTHIGENIC POTASSIUM FELDSPAR IN MARINE STRATA}

Several mechanisms have been proposed for the inplace growth of orthoclase in the Cambrian and Ordovician strata of the midcontinent region of the United States. Tester and Atwater (1934) suggested that the authigenic potassium feldspar is a normal product of consolidation and cementation in these marine strata. Gruner and Theil (1937) considered that it grew at the expense of, or during dissolution of, "clayey material." Berg
(1952) thought that detrital feldspar served as a nucleus for growth of orthoclase overgrowths, but also that authigenic crystals formed in pore spaces and filled the interstices between the detrital quartz grains. Weiss (1954) was the first proponent of an ultimate origin related to volcanic ash; he showed orthoclase replacing a brachiopod shell and believed that the host Cambrian strata were the product of feldspathization of bentonite derived from volcanic ash. Hay (1966) suggested reaction of the zeolite clinoptilolite to form potassium feldspar in Ordovician marine tuffs in Minnesota. Woodard (1972) called on direct precipitation of potassium feldspar from sea water due to high concentrations of amorphous silica. Odom (1974) believed that the material described by Woodard (1972) was the result of authigenic overgrowth on detrital feldspar and that the illite (once present) served as a major source of potassium, aluminum, and silicon.

We generally agree with Weiss (1954) that volcanic detritus was the main precursor to the development of potassium-rich beds in the lower Paleozoic marine strata of the midcontinent, and we endorse a similar origin for the Proterozoic occurrence in Arizona.

\section{REFERENCES CITED}

Barnes, V.E., and Bell, W.C., 1977, The Moore Hollow Group of central Texas: Bureau of Economic Geology Report of Investigations $88,169 \mathrm{p}$.

Berg, R.R., 1952, Feldspathized sandstone: Journal of Sedimentary Petrology, v. 22, p. 221-223.

Bowie, S.H.U., Dawson, J., Gallagher, M.J., Ostle, D., Lambert, R. St. J., and Lawson, R.I., 1966, Potassiumrich sediments in the Cambrian of northwest Scotland: Transactions Institute of Mining Metallurgy, v. 75, p. B125-B145.

Braun, Moshe, and Friedman, G.M., 1969, Carbonate lithofacies and environments of the Tribes Hill Formation (Lower Ordovician) of the Mohawk Valley, New York: Journal of Sedimentary Petrology, v. 39, p. 113-135.

Buyce, M.R., and Friedman, G.M., 1975, Authigenic K-feldspar on the Proto-Atlantic shelf: Journal of Sedimentary Petrology, v. 45, p. 808-821.

Connor, J.J., and Ebens, R.J., 1980, Geochemistry of bedrock units in Missouri and parts of adjacent states: U.S. Geological Survey Professional Paper 954-F, p. F1-F55.

Granger, H.C., and Raup, R.B., 1964, Stratigraphy of the Dripping Spring Quartzite, southeastern Arizona: U.S. Geological Survey Bulletin 1168, 119 p.

Gruner, J.W., and Theil, G.A., 1937, The occurrence of fine grained authigenic feldspar in shales and silts: American Mineralogist, v. 22, p. 842-846.

Hay, R.L., 1966, Zeolites and zeolitic reactions in sedimentary rocks: Geological Society of America Special Paper 85, $130 \mathrm{p}$.

Kurtz, V.E., 1975, Franconian (Upper Cambrian) trilobite faunas from the Elvins Group of southeastern Missouri: Journal of Paleontology, v. 49, no 6, p. 1009-1043. 
Martin, R.F., 1971, Disordered authigenic feldspars of the series $\mathrm{KAlSi}_{3} \mathrm{O}_{8}-\mathrm{KBSi}_{3} \mathrm{O}_{8}$ from southern California: American Mineralogist, v. 56, p. 281-291.

Nutt, C.J., 1981, A model of uranium mineralization in the Dripping Spring Quartzite, Gila County, Arizona: U.S. Geological Survey Open-File Report 81-524, 49 p.

Odom, I.E., 1974, Syngenetic sanidine beds from Middle Ordovician St. Peter sandstone, Wisconsin-A discussion: Journal of Geology, v. 82, p. 112-116.

Pratt, W.P., Odland, S.K., Hubert, A.E., Siems, D.F., and Viets, J.G., 1980, Spectrographic and chemical analyses of exposed Precambrian rocks, Rolla $1^{\circ}$ by $2^{\circ}$ quadrangle, Missouri: U.S. Geological Survey Open-File Report 80-25, $26 \mathrm{p}$.

Sheppard, R.A., and Gude, A.J., 3rd, 1965, Potash feldspar of possible economic value in the Barstow Formation, San Bernardino County, California: U.S. Geological Survey Circular 500, 7 p.

1973, Boron-bearing potassium feldspar of authigenic origin in closed-basin deposits: U.S. Geological Survey Journal of Research, v. 1, p. 377-382.
Tester, A.C., and Atwater, G.I., 1934, The occurrence of authigenic feldspars in sediments: Journal of Sedimentary Petrology, v. 4, p. 23-31.

Thacker, J.L., and Anderson, K.H., 1979a, Preliminary isopach and sand/shale ratios of the Cambrian Davis Formation, Rolla $1^{\circ}$ by $2^{\circ}$ quadrangle, Missouri: U.S. Geological Survey Miscellaneous Field Studies Map MF-1002-D, scale 1:250,000.

$1979 b$, Preliminary carbonate lithofacies maps of the Cambrian Davis Formation, Rolla $1^{\circ}$ by $2^{\circ}$ quadrangle, Missouri: U.S. Geological Survey Miscellaneous Field Studies Map MF-1002-E, scale 1:250,000.

Weaver, C.E., 1967, Potassium, illite and the ocean: Geochimica et Cosmochimica Acta, v. 31, p. 2181-2196.

Weiss, M.P., 1954, Feldspathized shales from Minnesota: Journal of Sedimentary Petrology, v. 24, p. 270-274.

Woodard, H.H., 1972, Syngenetic sanidine beds from Middle Ordovician Saint Peter sandstone, Wisconsin: Journal of Geology, v. 80, p. 323-332.

1974, Syngenetic sanidine beds from Middle Ordovician Saint Peter sandstone-A reply: Journal of Geology, v. 82, p. 116-119. 
Chapter B

Distribution, Petrology, and Mineral Potential of Peraluminous

Granitoid Plutons in the Eastern and Southeastern Arabian Shield, Kingdom of Saudi Arabia

\author{
By EDWARD A. DU BRAY
}

A description of the fundamental characteristics, including mineral resource potential, of 13 peraluminous granite plutons in the eastern and southeastern Arabian Shield

U.S. GEOLOGICAL SURVEY BULLETIN 1694

CONTRIBUTIONS TO MINERAL RESOURCES RESEARCH， 1984 


\title{
CONTENTS
}

\author{
Abstract 15 \\ Introduction 15 \\ Acknowledgments 16 \\ Age and setting 17 \\ Petrography 17 \\ Compositional and textural features 17 \\ Characteristic minerals 19 \\ Muscovite and Fe-Li mica 19 \\ Biotite 19 \\ Garnet 19 \\ Geochemistry 20 \\ Garnets 20 \\ Muscovite and Fe-Li mica 22 \\ Major elements 22 \\ Trace elements 22 \\ Isotopes $\mathbf{2 6}$ \\ Mineral deposit potential 27 \\ Petrogenesis 28 \\ Conclusions $\mathbf{3 0}$ \\ References cited $\mathbf{3 0}$
}

\section{FIGURES}

1. Map showing locations of peraluminous plutons in eastern and southeastern Arabian Shield 16

2. Ternary diagram showing average modal compositions for 13 peraluminous plutons in eastern and southeastern Arabian Shield 19

3. Graph showing composition of analyzed micas in terms of $\mathrm{Si}, \mathrm{Al}$, and octahedral cations (Fe, $\mathrm{Mg}, \mathrm{Ti}, \mathrm{Mn}) \mathbf{2 2}$

4. Harker diagrams showing selected major element-oxide data for samples from the peraluminous plutons 23

5. Ternary ACF diagram showing average compositions of the peraluminous plutons 23

6. Ternary diagram showing average proportions of normative quartz, albite, and orthoclase in the peraluminous plutons 23

7. Trace-element variation diagrams for the peraluminous plutons $\mathbf{2 6}$

\section{TABLES}

1. Petrographic characteristics of peraluminous granitoid plutons in eastern and southeastern Arabian Shield 18

2. Electron microprobe analyses of garnets from three peraluminous plutons in eastern and southeastern Arabian Shield 20

3. Electron microprobe analyses of micas from three peraluminous plutons in eastern and southeastern Arabian Shield 21

4. Average major-element, trace-element, and CIPW compositions for peraluminous plutons in eastern and southeastern Arabian Shield 24 


\section{Distribution, Petrology, and Mineral Potential of Peraluminous Granitoid Plutons in the Eastern and Southeastern Arabian Shield, Kingdom of Saudi Arabia}

\author{
By Edward A. du Bray
}

\begin{abstract}
Thirteen peraluminous granitoid plutons in the eastern and southeastern Arabian Shield constitute a suite that resembles metallogenically specialized or S-type granites. Most of these plutons are about $15 \mathrm{~km}^{2}$ in areal extent, but several are as large as $75 \mathrm{~km}^{2}$. Preliminary geochemical results indicate that the plutons contain anomalous concentrations of tin, tungsten, and other rare metals. Because of their ore deposit potential, these plutons warrant significantly more study.

The plutons are composed of medium-grained, leucocratic two-feldspar (nonperthitic microcline and albite) granite and granodiorite, both having hypidiomorphic- to xenomorphic-inequigranular textures. Biotite and muscovite or Fe-Li mica are present in varying proportions. Almandinespessartine garnet (as much as 1 modal percent) is present in seven of the plutons. Zircon, apatite, ilmenite, topaz, and fluorite are the characteristic accessory minerals.

The major-element chemistry of these plutons is distinctive relative to other granitoid rocks, in that they contain more than 72 weight percent $\mathrm{SiO}_{2}$ and low total iron, $\mathrm{CaO}$, and $\mathrm{MgO}$ and have a peraluminous index (molar $\mathrm{Al}_{2} \mathrm{O}_{3}$ I $\left(\mathrm{Na}_{2} \mathrm{O}+\mathrm{CaO}\right)$ ) approaching or greater than 1.0. In addition, the incompatible trace elements $\mathrm{Be}, \mathrm{Pb}, \mathrm{Sn}, \mathrm{Li}, \mathrm{F}, \mathrm{Rb}, \mathrm{Y}$, and $\mathrm{Nb}$ are significantly enriched in most of these plutons, whereas the compatible elements $\mathrm{Ba}, \mathrm{Cu}, \mathrm{La}, \mathrm{Sr}$, and $\mathrm{Zr}$ are depleted relative to global averages for granites.

Common lead isotope data suggest that most of these plutons include a component generated by partial melting of preexisting continental crust. Major-element chemical and petrographic data are consistent with crystallization of these plutons under conditions of $\mathrm{P}_{\mathrm{H}_{2} \mathrm{O}}=200-400$ megapascals (2-4 kilobars). Varying degrees of incompatible-element enrichment and compatible-element depletion among the peraluminous plutons indicate that they were derived from compositionally dissimilar source terranes. Minimum melting of four compositionally distinct source terranes could produce the trace-element variation observed in the 13 plutons.
\end{abstract}

\section{INTRODUCTION}

Geologic investigations conducted throughout the world have defined a set of petrologically similar granitoid rocks (Streckeisen, 1976) known variously as S-type, ilmenite-series, peraluminous, or metallogenically specialized granites; these categories overlap in part. S-type granites (Chappell and White, 1974) are characterized by

relatively low $\mathrm{Na}_{2} \mathrm{O}$ content, greater than 1 percent CIPW normative corundum, initial ${ }^{87} \mathrm{Sr} /{ }^{86} \mathrm{Sr}$ ratios greater than 0.708 ,

high silica content, irregular interelement variation within plutons, and the presence of muscovite or other peraluminous minerals.

In comparison, I-type granites (Chappell and White, 1974) are characterized by

relatively high $\mathrm{Na}_{2} \mathrm{O}$ content,

less than 1 percent CIPW normative corundum, initial ${ }^{87} \mathrm{Sr} /{ }^{86} \mathrm{Sr}$ ratios in the range $0.704-0.706$, broad compositional range, regular interelement variation within plutons, and, commonly, the presence of hornblende.

Ishihara (1977) has divided granitoid rocks into the magnetite series and the ilmenite series. Magnetite-series granitoid rocks contain easily recognizable magnetite and many are similar to I-type granites, whereas ilmeniteseries granitoid rocks contain ilmenite but are practically free of opaque oxide minerals (less than 0.1 volume percent) and many are similar to S-type granites. Granites are peraluminous (Shand, 1949) when the peraluminous index, molar $\left(\mathrm{Al}_{2} \mathrm{O}_{3} /\left(\mathrm{CaO}+\mathrm{Na}_{2} \mathrm{O}+\mathrm{K}_{2} \mathrm{O}\right)\right)$, exceeds 1 . Metallogenically specialized granites are characterized by incompatible-element (Cox and others, 1979, p. 336; Be, $\mathrm{Li}, \mathrm{F}, \mathrm{Pb}, \mathrm{Rb}, \mathrm{Y}$, and $\mathrm{Nb}$ ) enrichment relative to global granite averages, compatible-element ( $\mathrm{Sr}, \mathrm{Ba}, \mathrm{Zr}$, and $\mathrm{La}$ ) depletion, the presence of muscovite, and a high silica content; and many of these granites are peraluminous (Tischendorf, 1977).

S-type, ilmenite-series, and some peraluminous and metallogenically specialized granitoid rocks were derived from a source terrane that has undergone previous chemical fractionation, and they may represent partial melt 
products from sedimentary or evolved igneous rocks. Itype, magnetite-series, and nonmetallogenically specialized granitoid rocks are principally first-stage melts generated from primitive material, and they have had little if any interaction with the continental crust. S-type, ilmenite-series, peraluminous, and metallogenically specialized granitoid rocks share many characteristic features. Most of these rocks, similar to those discussed here, contain muscovite, but their most significant shared trait from the viewpoint of economic geology is their frequent association with deposits of tin and tungsten. The association of ore deposits with these rocks has generated considerable interest in their genesis and distribution throughout the world.

The present study area was defined by a reconnaissance geochemical exploration of the eastern and southeastern Proterozoic Arabian Shield (du Bray and others, 1982). Thirteen peraluminous, metallogenically specialized plutons were identified (fig. 1) that strongly resemble highly evolved plutons located elsewhere in the world that are associated with tin, tungsten, and raremetal deposits. The Arabian Shield is already known for its peralkaline granites (agpaitic index, molar $\left(\mathrm{K}_{2} \mathrm{O}+\mathrm{Na}_{2} \mathrm{O}\right) / \mathrm{Al}_{2} \mathrm{O}_{3}>1$ ) (Drysdall, 1979; Stoeser and Elliott, 1980). However, both peraluminous and peralkaline plutons are volumetrically minor relative to the vast number of calc-alkaline plutons that constitute about 40 percent of the Arabian Shield.

Geoscientists working elsewhere in the Arabian Shield have reported muscovite-bearing plutons. Elliott (1980, 1983), who studied the Gaharra alkali-feldspar granite, was perhaps first to realize the significance of muscovite-bearing plutons. Cole and others (1981) identified a muscovite-bearing stock in the northeastern Arabian Shield that contains tungsten- and tin-mineralized rock. Stacey and others (1983) reported muscovitebearing phases in the Ad Dawadimi batholith, located in the central Arabian Shield, northwest of the study area. Stoeser (1983) reported muscovite with and without garnet in several trondhjemitic plutons located in the southern Arabian Shield, and Sable (1982) discussed two muscovite-bearing monzogranites that crop out close to the Saudi Arabian-North Yemen border.

\section{Acknowledgments}

The work on which this report is based was performed in accordance with a work agreement between the U.S. Geological Survey (USGS) and the Saudi Arabian Ministry of Petroleum and Mineral Resources. D.B. Stoeser (USGS) performed microprobe analyses of the garnets, and Jane Hammarstrom (USGS) performed microprobe analyses of the micas. J.E. Quick, J.S. Pallister, and J.S. Stuckless (all of USGS), and C.R.

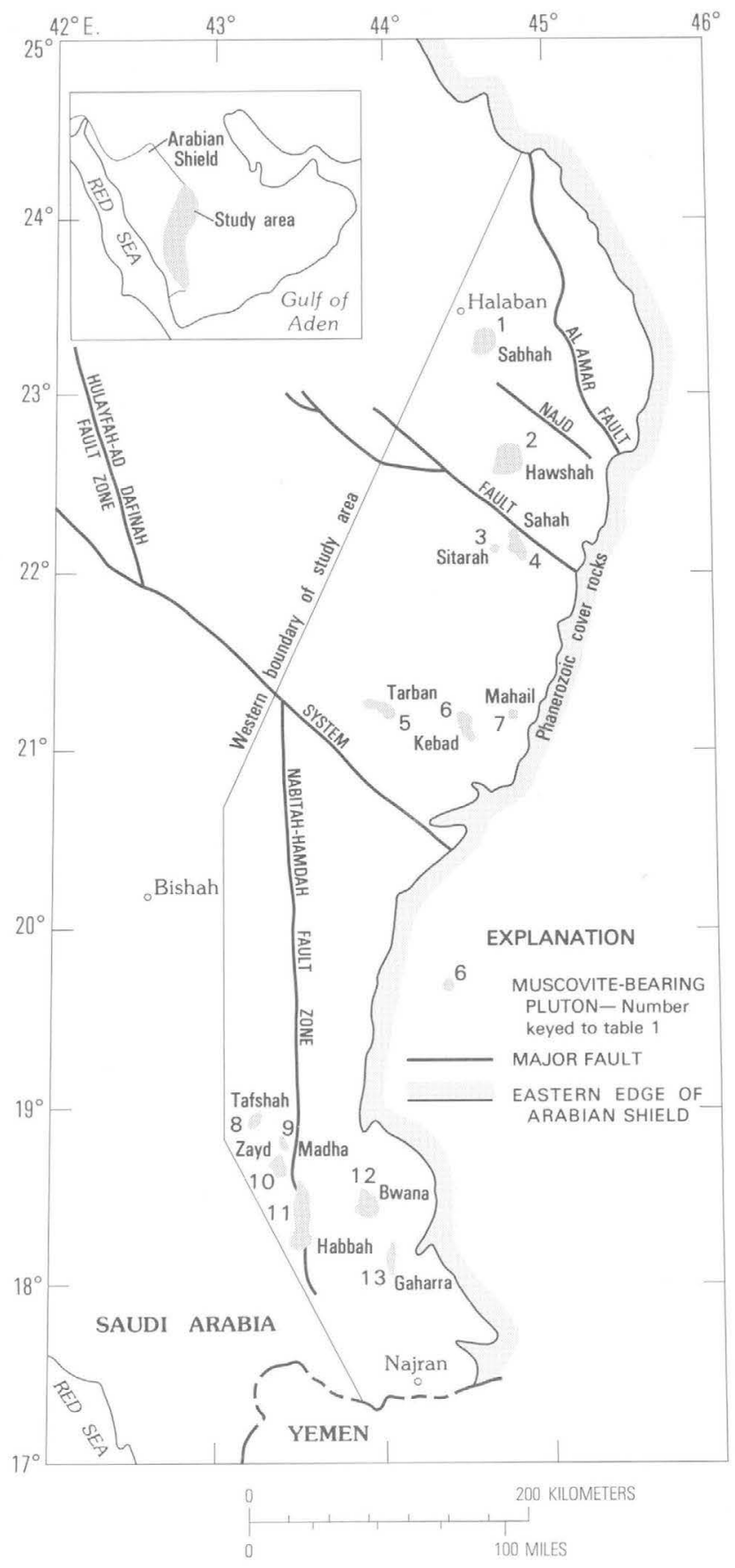

Figure 1. Locations of peraluminous plutons in the eastern and southeastern Arabian Shield. Numbers and names keyed to table 1. Plutons numbered 8-11 constitute the Madha assemblage.

Ramsey (Saudi Arabian Directorate General of Mineral Resources) provided careful reviews of the manuscript. All modal analyses were conducted by Ali Mohammed Jabarti. The paper benefited greatly from discussions with D.B. Stoeser, J.E. Quick, J.S. Pallister, and C.R. Ramsay. 


\section{AGE AND SETTING}

The peraluminous granitoid rocks appear to be among the youngest plutonic rocks exposed in the Proterozoic Arabian Shield. They intrude andesitic and dacitic volcanic and volcaniclastic rocks and molasse of the Halaban and Murdama groups, respectively. Layered rocks assigned to the Halaban group, intruded by coeval dioritic rocks, were deposited between 800 and $700 \mathrm{Ma}$ and are thought to be part of ensimatic-arc terranes that were successively accreted to the Arabian plate during its cratonization (Greenwood, Anderson, and others, 1980; Greenwood, Stoeser, and others, 1982). Rocks of the Murdama group, intruded by batholiths composed of granite, granodiorite, and tonalite, were deposited following accretionary events at a time coincident with the beginning of a collisional event, approximately $670 \mathrm{Ma}$ (Schmidt and others, 1979; Greenwood, Anderson, and others, 1980; Greenwood, Stoeser, and others, 1982; Stacey and Stoeser, 1983). Rocks of the Murdama and Halaban groups were metamorphosed at greenschist- and amphibolite-facies conditions during pluton emplacement and have been deformed several times. No genetic relationship between the peraluminous plutons and rocks of the Halaban and Murdama groups is apparent.

The 13 peraluminous plutons in the study area (fig. 1) are between 3 and $75 \mathrm{~km}^{2}$ in areal extent; the average area is about $15 \mathrm{~km}^{2}$. The outcrop patterns of the plutons range from circular to smoothly elliptical. The shapes of the plutons, their intrusive relationships, and the fact that they are free of postcrystallization deformational features suggest that they represent small, postorogenic, diapirically emplaced intrusions.

Geochronologic data also indicate that the plutons were emplaced late during the development of the Arabian Shield. Zircon separated from the Sabhah and Sitarah monzogranites and from the Madha granodiorite and dated by the $\mathrm{U} / \mathrm{Pb}$ zircon method indicates ages of $605 \pm 5$ m.y. (Stacey and others, 1983), $627 \pm 30$ m.y. (J.S. Stacey, oral commun., 1983), and $670 \pm 5$ m.y. (Stoeser and Stacey, 1983), respectively.

The peraluminous plutons of the eastern and southeastern Arabian Shield are in an intracratonic setting, similar to that of the muscovite-bearing granites that crop out in Western North America (Miller and Bradfish, 1980). The latter plutons are located near the inferred edge of Proterozoic crust, in an area that was intensely deformed coincident with and immediately preceding their emplacement. Likewise, the peraluminous plutons in the eastern and southeastern Arabian Shield are located in an orogenic zone, and their emplacement followed a hypothesized collision between the Arabian plate and an unknown terrane to the east, at a time coincident with the Pan-African thermotectonic event (Clifford, 1970). The Hulayfah-Ad Dafinah and Nabitah-Hamdah fault zones (to be referred to collectively as the HNFZ) (fig. 1), along which are numerous outcrops of ultramafic rocks, are the inferred sutures; and the area affected by the collision was probably a broad zone that encompassed the peraluminous plutons (Schmidt and others, 1979; Schmidt and Brown, 1982; Stoeser and others, 1982).

The 13 plutons are in two geographic assemblages. One assemblage includes seven plutons in the northern part of the study area (plutons 1-7, fig. 1, table 1), and the other assemblage of six is located about $400 \mathrm{~km}$ to the south. For the sake of later discussion, four of the plutons in this latter assemblage (plutons 8-11, along or west of the HNFZ; fig. 1, table 1) are called the Madha assemblage plutons.

Plutons 1, 2, 4, and 6-13 do not contain xenoliths of either wall rock or refractory residuum. Plutons 3 and 5 have locally stoped and engulfed large blocks of wall rock, but there is no indication of chemical interaction between these blocks and the enclosing rock, nor between the other non-Madha assemblage plutons and the enclosing wall rock. Plutons of the Madha assemblage, however, are characterized by localized mafic schlieren layering, which suggests interaction with wall rock, possibly including its partial assimilation.

\section{PETROGRAPHY}

\section{Compositional and Textural Features}

Most of the peraluminous plutons of the eastern and southeastern Arabian Shield are alaskitic alkalifeldspar granites, although some samples are syenogranitic, granodioritic, or trondhjemitic. Most of these plutons are medium grained, hypidiomorphic to xenomorphic granular, and inequigranular seriate to equigranular, although some are subporphyritic. The hypidiomorphic inequigranular texture that characterized most of these rocks indicates simultaneous crystallization of the feldspars and quartz. The petrographic features of these plutons are summarized in table 1 , and modal data, obtained by counting between 400 and 700 points on stained slabs averaging $60 \mathrm{~cm}^{2}$ of surface area, are summarized on figure 2 .

The modal compositions of plutons $1,3-7$, and 12-13 cluster in the alkali-feldspar granite field (fig. 2). Modes for plutons 2 and 8 plot in the monzogranite field. Plutons 9-11 of the Madha assemblage are distinctly more granodioritic than the remaining plutons.

Most samples contain subequal amounts of quartz, plagioclase, and potassium feldspar, and from 0 to 5 percent mafic silicate minerals (although the Madha assemblage plutons contain significantly more plagioclase). The potassium feldspar is microcline characterized by gridiron twinning and is amazonitic in some 
Table 1. Petrographic characteristics of peraluminous granitoid plutons in eastern and southeastern Arabian Shield

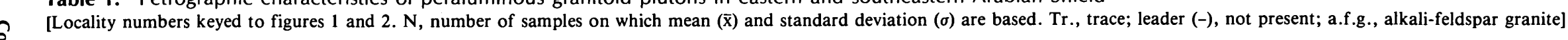

\begin{tabular}{|c|c|c|c|c|c|c|c|c|c|c|c|c|c|c|c|}
\hline \multirow{2}{*}{\multicolumn{2}{|c|}{$\begin{array}{l}\text { Locality number } \\
\text { and pluton }\end{array}$}} & \multirow[t]{2}{*}{ Texture and grain size } & \multirow[t]{2}{*}{$\mathrm{N}$} & \multicolumn{2}{|c|}{ Quartz } & \multicolumn{2}{|c|}{ Microcline } & \multicolumn{4}{|c|}{$\begin{array}{l}\text { Modal minerals } \\
\text { Plagioclase Biotite }\end{array}$} & \multicolumn{2}{|c|}{$\begin{array}{c}\text { Muscovite or } \\
\mathrm{Fe}-\mathrm{Li} \text { mica }\end{array}$} & \multicolumn{2}{|c|}{ Garnet } \\
\hline & & & & $\overline{\mathrm{x}}$ & $\sigma$ & $\overline{\mathrm{x}}$ & $\sigma$ & $\overline{\mathrm{x}}$ & $\sigma$ & $\overrightarrow{\mathrm{x}}$ & $\sigma$ & \multirow{2}{*}{$\overrightarrow{\mathrm{x}}$} & \multirow{2}{*}{$\frac{\sigma}{1}$} & \multirow{2}{*}{$\overline{\bar{x}}$} & \multirow{2}{*}{$\sigma$} \\
\hline 1 & Sabhah a.f.g. & $\begin{array}{l}\text { Hypidiomorphic, inequigranular, } \\
\text { medium grained. }\end{array}$ & 15 & 33 & 3 & 33 & 3 & 30 & 4 & 3 & 1 & & & & \\
\hline 2 & $\begin{array}{l}\text { Hawshah } \\
\text { monzogranite. }\end{array}$ & $\begin{array}{l}\text { Hy pidiomorphic, inequigranular } \\
\text { to subporphyritic, medium } \\
\text { grained. }\end{array}$ & 13 & 33 & 6 & ${ }^{2} 34$ & 7 & 29 & 6 & - & - & 4 & 2 & - & - \\
\hline 3 & Sitarah a.f.g. & $\begin{array}{l}\text { Hypidiomorphic to xenomorphic, } \\
\text { inequigranular to subporphyr- } \\
\text { itic. }\end{array}$ & 30 & 33 & 7 & ${ }^{2} 35$ & 8 & 29 & 5 & - & - & 3 & 1 & - & - \\
\hline 4 & Sahah a.f.g. & $\begin{array}{l}\text { Hypidiomorphic, equigranular, } \\
\text { medium to coarse grained. }\end{array}$ & 15 & 36 & 5 & 38 & 5 & 23 & 5 & 2 & 1 & 1 & 1 & - & - \\
\hline 5 & Tarban a.f.g. & $\begin{array}{l}\text { Hypidiomorphic to xenomorphic, } \\
\text { inequigranular, medium } \\
\text { grained. }\end{array}$ & 33 & 31 & 9 & $3_{37}$ & 7 & 30 & 8 & 1 & 2 & 1 & 1 & $\operatorname{Tr}$ & \\
\hline 6 & Kebad a.f.g. & $\begin{array}{l}\text { Hy pidiomorphic, inequigranular, } \\
\text { medium grained. }\end{array}$ & 4 & 27 & 5 & 25 & 5 & 44 & 4 & $\operatorname{Tr}$ & & 4 & 2 & $\operatorname{Tr}$ & \\
\hline 7 & Mahail a.f.g. & $\begin{array}{l}\text { Hy pidiomorphic, equigranular, } \\
\text { medium grained. }\end{array}$ & 4 & 41 & 5 & 17 & 1 & 38 & 6 & - & - & 4 & 1 & 1 & 1 \\
\hline 8 & $\begin{array}{l}\text { Tafshah } \\
\text { monzogranite. }\end{array}$ & $\begin{array}{l}\text { Hypidiomorphic, inequigranular, } \\
\text { medium grained, gneissic. }\end{array}$ & 6 & 32 & 5 & 31 & 9 & 35 & 7 & $\operatorname{Tr}$ & & 2 & 1 & 0.5 & 1 \\
\hline 9 & $\begin{array}{l}\text { Madha } \\
\text { granodiorite. }\end{array}$ & ----do-- & 5 & 29 & 10 & 13 & 5 & 53 & 11 & $\operatorname{Tr}$ & & 5 & 3 & .2 & 1 \\
\hline 10 & $\begin{array}{l}\text { Zayd } \\
\text { granodiorite. }\end{array}$ & $\begin{array}{l}\text { Hypidiomorphic, equigranular, } \\
\text { medium grained. }\end{array}$ & 9 & 30 & 6 & 21 & 7 & 48 & 8 & $\operatorname{Tr}$ & & 1 & 1 & $\operatorname{Tr}$ & \\
\hline 11 & $\begin{array}{l}\text { Habbah } \\
\text { granodiorite. }\end{array}$ & $\begin{array}{l}\text { Hypidiomorphic, inequigranular, } \\
\text { medium grained, pegmatitic. }\end{array}$ & 7 & 27 & 9 & 25 & 8 & 47 & 8 & - & - & 1 & 1 & $\operatorname{Tr}$ & \\
\hline 12 & Bwana a.f.g. & $\begin{array}{l}\text { Hypidiomorphic, inequigranular } \\
\text { to subporphyritic, medium } \\
\text { grained. }\end{array}$ & 13 & 234 & 6 & ${ }^{3} 39$ & 7 & 23 & 9 & - & - & 4 & 2 & - & - \\
\hline 13 & Gaharra a.f.g. & $\begin{array}{l}\text { Hypidiomorphic, equigranular, } \\
\text { medium grained. }\end{array}$ & 19 & 32 & 7 & 28 & 5 & 35 & 7 & $\operatorname{Tr}$ & & 5 & 3 & - & - \\
\hline
\end{tabular}

${ }^{1}$ Accessory minerals (principally fluorite, ilmenite, and zircon) are <l percent in most samples.

${ }^{2}$ Indicates subporphyritic phase.

${ }^{3}$ Amazonite. 
plutons. It is rarely perthitic, which indicates that conditions favoring subsolvus crystallization of two alkali feldspars prevailed during crystallization. The plagioclase is unzoned, polysynthetically twinned albite. Zircon, apatite, fluorite, ilmenite, and rarely topaz or cassiterite are the accessory minerals identified in these plutons.

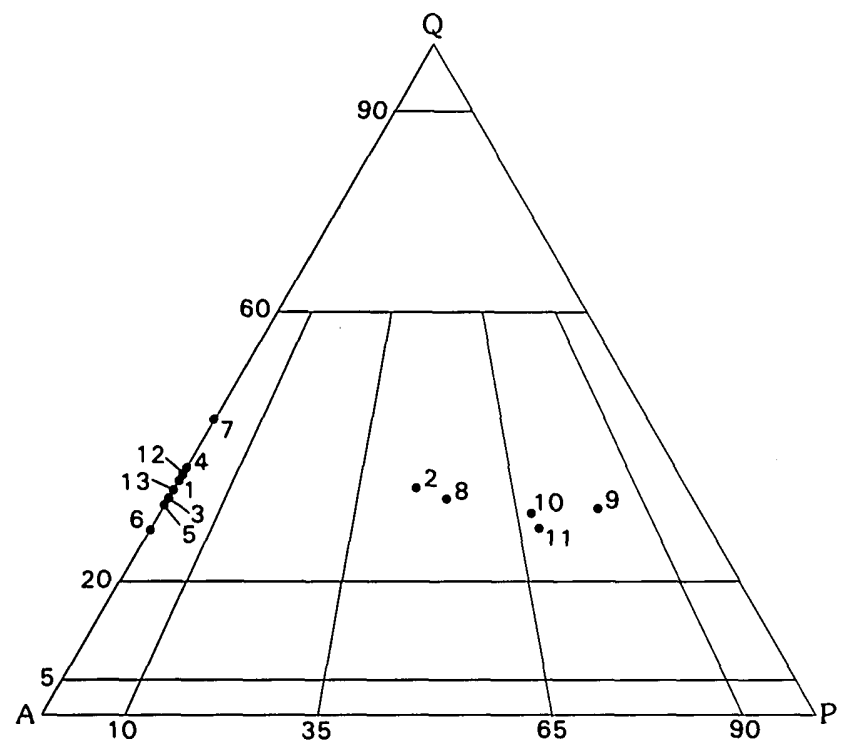

Figure 2. Ternary diagram showing average modal compositions for 13 peraluminous plutons in the eastern and southeastern Arabian Shield. Identification numbers refer to the 13 plutons; locations shown in figure 1, petrographic data in table 1. Composition boundaries after Streckeisen (1976). A, Alkali feldspar; $Q$, quartz; P, plagioclase.

\section{Characteristic Minerals}

\section{Muscovite and Fe-Li Mica}

Muscovite or Fe-Li mica is characteristic of the peraluminous plutons. It is interstitial, occurs as subhedral to anhedral flakes, and appears to have nucleated late in the crystallization process. It forms coarse intergrowths and is in textural equilibrium with biotite. Sericite is a common alteration product of plagioclase in some of the plutons but is readily distinguishable from primary micas.

Three species of primary mica were distinguished on the basis of pleochroism. The most common of these is colorless in thin section and is muscovite. This mica attains the largest average grain size $(2 \mathrm{~mm})$ and has the best crystal form of the three species observed. A second type of mica, an Fe-Li mica, identified in the Bwana alkali-feldspar granite and in the Tarban alkali-feldspar granite, is colorless to light green or slightly bluish light green. This coloration may be attributable to ferrous iron substituting for octahedrally coordinated aluminum (Deer and others, 1966, p. 203). A third type of mica, also an Fe-Li mica, occurs in samples of the Sabhah and Sitarah alkali-feldspar granites and the Hawshah monzogranite, and displays colorless to light-brown pleochroism. It typically includes numerous prismatic crystals of zircon having distinctive pleochroic halos. The pleochroic scheme and paragenesis of this mica most closely match those described for zinnwaldite. The coloration is attributable to ferric iron substituting for octahedral aluminum (Deer and others, 1966, p. 203).

Biotite

Biotite is a nearly ubiquitous constituent of the peraluminous plutons. In most samples it is subhedral to anhedral, and interstitial. In thin section it displays lightyellow to brown or reddish-brown pleochroism. Numerous included prismatic crystals of zircon characterize the biotite.

Textural relations and mineralogy suggest that a reaction relationship between garnet and biotite existed in seven of the plutons. The Mahail alkali-feldspar granite and Habbah granodiorite, both garnet bearing, contain no biotite. In the remaining five garnetiferous plutons, biotite is in textural disequilibrium and was being resorbed during the final stages of crystallization. These observations indicate that garnet crystallized at the expense of biotite in a generalized reaction such as: biotite $+\mathrm{MnO}+\mathrm{Al}_{2} \mathrm{O}_{3}+\mathrm{SiO}_{2}$ (from liquid) go to garnet + muscovite. This reaction was first proposed by Miller and Stoddard (1981) for the paragenesis of garnets observed in leucogranites from the Old Woman-Piute Range in southern California.

\section{Garnet}

Small, subhedral grains of apparently unzoned garnet, from 0.10 to $0.50 \mathrm{~mm}$ in diameter, were identified in seven of the plutons in amounts of as much as 1 modal percent (table 1). The garnet has a remarkably similar appearance from one pluton to the next. Completely isotropic almandine-spessartine garnet forms light-rosecolored grains containing few inclusions. The garnets show no sign of resorption or alteration; however, a reaction between adjacent grains of garnet and biotite, involving the growth of garnet at the expense of biotite, is commonly observed. The petrographic observations suggest that the garnets nucleated from a silicate melt. Garnet-bearing samples and plutons containing more than 0.1 weight percent $\mathrm{MnO}$ are positively correlated (tables 1-3). 


\section{Geochemistry}

Garnets

Major-element analyses of garnet from three of the peraluminous plutons were obtained by using an electron microprobe (table 2). The garnets analyzed are mixtures of the almandine, spessartine, and pyrope end members.
Garnets from the Mahail alkali-feldspar granite and the Tafshah monzogranite are almandine rich, whereas garnets from the Madha granodiorite contain approximately equal proportions of almandine and spessartine and are substantially enriched in the pyrope component relative to garnets from the other two plutons.

Chemical zoning in the garnets is difficult to demonstrate. Results of analyses made at the core and

Table 2. Electron microprobe analyses of garnets from three peraluminous plutons in eastern and southeastern Arabian Shield

[Analyses performed using an automated, six-spectrometer electron probe microanalyzer at U.S. Geological Survey, Denver, Colo. All analyses made using a focused 5- $\mu \mathrm{m}$ beam. Number in parentheses following core/rim designation, number of grains analyzed. Mean and standard deviation $( \pm)$ are listed in cases where more than one grain was analyzed. Leader (-), nil amount; a.f.g., alkali-feldspar granite]

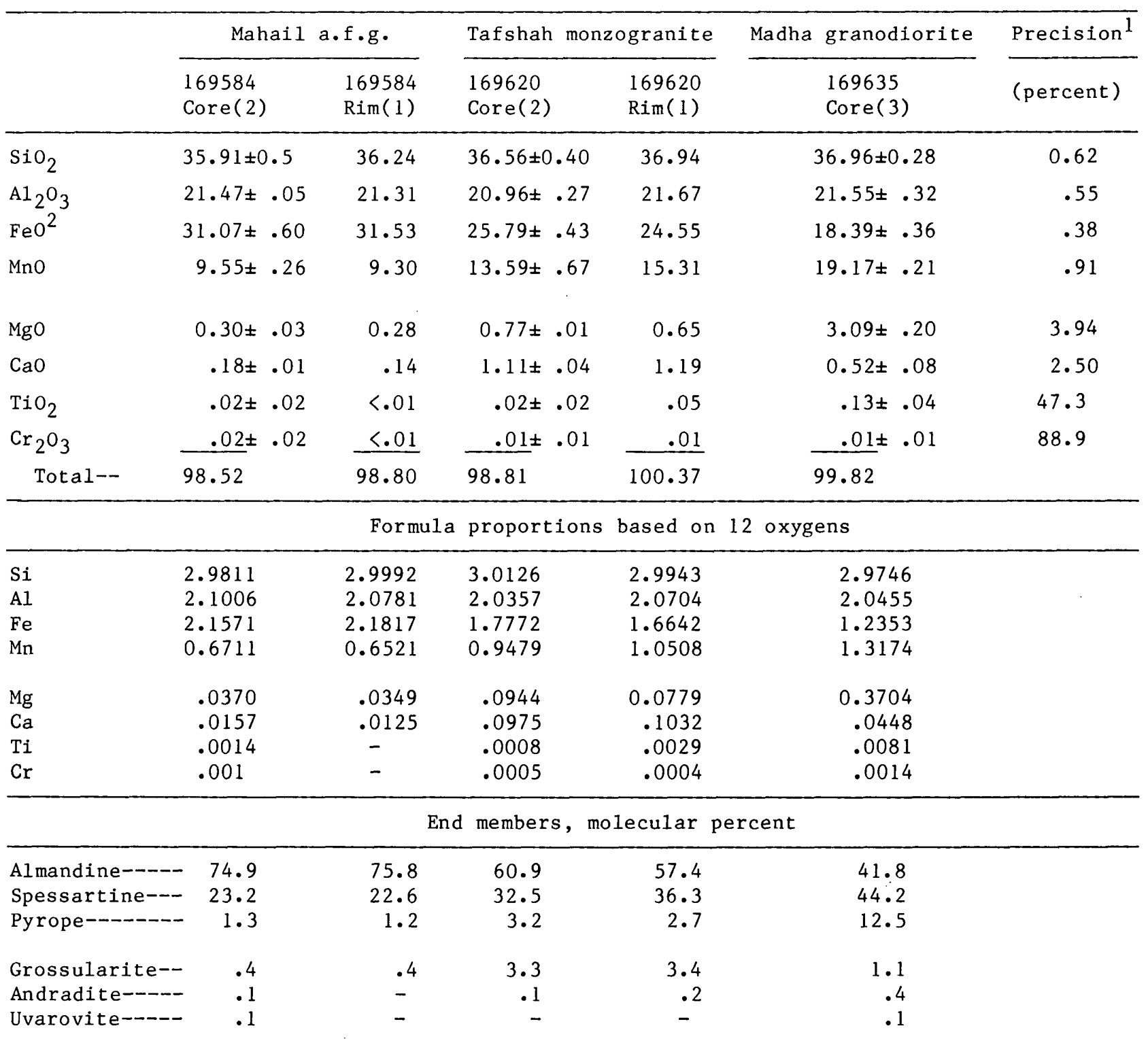

\footnotetext{
${ }^{1}$ Analytical precision based on counting statistics given in percent of amount indicated.

${ }^{2}$ Total iron as FeO.
} 
the rim of garnets from the Mahail alkali-feldspar granite are very similar, probably within the limits of analytical uncertainty. Some small variation between the rim and core of garnets from the Tafshah monzogranite is suggested. The results suggest that the core is enriched in the almandine and pyrope components relative to the rim and that the rim is enriched in the spessartine component relative to the core.

Table 3. Electron microprobe analyses of micas from three peraluminous plutons in eastern and southeastern Arabian Shield

[Analyses performed using an automated, six-spectrometer electron probe microanalyzer at U.S. Geological Survey, Reston, Va. All analyses made using a defocused $10-15-\mu \mathrm{m}$ beam. Number following grain number (Gr.), number of analyses per grain. Mean and standard deviation $( \pm)$ listed when more than one grain analysis was performed. Leader (-), nil amount; a.f.g., alkali-feldspar granite]

\begin{tabular}{|c|c|c|c|c|c|c|c|}
\hline & \multicolumn{3}{|c|}{$\begin{array}{c}\text { Sabhah a.f.g. } \\
169438\end{array}$} & \multicolumn{2}{|c|}{$\begin{array}{c}\text { Bwana a.f.g } \\
169625\end{array}$} & $\begin{array}{c}\text { Habbaah } \\
\text { granodiorite } \\
169609\end{array}$ & \multirow{2}{*}{$\frac{\text { Precision }^{1}}{(\text { percent })}$} \\
\hline & Gr. $1(3)$ & Gr. 2(1) & Gr. 3(3) & Gr. $1(3)$ & Gr. 2(2) & Gr. 1 (3) & \\
\hline $\mathrm{SiO}_{2}$ & $36.71 \pm 0.39$ & 35.73 & $36.67 \pm 0.52$ & $38.69 \pm 2.40$ & $42.86 \pm 0.04$ & $45.20 \pm 0.29$ & 1.44 \\
\hline $\mathrm{Al}_{2} \mathrm{O}_{3}$ & $21.59 \pm .03$ & 21.48 & $21.55 \pm .28$ & $21.49 \pm 1.64$ & $22.24 \pm .21$ & $43.06 \pm .18$ & 0.78 \\
\hline${ }^{2} \mathrm{FeO}$ & $22.51 \pm .42$ & 24.74 & $24.23 \pm 1.09$ & $17.51 \pm 3.22$ & $16.38 \pm .06$ & $4.98 \pm .36$ & 1.33 \\
\hline MgO & $0.07 \pm .01$ & 0.07 & $0.09 \pm .01$ & $0.08 \pm .02$ & $0.08 \pm .01$ & $1.24 \pm .10$ & 19.52 \\
\hline $\mathrm{CaO}$ & $.06 \pm .02$ & .04 & $.09 \pm .02$ & $.04 \pm .01$ & $.02 \pm .01$ & $0.01-$ & 31.14 \\
\hline $\mathrm{Na}_{2} \mathrm{O}$ & $.28 \pm .02$ & .19 & $.25 \pm .01$ & $.29 \pm .01$ & $.22 \pm .01$ & $.30 \pm .04$ & 4.87 \\
\hline $\mathrm{K}_{2} \mathrm{O}$ & $9.29 \pm .05$ & 9.24 & $9.41 \pm .11$ & $9.09 \pm .23$ & $10.02 \pm .17$ & $10.90 \pm .08$ & 1.86 \\
\hline $\mathrm{TiO}_{2}$ & $.23 \pm .05$ & .23 & $.21 \pm .01$ & $.10 \pm .02$ & $.14 \quad-$ & $.47 \pm .01$ & 16.92 \\
\hline MnO & $.58 \pm .03$ & .63 & $.63 \pm .01$ & $.99 \pm .18$ & $.98 \pm .01$ & $.05 \pm .02$ & 3.66 \\
\hline $\mathrm{BaO}$ & $.04 \pm .04$ & - & $.05 \pm .04$ & $.09 \pm .03$ & $.09 \pm .01$ & $.25 \pm .03$ & 39.92 \\
\hline $\mathrm{Cl}$ & $.09 \pm .02$ & .09 & $.08 \pm .02$ & $.03 \pm .02$ & $.03-$ & - & 26.79 \\
\hline$F^{2}$ & $3.49 \pm .18$ & 3.43 & $3.28 \pm .16$ & $4.08 \pm .17$ & $4.02 \pm .21$ & $.19 \pm .14$ & 6.25 \\
\hline${ }^{3} \mathrm{H}_{2} \mathrm{O}$ & $2.07 \pm .05$ & 2.09 & $2.21 \pm .06$ & $1.80 \pm .21$ & $2.09 \pm .12$ & $4.30 \pm .08$ & \\
\hline Total ${ }^{4}$ & 95.53 & 96.51 & 97.35 & 92.55 & 97.43 & 99.48 & \\
\hline \multicolumn{8}{|c|}{ Formula proportions based on $12(\mathrm{O}, \mathrm{OH}, \mathrm{F})$} \\
\hline $\begin{array}{l}\mathrm{Si} \\
\mathrm{Al} \\
\mathrm{Al} \\
\mathrm{Fe} \\
\mathrm{Mg}\end{array}$ & $\begin{array}{r}2.93 \\
1.07 \\
.97 \\
1.50 \\
.01\end{array}$ & $\begin{array}{r}2.86 \\
1.14 \\
.89 \\
1.66 \\
.01\end{array}$ & $\begin{array}{r}2.90 \\
1.10 \\
.91 \\
1.61 \\
.01\end{array}$ & $\begin{array}{r}3.10 \\
.90 \\
1.13 \\
1.18 \\
.01\end{array}$ & $\begin{array}{r}3.22 \\
.78 \\
1.19 \\
1.03 \\
.01\end{array}$ & $\begin{array}{r}3.08 \\
.92 \\
1.66 \\
.28 \\
.13\end{array}$ & \\
\hline $\begin{array}{l}\mathrm{Ti} \\
\mathrm{Mn} \\
\mathrm{Ca} \\
\mathrm{Na}\end{array}$ & $\begin{array}{l}.01 \\
.04 \\
- \\
.04\end{array}$ & $\begin{array}{l}.01 \\
.04 \\
- \\
.03\end{array}$ & $\begin{array}{l}.01 \\
.04 \\
.01 \\
.04\end{array}$ & $\begin{array}{l}.01 \\
.07 \\
- \\
.04\end{array}$ & $\begin{array}{l}.01 \\
.06 \\
- \\
.03\end{array}$ & $\begin{array}{l}.02 \\
- \\
.05\end{array}$ & \\
\hline $\begin{array}{l}\mathrm{K} \\
\mathrm{Ba} \\
\mathrm{F} \\
\mathrm{C}_{\mathrm{OH}}\end{array}$ & $\begin{array}{l}.95 \\
- \\
.88 \\
.01 \\
1.11\end{array}$ & $\begin{array}{l}.95 \\
- \\
.87 \\
.01 \\
1.12\end{array}$ & $\begin{array}{l}.95 \\
- \\
.82 \\
.01 \\
1.17\end{array}$ & $\begin{array}{l}.93 \\
- \\
1.04 \\
.01 \\
.96\end{array}$ & $\begin{array}{l}.96 \\
- \\
.96 \\
- \\
1.05\end{array}$ & $\begin{array}{l}.95 \\
.01 \\
.04 \\
- \\
1.96\end{array}$ & \\
\hline
\end{tabular}


Major-element analyses of micas from three of the peraluminous plutons were obtained using an electron microprobe (table 3). Sums of the oxides and of cation occupancy in the octahedral sites in samples of mica from the Sabhah and Bwana alkali-feldspar granites are low. $\mathrm{LiO}_{2}$, which may be a principal component of these micas, was not determined and may account for the low totals.

The composition of mica from the Habbah granodiorite plots in the muscovite field (fig. 3) defined by Miller and others (1981). As is characteristic of most plutonic muscovite, this mica has low contents of total $\mathrm{Fe}, \mathrm{F}$, and $\mathrm{LiO}_{2}$, and high $\mathrm{H}_{2} \mathrm{O}$ content relative to other micas (Deer and others, 1962, p. 16-18). Muscovite in the Habbah granodiorite, like mica in the Kebad, Mahail, Tafshah, Madha, and Zayd plutons, is nonpleochroic; the composition of muscovite in the Habbah granodiorite is probably representative of the mica in these plutons.

Samples of mica from the Sabhah and Bwana alkali-feldspar granites are compositionally similar to zinnwaldite. The high inferred content of $\mathrm{LiO}_{2}$, high contents of total $\mathrm{Fe}, \mathrm{MnO}$, and $\mathrm{F}$, low contents of $\mathrm{MgO}$ and $\mathrm{H}_{2} \mathrm{O}$, and intermediate content of $\mathrm{Al}_{2} \mathrm{O}_{3}$ relative to other micas are all characteristic of zinnwaldite (Deer and others, 1962, p. 93). Compared to typical zinnwaldite, however, mica from these two plutons is characterized by slightly higher occupancy in the octahedral site and by a slightly higher ratio of $\mathrm{Al}$ to $\mathrm{Si}$ (fig. 3). The pleochroism observed in mica from these two plutons is also characteristic of mica from plutons 2-5 and 13; the composition of the zinnwaldite in the Sabhah and Bwana alkali-feldspar granites is probably representative of that in plutons $2-5$ and 13 .

\section{Major Elements}

Forty-three samples of the peraluminous plutons were analyzed for their major-element composition. These analyses and analyses for 11 other samples (Delfour, 1979, 1980; Kanaan, 1979) were used to calculate the average major-element composition of each pluton (table 4, figs. 4-6). Data for the 54 samples are presented by du Bray (1983a). The $\mathrm{SiO}_{2}$ content ranges from 72 to 78 weight percent and averages 75 weight percent; the plutons are weakly to strongly peraluminous (many samples contain more than 1 percent CIPW normative corundum); total iron, $\mathrm{MgO}, \mathrm{TiO}_{2}$, and $\mathrm{CaO}$ contents are very low. These chemical characteristics are similar to those attributed to S-type granites (Chappell and White, 1974) and to metallogenically specialized granites (Tischendorf, 1977). The muscovite-bearing plutons are characterized, however, by subequal $\mathrm{Na}_{2} \mathrm{O}$ and $\mathrm{K}_{2} \mathrm{O}$ contents, whereas S-type and metallogenically

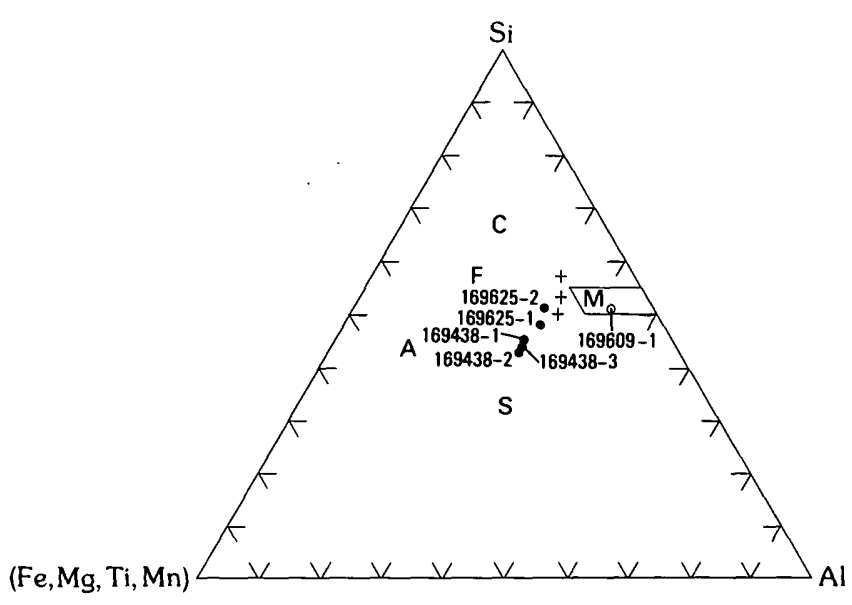

Figure 3. Composition of analyzed micas with sample and grain numbers in terms of $\mathrm{Si}, \mathrm{Al}$, and octahedral cations ( $\mathrm{Fe}$, $\mathrm{Mg}, \mathrm{Ti}, \mathrm{Mn}$ ) (modified from Miller and others, 1981). Solid circle, zinnwaldite; open circle, muscovite. Zinnwaldites of Deer and others (1962, p. 93) are plotted $(+)$, without $\mathrm{Li}_{2} \mathrm{O}$ component, for comparison. Locations of mica end-members $M$ (muscovite, fluormuscovite, and paragonite-parallelogramshaped field at right edge of triangle); $F$ (ferrimuscovite); $C$, (celadonite); A (annite-phlogopite); and S (siderophylliteeastonite) are also plotted.

specialized granites are distinctive because they contain significantly more $\mathrm{K}_{2} \mathrm{O}$ than $\mathrm{Na}_{2} \mathrm{O}$. Either different types of source terrane or different conditions of magma genesis could account for the alkali element discrepancy.

As is typical of S-type granites, the within-pluton scatter of major-element data on Harker diagrams is significant. Average oxide values were calculated for each pluton and plotted on Harker and ternary diagrams (table 4, figs. 4-6). Some between-pluton trends, however, are apparent: $\mathrm{Al}_{2} \mathrm{O}_{3}$ and $\mathrm{CaO}$ decrease and $\mathrm{K}_{2} \mathrm{O}$ increases with increasing $\mathrm{SiO}_{2} ; \mathrm{Na}_{2} \mathrm{O}$, total iron, and the peraluminous index display no consistent covariation with $\mathrm{SiO}_{2}$ content. Analyses for plutons 8-11 of the Madha assemblage plot away from or at the periphery of the data fields defined by all other plutons.

The minor-element compositions of these plutons are as follows (in weight percent): $\mathrm{TiO}_{2}$ ranges from 0 to 0.37 and averages $0.06 ; \mathrm{MnO}$ and $\mathrm{P}_{2} \mathrm{O}_{5}$ range from 0 to 0.2 and average 0.06 and 0.05 , respectively; $\mathrm{MgO}$ ranges from 0 to 0.4 and averages 0.10 ; total $\mathrm{H}_{2} \mathrm{O}$ ranges from 0 to 1.25 and averages 0.56 . None of these oxides displays a consistent covariation with $\mathrm{SiO}_{2}$.

\section{Trace Elements}

Table 4 allows comparison of the trace-element compositions of the peraluminous granites with those of metallogenically specialized granites, granites of the world, and the granitoid rocks of the eastern and southeastern Arabian Shield. Note that the trace-element compositions 

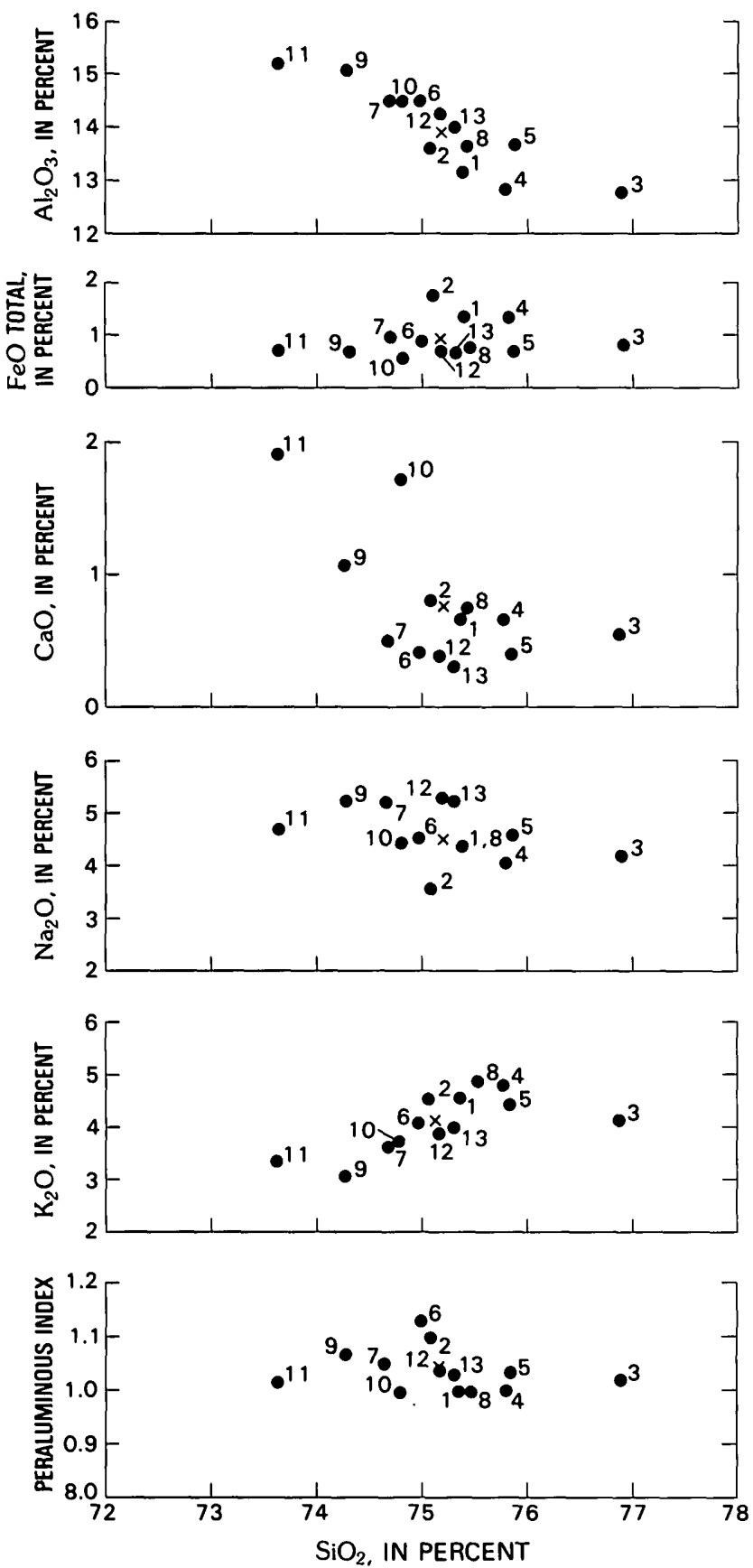

Figure 4. Harker diagrams showing selected major elementoxide data for samples from the peraluminous plutons. Plotted points represent average values for the plutons in weight percent (table 3); numbers $1-13$ refer to the plutons, whose locations are shown in figure 1 and whose petrographic characteristics are listed in table 1. $X$, average value for all 54 samples. Peraluminous index $=\mathrm{Al}_{2} \mathrm{O}_{3} /\left(\mathrm{CaO}+\mathrm{K}_{2} \mathrm{O}+\mathrm{Na}_{2} \mathrm{O}\right)$ on a molecular basis.

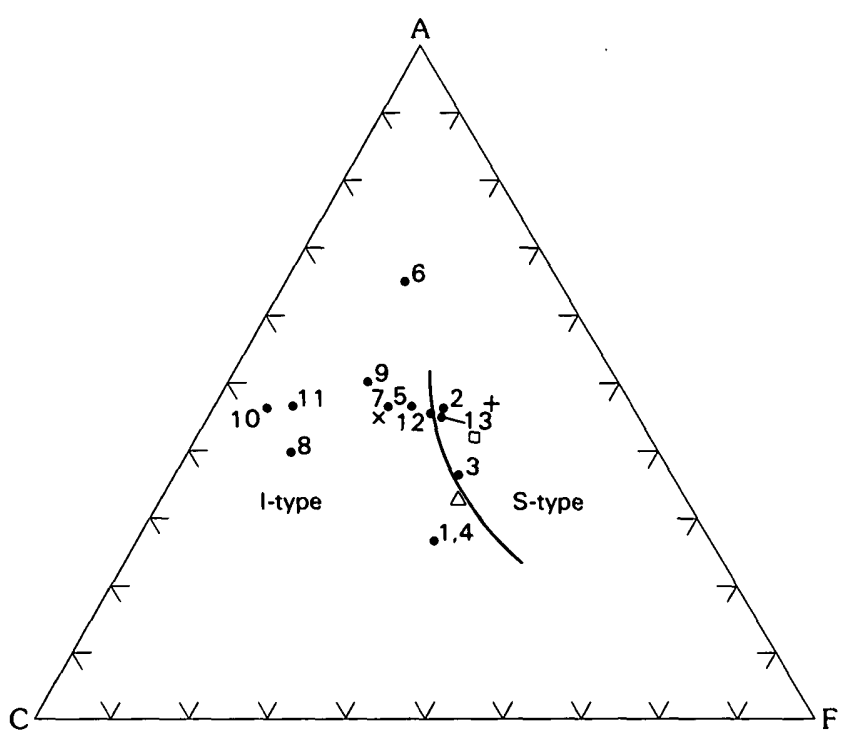

Figure 5. Ternary ACF diagram showing average compositions of the peraluminous plutons. $\mathrm{A}=\mathrm{Al}_{2} \mathrm{O}_{3}-\mathrm{Na}_{2} \mathrm{O}-\mathrm{K}_{2} \mathrm{O} ; \mathrm{C}=$ $\mathrm{CaO} ; \mathrm{F}=\mathrm{FeO}+\mathrm{MgO}$; all in molecular amounts. Pluton nos. 1-13 keyed to table 1 (petrographic characteristics) and figure 1 (map locations). Line, boundary between I- and S-type compositions, respectively, as suggested by White and Chappell (1977). X, average composition for all 54 samples; triangle, average composition of 2,327 granites (Krauskopf, 1967); + , average composition of 962 metallogenically specialized granitoids (Tischendorf, 1977); rectangle, average composition of 226 precursor granites (Tischendorf, 1977).

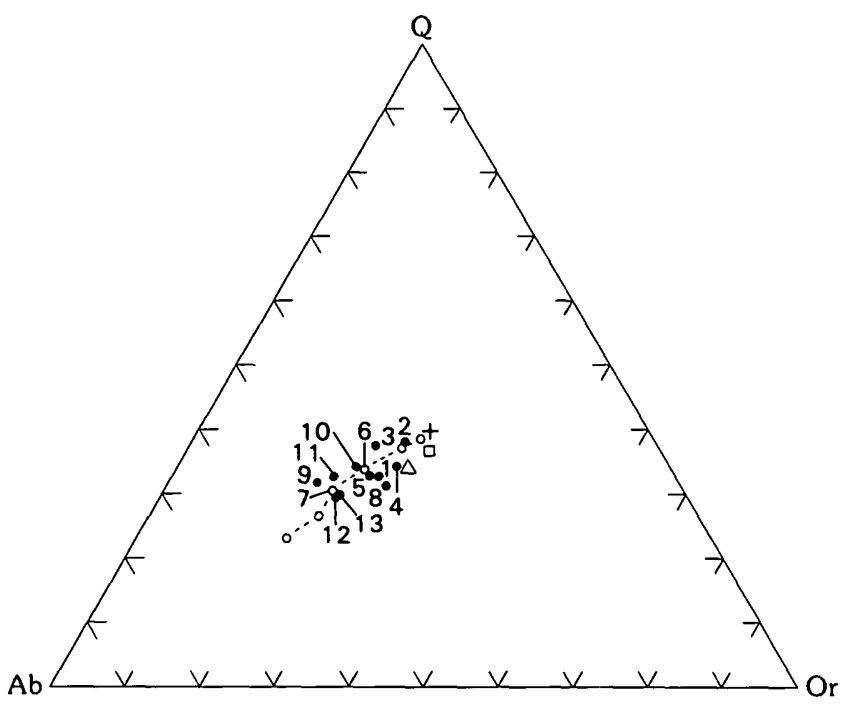

Figure 6. Ternary diagram showing average proportions of normative quartz $(\mathrm{Q})$, albite $(\mathrm{Ab})$, and orthoclase (Or) in the peraluminous plutons. Pluton nos. 1-13 keyed to table 1 (petrographic characteristics) and figure 1 (map locations). Triangle, average composition of 2,327 granites (Krauskopf, 1967); +, average composition of 962 metallogenically specialized granitoids (Tischendorf, 1977); rectangle, average composition of 226 precursor granites (Tischendorf, 1977). Polybaric minimum melting compositions (minima trend) in system $\mathrm{SiO}_{2}-\mathrm{NaAlSi}_{3} \mathrm{O}_{8}-\mathrm{KAISi}_{3} \mathrm{O}_{8}-\mathrm{H}_{2} \mathrm{O}$ indicated by open circles for $\mathrm{P}_{\mathrm{H}_{2} \mathrm{O}}$ equal to from $50 \mathrm{MPa}$ (top right circle), 100 , $200,400,500$, to $1,000 \mathrm{MPa}$ (bottom left circle) $(0.5,1,2,4$, 5 , and $10 \mathrm{kbar}$ ) (Winkler and others, 1975). 
Table 4. Average major-element, trace-element, and CIPW compositions for peraluminous plutons in eastern and southeastern

[Number in parentheses following pluton locality name corresponds to number on figure 1 and table 1 . N, number of samples on which mean anhydrous and corrected for fluorine. Major element analyses from several laboratories, using a combination of X-ray fluorescence, atomic abspectrography; $\mathrm{Rb}, \mathrm{Sr}, \mathrm{Y}, \mathrm{Zr}, \mathrm{Nb}$, and $\mathrm{Pb}$ by $\mathrm{X}$-ray fluorescence using a ${ }^{109} \mathrm{Cd}$ excitation source; $\mathrm{Sn}, \mathrm{Ba}, \mathrm{La}, \mathrm{Ce}$, and $\mathrm{Nd}$ by $\mathrm{X}$-ray fluorescence

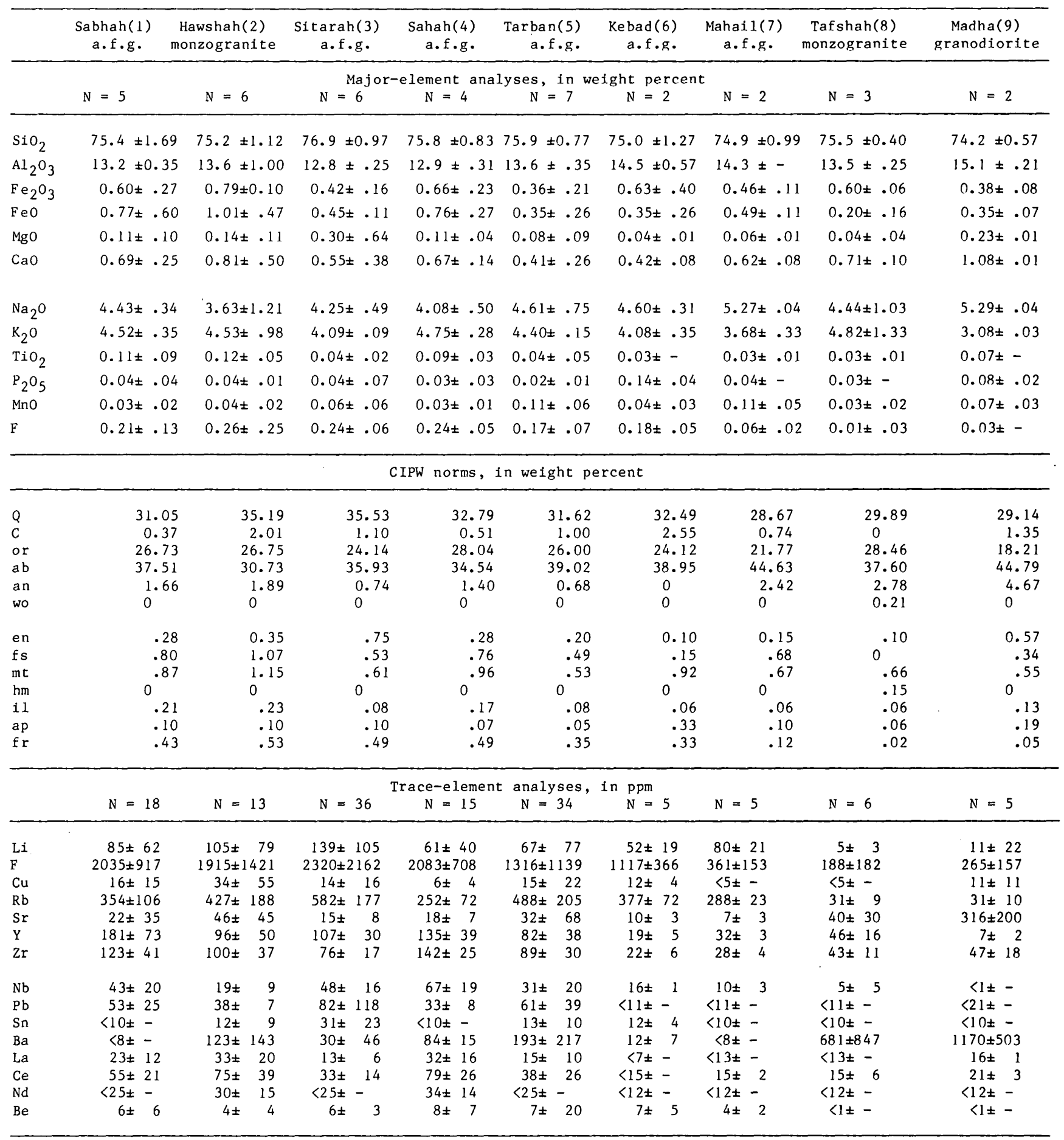

${ }^{1}$ Average of 54 analyses for 13 peraluminous plutons in the eastern and southeastern Arabian Shield.

2 Average of 692 samples of granitoid rocks, eastern and southeastern Arabian Shield (du Bray and others, 1982). 
Arabian Shield

and standard deviation $( \pm)$ are based; leader in standard deviation entry (-), zero variance. Pluton element averages normalized to 100 percent, sorption and wet chemistry methods. Trace element analyses: Li by atomic absorption; $\mathrm{F}$ by selected-ion electrode; $\mathrm{Cu}$ and $\mathrm{Be}$ by semiquantitative using a ${ }^{241} \mathrm{Am}$ excitation source. ND, no data available; a.f.g., alkali-feldspar granite]

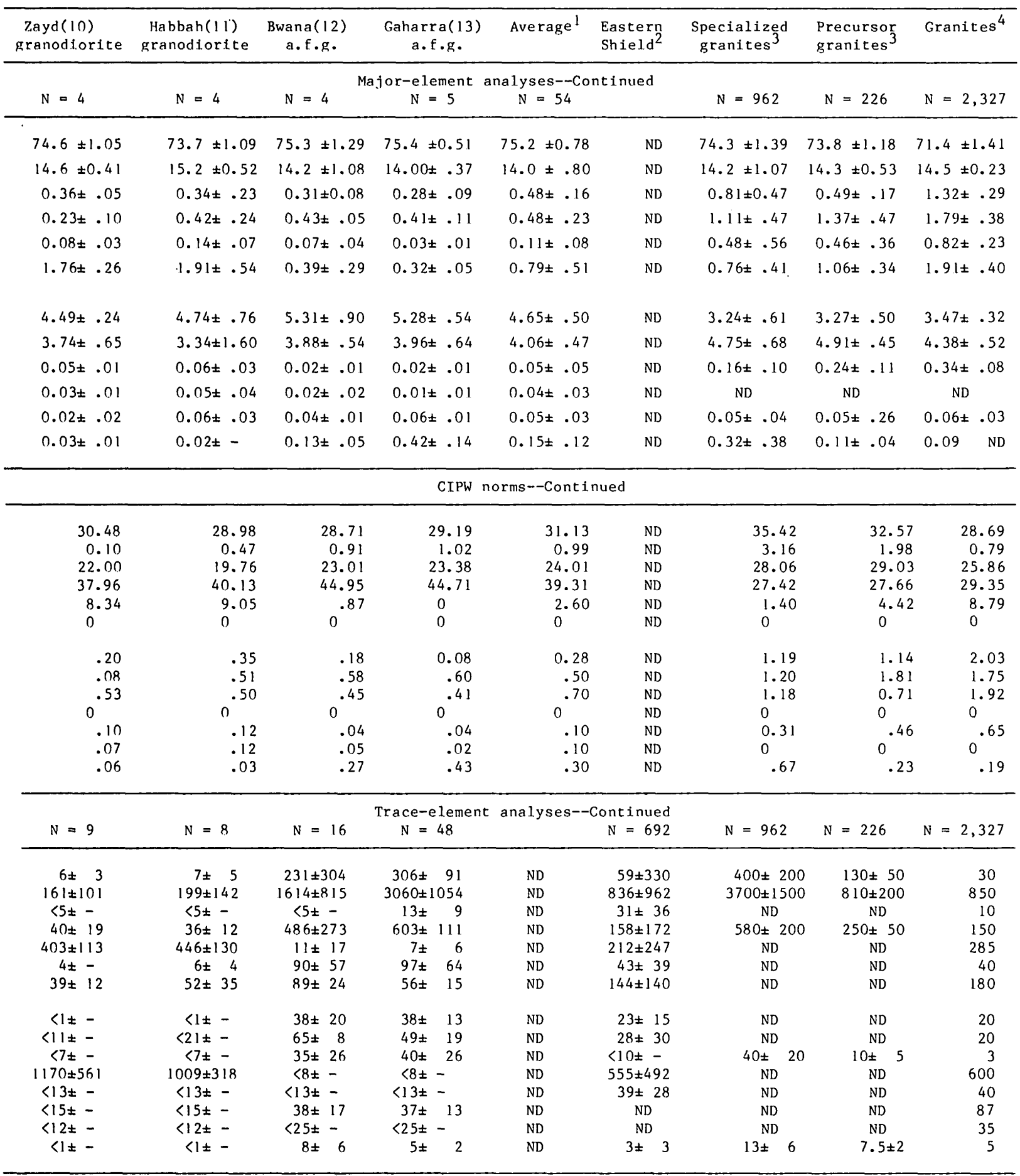

3 Tischendorf (1977).

${ }^{4}$ Krauskopf (1967, p. 639-640). 
of the Madha assemblage plutons, in particular the compositions of plutons $9-11$, are distinctly different from those of other peraluminous plutons (fig. 7). These plutons are depleted in all the lithophile elements except barium and strontium. Strontium concentrations are slightly higher than those cited for average granites, whereas barium is enriched almost twofold relative to world averages for granite (Krauskopf, 1967, p. 639-640). The other nine plutons are depleted in $\mathrm{Ba}, \mathrm{Cu}, \mathrm{La}, \mathrm{Sr}$, and $\mathrm{Zr}$ relative to average granites, but they are enriched in combinations of $\mathrm{Be}, \mathrm{Pb}, \mathrm{Sn}, \mathrm{Li}, \mathrm{F}, \mathrm{Rb}, \mathrm{Y}$, and $\mathrm{Nb}$ and have $\mathrm{Rb} / \mathrm{Sr}$ ratios that range from 9 to about 85 . In addition, some samples contain unusually high concentrations of $\mathrm{Bi}, \mathrm{W}, \mathrm{Ag}, \mathrm{Mo}$, or $\mathrm{Zn}$. The trace-element composition of the Tafshah monzogranite is transitional between the composition of the two groups of plutons. It is important to note that the various plutons are enriched in incompatible elements to substantially different degrees.

Distinctive trace-element covariation exists among the plutons studied (fig. 7). In particular, zirconium and yttrium concentrations increase in a nearly $1: 1$ ratio (fig. $7 A$ ). Yttrium and niobium concentrations display similar covariation (fig. $7 C$ ), except that the yttrium concentration increases at more than twice the rate of the niobium concentration. The plot of the agpaitic index versus zirconium content (fig. 7D) demonstrates that there is no relation between agpaitic ratio and zirconium content in nonperalkaline granites, which is consistent with the findings of Watson (1979) that the zirconium concentration of nonperalkaline granites is buffered at about $100 \mathrm{ppm}$. Variation of zirconium concentration among the peraluminous plutons may be related to the degree of magmatic evolution, the composition of the source terrane, or a combination of these factors.

Rare-earth element (REE) contents of non-Madha assemblage plutons distinguish them from Madha assemblage plutons and are typical of highly evolved intrusive rocks. Rare-earth element patterns for plutons $1-8,12$, and 13 are flat, have large negative europium anomalies, and are LREE (light REE) depleted; total REE content is high (J.S. Pallister and J.S. Stuckless, written commun., 1983). REE patterns for Madha assemblage plutons are positively sloping and are characterized by moderate to small Eu anomalies; total REE content is significantly less than in the other plutons.

\section{Isotopes}

Stacey and Stoeser (1983) have determined in a study of feldspar and whole-rock common lead compositions that the plutons in the northeastern and extreme eastern and southeastern parts of the Arabian Shield have elevated ${ }^{208} \mathrm{~Pb} /{ }^{204} \mathrm{~Pb}$ and ${ }^{207} \mathrm{~Pb} /{ }^{204} \mathrm{~Pb}$ ratios relative to their ${ }^{206} \mathrm{~Pb} /{ }^{204} \mathrm{~Pb}$ ratios and average radiogenic lead
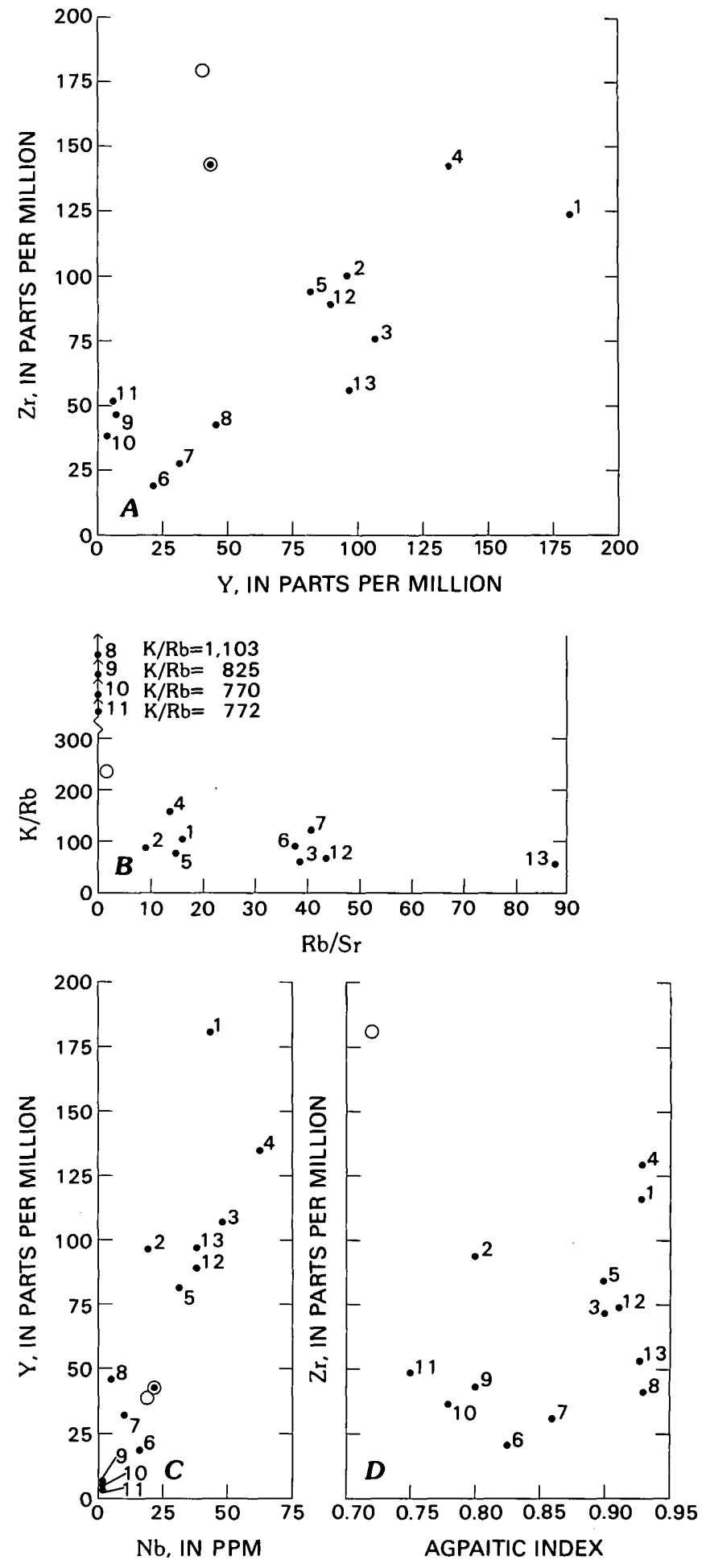

Figure 7. Trace-element variation diagrams for the peraluminous plutons. $A$, zirconium versus yttrium; $B, \mathrm{~K} / \mathrm{Rb}$ ratio versus $\mathrm{Rb} / \mathrm{Sr}$ ratio; $C$, yttrium versus niobium; $D$, zirconium versus the agpaitic index $\left(\left(\mathrm{Na}_{2} \mathrm{O}+\mathrm{K}_{2} \mathrm{O}\right) / \mathrm{Al}_{2} \mathrm{O}_{3}\right)$ on a molecular basis. Pluton numbers $1-13$ keyed to figure 1 (map locations) and table 1 (petrographic characteristics). Data are average trace-element values from table 3 . Open circle, average composition of 2,327 granites (Krauskopf, 1967); circle with dot, average composition of 692 granitoid samples from eastern and southeastern Arabian Shield (du Bray and others, 1982). 
growth curves for the mantle and oceanic crust (Doe and Zartman, 1979). These plutons are located east of the HNFZ (fig. 1). The Sabhah alkali-feldspar granite is characterized by anomalously radiogenic common lead $\left({ }^{208} \mathrm{~Pb} /{ }^{204} \mathrm{~Pb}=37.339,{ }^{207} \mathrm{~Pb} /{ }^{204} \mathrm{~Pb}=15.511,{ }^{206} \mathrm{~Pb} /{ }^{204} \mathrm{~Pb}\right.$ $=17.726$ ), whereas common lead in the Madha granodiorite $\left({ }^{208} \mathrm{~Pb} /{ }^{204} \mathrm{~Pb}=37.045,{ }^{207} \mathrm{~Pb} /{ }^{204} \mathrm{~Pb}=15.470,{ }^{206} \mathrm{~Pb} /\right.$ $\left.{ }^{204} \mathrm{~Pb}=17.697\right)$ and in the Gaharra alkali-feldspar granite $\left({ }^{208} \mathrm{~Pb} /{ }^{204} \mathrm{~Pb}=37.182,{ }^{207} \mathrm{~Pb} /{ }^{204} \mathrm{~Pb}=15.480\right.$, ${ }^{206} \mathrm{~Pb} /{ }^{204} \mathrm{~Pb}=17.891$ ) is significantly less radiogenic.

\section{MINERAL DEPOSIT POTENTIAL}

Peraluminous plutons are potential hosts to deposits of tin and tungsten. For example, the lode tin and tungsten deposits of southwest England (Jackson, 1979) and the alluvial tin deposits of Thailand and Malaysia (Ishihara and others, 1980) are characteristically associated with muscovite-bearing peraluminous granitoid rocks. A quartz-vein stockwork associated with a small, greisenized peraluminous stock and containing 0.10 percent $\mathrm{WO}_{3}$ and 0.01 percent tin was recently located near Baid al Jimalah (Cole and others, 1981; Lofts, 1982). Identification of this deposit suggests that other peraluminous plutons in the eastern and southeastern Arabian Shield might contain ore deposits.

The average compositions of the peraluminous plutons, as indicated on the ACF ternary diagram (fig. 5), suggest that only three or four of the plutons are S-type as defined by White and Chappell (1977); yet preliminary geochemical data (du Bray and others, 1982) suggest that tin deposits may exist associated with most of these plutons. Takahashi and others (1980) have also noted that some tin deposits are associated with granites whose compositions plot in the I-type field on the ACF diagram. The compositional distinction made on the ACF diagram (White and Chappell, 1977) between S- and Itype granitoid rocks-and therefore on a pluton's favorability for associated tin deposits-needs reconsideration. Perhaps, as indicated by Ishihara and others (1980), identification of ilmenite-series granitoid rocks will expedite discovery of tin deposits.

Pan concentrates of wadi sediment collected from wadis draining the peraluminous plutons in the eastern and southeastern Arabian Shield contained 1,000 ppm tin (du Bray and others, 1982), or up to 100 times the tin concentration in associated granites. Because the mica minerals are removed from the samples during panning, tin must not be concentrated in micas but in a heavy mineral such as cassiterite. Tungsten was also detected in several of these samples but did not exceed concentrations of $100 \mathrm{ppm}$. In addition, some of these samples were enriched in combinations of the elements $\mathrm{Ag}, \mathrm{Bi}, \mathrm{Zn}, \mathrm{Pb}$, and Mo relative to average values determined for felsic plutonic rocks in the eastern and southeastern Arabian Shield.

Despite the geochemical anomalies in tin and other elements, detailed ground traverses failed to identify any mineralized zones. Quartz veins and host granites were thoroughly sampled, but analyses indicate that, although concentrations of $\mathrm{Sn}, \mathrm{Mo}, \mathrm{Bi}$, and $\mathrm{Ag}$ are well above regional averages $(3,2,<1$, and $<1 \mathrm{ppm}$, respectively), surface outcrops are not strongly mineralized (du Bray, 1983b). A small wolframite-bearing quartz vein was found cutting the Tarban alkali-feldspar granite, and a single sample of a quartz vein cutting the Sitarah alkalifeldspar granite contained 1,000 ppm molybdenum, but these are exceptional occurrences. Plutons 3, 5, 12, and 13 probably warrant further study because the concentrations of tin and other trace elements in average specimens were so high (table 4).

The failure to locate either mineralized quartz-vein stockworks or greisens, despite the appropriateness of the geologic environment, should be discussed. Formation of a tin deposit requires a manyfold concentration of tin in a late-stage magmatic fluid, possibly through volatile complexing, and its subsequent precipitation in a stanniferous phase that is included either in quartz veins or in a greisen. A fluid phase must be present in order for tin to be concentrated in late-stage processes. The occurrence of primary white mica and of two independently nucleated alkali feldspars suggests that most plutons studied here were emplaced at relatively great depths. The depths may preclude early evolution of a fluid phase during crystallization, so that tin was partitioned not into a fluid phase but into the melt. To a limited extent, tin may have been incorporated in micas and oxide minerals, but the tin-saturation maximum was probably reached in melts of various high-potential plutons. Tin saturation may have resulted in nucleation of a tin-bearing phase, probably cassiterite, that was then widely disseminated throughout the plutons. When a fluid phase ultimately did exsolve, tin was no longer available for concentration, and relatively barren quartz veins were deposited in fractures.

Deposits of tin, tungsten, molybdenum, and other rare metals are generally found in the apical part of plutons emplaced at fairly shallow levels (Groves and McCarthy, 1978). Regional studies of the Arabian Shield (D.B. Stoeser, oral commun., 1982; J.W. Whitney, oral commun., 1982) suggest that erosion has extended much deeper in the southeastern Arabian Shield than in the northeastern shield and that the tops of highmineral-potential plutons have been removed by erosion. Consequently, mineral potential associated with felsic plutonic rocks is greater in plutons of the northeastern region. The discoveries in the northeastern part of the Arabian Shield of both a tungsten and tin quartz-vein stockwork associated with the peraluminous granite at Baid al Jimalah (Cole and others, 1981) and a 
tin-anomalous muscovite-topaz monzogranite with associated tin greisens in a subcaldera ring fracture (du Bray, 1982c) corroborate this finding.

\section{PETROGENESIS}

Some constraints can be placed on the genesis and crystallization of the peraluminous plutons by comparing their chemistry and petrology with experimental data. The highly differentiated major-element chemistry, incompatible trace-element-enrichment patterns, and radiogenic lead-enriched compositions of these plutons all suggest that they were generated by partial melting of preexisting continental material. The compositions of the peraluminous plutons are compared on the $\mathrm{Q}-\mathrm{Ab}$-Or ternary diagram (fig. 6), which also shows minimum melting compositions at several pressures (polybaric) in the experimental system $\mathrm{SiO}_{2}-\mathrm{NaAlSi}_{3} \mathrm{O}_{8}-\mathrm{KAlSi}_{3} \mathrm{O}_{8}-\mathrm{H}_{2} \mathrm{O}$ (Winkler and others, 1975). The average composition of the plutons is coincident with the composition of the $200 \mathrm{MPa}$ (megapascal) (or $2 \mathrm{kbar}$ (kilobar)) minimum melt for conditions of $P_{\mathrm{H}_{2} \mathrm{O}}=P_{\text {total }}$. Steiner and others (1975) indicated that determinations of intensive parameters such as temperature and pressure of crystallization based on comparisons of this sort may be tenuous and are based on certain petrogenetic assumptions. However, the convergence of chemical and petrographic data for these peraluminous plutons suggests that the full compositional range represented by averages for the peraluminous plutons of the eastern and southeastern Arabian Shield could be explained by crystallization under conditions of $P_{\mathrm{H}_{2} \mathrm{O}}$ ranging from 200 to $400 \mathrm{MPa}$ ( 2 to 4 kbar), equivalent to between 7 and $14 \mathrm{~km}$ of overburden. Figure 6 shows that the compositions of the plutons depart a little from the trend line of polybaric minimum melting compositions (minima trend) of the experimental system, but the differences are within the analytical precision of the method. In all cases, onestandard deviation bars (omitted for clarity) intersect the minima trend.

The 200- to $400-\mathrm{MPa} P_{\mathrm{H}_{2} \mathrm{O}}$ range also meets the requirements necessary for crystallization of muscovite from a granitic melt and for crystallization of two independently nucleated (nonperthitic) alkali feldspars. Muscovite crystallizes from a granite magma when $P_{\mathrm{H}_{2} \mathrm{O}}$ is greater than or equal to $300 \mathrm{MPa}(3 \mathrm{kbar})$ at about $670^{\circ}$ $C$ (Yoder and Eugster, 1954). Two discrete alkali feldspars crystallize in the experimental system $\mathrm{NaAlSi}{ }_{3} \mathrm{O}_{8}-\mathrm{KAlSi}_{3} \mathrm{O}_{8}-\mathrm{SiO}_{2}-\mathrm{H}_{2} \mathrm{O}$ in favor of a single alkali feldspar when $P_{\mathrm{H}_{2} \mathrm{O}}$ is greater than $360 \mathrm{MPa}(3.6 \mathrm{kbar})$ (Tuttle and Bowen, 1958; Morse, 1970).

The 200 - to $400-\mathrm{MPa}$ pressure range must be regarded as a maximum, however. Manning (1981) has demonstrated that the minimum melt composition in the granite system is displaced toward compositions richer in $\mathrm{Ab}$ by the presence of several percent fluorine. The high fluorine content of most plutons studied suggests that the magmas from which they crystallized may have contained up to several percent fluorine and that their eutectic compositions were affected accordingly. The pressure necessary for nucleation of two alkali feldspars may be similarly reduced by the presence of fluorine. Thermodynamic considerations regarding the pressuredependent stability of muscovite in granitic melts indicate that these micas can be stable at anomalously low pressures. Anderson and Rowley (1981) suggested that muscovite is stable at magmatic temperatures and pressures of $200 \mathrm{MPa}$ because of its non-ideal composition. No experimental data are available for the stability of zinnwaldite, but its occurrence in several of the plutons studied may not necessitate great pressure.

The presence of garnet in seven of the plutons probably reflects bulk composition variations between plutons rather than high pressure. Hsu (1968) and Green (1978) indicated that high manganese concentrations enhance garnet stability in magmas at pressures as low as $300 \mathrm{MPa}$ ( $3 \mathrm{kbar})$. This fact is in good agreement with the correlation between high manganese concentrations and garnetiferous plutons in the study area (tables 1, 4). Miller and Stoddard (1981) suggested that an elevated manganese concentration in melts may be the critical factor relative to garnet nucleation and growth. Weak zoning preserved in garnets from the Tafshah monzogranite may indicate either that manganese was concentrated during crystallization or that garnet composition in equilibrium with the melt became richer in manganese during magmatic ascent.

Preliminary common lead isotope data for the Sabhah alkali-feldspar granite indicate that its genesis involved partial melting that included a component of preexisting lower continental crust. Stacey and Stoeser (1983) suggested that the common lead composition of the Sabhah alkali-feldspar granite lies on a mixing line between the lead composition field of more radiogenic lower continental crust and the lead composition field of less radiogenic oceanic crust, as defined by Doe and Zartman (1979). Common lead data for the Gaharra alkalifeldspar granite and the Madha granodiorite are consistent with their derivation from oceanic crust, as indicated by Doe and Zartman (1979); however, the lead isotope data are at odds with other petrologic and geochemical evidence regarding the genesis of the Gaharra alkalifeldspar granite. In particular, the chemistry, modal mineralogy, and setting of this pluton are very similar to those of the other peraluminous plutons that crop out east of the HNFZ in the eastern and southeastern Arabian Shield. In addition, the Gaharra alkali-feldspar granite crops out near Najran (fig. 1), where a quartz monzonite crops out that has a lead isotopic composition consistent 
with derivation from or incorporation of older, evolved material (Stacey and Stoeser, 1983). The complexities of the common lead composition of the Gaharra alkalifeldspar granite are beyond the scope of this study, but it is important to note that most of the peraluminous plutons crop out near and east of the HNFZ in terrane in which common lead compositions indicate contribution from older continental material (Stacey and Stoeser, 1983). The isotopic composition of lead in the Madha granodiorite and probably in the other plutons of the Madha assemblage may be attributable to their position west of the HNFZ in a terrane in which common lead compositions suggest derivation from oceanic crust or depleted granulite facies material.

The peraluminous plutons, except those of the Madha assemblage, are enriched in the incompatible elements relative to global averages for granites and depleted in the compatible elements; however, the degree of enrichment and depletion varies from one pluton to the next (table 4; fig. 7). Enrichment was probably not achieved by assimilation and contamination during magma ascent because the peraluminous plutons neither contain xenoliths nor preserve assimilation textures. Only the Madha assemblage plutons (nonenriched) display evidence of wall-rock assimilation.

The Madha assemblage plutons are best considered separately because their tectonic position and chemical data indicate that, although peraluminous, they are distinctly different from the other plutons. The Tafshah monzogranite is problematic because it shares characteristics both of Madha assemblage plutons and of the other peraluminous plutons. The factors that controlled genesis of this pluton were probably transitional between the two groups, but in light of the position of the pluton west of the HNFZ-and its trace-element composition-it seems most appropriate to consider genesis of the Tafshah monzogranite with the other three Madha assemblage plutons.

The non-Madha assemblage plutons were probably derived by partial melting of old continental material, a fact that precludes derivation of the Madha plutons by advanced progressive melting of the same source terrane. The non-Madha assemblage plutons could not be derived by partial melting of noncontinental material, except for very small amounts, because the extreme incompatibleelement enrichment and the anomalously radiogenic common lead compositions characteristic of the non-Madha plutons could not be obtained. The non-Madha assemblage magmas could have been obtained by extreme fractionation of less evolved melts, which could yield incompatible-element-enriched melts, but the cumulate rocks that would also result are not in evidence. To account for the incompatible-element depletion observed for the Madha assemblage plutons, an unreasonably large extent of melting of common continental source material would be required.

The barium content of these rocks also suggests that Madha assemblage and non-Madha assemblage plutons were derived from very different sources. The principal mineralogic site of barium is potassium feldspar, whose mineral-melt distribution coefficient for barium favors concentration of barium in residual potassium feldspar (Hanson, 1978). The high barium content of the Madha assemblage rocks probably resulted from advanced partial melting of a source terrane that contained potassium feldspar, whereas the pronounced barium depletion characteristic of the other plutons probably resulted from a small amount of partial melting of material, such as graywacke, in which potassium feldspar was a minor constituent.

Trace-element plots-particularly the $\mathrm{K} / \mathrm{Rb}$ ratio versus $\mathrm{Rb} / \mathrm{Sr}$ ratio plot (fig. $7 B$ )-emphasize the dissimilarity that exists between the Madha assemblage plutons and the others. The compositions of the Madha assemblage plutons plot in fields (fig. 7) that are widely separated from fields and trends defined by the other plutons. The $\mathrm{K} / \mathrm{Rb}$ ratio versus $\mathrm{Rb} / \mathrm{Sr}$ ratio plot provides information concerning melting and crystallization events that might have produced the muscovite-bearing plutons. A trend involving an increasing $\mathrm{K} / \mathrm{Rb}$ ratio and a decreasing $\mathrm{Rb} / \mathrm{Sr}$ ratio would suggest that the plutons could have been generated by varying amounts of progressive melting of a common source. As partial melting proceeds, potassium and strontium concentrations should increase relative to rubidium concentration. Instead, the $K / R b$ ratio is nearly constant for non-Madha assemblage plutons, and the $\mathrm{Rb} / \mathrm{Sr}$ ratio is almost independent of the $\mathrm{K} / \mathrm{Rb}$ ratio. These relationships suggest that nonMadha assemblage plutons are crystallized partial melts from different source terranes.

Variation in degrees of incompatible-element enrichment between the plutons substantiates the relations indicated by the $\mathrm{K} / \mathrm{Rb}$ versus $\mathrm{Rb} / \mathrm{Sr}$ ratio plot. Concentrations of the incompatible elements $\mathrm{Zr}, \mathrm{Nb}$, and $\mathrm{Y}$ should be highest in those magmas generated by the smallest amount of partial melting (and subjected to the greatest amount of fractional crystallization), and as melting progresses the relative proportion-that is, concentration - of these elements should decrease. If the same source terrane is presumed for all plutons, then plutons $3,6,7,12$, and 13 (fig. $7 B$ ) represent the greatest degree of chemical evolution; however, plutons 1, 2, 4, and 5 (representing less evolved magma) contain greater concentrations of $\mathrm{Zr}, \mathrm{Nb}$, and $\mathrm{Y}$ (fig. $7 A, C$ ). The extent of incompatible-element enrichment is not a function of the amount of progressive melting (or subsequent fractional crystallization) of a common source. Figure $7 B$ and, less convincingly, figure $7 A, C$, and $D$ suggest that partial melting in four geochemically distinct source 
terranes could account for the observed trace-element variation. The Madha assemblage plutons (8-11) were probably generated in one source terrane, plutons 1,2 , 4 , and 5 in a second, plutons $3,6,7$, and 12 in a third, and pluton 13 in a fourth.

Crystal fractionation processes may account for within-source terrane group variation and enhancement of incompatible-element enrichment. Concentrations of yttrium and zirconium in plutons numbered 1, 2, 4, and 5 and those numbered $3,6,7$, and 12 are consistent with plagioclase fractionation (Walsh and others, 1979).

Large negative europium anomalies and flat chondrite-normalized REE patterns are characteristic of high silica intrusions (Miller and Mittlefehldt, 1982). LREE depletion in felsic magmas has been explained (Miller and Mittlefehldt, 1982) as resulting from crystallization and removal of very small grains of an LREEenriched phase such as monazite or allanite. Alternatively, these minerals may reside in the residue upon completion of partial melting. Similar processes may account for LREE depletion of some peraluminous plutons in the eastern and southeastern Arabian Shield. The large negative europium anomalies characteristic of nonMadha assemblage plutons are consistent with plagioclase fractionation. The high total REE content of the nonMadha assemblage plutons argues in favor of an evolved source for these rocks. REE data for the Madha assemblage plutons suggest an unevolved source.

\section{CONCLUSIONS}

Thirteen plutons of peraluminous monzogranite and granodiorite, similar to S-type, metallogenically specialized, ilmenite-series, and peraluminous granitoid rocks described elsewhere in the world, were identified in the eastern and southeastern Arabian Shield. These medium-grained, inequigranular rocks contain subequal amounts of quartz, microcline, and albite. Biotite or $\mathrm{Fe}$ Li mica is the principal mafic phase, muscovite occurs in six of the plutons, and trace amounts of garnet were identified in seven of the plutons. Geochemical studies indicate that at least four of the plutons could host associated tin-tungsten deposits.

Major-element and petrographic data for the peraluminous granitoids of the eastern and southeastern Arabian Shield indicate that these rocks were generated by partial melting of older continental material and subsequently crystallized under conditions of $P_{\mathrm{H}_{2} \mathrm{O}}=200-400$ $\mathrm{MPa}$ (2-4 kbar). The trace-element and common lead isotope data indicate that most of the peraluminous plutons were produced by partial melting involving a component of old continental crust. The Madha assemblage plutons, however, must have been produced as partial melts of geochemically primitive material. Magma genesis may have been initiated in response to a collisional event that mobilized the crust adjacent to the Hulayfah-Ad Dafinah and Nabitah-Hamdah fault zones, the supposed suture zone. Compositional variations in the peraluminous plutons across the fault zone indicate that the two colliding plates were compositionally distinct; the eastern plate was evolved continental crust, whereas the western plate was geochemically primitive, oceanic crust or depleted granulite facies material. The distinctive composition of the plutons suggests that significant regional or temporal differences related to magma genesis, including compositional variation and variation of physical conditions within the source crust, may have existed within the developing Arabian Shield. The peraluminous plutons of the eastern and southeastern Arabian Shield owe their gross petrologic similarities not to a common source terrane but to a set of relatively similar physical conditions that prevailed during their individual genesis.

\section{REFERENCES CITED}

Anderson, J.L., and Rowley, M.C., 1981, Synkinematic intrusion of peraluminous and associated metaluminous granitic magmas, Whipple Mountains, California: Canadian Mineralogist, v. 19, p. 83-101.

Chappell, B.W., and White, A.J.R., 1974, Two contrasting granite types: Pacific Geology, v. 8, p. 173-174.

Clifford, T.N., 1970, The structural framework of Arabia, in Clifford, T.N., and Gass, I.G., eds., African magmatism and tectonics: Darien, Conn., Hafner, p. 1-26.

Cole, J.C., Smith, C.W., and Fenton, M.D., 1981, Preliminary investigation of the Baid al Jimalah tungsten deposit, Kingdom of Saudi Arabia: U.S. Geological Survey Saudi Arabian Mission Technical Record 20 (Interagency Report 377), $26 \mathrm{p}$.

Cox, K.G., Bell, J.D., and Pankhurst, R.J., 1979, The interpretation of igneous rocks: London, Allen and Unwin, 450 p.

Deer, W.A., Howie, R.A., and Zussman, J., 1962, Rockforming minerals: London, Longmans, v. 3, 270 p.

1966, An introduction to the rock-forming minerals: London, Longmans, 528 p.

Delfour, Jacques, 1979, Geologic map of the Halaban quadrangle, sheet 23G, Kingdom of Saudi Arabia (with topographic base): Saudi Arabian Directorate General of Mineral Resources Geologic Map GM-46-A, 32 p., scale $1: 250,000$.

1980, Geologic map of the Wadi ar Rika quadrangle, sheet 22G, Kingdom of Saudi Arabia: Saudi Arabian Directorate General of Mineral Resources Geologic Map GM-51-A, 34 p., scale 1:250,000.

Doe, B.R., and Zartman, R.E., 1979, Plumbotectonics I, the Phanerozoic, in Barnes, H.L., ed., Geochemistry of hydrothermal ore deposits: New York, John Wiley, p. 22-70.

du Bray, E.A., 1983a, Petrology of muscovite-bearing granitoid plutons in the eastern and southeastern Arabian Shield, Kingdom of Saudi Arabia: Saudi Arabian Deputy Ministry for Mineral Resources Open-File Report USGS-OF-03-10, $36 \mathrm{p}$. 
1983b, Mineral potential of selected felsic plutons in the eastern and southeastern Arabian Shield, Kingdom of Saudi Arabia: Saudi Arabian Deputy Ministry for Mineral Resources Open-File Report USGS-OF-03-39, 58 p.

1983c, Reconnaissance geology of the Jabal as Silsilah quadrangle, sheet 26/42 D, Kingdom of Saudi Arabia: Saudi Arabian Deputy Ministry for Mineral Resources Technical Record USGS-TR-03-4, 52 p., scale 1:100,000.

du Bray, E.A., Elliott, J.E., and Stoeser, D.B., 1982, Geochemical evaluation of felsic plutonic rocks in the eastern and southeastern Arabian Shield, Kingdom of Saudi Arabia: Saudi Arabian Deputy Ministry for Mineral Resources Technical Record USGS-TR-02-2, $53 \mathrm{p}$.

Drysdall, A.R., 1979, Petrogenesis of two peralkaline microgranites from N.W. Hijaz; some considerations relevant to further prospecting: Saudi Arabian Directorate General of Mineral Resources Open-File Report DGMR-705, $51 \mathrm{p}$.

Elliott, J.E., 1980, Tin-bearing granite of Jabal al Gaharra in the southern Arabian Shield, Kingdom of Saudi Arabia: U.S. Geological Survey Saudi Arabian Mission Technical Record 4 (Interagency Report 299), 28 p.

1983, Peralkaline and peraluminous granites and related mineral deposits of the Arabian Shield, Kingdom of Saudi Arabia: Saudi Arabian Deputy Ministry for Mineral Resources Open-File Report USGS-OF-03-56, 37 p.

Green, T.H., 1978, Garnet in silicic liquids and its possible use as a P-T indicator: Contributions to Mineralogy and Petrology, v. 65, p. 59-67.

Greenwood, W.R., Anderson, R.E., Fleck, R.J., and Roberts, R.J., 1980, Precambrian geologic history and plate tectonic evolution of the Arabian Shield: Saudi Arabian Directorate General of Mineral Resources Bulletin 24, 35 p.; also 1977, U.S. Geological Survey Saudi Arabian Project Report 222, 97 p.; both include colored geologic map, scale $1: 4,000,000$.

Greenwood, W.R., Stoeser, D.B., Fleck, R.J., and Stacey, J.S., 1982, Late Proterozoic Island-arc complexes and tectonic belts in the southern part of the Arabian Shield, Kingdom of Saudi Arabia: Saudi Arabian Deputy Ministry for Mineral Resources Open-File Report USGS-OF-02-8, 46 p.; also 1983, U.S. Geological Survey Open-File Report 83-296, 49 p.

Groves, D.I., and McCarthy, T.S., 1978, Fractional crystallization and the origin of tin deposits in granitoids: Mineralium Deposita, v. 13, p. 11-26.

Hanson, G.N., 1978, The application of trace elements to the petrogenesis of igneous rocks of granitic composition: Earth and Planetary Science Letters, v. 38, p. 26-43.

Hsu, L.C., 1968, Selected phase relationships in the system Al$\mathrm{Mn}-\mathrm{Fe}-\mathrm{Si}-\mathrm{O}-\mathrm{H}$, a model for garnet equilibria: Journal of Petrology, v. 9, p. 40-83.

Ishihara, Shunso, 1977, The magnetite-series and ilmenite-series granitic rocks: Mining Geology, v. 27, p. 293-305.

Ishihara, Shunso, Sawata, Hideho, Shibata, Ken, Terashima, Shigera, Arrykul, Surapon, and Kohei, Sato, 1980, Granites and Sn-W deposits of peninsular Thailand: Mining Geology Special Issue 8, p. 223-241.

Jackson, N.J., 1979, Geology of the Cornubian tin field: A review: Geological Society of Malaysia Bulletin 11, p. 209-237.
Kanaan, F.M., 1979, The geology, petrology, and geochemistry of the granitic rocks of Jabal al Hawshah and vicinity, Jabal al Hawshah quadrangle, Kingdom of Saudi Arabia: Saudi Arabian Directorate General of Mineral Resources Bulletin 23, $114 \mathrm{p}$.

Krauskopf, K.B., 1967, Introduction to geochemistry: New York, McGraw-Hill, 721 p.

Lofts, P.G., 1982, A preliminary evaluation of the Baid al Jimalah tungsten prospect: Saudi Arabian Deputy Ministry for Mineral Resources Open-File Report RF-OF-02-21, 223 p.

Manning, D.A.C., 1981, The effect of fluorine on liquidus phase relationships in the system $\mathrm{Qz}-\mathrm{Ab}$-Or with excess water at $1 \mathrm{~kb}$ : Contributions to Mineralogy and Petrology, v. 76, p. 206-215.

Miller, C.F., and Bradfish, L.J., 1980, An inner Cordilleran belt of muscovite-bearing plutons: Geology, v. 8, p. 412-416.

Miller, C.F., and Mittlefehldt, D.W., 1982, Depletion of light rareearth elements in felsic magmas: Geology, v. 10, p. 129-133.

Miller, C.F., and Stoddard, E.F., 1981, The role of manganese in the paragenesis of magmatic garnet-An example from the Old Woman-Piute Range, California: Journal of Geology, v. 89, p. 233-246.

Miller, C.F., Stoddard, E.F., Bradfish, L.J., and Dollase, W.A., 1981, Composition of plutonic muscovite-genetic implications: Canadian Mineralogist, v. 19, p. 25-34.

Morse, S.A., 1970, Alkali feldspars with water at $5 \mathrm{~kb}$ pressure: Journal of Petrology, v. 11, p. 221-251.

Sable, E.G., 1982, Reconnaissance geology of part of the Najran quadrangle, sheet 17/44 C, Kingdom of Saudi Arabia: Saudi Arabian Deputy Ministry for Mineral Resources Open-File Report USGS-OF-03-7, 25 p., scale 1:100,000.

Schmidt, D.L., and Brown, G.F., 1982, Major-element chemical evolution of the late Proterozoic shield of Saudi Arabia: Saudi Arabian Deputy Ministry for Mineral Resources Open-File Report USGS-OF-02-88, 34 p.; also in press, Jiddah, King Abdulaziz University, Faculty of Earth Sciences, First Symposium of Pan-African Project 164, Proceedings.

Schmidt, D.L., Hadley, D.G., and Stoeser, D.B., 1979, Late Proterozoic crustal history of the Arabian Shield, southern Najd province, Kingdom of Saudi Arabia: U.S. Geological Survey Saudi Arabian Project Report 251, 44 p.; also 1979, in Tahoun, S.A., ed., Evolution and mineralization of the Arabian-Nubian Shield: Oxford-New York, Pergamon Press, Jiddah, King Abdulaziz University, Institute of Applied Geology Bulletin 3, v. 2, p. 41-58.

Shand, S.J., 1949, Eruptive rocks, their genesis, composition, classification, and their relation to ore deposits, with a chapter on Meteorites, 3rd edition: London, Thomas Murby, $488 \mathrm{p}$.

Stacey, J.S., and Stoeser, D.B., 1983, Distribution of oceanic and continental leads in the Arabian-Nubian Shield: Saudi Arabian Deputy Ministry for Mineral Resources Open-File Report USGS-OF-03-55, 36 p.

Stacey, J.S., Stoeser, D.B., and Greenwood, W.R., 1983, U/Pb zircon geochronology and geologic evolution of the Halaban-Al Amar region of the eastern Arabian Shield, Kingdom of Saudi Arabia: Unpublished report available from the U.S. Geological Survey, Jiddah, Saudi Arabia.

Steiner, J.C., Jahns, R.H., and Luth, W.C., 1975, Crystallization of alkali feldspar and quartz in the haplogranite system $\mathrm{NaAlSi}{ }_{3} \mathrm{O}_{8}-\mathrm{KAlSi}_{3} \mathrm{O}_{8}-\mathrm{SiO}_{2}-\mathrm{H}_{2} \mathrm{O}$ at $4 \mathrm{~kb}$ : Geological Society of America Bulletin, v. 86, p. 83-98. 
Stoeser, D.B., 1983, Reconnaissance geology of the Wadi Tarib quadrangle, sheet 18/43 C, Kingdom of Saudi Arabia: Unpublished report available from the U.S. Geological Survey, Jiddah, Saudi Arabia.

Stoeser, D.B., and Elliott, J.E., 1980, Post-orogenic peralkaline and calc-alkaline granites and associated mineralization of the Arabian Shield, Kingdom of Saudi Arabia, in Cooray, P.G., and Tahoun, S.A., eds., Evolution and mineralization of the Arabian Nubian Shield, volume 4: Oxford and New York, Pergamon Press; Jiddah, King Abdulaziz University, Institute of Applied Geology Bulletin 3, p. 1-23.

Stoeser, D.B., Fleck, R.J., and Stacey, J.S., 1982, Geochronology and origin of an early tonalite gneiss of the Wadi Tarib batholith and the formation of syntectonic gneiss complexes in the southeastern Arabian Shield, Kingdom of Saudi Arabia: Saudi Arabian Deputy Ministry for Mineral Resources Open-File Report USGS-OF-02-62, 27 p.; also in press Jiddah, King Abdulaziz University, Faculty of Earth Sciences, First Symposium on Pan-African crustal evolution in the Arabian-Nubian Shield, IGCP Project 164, Proceedings.

Stoeser, D.B., and Stacey, J.S., 1983, Pan-African age continental collision in and plutonic rock U-Pb zircon geochronology of the southeastern Arabian Shield, Kingdom of Saudi Arabia: Unpublished data available from the U.S. Geological Survey, Jiddah, Saudi Arabia.

Streckeisen, A.L., 1976, To each plutonic rock its proper name: Earth-Science Reviews, v. 12, p. 1-33.
Takahashi, Masaki, Aramaki, Shigeo, and Ishihara, Shunso, 1980, Magnetite-series-ilmenite-series versus I-type-S-type granitoids: Mining Geology Special Issue 8, p. 13-28.

Tischendorf, G., 1977, Geochemical and petrographic characteristics of silicic magmatic rocks associated with rareelement mineralization, in Stemprok, M., and others, eds., Metallization associated with acid magmatism: Prague, Czechoslovakia Geological Survey, v. 2, p. 41-96.

Tuttle, O.F., and Bowen, N.L., 1958, Origin of granite in the light of experimental studies in the system $\mathrm{NaAlSi}_{3} \mathrm{O}_{8}$ $\mathrm{KAlSi}_{3} \mathrm{O}_{8}-\mathrm{SiO}_{2}-\mathrm{H}_{2} \mathrm{O}$ : Geological Society of America Memoir 74, $152 \mathrm{p}$.

Walsh, J.N., Beckinsdale, R.D., Skelhorn, R.R., and Thorpe, R.S., 1979, Geochemistry and petrogenesis of Tertiary granitic rocks from the island of Mull, northwest Scotland: Contributions to Mineralogy and Petrology, v. 71, p. 99-166.

Watson, E.B., 1979, Zircon saturation in felsic liquidsExperimental results and applications to trace element geochemistry: Contributions to Mineralogy and Petrology, v. 70 , p. $407-419$.

White, A.J.R., and Chappell, B.W., 1977, Ultrametamorphism and granitoid genesis: Tectonophysics, v. 43, p. 7-22.

Winkler, H.G.F., Boese, M., and Marcopoulos, T., 1975, Low temperature granitic melts: Neues Jahrbuch fur Mineralogie Monatshefte, v. 6, p. 245-268.

Yoder, H.S., Jr., and Eugster, H.P., 1954, Phlogopite synthesis and stability range: Geochimica et Cosmochimica Acta, v. 6 , p. $157-185$. 
Chapter C

\title{
Muscovites from Selected Aplites and Quartz Veins of White Pine County, Nevada
}

\author{
By D.E. LEE, E.L.M. BRANDT, and R.E. VAN LOENEN
}

Selected muscovite data indicate both Jurassic and

Cretaceous hydrothermal activity associated with quartz veins

U.S. GEOLOGICAL SURVEY BULLETIN 1694

CONTRIBUTIONS TO MINERAL RESOURCES RESEARCH， 1984 


\title{
CONTENTS
}

\author{
Abstract 35 \\ Introduction 35 \\ Muscovite analyses 36 \\ Muscovites from aplites $\mathbf{3 9}$ \\ Muscovites from quartz veins $\mathbf{3 9}$ \\ References cited 39
}

FIGURE

1. Map showing localities of analyzed muscovites 35

TABLES

1. Analytical data for muscovites from White Pine County, Nevada 36

2. Additional data for analyzed muscovites $\mathbf{3 8}$ 


\title{
Muscovites from Selected Aplites and Quartz Veins of White Pine County, Nevada
}

\author{
By D.E. Lee, E.L.M. Brandt, and R.E. Van Loenen
}

\begin{abstract}
Chemical analyses, physical properties, stable-isotope data, K-Ar ages, and coexisting minerals are listed for muscovites from selected aplites and quartz veins of White Pine County, Nevada.

Two muscovites were recovered from a set of quartz veins in an area of wolframite mineralization in the southern Snake Range. Data obtained for these muscovites indicate that there may have been both Jurassic and Cretaceous hydrothermal activity associated with the quartz veins, corresponding to known episodes of magmatic activity in the area.

One of the quartz-vein muscovites, present with minor amounts of wolframite, contains 1.90 weight percent fluorine. This may be the most fluorine-rich naturally occurring muscovite reported to 1985 .
\end{abstract}

\section{INTRODUCTION}

This is one of a series of reports resulting from work on the granitoid rocks of eastern Nevada during the past 20 years. In our efforts to understand these rocks we have selected particular samples for intensive study. For example, where possible we have tried to obtain (1) data on coexisting minerals and (2) different kinds of analytical data for splits from a given mineral fraction. Here we bring together chemical, radiometric-age, and stableisotope data for muscovites from selected quartz veins and aplites of eastern Nevada (fig. 1). We also summarize previously reported field data and information on minerals coexisting with these muscovites. A given sample number refers to the whole rock and to each of the minerals recovered from that rock. We emphasize that the different types of data reported for each of these muscovites were obtained on splits taken from the same mineral fraction.

The muscovites analyzed were recovered from the respective samples after grinding each rock to -150 mesh and washing the powder in tap water to remove material smaller than about $40 \mu \mathrm{m}$ (micrometers). The final purification of each of the muscovites was by repeated centrifuging in density-adjusted mixtures of methylene iodide and bromoform and by repeated passes through

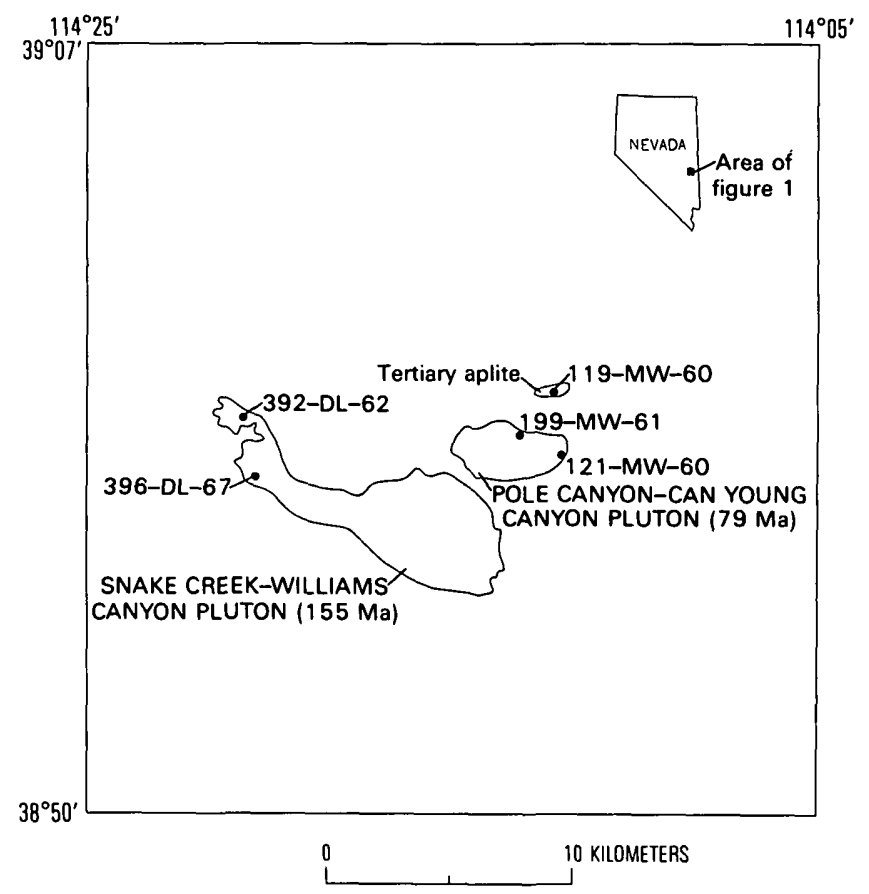

Figure 1. Localities of analyzed muscovites. Outlines of intrusions modified from map of Hose and Blake (1976). Several other intrusions within map area are not shown for the sake of simplicity. Sample $245-\mathrm{MW}-60$ is from about $83 \mathrm{~km}$ north of locality of samples $119-\mathrm{MW}-60$ and $119-\mathrm{MW}-61$. Exact coordinates of all samples are listed in table 1.

the Frantz isodynamic separator.' Densities of the analyzed muscovites were determined by the suspension method during centrifuging. Each of these muscovites fractionated over a very narrow density range, indicating a similarly small range of composition.

Major elements were determined by the chemical methods described by Peck (1964) and calculated on the basis of $24(\mathrm{O}, \mathrm{OH}, \mathrm{F}, \mathrm{Cl})$ to the general mica formula $\mathrm{X}_{2} \mathrm{Y}_{4-6} \mathrm{Z}_{8} \mathrm{O}_{20}(\mathrm{OH}, \mathrm{F}, \mathrm{Cl})_{4}$, using the computer program described by Jackson and others (1967). Calculated values for density and cell volume were determined by the same program. The observed cell parameters were obtained by

\footnotetext{
'Any use of trade names in this report is for descriptive purposes only and does not imply endorsement by the U.S. Geological Survey.
} 
least squares refinement of powder diffractometer data, with an internal standard of $\mathrm{CaF}_{2}$ and a self-indexing computer program developed by Evans and others (1963). Quantitative barium, rubidium, and strontium values were determined by X-ray fluorescence (Lee and Doering, 1974, barium; and 1980, rubidium and strontium). Results of semiquantitative spectrographic analyses are based on their identity with geometric brackets whose boundaries are 1.2, 0.83, 0.56, $0.38,0.26,0.18,0.12$, and so forth, and are reported arbitrarily as midpoints of these brackets: $1,0.7,0.5,0.3,0.2,0.15$, and 0.1 , respectively. The precision of a reported value is approximately plus or minus one bracket at 68 percent confidence or two brackets at 95 percent confidence.

Stable-isotope data are based on the SMOW (standard mean ocean water) standard (Friedman and O'Neil, 1977).

\section{MUSCOVITE ANALYSES}

All of the analyzed muscovites (table 1; fig. 1) are $2 \mathrm{M}_{1}$ micas, as determined from $\mathrm{X}$-ray diffraction patterns. Ionic ratios are close to the ideals for dioctahedral mica, and rather good agreement exists between the observed and calculated values for density and cell volume (table 2). Coexisting minerals present in "sparse" or "trace" amounts were detected only during mineral separation work. Those listed as sparse make up an estimated 0.02-0.05 weight percent of the whole rock. Each trace mineral makes up less than about 0.005 weight percent of the rock. We emphasize that such minerals as gahnite and columbite-tantalite are not recognizable in the field.

Table 1. Analytical data for muscovites from White Pine County, Nev.

[Chemical analyses by E.L. Munson Brandt. Quantitative Ba, Rb, and $\mathrm{Sr}$ analyses by W.P. Doering. Semiquantitative spectrographic analyses by L.A. Bradley. Leaders (---), not determined]

\begin{tabular}{|c|c|c|c|c|c|c|}
\hline \multirow[b]{2}{*}{$\begin{array}{l}\text { Sample No.-- } \\
\text { Sample locali }\end{array}$} & \multicolumn{4}{|c|}{ Muscovites from aplites } & \multicolumn{2}{|c|}{ Muscovites from quartz veins } \\
\hline & $\begin{array}{l}\text { 119-MW-60 } \\
\text { ty: }\end{array}$ & $1_{199-M W-61}$ & $121-\mathrm{MW}-60$ & $245-M W-60$ & $392-D L-67$ & $396-D L-67$ \\
\hline Lat N.----- & $38^{\circ} 59^{\prime} 30^{\prime \prime}$ & $38^{\circ} 58^{\prime} 11^{\prime \prime}$ & $38^{\circ} 58^{\prime} 31^{\prime \prime}$ & $39^{\circ} 35^{\prime} 55^{\prime \prime}$ & $38^{\circ} 58^{\prime} 36^{\prime \prime}$ & $38^{\circ} 57^{\prime} 04^{\prime \prime}$ \\
\hline Long w.----- & $114^{\circ} 12^{\prime} 32^{\prime \prime}$ & $114^{\circ} 13^{\prime} 12^{\prime \prime}$ & $114^{\circ} 11^{\prime} 57^{\prime \prime}$ & $114^{\circ} 07^{\prime} 55^{\prime \prime}$ & $114^{\circ} 211^{\prime} 17^{\prime \prime}$ & $114^{\circ} 20^{\prime} 36^{\prime \prime}$ \\
\hline \multicolumn{7}{|c|}{ Chemical analyses (weight percent) } \\
\hline $\mathrm{SiO}_{2}$ & 46.08 & 45.96 & 49.95 & 46.27 & 46.36 & 47.54 \\
\hline $\mathrm{Al}_{2} \mathrm{O}_{3}$ & 30.10 & 32.52 & 30.30 & 33.57 & 32.71 & 32.40 \\
\hline $\mathrm{Fe}_{2} \mathrm{O}_{3}$ & 3.29 & 3.15 & 2.84 & 1.81 & 1.54 & .59 \\
\hline $\mathrm{FeO}$ & 2.47 & 1.89 & 1.11 & 1.61 & 1.51 & 1.77 \\
\hline MgO & 1.38 & .28 & .53 & .54 & 1.45 & .94 \\
\hline $\mathrm{CaO}$ & .00 & .00 & .08 & .00 & .00 & .00 \\
\hline $\mathrm{Na}_{2} \mathrm{O}$ & 1.02 & .54 & 1.29 & .54 & .49 & .23 \\
\hline $\mathrm{K}_{2} \mathrm{O}$ & 10.45 & 10.86 & 9.53 & 10.79 & 10.82 & 11.18 \\
\hline $\mathrm{H}_{2} \mathrm{O}^{(+)}$ & 3.84 & 4.09 & -- & 4.15 & 4.20 & 3.65 \\
\hline $\mathrm{H}_{2}^{2} \mathrm{O}^{(-)}$ & .06 & .03 & .05 & .05 & .02 & .01 \\
\hline $\mathrm{TiO}_{2}$ & .60 & .11 & .20 & .15 & .39 & .20 \\
\hline $\mathrm{P}_{2} \mathrm{O}_{5}^{2}$ & .01 & .01 & -- & .01 & .04 & .01 \\
\hline $\mathrm{MnO}$ & .26 & .13 & -- & .06 & .06 & .29 \\
\hline $\mathrm{Cl}$ & .00 & .00 & .01 & .01 & .00 & .00 \\
\hline F & .71 & .42 & .45 & .58 & .24 & 1.90 \\
\hline Subtotal. & 100.27 & 99.99 & -- & 100.14 & 99.83 & 100.71 \\
\hline Less 0 & .30 & .18 & -- & .24 & .10 & $\begin{array}{r}.80 \\
\end{array}$ \\
\hline Total & 99.97 & 99.81 & -- & 99.90 & 99.73 & 99.91 \\
\hline \multicolumn{7}{|c|}{ Quantitative $\mathrm{Ba}, \mathrm{Rb}, \mathrm{Sr}$ (weight percent) } \\
\hline $\mathrm{Ba}$ & 0.0071 & 0.0011 & -- & -- & 0.2717 & 0.0720 \\
\hline $\mathrm{Rb}$ & .1844 & .3110 & -- & -- & .0666 & .0957 \\
\hline $\mathrm{Sr}$ & .00003 & .00002 & -- & -- & .0044 & .00117 \\
\hline
\end{tabular}


Table 1. Analytical data for muscovites from White Pine County, Nev.-Continued

\begin{tabular}{|c|c|c|c|c|c|c|}
\hline \multirow[b]{2}{*}{$\begin{array}{l}\text { Sample No.-- } \\
\text { Sample locali } \\
\text { Lat N.-- } \\
\text { Long W.---- }\end{array}$} & \multicolumn{4}{|c|}{ Muscovites from aplites } & \multicolumn{2}{|c|}{ Muscovites from quartz veins } \\
\hline & $\begin{array}{l}119-M W-60 \\
\text { ty: } \\
38^{\circ} 59 \cdot 30^{\prime \prime} \\
114^{\circ} 12^{\prime} 32^{\prime \prime}\end{array}$ & $\begin{array}{l}1_{199-M W-61} \\
38^{\circ} 58^{\prime} 11^{\prime \prime} \\
114^{\circ} 13^{\prime} 12^{\prime \prime}\end{array}$ & $\begin{array}{l}121-\mathrm{MW}-60 \\
38^{\circ} 58^{\prime} 31^{\prime \prime} \\
11^{\circ} 11^{\prime} 57^{\prime \prime}\end{array}$ & $\begin{array}{l}245-M W-60 \\
39^{\circ} 35^{\prime} 55^{\prime \prime} \\
11^{\circ} 07^{\prime} 55^{\prime \prime}\end{array}$ & $\begin{array}{l}392-D L-67 \\
38^{\circ} 58^{\prime} 36^{\prime \prime} \\
11^{\circ} 21^{\prime} 17^{\prime \prime}\end{array}$ & $\begin{array}{l}396-D L-67 \\
38^{\circ} 57^{\prime} 04^{\prime \prime} \\
11^{\circ} 20^{\prime} 36^{\prime \prime}\end{array}$ \\
\hline \multicolumn{7}{|c|}{ Number of ions on basis of $24(0, O H, F, C 1)$} \\
\hline $\begin{array}{c}\underline{Z}\left\{\begin{array}{l}\mathrm{P}^{5+} \\
\mathrm{Si} \\
\mathrm{Al} I V\end{array}\right. \\
\underline{Y}\left\{\begin{array}{l}\mathrm{Al}^{\mathrm{VI}} \\
\mathrm{Fe}^{3+} \\
\mathrm{T} i \\
\mathrm{Mg} \\
\mathrm{Fe} \mathrm{e}^{2+} \\
\mathrm{Mn}\end{array}\right. \\
\underline{X} \begin{array}{l}\mathrm{Ca} \\
\mathrm{Na} \\
\mathrm{K} \\
\mathrm{Ba} \\
\mathrm{Rb}\end{array} \\
\mathrm{OH} \\
\mathrm{F} \\
\mathrm{Cl}\end{array}$ & $\begin{array}{l}\left.-\begin{array}{l}- \\
6.28 \\
1.72\end{array}\right\} 8.00 \\
\left.\begin{array}{r}3.12 \\
.34 \\
.06 \\
.28 \\
.28 \\
.03\end{array}\right\} 4.11 \\
.00 \\
.27 \\
\left.\begin{array}{l}1.82 \\
.00 \\
.02\end{array}\right\} 2.11 \\
\left.\begin{array}{l}3.49 \\
.31 \\
.00\end{array}\right\} 3.80\end{array}$ & $\left.\begin{array}{l}\left.\begin{array}{l}-- \\
6.23 \\
1.77\end{array}\right\} 8.00 \\
3.42 \\
.32 \\
.01 \\
.06 \\
.21 \\
.02\end{array}\right\} 4.04$ & $\left.\begin{array}{l}\left.\begin{array}{l}-- \\
6.62 \\
1.38\end{array}\right\} 8.00 \\
3.35 \\
.28 \\
.02 \\
.10 \\
.12 \\
-- \\
.02 \\
.33 \\
1.61 \\
-- \\
--\end{array}\right\} 1.96$ & $\left.\begin{array}{l}\left.\begin{array}{l}-- \\
6.22 \\
1.78\end{array}\right\} 8.00 \\
3.54 \\
.18 \\
.02 \\
.11 \\
.18 \\
.01\end{array}\right\} 4.04$ & $\left.\begin{array}{l}\left.\begin{array}{r}0.01 \\
6.24 \\
1.75\end{array}\right\} 8.00 \\
3.44 \\
.16 \\
.04 \\
.29 \\
.17 \\
.01\end{array}\right\} 4.11$ & $\left.\begin{array}{l}\left.\begin{array}{l}-- \\
6.37 \\
1.63\end{array}\right\} 8.00 \\
3.49 \\
.06 \\
.02 \\
.19 \\
.20 \\
.03\end{array}\right\} 3.99$ \\
\hline \multicolumn{7}{|c|}{ Semiquantitative spectrographic analyses (weight percent) } \\
\hline $\begin{array}{l}\mathrm{B} \\
\mathrm{Ba} \\
\mathrm{Be} \\
\mathrm{Cr}\end{array}$ & $\begin{array}{l}\left.2^{0}\right)^{2} \\
.0015 \\
.0003\end{array}$ & $\begin{array}{l}\left(\begin{array}{l}0.005 \\
0^{.003}\end{array}\right. \\
.003\end{array}$ & $\begin{array}{l}0.003 \\
.003 \\
.002 \\
0\end{array}$ & $\begin{array}{l}0 \\
.015 \\
.0005 \\
.0001\end{array}$ & $\begin{array}{l}0.005 \\
\left(\begin{array}{l}2 \\
.001 \\
.001 \\
.001\end{array}\right.\end{array}$ & 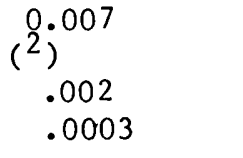 \\
\hline $\begin{array}{l}\mathrm{Cu} \\
\mathrm{Ga} \\
\mathrm{Li} \\
\mathrm{Nb}\end{array}$ & $\begin{array}{l}.0007 \\
.015 \\
.15 \\
.02\end{array}$ & $\begin{array}{l}.0002 \\
.03 \\
.03 \\
.02\end{array}$ & $\begin{array}{l}.0005 \\
.02 \\
.07 \\
.015\end{array}$ & $\begin{array}{l}.0005 \\
.015 \\
.02 \\
.005\end{array}$ & $\begin{array}{l}.0002 \\
.01 \\
.02 \\
.002\end{array}$ & $\begin{array}{l}.0003 \\
.005 \\
.05 \\
.001\end{array}$ \\
\hline $\begin{array}{l}\mathrm{N} 1 \\
\mathrm{~Pb} \\
\mathrm{Sc} \\
\mathrm{Sn}\end{array}$ & $\begin{array}{l}.0005 \\
.015 \\
.015\end{array}$ & $\begin{array}{l}0 \\
.0015 \\
.0005 \\
.05\end{array}$ & $\begin{array}{l}0 \\
0 \\
0 \\
0\end{array}$ & $\begin{array}{l}0 \\
0 \\
.001 \\
.003\end{array}$ & $\begin{array}{l}0 \\
.002 \\
.0015 \\
.01\end{array}$ & $\begin{array}{l}0 \\
0 \\
.0007 \\
.003\end{array}$ \\
\hline $\begin{array}{l}\mathrm{Sr} \\
\mathrm{V} \\
\mathrm{Zn} \\
\mathrm{Zr}\end{array}$ & $\begin{array}{l}\left({ }^{2}\right) \\
0 \\
0\end{array}$ & $\begin{array}{l}(2) \\
\quad .0007 \\
.07 \\
.0015\end{array}$ & $\begin{array}{l}0 \\
.002 \\
.07 \\
.005\end{array}$ & $\begin{array}{l}.002 \\
.001 \\
.003\end{array}$ & $\begin{array}{l}\left({ }^{2}\right) \\
.015 \\
0.07\end{array}$ & $\begin{array}{l}(2) \\
0 \\
0\end{array}$ \\
\hline
\end{tabular}

\footnotetext{
${ }^{1}$ St ructural formula for $121-\mathrm{MW}-60$ calculated on anhydrous basis of $22(0)$. See Ernst, 1963, p. 1359).

${ }^{2}$ See quantitative $\mathrm{Ba}, \mathrm{Rb}, \mathrm{Sr}$ heading above for values.
} 
Table 2. Additional data for analyzed muscovites

[Leaders (---), not determined

\begin{tabular}{|c|c|c|c|c|c|c|}
\hline \multirow[b]{2}{*}{ Sample No.---- } & \multicolumn{4}{|c|}{ Muscovites from aplites } & \multirow{2}{*}{$\frac{\text { Muscovites from }}{392-\text { DL }-67}$} & \multirow{2}{*}{$\frac{\text { quartz veins }}{396-\mathrm{DL}-67}$} \\
\hline & $119-M W-60$ & $199-M W-61$ & $121-M W-60$ & $245-M W-60$ & & \\
\hline \multicolumn{7}{|l|}{ Optical properties: } \\
\hline $\begin{array}{l}\beta \text { index } \\
2 \underline{V}(-)\end{array}$ & $\begin{array}{l}1.606 \\
37^{\circ}\end{array}$ & $\begin{array}{l}1.600 \\
41^{\circ}\end{array}$ & -- & $\begin{array}{l}1.586 \\
42^{\circ}\end{array}$ & $\begin{array}{l}1.598 \\
39^{\circ}\end{array}$ & $\begin{array}{l}1.582 \\
44^{\circ}\end{array}$ \\
\hline \multicolumn{7}{|l|}{ Density: } \\
\hline $\begin{array}{l}\text { Observed }( \pm 0.01) \\
\text { Calculated }\end{array}$ & $\begin{array}{l}2.89 \\
2.897\end{array}$ & $\begin{array}{l}2.88 \\
2.889\end{array}$ & 2.88 & 2.87 & $\begin{array}{l}2.86 \\
2.865\end{array}$ & $\begin{array}{l}2.86 \\
2.856\end{array}$ \\
\hline $\begin{array}{l}\text { Cel1 parameters obs } \\
\frac{\mathrm{a}}{\mathrm{b}}( \pm 0.005 \AA) \\
\frac{\mathrm{c}}{\mathrm{c}}( \pm 0.010 \AA \mathrm{\AA}) \\
\bar{\beta}\left( \pm 5.0^{\prime}\right) \\
\text { Volume }\left( \pm 1.0 \AA^{3}\right)\end{array}$ & $\begin{array}{l}\text { erved: } \\
\qquad \begin{array}{l}5.212 \\
9.050 \\
20.034 \\
95^{\circ} 45^{\prime} \\
940.2\end{array}\end{array}$ & $\begin{array}{l}5.201 \\
9.031 \\
20.056 \\
95^{\circ} 49^{\prime} \\
937.3\end{array}$ & $\begin{array}{l}--- \\
--- \\
--- \\
--- \\
---\end{array}$ & $\begin{array}{l}--- \\
--- \\
--- \\
--- \\
---\end{array}$ & $\begin{array}{l}5.207 \\
9.030 \\
20.050 \\
95^{\circ} 48^{\prime} \\
938.0\end{array}$ & $\begin{array}{l}5.200 \\
9.031 \\
20.053 \\
95^{\circ} 45^{\prime} \\
937.0\end{array}$ \\
\hline $\begin{array}{l}\text { Ce1l volume calcula } \\
\text { Volume }\left(\AA^{3}\right)\end{array}$ & $\begin{array}{l}\text { ted: } \\
\qquad 945.68\end{array}$ & 939.75 & --- & -- & 933.01 & 929.16 \\
\hline $\begin{array}{l}\text { Stable isotope data } \\
\partial^{18} 0 \text {, permil } \\
\delta D, \text { permil }\end{array}$ & $\begin{array}{l}(\text { SMOW }): \\
--- \\
-135.3\end{array}$ & $\begin{array}{l}9.9 \\
-123.3\end{array}$ & -- & $\begin{array}{l}8 \cdot 0 \\
-61 \cdot 5\end{array}$ & $\begin{array}{l}9.9 \\
-64.6\end{array}$ & $\begin{array}{l}11.9 \\
-66.8\end{array}$ \\
\hline $\mathrm{K}-\mathrm{Ar}$ age $(\mathrm{m} \cdot \mathrm{y} \cdot)^{\mathrm{l}--}$ & $34 \pm 1$ & $53.9 \pm 1.5$ & $31 \pm 2$ & $247.9 \pm 2.0$ & $156 \pm 6$ & $72.1 \pm 2.2$ \\
\hline Coexisting minerals & $\begin{array}{l}\text { Quartz } \\
\text { Feldspar } \\
\text { Garnet } \\
\text { Fluorite } \\
\text { (sparsę) } \\
\text { Apatite } \\
\text { (sparse) }\end{array}$ & $\begin{array}{l}\text { Quartz } \\
\text { Feldspar } \\
\text { Garnet } \\
\text { Fluorite } \\
\text { (sparse) } \\
\text { Columbite- } \\
\text { tantalite } \\
\text { (trace) }\end{array}$ & $\begin{array}{l}\text { Quartz } \\
\text { Feldspar } \\
\text { Garnet } \\
\text { Traces of } \\
\text { gahnite, } \\
\text { apatite } \\
\text { columbite- } \\
\text { tantalite }\end{array}$ & $\begin{array}{l}\text { Quartz } \\
\text { Feldspar } \\
\text { Garnet } \\
\text { Traces of } \\
\text { gahnite, } \\
\text { monazite, } \\
\text { columbite- } \\
\text { tantalite, } \\
\text { zircon }\end{array}$ & $\begin{array}{l}\text { Quartz } \\
\text { Apatite } \\
\text { (sparse) }\end{array}$ & $\begin{array}{l}\text { Quartz } \\
\text { Wolframite } \\
\text { (sparse) }\end{array}$ \\
\hline
\end{tabular}

${ }^{1} \mathrm{~K}$-Ar age data from Lee and others (1970).

$2 \mathrm{~K}-\mathrm{Ar}$ age data from Lee and others (1980); uranium-lead isotopic age of coexisting zircon is $75 \pm 9 \mathrm{Ma}$ (unpublished data).

${ }^{3}$ Analytical data for apatite given by Lee and others (1973). 


\section{Muscovites from Aplites}

Muscovite 119-MW-60 is from an isolated mass of Tertiary aplite apparently squeezed up between two faults by stresses related to late movement on the Snake Range décollement (Lee and Van Loenen, 1971). This aplitic muscovite is notably high in $\mathrm{Fe}_{2} \mathrm{O}_{3}, \mathrm{FeO}$, and $\mathrm{MgO}$ (table 1), and as such it represents solid solution between muscovite and celadonite and is phengitic (Foster, 1956). Muscovites from the two-mica granites of the area are also phengitic (Lee and others, 1981).

Three of the analyzed muscovites were recovered from aplites that intrude the unusual Cretaceous two-mica granites of northeastern Nevada that bear muscovite phenocrysts (Lee and others, 1981). Samples 199-MW-61 and 121-MW-60 are from the Pole Canyon-Can Young Canyon area of the southern Snake Range, and sample 245-MW-60 is from the Kern Mountains, about $83 \mathrm{~km}$ north of the other two. These three muscovites are chemically similar except that number $121-\mathrm{MW}-60$ is rather rich in $\mathrm{Na}_{2} \mathrm{O}$ (1.29 weight percent), equivalent to about 16.8 mol percent of paragonite. The K-Ar ages determined for these muscovites are spuriously low for reasons discussed by Lee and others $(1970,1980)$.

\section{Muscovites from Quartz Veins}

Samples 392-DL-67 and 396-DL-67 were collected about $3 \mathrm{~km}$ apart, from a set of quartz veins that strikes N. $60^{\circ}-75^{\circ} \mathrm{E}$. and dips $60^{\circ}-90^{\circ} \mathrm{SE}$., just north of Williams Canyon on the west side of the southern Snake Range (Lee and Van Loenen, 1971, pl. 1). These quartz veins are present within the Jurassic (155 Ma) Snake Creek-Williams Canyon intrusion (Lee and Christiansen, 1983). Some of the larger veins in the set are more than $3 \mathrm{~m}$ wide and are continuously exposed over a horizontal distance of $300 \mathrm{~m}$ or more. A few (one in particular) of the largest of these quartz veins were worked for wolframite at the Hub mine during World War I. During 1911-1916 the Hub district produced 9,058 tons of wolframite concentrate valued at $\$ 672,353$ (Couch and Carpenter, 1943).

Sample 392-DL-67 is from a quartz vein about $10 \mathrm{~cm}$ wide, and sample 396-DL-67 is from a bull quartz vein about $1 \mathrm{~m}$ wide. The two muscovites gave $\mathrm{K}-\mathrm{Ar}$ ages of $156 \pm 6$ and $72.1 \pm 2.2 \mathrm{Ma}$, respectively. The $156-\mathrm{Ma}$ date is in good agreement with the age (155 Ma) determined for the host intrusion. It was suggested (Lee and others, 1970, p. D97) that the 72.1-Ma date determined for 396-DL-67 might result from loss of argon due to late slippage along the quartz vein from which the sample was collected. However, more recently (Lee and Christiansen, 1983), it has become apparent that there was also a Cretaceous ( $79 \mathrm{Ma}$ ) magmatic event in the area. Thus it is possible that muscovites $392-$ DL-67 and 396-DL-67 actually formed at very different times, even though the host veins have the same attitude. Therefore the wolframite mineralization at the Hub mine may be Late Cretaceous in age, much younger than the Late Jurassic host intrusion.

The stable-isotope data (table 2) are consistent with the idea that formation of the veins sampled might have been related to one or more of the magmatic episodes recognized in the area. The $\delta^{18} \mathrm{O}$ values of the muscovites are near the $\delta^{18} \mathrm{O}$ value for magmatic water postulated by Taylor (1977), and their $\delta \mathrm{D}$ values are near the estimated $\delta \mathrm{D}$ of "juvenile" water (Sheppard and Epstein, 1970).

Muscovite 392-DL-67 contains somewhat more $\mathrm{Fe}_{2} \mathrm{O}_{3}, \mathrm{MgO}, \mathrm{Na}_{2} \mathrm{O}$, and $\mathrm{BaO}$ and much less fluorine than does 396-DL-67. Indeed, to our knowledge, muscovite 396-DL-67 contains more fluorine (1.90 weight percent) than any natural muscovite mentioned in the literature. This fluorine-rich muscovite is present with minor amounts of wolframite.

The high fluorine content of muscovite 396-DL-67 is not readily apparent from the physical properties listed in table 2, but it does seem to have an effect on the color of the mineral. In grains of $0.10-\mathrm{mm}$ size, the bulk mineral has a chalky white color. A bulk fraction of the same size grains of muscovite 392-DL-67 is brownish gray in color, but as noted this muscovite also has slightly higher $\mathrm{Fe}_{2} \mathrm{O}_{3}$ and $\mathrm{MgO}$ contents than the fluorine-rich 396-DL-67.

\section{REFERENCES CITED}

Couch, B.F., and Carpenter, J.A., 1943, Nevada's metal and mineral production (1859-1940, inclusive): University of Nevada Bulletin, Geology and Mining Series 38, 159 p.

Ernst, W.G., 1963, Significance of phengitic micas from lowgrade schists: American Mineralogist, v. 48, p. 1357-1373.

Evans, H.T., Jr., Appleman, D.E., and Handwerker, D.S., 1963, The least squares refinement of crystal unit cells with powder diffraction data by an automatic computer indexing method: American Crystallographic Association Program and Abstracts 1963 Annual Meeting, p. 42-43.

Foster, M.D., 1956, Correlation of dioctahedral potassium micas on the basis of their charge relations: U.S. Geological Survey Bulletin 1036-D, p. 57-67.

Friedman, Irving, and O'Neil, J.R., 1977, Compilation of stable isotope fractionation factors of geochemical interest, in Fleischer, Michael, ed., Data of geochemistry, 6th edition: U.S. Geological Survey Professional Paper 440-KK, 12 p.

Hose, R.K., and Blake, M.C., 1976, Geology of White Pine County, Nevada: Nevada Bureau of Mines and Geology Bulletin 85, pt. 1, p. 1-35.

Jackson, E.D., Stevens, R.E., and Bowen, R.W., 1967, A computer-based procedure for deriving mineral formulas from mineral analyses, in Geological Survey research 1967 : U.S. Geological Survey Professional Paper 575-C, p. C23-C31.

Muscovites of White Pine County, Nevada 
Lee, D.E., and Christiansen, R.L., 1983, The granite problem as exposed in the southern Snake Range, Nevada: Contributions to Mineralogy and Petrology, v. 83, p. 99-116.

Lee, D.E., and Doering, W.P., 1974, Barium in hybrid granitoid rocks of the southern Snake Range, Nevada: U.S. Geological Survey Journal of Research, v. 2, p. 671-675.

1980, Rubidium and strontium in hybrid granitoid rocks, southern Snake Range, Nevada: U.S. Geological Survey Professional Paper 1158-A, p. 1-7.

Lee, D.E., Kistler, R.W., Friedman, Irving, and Van Loenen, R.E., 1981, Two-mica granites of northeastern Nevada: Journal of Geophysical Research, v. 86, no. B11, p. 10607-10616.

Lee, D.E., Marvin, R.F., and Mehnert, H.H., 1980, A radiometric age study of Mesozoic-Cenozoic metamorphism in eastern White Pine County, Nevada, and nearby Utah: U.S. Geological Survey Professional Paper 1158-C, p. 17-28.

Lee, D.E., Marvin, R.F., Stern, T.W., and Peterman, Z.E., 1970, Modification of potassium-argon ages by Tertiary thrusting in the Snake Range, White Pine County, Nevada, in Geological Survey research 1970: U.S. Geological Survey Professional Paper 700-D, p. D196-D206.

Lee, D.E., and Van Loenen, R.E., 1971, Hybrid granitoid rocks of the southern Snake Range, Nevada: U.S. Geological Survey Professional Paper 668, 48 p.

Lee, D.E., Van Loenen, R.E., and Mays, R.E., 1973, Accessory apatite from hybrid granitoid rocks of the southern Snake Range, Nevada: U.S. Geological Survey Journal of Research, v. 1, no. 1 , p. 89-98.

Peck, L.C., 1964, Systematic analysis of silicates: U.S. Geological Survey Bulletin 1170, 89 p.

Sheppard, S.M.F., and Epstein, Samuel, 1970, D/H and ${ }^{18} \mathrm{O} /{ }^{16} \mathrm{O}$ ratios of minerals of possible mantle or lower crustal origin: Earth and Planetary Science Letters, v. 9, p. 232-239.

Taylor, H.P., Jr., 1977, Water-rock interactions and the origin of $\mathrm{H}_{2} \mathrm{O}$ in granitic batholiths: Journal of the Geological Society of London, v. 133, p. 509-558. 
Chapter D

Chemical and Stable-Isotope Data for Micas from Metaclastic Rocks of Eastern White Pine County, Nevada

\author{
By D.E. LEE, R.E. VAN LOENEN, \\ E.L.M. BRANDT, and J.D. GLEASON
}

Micas related to movement on thrust faults

have $\delta \mathrm{D}$ values well below the "normal" range

U.S. GEOLOGICAL SURVEY BULLETIN 1694

CONTRIBUTIONS TO MINERAL RESOURCES RESEARCH, 1984 


\title{
CONTENTS
}

\author{
Abstract $\mathbf{4 3}$ \\ Introduction $\mathbf{4 3}$ \\ Analytical techniques $\mathbf{4 3}$ \\ Samples 44 \\ Chemical analyses 44 \\ Stable-isotope data $\mathbf{4 9}$ \\ Conclusions $\mathbf{5 1}$ \\ References cited $\mathbf{5 3}$
}

\section{FIGURES}

1. Index map showing localities of mica samples analyzed $\mathbf{4 5}$

2. Camera lucida drawings of four quartzite samples from which recovered micas were analyzed 48

3. Plot of $\delta^{18} \mathrm{O}$ versus $\delta \mathrm{D}$ values for analyzed micas from metaclastic rocks of eastern White Pine County, Nevada 52

\section{TABLES}

1. Analytical data for white micas recovered from late Precambrian and Early Cambrian metasedimentary rocks $\mathbf{4 6}$

2. Mineral content of the rocks from which the analyzed micas were recovered 49

3. Properties of analyzed white micas $\mathbf{5 0}$

4. Analytical data for biotites recovered from late Precambrian and Early Cambrian metasedimentary rocks 51

5. Stable-isotope data and K-Ar ages for micas recovered from late Precambrian and Early Cambrian metasedimentary rocks $\mathbf{5 2}$ 


\title{
Chemical and Stable-Isotope Data for Micas from Metaclastic Rocks of Eastern White Pine County, Nevada
}

\author{
By D.E. Lee, R.E. Van Loenen, E.L.M. Brandt, and J.D. Gleason
}

\begin{abstract}
Regional thrust faults in eastern White Pine County, Nevada, have moved Paleozoic sedimentary rocks over late Precambrian and Early Cambrian metaclastic rocks. The lower plate metaclastic rocks are exposed over thousands of square kilometers and were derived from a deeply weathered Proterozoic crystalline terrane.

Metamorphic micas recovered from the late Precambrian and Early Cambrian lower plate rocks have yielded Tertiary KAr ages that generally relate to the time of latest movement on the overlying décollement. Chemical and stable-isotope data are presented for these same metamorphic micas. The most remarkable of the white micas analyzed contains 2.91 weight percent $\mathrm{Na}_{2} \mathrm{O}$, equivalent to $38 \mathrm{~mol}$ percent paragonite. Many of the white micas and biotites studied have $\delta \mathrm{D}$ values well below the "normal" range of -50 to -85 permil, possibly as a result of isotopic exchange with hydrothermal-meteoric waters circulating near the regional thrust faults. However, the fairly "normal" $\delta^{18} \mathrm{O}$ values of the analyzed micas imply rather low water:rock ratios during the isotopic exchange.
\end{abstract}

\section{INTRODUCTION}

In eastern White Pine County, Nev., regional thrust faults have moved Paleozoic sedimentary rocks over late Precambrian and Early Cambrian metaclastic rocks. Plutons ranging in age from Jurassic to Tertiary are also present in lower plate rocks.

Lower plate quartzitic rocks are exposed over thousands of square kilometers. Previous studies have focused on the chemical composition of these quartzites (Lee, Van Loenen, and others, 1980) and on the K-Ar ages of their constituent micas (Lee and others, 1970; Lee, Marvin, and Mehnert, 1980). We have also obtained U-Th-Pb isotopic ages $(78 \pm 9 \mathrm{Ma})$ for metamorphic monazite and recrystallized detrital zircon from lower plate metaclastic rocks that have been subjected to staurolite-kyanite-grade metamorphism (Lee and others, 1981, and unpub. data).

Two main conclusions have been drawn from these earlier studies. First, the original miogeosynclinal shelf sediments were derived from a deeply weathered, Early
Proterozoic crystalline terrane. These sediments were mixtures of (1) sand with a fair degree of mineralogical maturity and (2) argillaceous materials. In most cases the bulk composition of the argillaceous material apparently was appropriate for the crystallization of metamorphic micas under conditions of metamorphism that were essentially isochemical, except for depletion of pore fluids.

The second main conclusion drawn from the earlier studies is that the K-Ar ages (commonly Tertiary) obtained for the metamorphic micas recovered from lower plate (late Precambrian and Early Cambrian) metasedimentary rocks generally relate to the time of latest movement on the overlying décollement (Lee and others, 1970; Lee, Marvin, and Mehnert, 1980). In other words, these metamorphic micas were partially to totally degassed by strain heating related to late movement on the overlying décollement and therefore give a maximum age for the time of that movement. Samples collected just below the sole of the décollement have been degassed most completely and so give K-Ar ages most representative of the time of latest movement.

Despite past efforts, however, two essential questions remain with regard to any one of the micas recovered from the lower plate metasedimentary rocks: (1) If the mica was only degassed at, say, $20 \mathrm{Ma}$, then when did it first crystallize from the argillaceous material in the original clastic sediment? (2) Did the mica re-equilibrate chemically to the conditions of the most recent event during which it was degassed?

Here we present chemical and stable-isotope data for selected micas recovered from lower plate metaclastic rocks of eastern White Pine County, Nevada. We have previously reported $\mathrm{K}-\mathrm{Ar}$ ages for most of these same micas (Lee and others, 1970; Lee, Marvin, and Mehnert, 1980), and we emphasize that all data reported for a given sample were determined on splits of the same mineral fraction.

\section{ANALYTICAL TECHNIQUES}

The micas were prepared for analysis by methods described by Lee and Van Loenen (1970, p. D198). Briefly, 
the final purification was by centrifuging in densityadjusted mixtures of methylene iodide and bromoform and by repeated passes through the magnetic separator. Generally the muscovites fractionated over a very narrow density range, indicating a similarly small range of composition of the mineral in the rock. On the other hand, each biotite fractionated over a rather large density range, as indicated in table 3 , and the recovery of a homogeneous sample for analysis was difficult. Similar difficulties were encountered in the purification of the biotites discussed by Lee and Van Loenen (1970), who have described the problem in some detail.

Major elements were determined by the chemical methods described by Peck (1964) and calculated on the basis of $24(\mathrm{O}, \mathrm{OH}, \mathrm{F}, \mathrm{Cl})$ to the general mica formula $\mathrm{X}_{2} \mathrm{Y}_{4-6} \mathrm{Z}_{8} \mathrm{O}_{20}(\mathrm{OH}, \mathrm{F}, \mathrm{Cl})_{4}$, using the computer program described by Jackson and others (1967). Calculated values for density and cell volume were determined by the same program.

Quantitative barium, rubidium, and strontium values were determined by $\mathrm{X}$-ray fluorescence. The methods for barium and for rubidium and strontium are described by Lee and Doering (1974 and 1980, respectively). Results of semiquantitative spectrographic analyses are based on their identity with geometric brackets whose boundaries are $1.2,0.83,0.56,0.38,0.26$, $0.18,0.12$, and so forth, and are reported arbitrarily as midpoints of these brackets: $1,0.7,0.5,0.3,0.2,0.15$, and 0.1 , respectively. The precision of a reported value is approximately plus or minus one bracket at 68 percent confidence or two brackets at 95 percent confidence.

Stable-isotope data are based on SMOW, standard mean ocean water (Friedman and O'Neil, 1977).

A given sample number refers to the whole rock and to each of the mineral fractions recovered from that rock.

\section{SAMPLES}

Sample localities are shown in figure 1. Exact coordinates are listed and the field setting of each of these samples is described by Lee, Marvin, and Mehnert (1980).

Some representative textures are shown in figure 2. Sample 503 was collected from lower plate rocks on the northwestern flank of the northern Snake Range. The quartz grains show evidence of pronounced strain and recrystallization, with sutured contacts except where shielded by mica. The orientation of the micas is determined mainly by the outlines of the original detrital quartz grains. Samples 505 and 506 (not shown) are similar to 503, but in sample 506 a directional element is evident in thin section.

Sample $555(\mathrm{~K}$-Ar age, $141 \pm 5 \mathrm{Ma})$ is unique among those analyzed in that it does not appear to be spatially related to any thrust fault. It was collected at an elevation of 3,440 $\mathrm{m}$ in the Wheeler Peak area of the southern Snake Range. K-Ar ages determined on samples from the Wheeler Peak area show no relation to present altitude, position within the stratigraphic section, or distance below any hypothetical but now-eroded thrust fault. The original argillaceous cement in sample 555 has crystallized to an extremely fine grained muscovite surrounding the detrital quartz, which shows no evidence of strain or recrystallization. These textural features may be the result of a very low grade static or load metamorphism (Lee, Marvin, and Mehnert, 1980).

Sample site 561 probably is not more than a few meters below the sole of the Snake Range décollement. The quartz is completely recrystallized and drawn out to express a planar element approximately parallel with the present surface and presumably with the overlying thrust fault. The micas are aligned in the same plane.

Sample 569 was collected from a shaly unit within quartzite. About 23 percent of the rock is a very homogeneous, well-crystallized metamorphic muscovite that shows no preferred orientation.

\section{CHEMICAL ANALYSES}

All the white micas analyzed (table 1 ) are $2 \mathrm{M}_{1}$ micas. Many are high in silica, low in alumina, and contain appreciable amounts of $\mathrm{FeO}$ and $\mathrm{MgO}$. As such, they represent solid solution between muscovite and celadonite and are phengites (Foster, 1956). Most of the white micas that contain notable amounts of $\mathrm{Fe}_{2} \mathrm{O}_{3}$ (table 1) coexist with magnetite or hematite. Those highest in $\mathrm{Fe}_{2} \mathrm{O}_{3}$ (numbers 547 and 548) coexist with a mineral that is part of the metamorphic fabric and is tentatively identified as maghemite. The mineral content of the rocks from which the analyzed micas were recovered is summarized in table 2.

One of the micas in the literature most similar to some of those in table 1 comes from a very similar geologic setting. It is the "iron-rich muscovitic mica" from the Grandfather Mountain area, North Carolina (Foster and others, 1960). This same mica was referred to as a "phengite" by Ernst (1963, p. 1358) and as a "phengitic mica" by Velde (1965, p. 906). The analysis, as corrected for impurities and adjusted to 100 weight percent (Foster and others, 1960, p. 845), is $\mathrm{SiO}_{2}, 47.62$; $\mathrm{Al}_{2} \mathrm{O}_{3}, 24.74 ; \mathrm{Fe}_{2} \mathrm{O}_{3}, 8.11 ; \mathrm{FeO}, 2.55 ; \mathrm{MgO}, 1.88 ; \mathrm{MnO}$, $0.08 ; \mathrm{Na}_{2} \mathrm{O}, 0.11 ; \mathrm{K}_{2} \mathrm{O}, 10.72 ; \mathrm{F}, 0.14$; and $\mathrm{H}_{2} \mathrm{O}, 4.05$. The mica analyzed was recovered from a late Precambrian or Early Cambrian micaceous arkosic quartzite exposed below the thrust surface in the Grandfather Mountain area. Similar mica is present in most of the metamorphosed arkoses and arkosic quartzites exposed both above and below the thrust (Foster and others, 1960, 


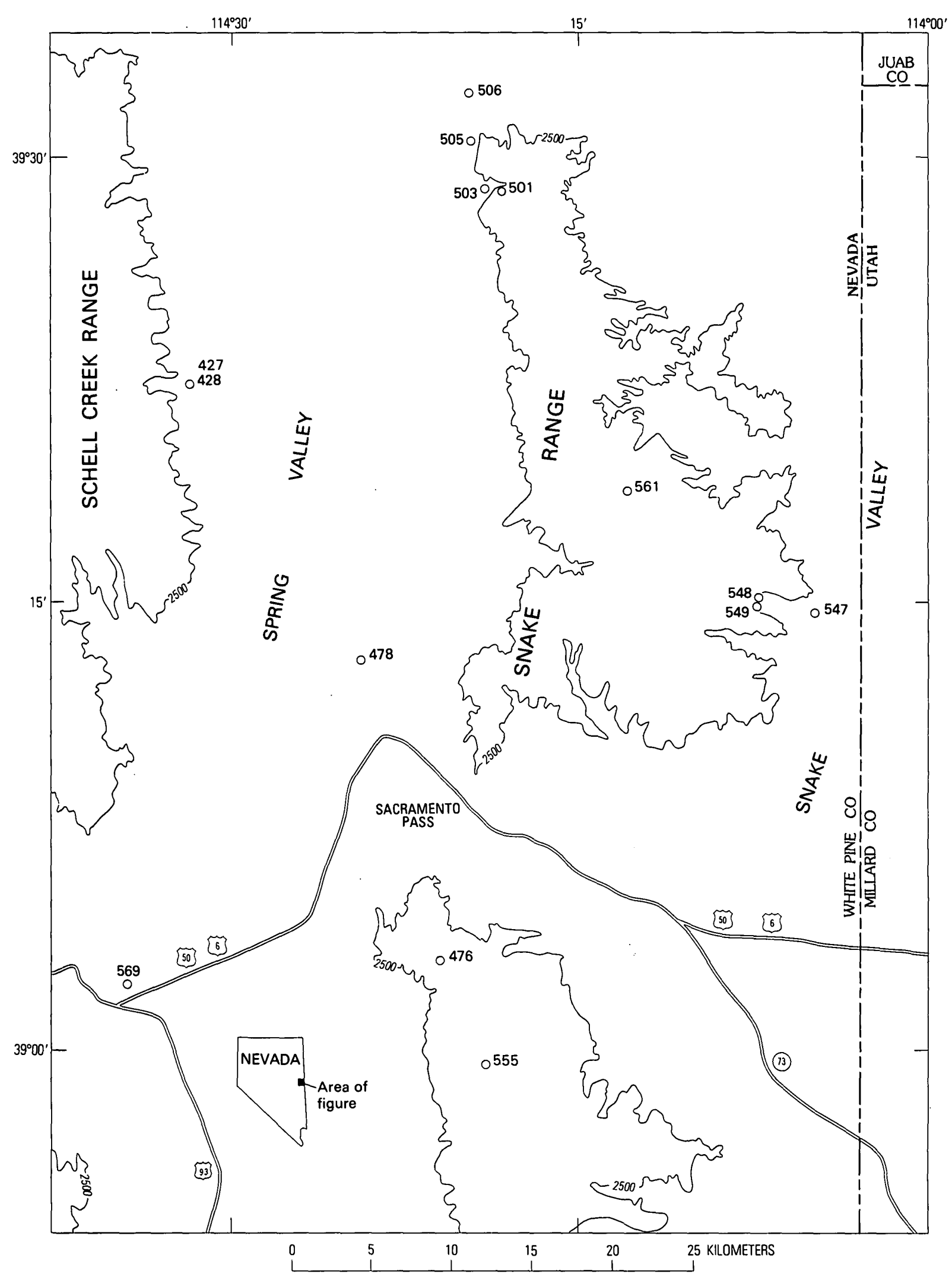

Figure 1. Localities of mica samples analyzed. Precise latitudes and longitudes of localities are listed in Lee, Marvin, and Mehnert (1980). Sample locality 511 (not shown) is from the Toana Range about $150 \mathrm{~km}$ north of map area. 
Table 1. Analytical data for white micas recovered from late Precambrian and Early Cambrian metasedimentary rocks [Chemical analyses by E.L. Munson Brandt. Quantitative Ba, Rb, and Sr analyses by W.P. Doering. Semiquantitative spectrographic analyses

\begin{tabular}{|c|c|c|c|c|c|c|c|}
\hline Sample No.- & -1427 & $1_{428}$ & $1_{476}$ & 478 & 501 & 503 & 505 \\
\hline \multicolumn{8}{|c|}{ Chemical analyses (weight percent) } \\
\hline $\mathrm{SiO}_{2}$ & 46.40 & 45.86 & 49.42 & 47.23 & 46.97 & 45.99 & 46.45 \\
\hline $\mathrm{Al}_{2} \mathrm{O}_{3}$ & 29.60 & 33.82 & 29.62 & 28.52 & 30.10 & 30.24 & 31.04 \\
\hline $\mathrm{Fe}_{2} \mathrm{O}_{3}$ & 4.35 & 1.69 & 2.72 & 5.41 & 2.24 & 4.31 & 2.39 \\
\hline $\mathrm{FeO}$ & 1.48 & 1.45 & 1.87 & .94 & 1.85 & 1.62 & 2.57 \\
\hline $\mathrm{MgO}$ & 1.53 & .76 & 1.52 & 1.62 & 1.88 & 1.02 & 1.17 \\
\hline $\mathrm{CaO}$ & .05 & .01 & .00 & .00 & .00 & .00 & .00 \\
\hline $\mathrm{Na}_{2} \mathrm{O}$ & .42 & .55 & --- & .16 & .39 & .37 & .30 \\
\hline $\mathrm{K}_{2} \mathrm{O}_{+}$ & 10.50 & 10.36 & $-\infty$ & 10.99 & 10.79 & 10.86 & 11.03 \\
\hline $\mathrm{H}_{2} \mathrm{O}^{+}$ & 4.37 & 4.35 & -- & 4.16 & 4.05 & 4.07 & 4.07 \\
\hline $\mathrm{H}_{2}^{2} \mathrm{O}^{-}$ & .05 & .05 & .06 & .02 & .03 & .01 & .01 \\
\hline $\mathrm{TiO}_{2}$ & .75 & .33 & .58 & .76 & 1.40 & 1.10 & .50 \\
\hline $\mathrm{P}_{2} \mathrm{O}_{5}^{2}$ & .05 & .05 & --- & .00 & .00 & .00 & .00 \\
\hline $\mathrm{MnO}$ & .02 & .01 & --- & .02 & .02 & .02 & .02 \\
\hline $\mathrm{C} 1$ & .00 & .01 & --- & .01 & .00 & .01 & .00 \\
\hline $\mathrm{F}$ & .07 & .13 & -- & .07 & .16 & .16 & .38 \\
\hline \multirow{2}{*}{$\begin{array}{l}\text { Subtotal } \\
\text { Less } 0\end{array}$} & 99.64 & 99.43 & 85.79 & 99.91 & 99.88 & 99.78 & 99.93 \\
\hline & .03 & .05 & -- & .03 & .07 & .07 & .16 \\
\hline Total & 99.61 & 99.38 & $-\cdots$ & 99.88 & 99.81 & 99.71 & 99.77 \\
\hline
\end{tabular}

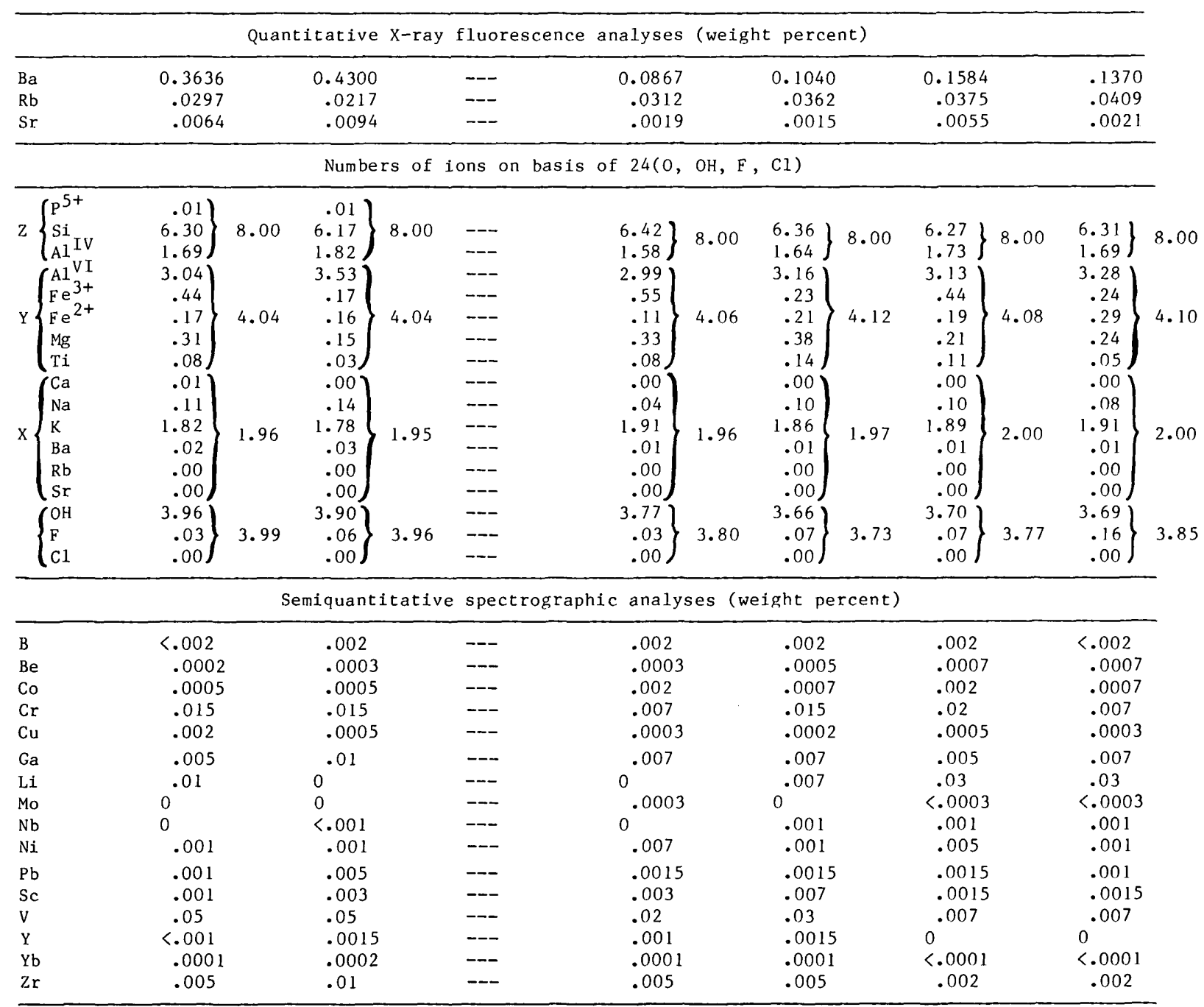

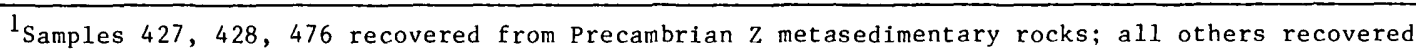
from Early Cambrian metasedimentary rocks. 
by L.A. Bradley. Leaders (---), not determined]

\begin{tabular}{|c|c|c|c|c|c|c|c|c|c|c|c|c|c|c|c|}
\hline 506 & & 511 & & 547 & & 548 & & 549 & & 2555 & & 561 & & 569 & \\
\hline \multicolumn{16}{|c|}{ Chemical analyses--Continued } \\
\hline 46.98 & & 45.76 & & 45.71 & & 45.56 & & 46.07 & & 51.89 & & 46.40 & & 47.05 & \\
\hline 31.21 & & 29.26 & & 30.38 & & 30.44 & & 36.20 & & 27.31 & & 30.53 & & 27.04 & \\
\hline 1.63 & & 5.23 & & 6.44 & & 6.49 & & 1.38 & & 4.38 & & 3.55 & & 5.87 & \\
\hline 1.70 & & 1.80 & & .56 & & .68 & & .58 & & .56 & & 1.21 & & 1.15 & \\
\hline 1.70 & & 1.17 & & .84 & & .66 & & .62 & & .80 & & 1.42 & & 2.03 & \\
\hline .00 & & .00 & & .03 & & .01 & & .01 & & .00 & & .00 & & .00 & \\
\hline .33 & & .36 & & .42 & & .32 & & 2.91 & & .19 & & .39 & & .27 & \\
\hline 11.02 & & 10.89 & & 10.69 & & 10.80 & & 7.12 & & 10.11 & & 10.69 & & 10.89 & \\
\hline 4.02 & & 4.08 & & 4.27 & & 4.25 & & 4.43 & & 3.62 & & 4.22 & & 4.02 & \\
\hline .00 & & .00 & & .02 & & .03 & & .05 & & .05 & & .01 & & .04 & \\
\hline .85 & & 1.02 & & .36 & & .44 & & .35 & & .67 & & 1.05 & & 1.30 & \\
\hline .00 & & .02 & & .01 & & --- & & .01 & & --- & & .01 & & .03 & \\
\hline .01 & & .02 & & .02 & & --- & & .00 & & -- & & .01 & & .03 & \\
\hline .01 & & .00 & & .01 & & .00 & & .01 & & .00 & & .00 & & .01 & \\
\hline .48 & & .35 & & .06 & & .04 & & .04 & & .05 & & .05 & & .08 & \\
\hline 99.94 & & 99.96 & & 99.82 & & 99.72 & & 99.78 & & 99.63 & & 99.54 & & 99.81 & \\
\hline .20 & & .15 & & .03 & & .02 & & .02 & & .02 & & .02 & & .03 & \\
\hline 99.74 & & 99.81 & & 99.79 & & 99.70 & & 99.76 & & 99.61 & & 99.52 & & 99.78 & \\
\hline \multicolumn{16}{|c|}{ Quantitative X-ray fluorescence analyses--Continued } \\
\hline .1353 & & .1017 & & .0984 & & --- & & .0843 & & .1134 & & .2140 & & .0855 & \\
\hline .0384 & & .0495 & & .0277 & & --- & & .0089 & & .0292 & & .0248 & & .0338 & \\
\hline .0093 & & .0018 & & .0058 & & --- & & .0456 & & .0022 & & .0274 & & .0017 & \\
\hline \multicolumn{16}{|c|}{ Numbers of ions on basis of $24(0, \mathrm{OH}, \mathrm{F}, \mathrm{Cl})$--Continued } \\
\hline 6.34 & & $6.26\}$ & & $6.22\}$ & & $6.24\}$ & & $6.08\}$ & & $6.48\}$ & & $6.29\}$ & & 6.44 & \\
\hline 1.66$\}$ & 8.00 & $\begin{array}{l}1.74 \\
1.74\end{array}$ & 8.00 & $\begin{array}{l}1.78 \\
1.78\end{array}$ & 8.00 & $1.76\}$ & 8.00 & $1.92\}$ & 8.00 & $\begin{array}{l}1.52 \\
1.52\end{array}$ & 8.00 & $\begin{array}{l}1.71 \\
1.71\end{array}$ & 8.00 & $1.56\}$ & 8.00 \\
\hline 3.31$)$ & & $2.98)$ & & 3.09 & & $3.11 j$ & & $3.71)$ & & $3.23 i$ & & $3.17 i$ & & $2.80 i$ & \\
\hline .17 & & .54 & & .66 & & .67 & & .14 & & .49 & & .36 & & .61 & \\
\hline .19$\}$ & 4.10 & $.21\rangle$ & 4.08 & .06 & 4.02 & .08 & 4.05 & .06 & 4.07 & $.07\}$ & 4.05 & .14 & 4.07 & .13 & 4.08 \\
\hline .34 & & .24 & & .17 & & .14 & & .12 & & .18 & & .29 & & .41 & \\
\hline .09 & & $.11)$ & & .04 & & $.05)$ & & $.04)$ & & .08 & & $.11)$ & & .13 & \\
\hline .00$)$ & & $.00 \mathrm{j}$ & & $.00)$ & & $.00)$ & & .001 & & .001 & & $.00 j$ & & $.00 i$ & \\
\hline .09 & & .10 & & .11 & & .09 & & .74 & & .06 & & .10 & & .07 & \\
\hline 1.90 & 2.00 & 1.90 & 2.02 & 1.86 & 1.98 & 1.89 & 1.98 & 1.20 & 1.95 & 1.90 & 1.97 & 1.85 & 1.96 & 1.90 & 1.98 \\
\hline .01 & 2.00 & .01 & 2.02 & .01 & 1.30 & -- & 1.90 & .01 & כצי 1. & .01 & 1.91 & .01 & 1.90 & .01 & 1.90 \\
\hline .00 & & .01 & & .00 & & --- & & .00 & & .00 & & .00 & & .00 & \\
\hline .00$)$ & & $.00)$ & & $.00 J$ & & $---\quad /$ & & $.00)$ & & $.00)$ & & $.00)$ & & $.00)$ & \\
\hline 3.62$)$ & & $3.72)$ & & $3.88)$ & & $3.88)$ & & $3.90)$ & & $3.57)$ & & $3.82\}$ & & 3.67 ) & \\
\hline $\left.\begin{array}{l}.21 \\
.00\end{array}\right\}$ & 3.83 & $\left.\begin{array}{l}.15 \\
.00\end{array}\right\}$ & 3.87 & $\left.\begin{array}{l}.03 \\
.00\end{array}\right\}$ & 3.91 & $\left.\begin{array}{l}.02 \\
.00\end{array}\right\}$ & 3.90 & $\left.\begin{array}{l}.02 \\
.00\end{array}\right\}$ & 3.92 & $\left.\begin{array}{l}.02 \\
.00\end{array}\right\}$ & 3.59 & $\left.\begin{array}{l}.02 \\
.00\end{array}\right\}$ & 3.84 & $\left.\begin{array}{l}.04 \\
.00\end{array}\right\}$ & 3.71 \\
\hline \multicolumn{16}{|c|}{ Semiquantitative spectrographic analyses--Continued } \\
\hline$<.002$ & & $<.002$ & & $<.002$ & & $<.002$ & & $<.002$ & & .003 & & .002 & & .003 & \\
\hline .001 & & .0015 & & .0002 & & .0002 & & .0003 & & .0005 & & .0005 & & .0003 & \\
\hline .001 & & .0007 & & .0007 & & .001 & & .0003 & & .001 & & .0007 & & .0015 & \\
\hline .007 & & .015 & & .003 & & .005 & & .015 & & .005 & & .015 & & .007 & \\
\hline .0002 & & .0003 & & .0002 & & .0002 & & .0003 & & .0003 & & .0001 & & .0002 & \\
\hline .005 & & .007 & & .007 & & .005 & & .007 & & .003 & & .003 & & .005 & \\
\hline .02 & & .02 & & 0 & & 0 & & 0 & & 0 & & .015 & & .005 & \\
\hline 0 & & $<.0003$ & & 0 & & 0 & & 0 & & 0 & & 0 & & & 0 \\
\hline .001 & & .0015 & & $<.001$ & & $<.001$ & & $<.001$ & & .015 & & $<.001$ & & $<.001$ & \\
\hline .0007 & & .002 & & .003 & & .003 & & $<.0005$ & & .002 & & .002 & & .003 & \\
\hline .0015 & & .0015 & & .0015 & & .001 & & .005 & & .001 & & .0015 & & 0 & \\
\hline .0015 & & .003 & & .001 & & .0015 & & .0015 & & .0015 & & .002 & & .002 & \\
\hline .015 & & .015 & & .007 & & .007 & & .02 & & .007 & & .015 & & .015 & \\
\hline 0 & & $<.001$ & & $<.001$ & & $<.001$ & & $<.001$ & & .003 & & $<.001$ & & .001 & \\
\hline$<.0001$ & & $<.0001$ & & $<.0001$ & & $<.0001$ & & $<.0001$ & & .0003 & & $<.0001$ & & .0001 & \\
\hline 0 & & .003 & & .001 & & .0015 & & .005 & & .015 & & .003 & & .007 & \\
\hline
\end{tabular}

${ }^{2}$ Phengite 555 analyzed contained 8 percent admixed quartz. Structural formula computed on quartzfree basis. 
p. 840). Thus, given the appropriate bulk composition, it appears that a thrust-fault environment is conducive to the crystallization of such micas.
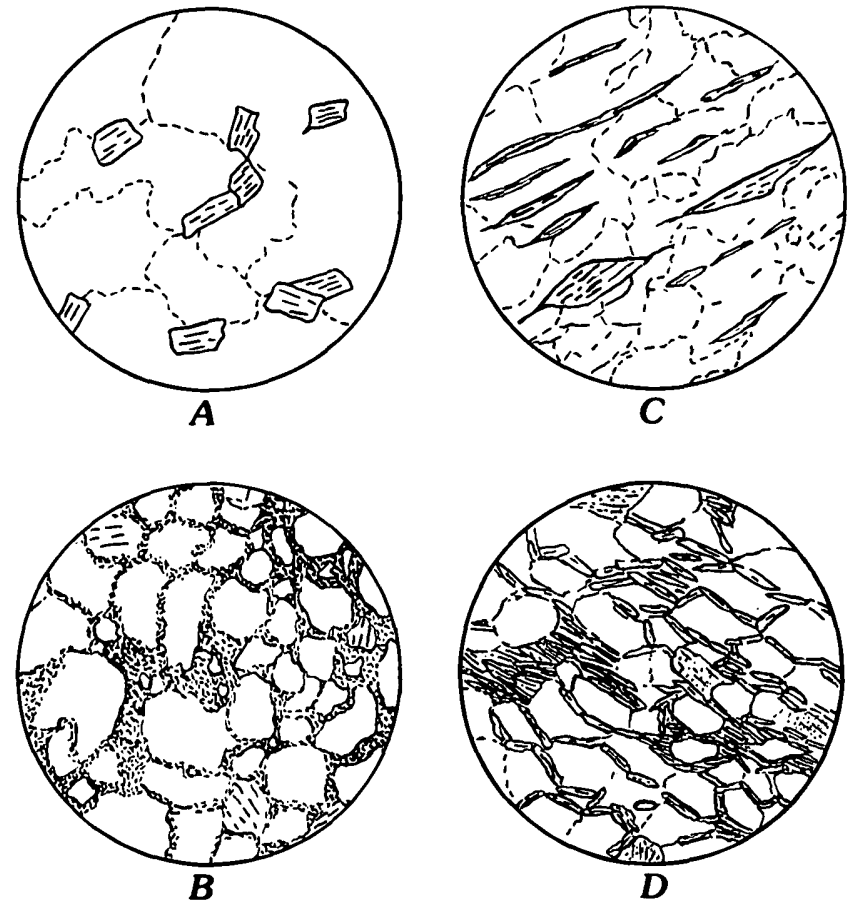

$1 \mathrm{~mm}$

Figure 2. Camera lucida drawings of four quartzite samples from which recovered micas were analyzed. $A$, sample 503: quartz and muscovite; $B$, sample 555: quartz, very fine grained muscovite, and three grains of feldspar; $C$, sample 561: quartz, muscovite, and a trace of biotite; $D$, sample 569: quartz, muscovite, and a few grains of potassium feldspar.

In calculation of the structural formulas (table 1), the $\mathrm{X}$-ray fluorescence values for $\mathrm{Ba}$ and $\mathrm{Rb}$ were used, as neither $\mathrm{BaO}$ nor $\mathrm{Rb}_{2} \mathrm{O}$ was sought by the chemist. The amounts of $\mathrm{BaO}$ present probably were lost during the gravimetric analyses, and in each case $\mathrm{Rb}_{2} \mathrm{O}$ probably was weighed with $\mathrm{K}_{2} \mathrm{O}$ (L.C. Peck, oral commun., 1970). The very small amounts of SrO present either were weighed with $\mathrm{CaO}$ or lost.

The structural formulas (table 1) are in rather good agreement with the ideal for dioctahedral mica: In all cases the octahedral occupancy is slightly greater than 4.00 , a feature common to most analyzed phengites (Mather, 1970, p. 258). The alkali contents tend to be slightly low, but agreement with the ideal 2.00 total is close considering the fact that a deficiency in the X-group totals is a persistent feature of muscovite analyses (Butler, 1967 , p. 253).

The physical properties of the white micas analyzed are listed in table 3 . Annealed fluorite was used as an internal standard for X-ray diffraction patterns which were used to give unit-cell parameters by least squares refine- ment. The standard error listed for each unit-cell parameter varies slightly from sample to sample, apparently because of slight differences in the quality of the $\mathrm{X}$-ray diffraction patterns. Agreement is good between the observed and calculated values for density and unitcell volume.

One of the most important results of this work is the discovery of a sodic muscovite $(549$, table 1$)$, which contains 2.91 weight percent $\mathrm{Na}_{2} \mathrm{O}$, equivalent to $38 \mathrm{~mol}$ percent paragonite. This sodic muscovite coexists only with quartz and biotite, except for trace amounts of chlorite, garnet, and staurolite. Paragonite as a discrete mineral is absent, and this sodic muscovite is present where one might expect the pair paragonite and low$\mathrm{Na}_{2} \mathrm{O}$ muscovite. The simplicity of this assemblage and the chemical data available for rock (Lee, Van Loenen, Brandt, and Doering, 1980), muscovite (table 1), and biotite (table 4) may help to direct future experimental work on the stability of sodic muscovite.

Biotites coexisting with four of the white micas in table 1 were recovered for analysis. As emphasized earlier, each of these biotites fractionated over a range of density when centrifuged in heavy liquids. Thus each of the analyses listed (table 4) applies to a bulk sample with the indicated density range. During work on these biotites, and on igneous biotites from the southern Snake Range, Nevada (Lee and Van Loenen, 1970), we have had chemical analyses made on the heavier and lighter biotite fractions present in different rock samples of about $1,000 \mathrm{~g}$ each. Our data show that in each sample the most significant compositional differences between the lighter and heavier biotite fractions involve the $\mathrm{FeO}$ and $\mathrm{Fe}_{2} \mathrm{O}_{3}$ contents. Invariably the heavier biotite fraction contains more $\mathrm{FeO}$ and less $\mathrm{Fe}_{2} \mathrm{O}_{3}$ than the lighter. For example, the $\mathrm{Fe}_{2} \mathrm{O}_{3}$ in sample 428 (table 4) is listed as 6.11 weight percent; the range might be about 5.2-7.0 weight percent $\mathrm{Fe}_{2} \mathrm{O}_{3}$. The equivalent range of $\mathrm{FeO}$ (22.72 weight percent) might be about 23.7-21.7 weight percent, on the basis of our experience.

X-ray powder patterns were obtained for a split of each of the analyzed biotites in table 4 . Oriented and disoriented mounts of each sample were scanned from $8^{\circ} 2 \theta$ to $65^{\circ} 2 \theta$ at a speed of $1 / 4^{\circ}$ per minute. However, we were unable to refine the measured $2 \theta$ values into meaningful unit-cell parameters, even by the method described by Dodge and others (1969, p. 263).

The $d_{060}$ peak provides a measure of $b$ (Wones, 1963). The (060) interplanar spacings of samples 428,501 , 506 , and 549 are $1.5428,1.5433,1.5424$, and $1.5410 \AA$, respectively. These results are in good agreement with those of Lee and Van Loenen (1970) and Dodge and others (1969), who found the (060) interplanar spacings of biotites to be rather constant within a narrow range regardless of composition.

The basal (005) interplanar spacings of samples 428, 501,506 , and 549 are 2.0145, 2.0077, 2.0085, and 2.0107 
Table 2. Mineral content of the rocks from which analyzed micas were recovered' [Measured in weight percent; Tr., trace]

\begin{tabular}{|c|c|c|c|c|c|c|c|}
\hline $\begin{array}{c}\text { Sample } \\
\text { No. }\end{array}$ & Quartz & $\begin{array}{l}\text { Plagio- } \\
\text { clase }\end{array}$ & $\begin{array}{l}\text { K-feld- } \\
\text { spar }\end{array}$ & $\begin{array}{c}\text { Musco- } \\
\text { vite }\end{array}$ & Biotite & Chlorite & other \\
\hline 427 & 92 & 2 & 0 & 4 & 2 & $\operatorname{Tr}$. & 0.05 magnetite. \\
\hline 428 & 69 & 2 & 0 & 21 & 8 & $\operatorname{Tr}$ & 0.25 ilmenite. \\
\hline 476 & 20 & 3 & 0 & 70 & 0 & $\operatorname{Tr}$. & Illite?, chlorite, 0.05 hematite. \\
\hline 478 & 70 & $<1$ & 4 & 26 & 0 & $(3)$ & 0.05 magnetite. \\
\hline 501 & 35 & 30 & 6 & 22 & 7 & & None noted. \\
\hline 503 & 89 & 0 & 0 & 11 & 0 & & Do. \\
\hline 505 & 69 & $<1$ & 5 & 25 & $<1$ & & Do. \\
\hline 506 & 90 & $<1$ & 0 & 9 & $<1$ & & Do. \\
\hline 511 & 82 & 0 & 10 & 8 & $\operatorname{Tr}$ & & 0.05 magnetite. \\
\hline 547 & 89 & $<1$ & $<1$ & 10 & 0 & & <1 "maghemite." \\
\hline 548 & 88 & 0 & 0 & 12 & 0 & & $<1$ "maghemite." \\
\hline 549 & 82 & 0 & 0 & 10 & 8 & $\operatorname{Tr}$ & Garnet, staurolite. \\
\hline 555 & 62 & 3 & 5 & 30 & 0 & & None noted. \\
\hline 561 & 94 & 0 & 0 & 6 & $\operatorname{Tr}$. & & Do. \\
\hline 569 & 63 & $<1$ & 10 & 27 & 0 & & 0.05 magnetite. \\
\hline
\end{tabular}

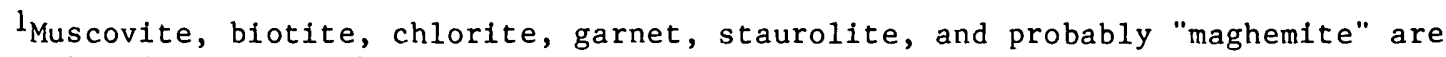
metamorphic in these rocks. All other minerals are detrital, though some quartz is recrystallized.

${ }^{2}$ Data for samples $427,501,511,555$, and 561 from unpublished notes. Data for all other samples from Lee, Van Loenen, Brandt, and Doering (1980).

3 Blank, no data.

$\AA$, respectively. Müller (1966), Dodge and others (1969), and Lee and Van Loenen (1970) all found the (005) spacing to decrease with increase of fluorine. Data from the present study are too few for a good check of this relation.

\section{STABLE-ISOTOPE DATA}

Stable-isotope data and previously reported $\mathrm{K}-\mathrm{Ar}$ ages are presented (table 5) for most of the chemically analyzed biotites. Taylor (1977) has emphasized that metamorphic rocks with $\delta \mathrm{D}$ values outside the "normal" range of -50 to -85 permil tend to be confined to unique geologic environments. Taylor has also noted that lowering of $\delta \mathrm{D}$ values commonly correlates with resetting of $\mathrm{K}-\mathrm{Ar}$ ages. The $\mathrm{K}-\mathrm{Ar}$ ages of our micas have been reset, and many of them have $\delta \mathrm{D}$ well below the "normal" range (table 5; fig. 3 ).

Frey and others (1976, p. 173) and Taylor (1977, p. 511) found $\Delta \mathrm{D}$ muscovite-biotite values in the range 15-35 permil, compatible with an equilibrium interpreta- tion (Suzuoka and Epstein, 1976). Of the four white mica-biotite pairs included in our study (table 5; fig. 3), three have $\Delta D$ values exceeding 50 permil, and one (428) has the very high value of 64 permil. On the other hand, our results are similar to those in the studies just cited in that white mica always has heavier isotopic values than biotite where the two coexist. Also the slopes of the lines connecting the white mica-biotite pairs (fig. 3 ) are similar to the slopes of such lines based on the data of Frey and others (1976, p. 173). Thus, although the isotopic compositions of our samples vary over a wide range of values, apparently some sort of equilibrium relation was reached between each of the white mica-biotite pairs.

The deuterium contents of natural waters can vary much from place to place and from time to time (Friedman, 1953; Friedman and others, 1964). Thus the pore waters present in the argillaceous sands may have differed from one body of sediment to another. Also, the isotopic composition of the hydrous minerals present in the original argillaceous materials may have differed from place to place. Thus we have no reason to assume that the original unmetamorphosed shelf sediments were pervaded by isotopically homogeneous waters. 


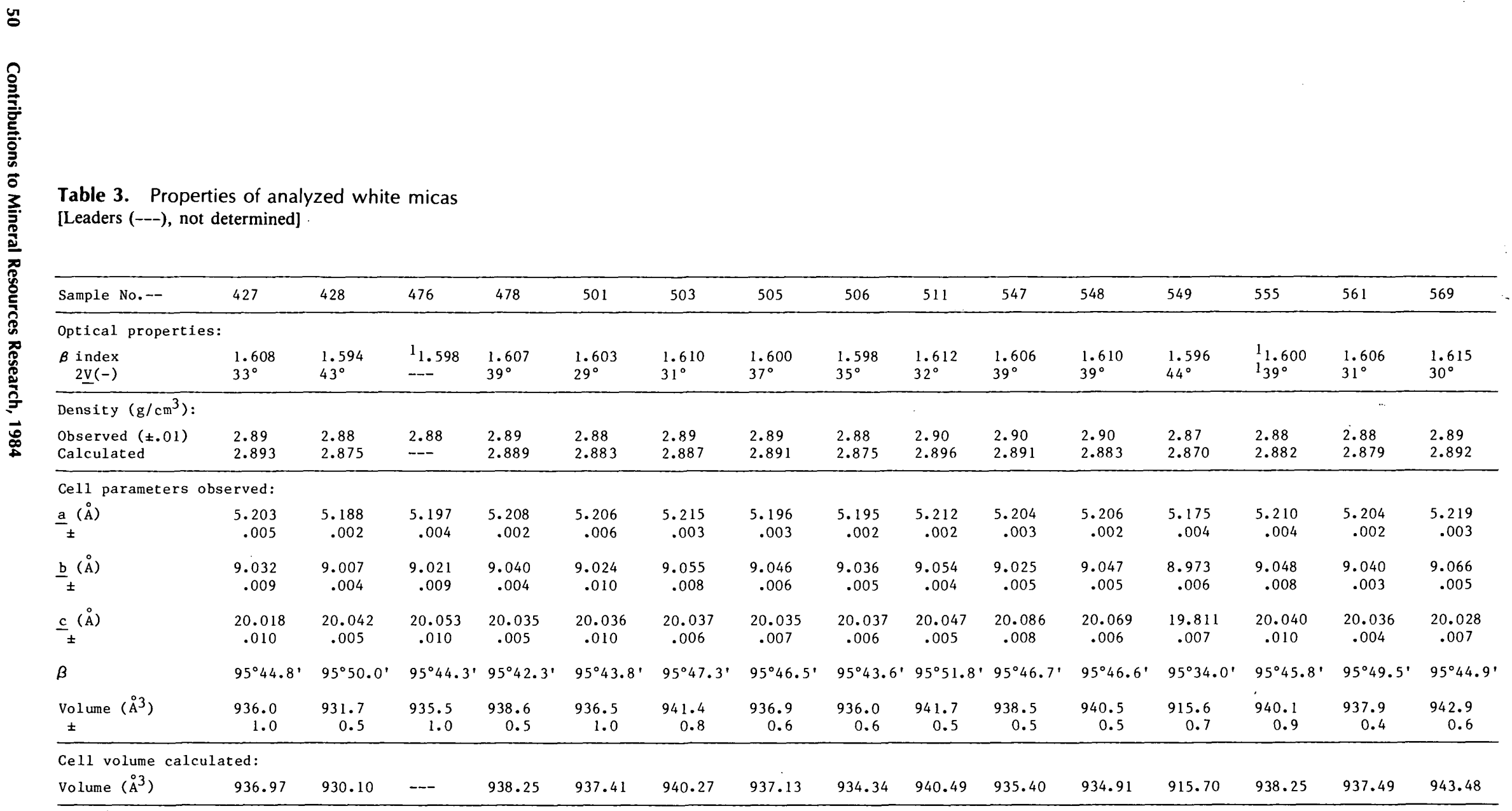

${ }^{1}$ Value uncertain because the mineral is very finely crystalline. 
Table 4. Analytical data for biotites recovered from late Precambrian and Early Cambrian metasedimentary rocks

[Chemical analyses by E.L. Munson Brandt. Quantitative Ba, Rb, and $\mathrm{Sr}$ analyses by W.P. Doering. Semiquantitative spectrographic analyses by L.A. Bradley. Leaders (---), not determined]

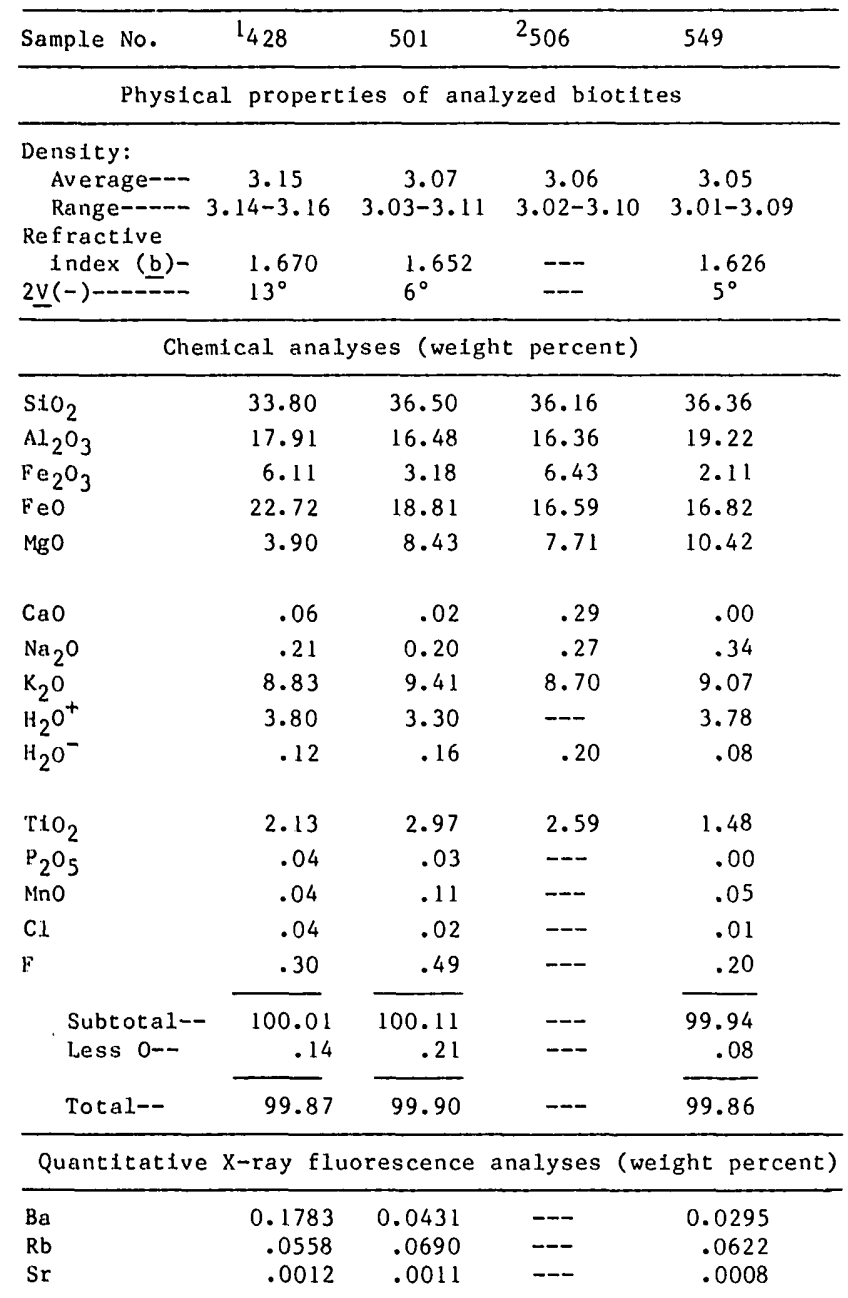

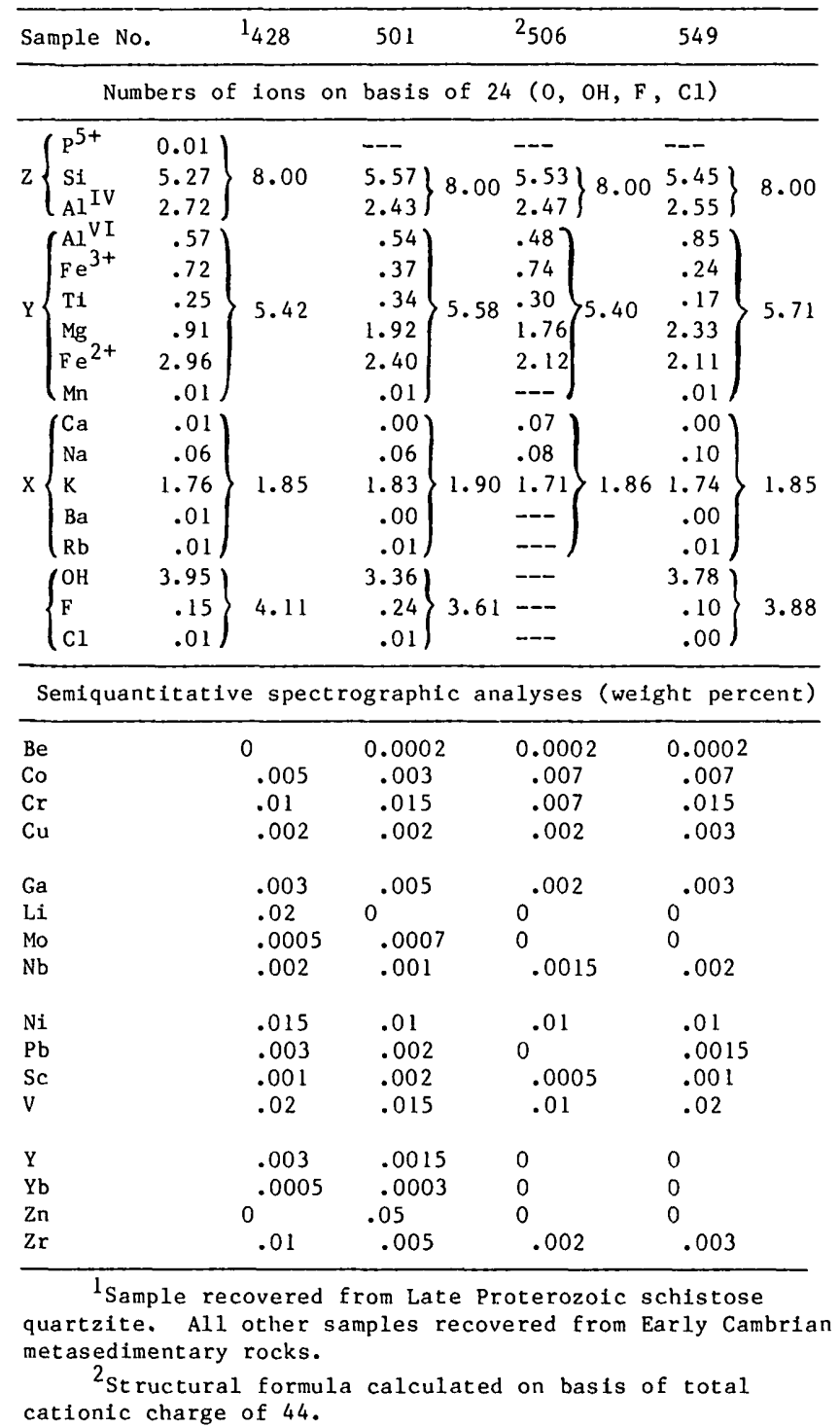

Inasmuch as most of the sample sites are spatially related to regional thrust faults, it is likely that the original $\delta \mathrm{D}$ values of many of the sedimentary rocks were lowered through isotopic exchange with meteoric waters circulating along the fault plane. Meteoric waters are the only abundant natural materials that are depleted in deuterium. However, meteoric waters are also depleted in ${ }^{18} \mathrm{O}$, and the $\delta^{18} \mathrm{O}$ values of most of our micas (table 5, fig. 3) are fairly "normal." It is generally easier to change $\delta \mathrm{D}$ than $\delta^{18} \mathrm{O}$ in a system because of the oxygenbuffering capacity of rocks. Thus, the stable isotope results in table 5 imply rather low water:rock ratios during the isotopic exchange (Taylor, 1977).

\section{CONCLUSIONS}

We still do not understand the timing and conditions of the metamorphic events that have affected the lower plate metaclastic rocks of eastern White Pine County, Nev., despite the many age, chemical, and stableisotope data that have been assembled for these rocks and their constituent micas. Nonetheless, these data may help to direct and place in perspective future studies of these rocks. Such future studies might include: (1) ${ }^{40} \mathrm{Ar} /{ }^{39} \mathrm{Ar}$ dating of selected micas from lower plate metaclastic rocks of eastern White Pine County; (2) additional U$\mathrm{Th}-\mathrm{Pb}$ work on the metamorphic monazite that appears 
to be widespread in the lower plate metaclastic rocks; (3) additional work such as the intensive study of metamorphic and structural features of the Hampton Creek area of the northern Snake Range (Rowles, 1982); and (4) fluid-inclusion work on the recrystallized quartz in samples such as 503 and 561 (fig. 2) to provide evidence bearing on pressures and temperatures of metamorphism.

Table 5. Stable-isotope data and K-Ar ages for micas recovered from late Precambrian and Early Cambrian metasedimentary rocks

$\left[\delta^{18} \mathrm{O}\right.$ and $\delta \mathrm{D}$ determinations by J.D. Gleason; leaders (---), not determined]

\begin{tabular}{|c|c|c|c|c|c|}
\hline $\begin{array}{l}\text { Sample } \\
\text { No. }\end{array}$ & $\begin{array}{l}\text { Rock type } \\
\text { (symbol) }\end{array}$ & Mineral & $\begin{array}{c}\mathrm{K}-\mathrm{Ar} \text { age } \mathrm{e}^{2} \\
\mathrm{Ma}+2 \mathrm{O}\end{array}$ & $\begin{array}{l}\delta^{18} 0, \text { permi1 } \\
\text { (SMOW) }\end{array}$ & $\begin{array}{c}\delta D, \text { perm } 11 \\
(\text { SMOW })\end{array}$ \\
\hline 427 & $p \in$ & $\begin{array}{l}\text { White } \\
\text { mica. }\end{array}$ & $63.6 \pm 2.4$ & -- & --- \\
\hline 428 & $p \in$ & Biotite & $45.8+1.9$ & +3.2 & -182.3 \\
\hline 428 & $p \epsilon$ & $\begin{array}{l}\text { White } \\
\text { mica. }\end{array}$ & $61.7 \pm 2.3$ & +10.8 & -118.0 \\
\hline 476 & $p \in s t r$ & -- do--- & $105+4$ & --- & --- \\
\hline 478 & $p \in \in \mathrm{pm}$ & --do--- & $87 . \overline{4} \pm 2.2$ & +8.0 & -150.5 \\
\hline 501 & $6 p$ & B1otite & $43.3 \pm 1.6$ & +7.6 & -109.3 \\
\hline 501 & $\epsilon p$ & $\begin{array}{l}\text { White } \\
\text { mica. }\end{array}$ & $51.1 \pm 1.4$ & +10.3 & -58.9 \\
\hline 503 & $p \in \in p m$ & -- do--- & $57.1 \pm 1.7$ & +8.8 & -98.6 \\
\hline 505 & $p \in \in p m$ & -- do--- & $54.1 \pm 1.7$ & --- & --- \\
\hline 506 & $p \in € p m$ & -- do--- & $55.2 \pm 1.5$ & +8.8 & -101.9 \\
\hline 511 & $p \in \in \mathrm{pm}$ & Blotite & --- & +4.5 & -124.9 \\
\hline 511 & $p \in \in p m$ & $\begin{array}{l}\text { White } \\
\text { mica. }\end{array}$ & $72.5 \pm 2.0$ & +8.3 & -62.5 \\
\hline 547 & $\mathrm{p} \in \in \mathrm{pm}$ & -- do--- & $20.8 \pm 0.5$ & +9.3 & -167.4 \\
\hline 548 & $p \in \in p m$ & -- do--- & $22.7 \pm 0.5$ & -- & $\cdots$ \\
\hline 549 & $p \in \in p m$ & Biotite & $47.1 \pm 1.6$ & +7.1 & -77.2 \\
\hline 549 & $p \in \in \mathrm{pm}$ & $\begin{array}{l}\text { White } \\
\text { mica. }\end{array}$ & $30.5 \pm 1.0$ & +10.5 & -51.1 \\
\hline 555 & $p \in \in p m$ & -- do-- & $141+5$ & +10.3 & -80.6 \\
\hline 561 & $p \in \in p m$ & -- do--- & $36.9 \pm 0.8$ & +8.4 & -131.3 \\
\hline 569 & $p \in \in p m$ & -- do-- & $66.9 \pm 1.5$ & +8.6 & -77.4 \\
\hline
\end{tabular}

${ }^{1}$ Samples 427 and 428 are the quartzite and mica schist, respectively, of Misch and Hazzard's (1962, p. 308, 309) A of unit A. pe€m, Precambrian and Cambrian Prospect Mountain Quartzite. Ep, Cambrian Ploche Shale; p€str, Precambrian Strawberry Creek Formation of Misch and Hazzard (1962).

${ }^{2} \mathrm{~K}-\mathrm{Ar}$ ages from Lee, Marvin, and Mehnert (1980).

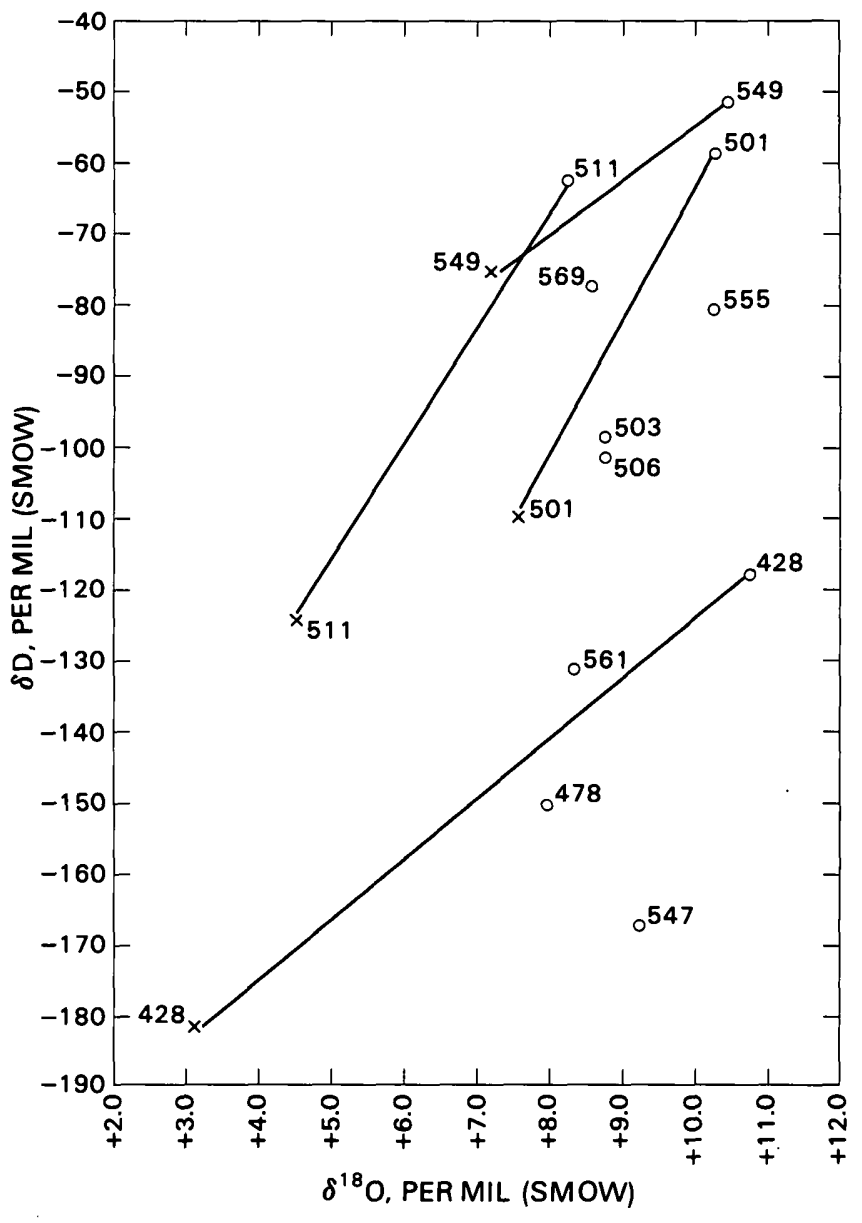

Figure 3. Plot of $\delta^{18} \mathrm{O}$ versus $\delta \mathrm{D}$ values for analyzed micas from metaclastic rocks of eastern White Pine County, Nevada. The large range of generally below "normal" $\delta \mathrm{D}$ values of these micas together with their fairly "normal" $\delta^{18} \mathrm{O}$ values implies rather low water:rock ratios during isotopic exchange (Taylor, 1977). Slopes of lines connecting coexisting white micas (circles) and biotites $(x)$ are similar to slopes of such lines based on data of Frey and others (1976, p. 173). 


\section{REFERENCES CITED}

Butler, B.C.M., 1967, Chemical study of minerals from the Moine schists of the Ardnamurchan area, Argyllshire, Scotland: Journal of Petrology, v. 8, p. 233-267.

Dodge, F.C.W., Smith, V.C., and Mays, R.E., 1969, Biotites from granitic rocks of the central Sierra Nevada batholith, California: Journal of Petrology, v. 10, p. 250-271.

Ernst, W.G., 1963, Significance of phengitic micas from lowgrade schists: American Mineralogist, v. 48, p. 1357-1373.

Foster, M.D., 1956, Correlation of dioctahedral potassium micas on the basis of their charge relations: U.S. Geological Survey Bulletin 1036-D, p. 57-67.

Foster, M.D., Bryant, B., and Hathaway, J., 1960, Iron-rich muscovitic mica from the Grandfather Mountain area, North Carolina: American Mineralogist, v. 45, p. 839-851.

Frey, M., Hunziker, J.C., O’Neil, J.R., and Schwander, H.W., 1976, Equilibrium-disequilibrium relations in the Monte Rosa granite, western Alps: Contributions to Mineralogy and Petrology, v. 55, p. 147-179.

Friedman, Irving, 1953, Deuterium content of natural waters and other substances: Geochimica et Cosmochimica Acta, v. 4 , p. $89-103$.

Friedman, Irving, and O'Neil, J.R., 1977, Compilation of stable isotope fractionation factors of geochemical interest, Chapter KK in Fleischer, Michael, ed., Data of geochemistry (6th edition): U.S. Geological Survey Professional Paper 440-KK, 12 p.

Friedman, Irving, Redfield, A.C., Schoen, B., and Harris, I., 1964, The variation of the deuterium content of natural waters in the hydrologic cycle: Reviews of Geophysics, v. 2, p. 177-224.

Jackson, E.D., Stevens, R.E., and Bowen, R.W., 1967, A computer-based procedure for deriving mineral formulas from mineral analyses, in Geological Survey research 1967: U.S. Geological Survey Professional Paper 575-C, p. C23-C31.

Lee, D.E., and Doering, W.P., 1974, Barium in hybrid granitoid rocks of the southern Snake Range, Nevada: U.S. Geological Survey Journal of Research, v. 2, no. 6, p. 671-675.

1980 , Rubidium and strontium in hybrid granitoid rocks, southern Snake Range, Nevada: U.S. Geological Survey Professional Paper 1158-A, p. 1-7.

Lee, D.E., Marvin, R.F., and Mehnert, H.H., 1980, A radiometric age study of Mesozoic-Cenozoic metamorphism in eastern White Pine County, Nevada, and nearby Utah: U.S. Geological Survey Professional Paper 1158-C, p. 17-28.
Lee, D.E., Marvin, R.F., Stern, T.W., and Peterman, Z.E., 1970, Modification of potassium-argon ages by Tertiary thrusting in the Snake Range, White Pine County, Nevada, in Geological Survey research 1970: U.S. Geological Survey Professional Paper 700-D, p. D92-D102.

Lee, D.E., Stern, T.W., and Marvin, R.F., 1981, Uraniumthorium-lead isotopic ages of metamorphic monazite from the northern Snake Range, Nevada: ISOCHRON/WEST, no. 31, p. 23.

Lee, D.E., and Van Loenen, R.E., 1970, Biotites from hybrid granitoid rocks of the southern Snake Range, Nevada, in Geological Survey research 1970: U.S. Geological Survey Professional Paper 700-D, p. D196-D206.

Lee, D.E., Van Loenen, R.E., Brandt, E.L.M., and Doering, W.P., 1980, Composition of calcium-poor quartzites of late Precambrian and Early Cambrian age from eastern White Pine County, Nevada: U.S. Geological Survey Professional Paper 1158-B, p. 9-16.

Mather, J.D., 1970, The biotite isograd and the lower greenschist facies in the Dalradian rocks of Scotland: Journal of Petrology, v. 11, p. 253-275.

Misch, Peter, and Hazzard, J.C., 1962, Stratigraphy and metamorphism of late Precambrian rocks in central northeastern Nevada and adjacent Utah: American Association of Petroleum Geologists Bulletin, v. 46, p. 289-343.

Müller, G., 1966, Der Einfluss verschiedener Substitutionen auf die Gitterkonstanten von koexistierenden Biotiten und Muskowiten: Contributions to Mineralogy and Petrology, v. 13, p. 59-74.

Peck, L.C., 1964, Systematic analysis of silicates: U.S. Geological Survey Bulletin 1170, $89 \mathrm{p}$.

Rowles, L.D., 1982, Deformational history of the Hampton Creek Canyon area, northern Snake Range, Nevada: Stanford, Calif., Stanford University M.S. thesis, 80 p.

Suzuoka, T., and Epstein, S., 1976, Hydrogen isotope fractionation between $\mathrm{OH}$-bearing minerals and water: Geochimica et Cosmochimica Acta, v. 40, no. 10, p. 1229-1240.

Taylor, H.P., Jr., 1977, Water/rock interactions and the origin of $\mathrm{H}_{2} \mathrm{O}$ in granitic batholiths: Journal of the Geological Society of London, v. 133, p. 509-558.

Velde, B., 1965, Phengitic micas-Synthesis, stability, and natural occurrence: American Journal of Science, v. 263, p. 886-913.

Wones, D.R., 1963, Physical properties of synthetic biotites on the join phlogopite-annite: American Mineralogist, v. 48, nos. 11-12, p. 1300-1321. 
Chapter E
Metallogeny of Archean and Proterozoic Terranes in the Great Lakes Region-A Brief Overview

By PAUL K. SIMS

A description of major mineral deposits of known or potential future importance

U.S. GEOLOGICAL SURVEY BULLETIN 1694

CONTRIBUTIONS TO MINERAL RESOURCES RESEARCH, 1984 


\section{CONTENTS}

Abstract $\mathbf{5 7}$

Introduction 57

General geology 57

Archean gneiss terrane $\mathbf{5 8}$

Archean greenstone-granite terrane $\mathbf{5 8}$

Early Proterozoic epicratonic sequence 59

Early Proterozoic magmatic terrane $\mathbf{6 0}$

Ladysmith-Pembine belt $\mathbf{6 1}$

Chippewa-Wausau belt 63

Marshfield-Stevens Point belt 64

Middle Proterozoic Midcontinent rift system 64

Summary of tectonic evolution $\mathbf{6 4}$

Metallogeny 65

Deposits in island-arc crustal terranes $\mathbf{6 6}$

Massive sulfide deposits $\mathbf{6 6}$

Algoma-type iron-formations 67

Nickel-copper deposits $\mathbf{6 8}$

Gold deposits $\mathbf{6 8}$

Deposits in continental crustal terranes 68

Superior-type iron-formations 68

Carbonate-hosted copper deposits 69

Conglomerate-hosted uranium deposits 69

Volcanic- and shale-hosted copper deposits 69

Gabbro-hosted copper-nickel deposits $\mathbf{7 0}$

Algoma-type iron-formation $\mathbf{7 0}$

Summary of tectonic evolution and mineralization $\mathbf{7 0}$

References cited $\mathbf{7 1}$

\section{FIGURES}

1. Map of southern margin of Canadian Shield showing Midcontinent rift system and edge of Phanerozoic platform cover $\mathbf{5 8}$

2. Generalized geologic map of major Precambrian tectono-stratigraphic terranes in Lake Superior region $\mathbf{5 9}$

3. Paleogeologic maps of Archean terranes in Great Lakes region $\mathbf{6 0}$

4. Paleogeologic maps of Proterozoic terranes in Great Lakes region 61

5. Generalized geologic map of northern Wisconsin, showing belts of magmatic terrane 62

6. Map of Lake Superior region, showing major known and potential metallic mineral districts in Precambrian rocks 67

TABLES

1. Mineral deposits in island-arc crust, Lake Superior region 66

2. Characteristics of massive sulfide deposits in the Wisconsin magmatic terrane 66

3. Mineral deposits in continental crust, Lake Superior and Lake Huron regions 69 


\title{
Metallogeny of Archean and Proterozoic Terranes in the Great Lakes Region-A Brief Overview
}

\author{
By Paul K. Sims
}

\begin{abstract}
Four major Precambrian tectono-stratigraphic terranes have been delineated in the Great Lakes region of the United States and Canada. Two of these-an Archean greenstonegranite terrane and an Archean gneiss terrane-have a partial epicratonic cover, which is a continental margin sequence of Early Proterozoic miogeoclinal rocks. The third is an Early Proterozoic eugeoclinal oceanic-arc assemblage (Wisconsin magmatic terrane) that mainly lacks an Archean basement, and the fourth is a Middle Proterozoic rift assemblage (Midcontinent rift system). The two Archean terranes were sutured together in Late Archean time, and the Early Proterozoic oceanic-arc assemblage was accreted to the North American continent about 1,850 Ma. The Midcontinent rift system is a major intracontinental rift (about 1,100 Ma) that aborted before significant crustal separation took place.

Major known or potential ore deposits occur in all terranes except the Archean gneiss. These deposits can be grouped into two classes according to the tectonic environment in which they formed: island-arc crust and continental crust.

Of the four types of major mineral deposits in island-arc crust, only one is common to both the Early Proterozoic Wisconsin magmatic terrane and the Archean greenstonegranite terrane: volcanic-hosted $\mathrm{Cu}-\mathrm{Zn}$ type massive sulfide deposits. The massive sulfide deposits are in calc-alkaline and tholeiitic volcanic rocks having island-arc chemical affinities. The other deposits in island-arc crust-Algoma-type ironformations, ultramafic- and gabbro-hosted $\mathrm{Cu}-\mathrm{Ni}$ deposits, and stratabound- and intrusion-hosted Au deposits-are virtually restricted to Archean rocks and, except for the ironformations, occur mainly in Canada.

With respect to deposit types in continental crust, the Early Proterozoic epicratonic rocks of the Lake Superior region contain the vast Superior-type iron-formations and apparently subeconomic carbonate-hosted copper deposits. In the Lake Huron area of Canada, major conglomerate-hosted uranium deposits occur in the Huronian Supergroup, a continentalmargin accumulation like the miogeoclinal sequence in the Lake Superior region. The Middle Proterozoic rocks of the Midcontinent rift system have deposits containing chalcophile elements, which ultimately were derived from magmas ascending from the mantle. The principal developed deposits are the famous volcanic- and sedimentary-hosted copper deposits on the Keweenaw Peninsula. A major resource for the future
\end{abstract}

is the large, marginal-grade gabbro-hosted $\mathrm{Cu}-\mathrm{Ni}$ deposits of the Duluth Complex, northern Minnesota.

\section{INTRODUCTION}

The Great Lakes region is well known for its diverse Precambrian geology and for its vast iron, copper, and uranium resources. Not as well known is the presence of important-and as yet untapped-base-metal deposits, such as the gabbro-hosted copper-nickel sulfide deposits in the Duluth Complex, northern Minnesota, of Middle Proterozoic age, and the volcanic-hosted massive sulfide deposits in northern Wisconsin, of Early Proterozoic age.

Knowledge of the geology of the region has advanced considerably during the past few years, and it is now possible to relate the major mineral deposits to specific tectono-stratigraphic terranes and, to a certain extent, to postulated plate tectonic regimes. A terrane, as defined in the region, has a unique stratigraphy, structure, metamorphism, plutonism, and age, and at least in part is fault-bounded.

The purpose of this report is to discuss, in brief, the metallogeny of each of the terranes that has been delineated in the Great Lakes region, and to relate the mineral resources to inferred plate tectonic models. Only major mineral deposits of known or potential future importance are discussed, and emphasis is given to deposits in the United States. A few deposits known to occur in adjacent Ontario, Canada, but not in the United States are mentioned because of the possibility that such deposits could exist in this country. This report is a revision of an earlier one (Sims, 1976), as well as an elaboration of an oral presentation to a Society of Economic Geologists symposium at the 113th annual meeting of SME-AIME in Los Angeles, Calif., February 1984.

\section{GENERAL GEOLOGY}

The Great Lakes region is on the southern margin of the Superior province of the Canadian Shield (fig. 1). 


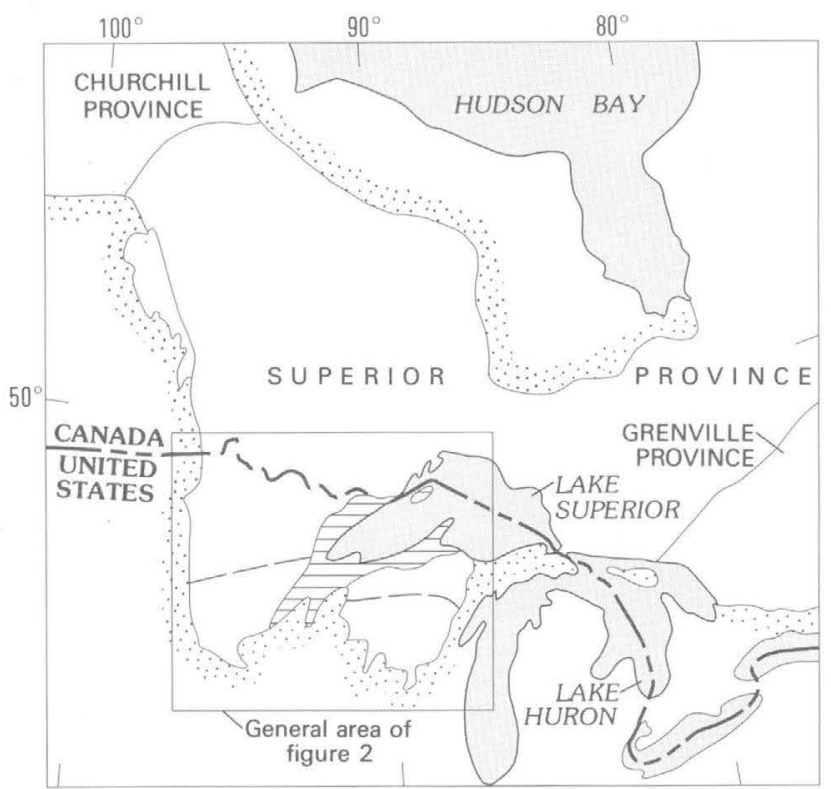

Figure 1. Map of southern margin of Canadian Shield, showing location of Lake Superior and adjacent Lake Huron regions. Horizontal line pattern, Midcontinent rift system; dashed line, southern edge of Superior province; dot pattern, edge of Phanerozoic platform cover. Modified from King and Edmonston (1972).

The Precambrian rocks in the region are overlapped by platform strata of Paleozoic and Mesozoic age on the west, south, and east, and are irregularly covered by Pleistocene glacial deposits.

Four major geologic terranes have been delineated in the Lake Superior region (fig. 2): (1) an Archean gneiss terrane; (2) an Archean greenstone-granite terrane; (3) an Early Proterozoic magmatic terrane (a eugeoclinal volcanic-plutonic sequence), most of which apparently lacks an Archean basement; and (4) a Middle Proterozoic intracontinental rift assemblage (Midcontinent rift system). An Early Proterozoic epicratonic, dominantly miogeoclinal sequence forms a partial cover overlapping the composite Archean basement.

It is useful to discuss the sequential development of the individual terranes and their inferred tectonic environments by means of a series of simplified regional paleogeologic maps.

\section{Archean Gneiss Terrane}

The oldest crustal segment in the region is the Archean gneiss terrane (Morey and Sims, 1976). The inferred position of this terrane during the Archean, as reconstructed prior to Keweenawan rifting and based on its present-day relative position, is shown in figure $3 \mathrm{~A}$. Rocks of this terrane are exposed in southern Minnesota, principally in the Minnesota River Valley, and in the cores of mantled gneiss domes and uplifts in east-central Minnesota and northern Michigan; they are inferred to extend eastward into the southern part of the Lake Huron region (Sims and others, 1981). The westward extension into South Dakota and the southern limit during Archean time are uncertain. The terrane is composed mainly of varied migmatitic gneisses and amphibolite, of amphibolite- and granulite-metamorphic facies, and includes metapelites and granitic plutons (Grant, 1972). Migmatitic gneisses in the Minnesota River Valley record a long history of rock-forming events. They have $\mathrm{U}-\mathrm{Pb}$ zircon and $\mathrm{Rb}-\mathrm{Sr}$ isochron ages of about 3,500 Ma (Goldich and Wooden, 1980), they were modified by addition of a granitic neosome about 3,000 $\mathrm{Ma}$, and they were metamorphosed at 3,050 and 2,600 $\mathrm{Ma}$, followed by a low-grade thermal event at 1,800 Ma. Granitic bodies of batholithic dimensions were intruded at about 2,600 Ma. Gneisses of comparable age and complexity are exposed in the Watersmeet dome in northern Michigan. A tonalitic augen gneiss and associated biotite gneiss have U-Pb zircon ages of $\approx 3,560 \mathrm{Ma}$, and a younger succession of interlayered amphibolite and biotite gneiss has a zircon age of $\approx 2,640 \mathrm{Ma}$ (Sims and others, 1984). These rock types are intruded by a $\approx 2,600$-m.y.-old leucogranite. Intense deformation and metamorphism during the Early Proterozoic orogenic event reset whole-rock and mineral Rb-Sr systems in the interval 1,800-1,750 Ma.

\section{Archean Greenstone-Granite Terrane}

Voluminous mafic to felsic volcanic rocks and related volcanogenic graywacke accumulated adjacent to the north side (present-day relative position) of the gneiss terrane (fig. $3 B)$ in Late Archean time $(\approx 2,700 \mathrm{Ma})$. They were intruded by abundant tonalite-granodiorite and granite bodies, many of batholithic dimensions. The depositional overlap of the Late Archean volcanic rocks onto the adjacent gneiss terrane, to the south, and the tectonism and plutonic stitching in the boundary zone (Great Lakes tectonic zone; Sims and others, 1980) sutured the greenstone-granite terrane to the older gneiss terrane. The greenstone-granite terrane (Superior province of Canadian usage) represents the single greatest addition of volcanic-plutonic rocks to the North American crust in Precambrian time. The mafic volcanic rocks are dominantly tholeiitic basalt; the lesser felsic volcanic rocks have both tholeiitic and calc-alkaline affinities (Campbell and others, 1982; Schulz, 1980). The tectonic environment in which the greenstone-granite complexes were formed is still debated, but the rocks have oceanic and island-arc compositional affinities. The granitoid rocks are mainly calc-alkaline, but relatively late tectonic and post-tectonic rocks typically are alkaline. The 


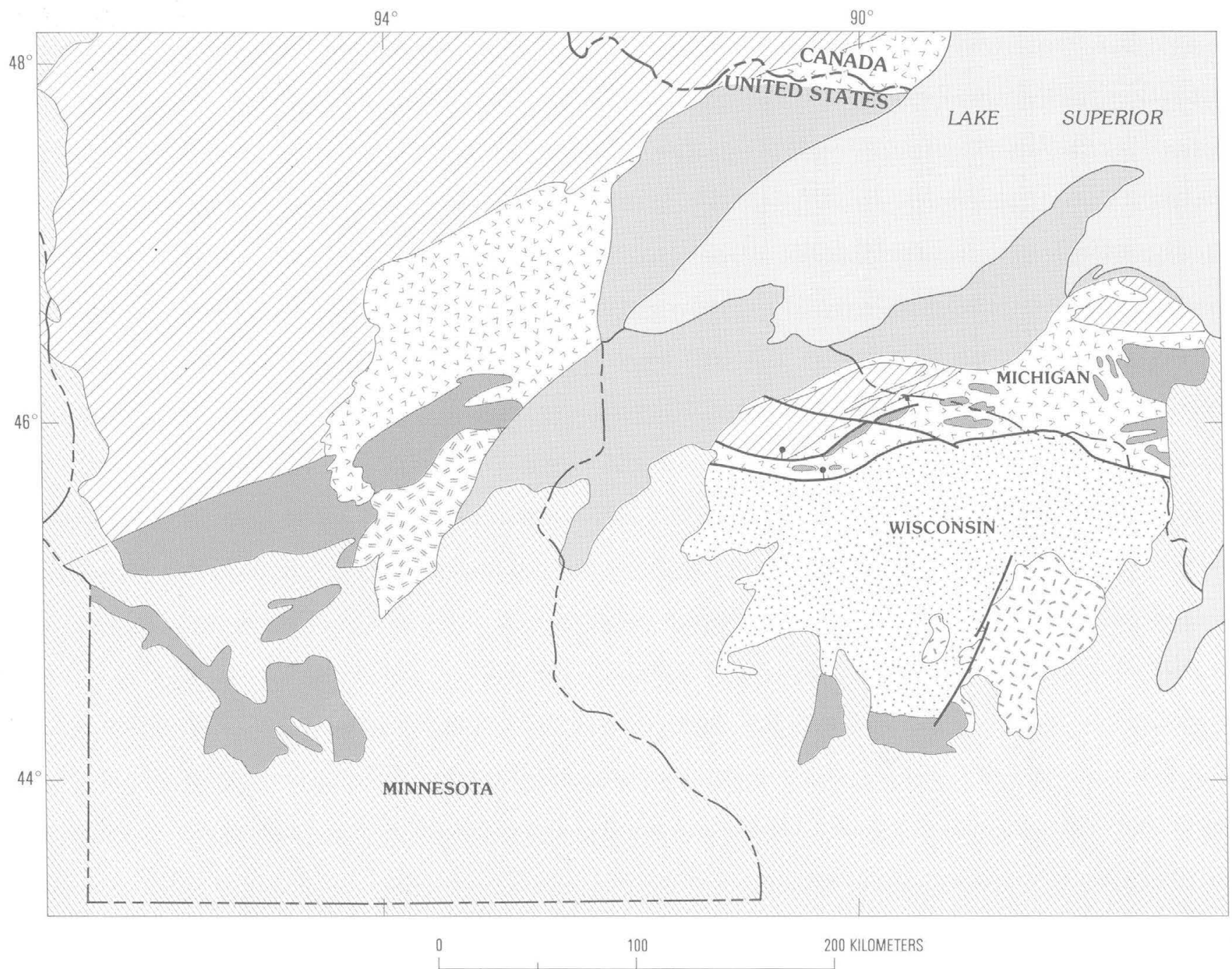

EXPLANATION
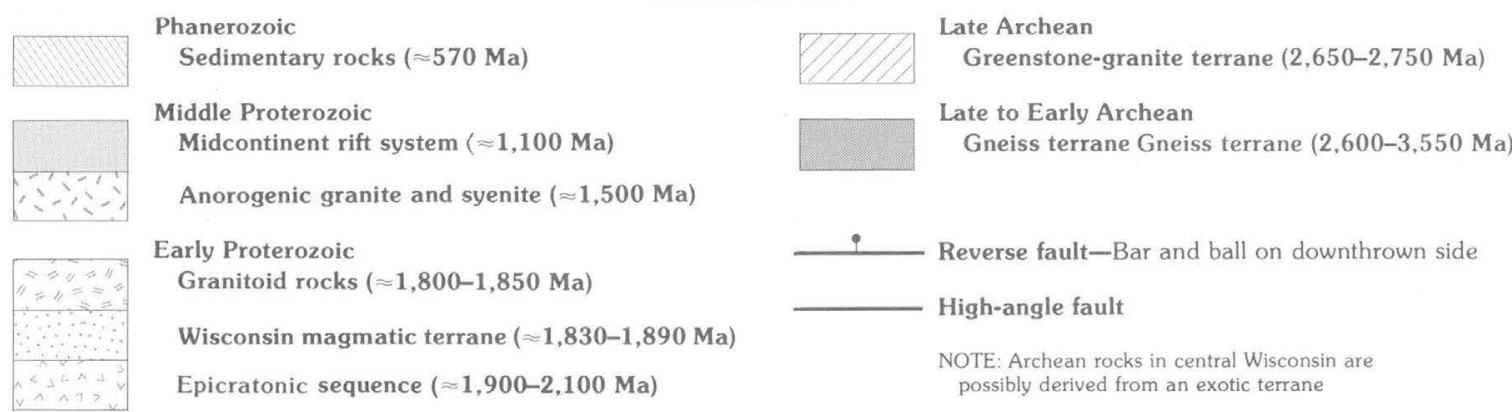

Figure 2. Generalized geologic map of Lake Superior region, showing major Precambrian tectono-stratigraphic terranes. Modified from Morey and others (1982).

granitoid rocks have initial ${ }^{87} \mathrm{Sr} /{ }^{86} \mathrm{Sr}$ of less than 0.701 (Sims and Peterman, 1981) and appear to have been derived either by fractional melting of basic rocks or by partial melting of graywacke having a short crustal residence time (Arth and Hanson, 1975). This segment of the crust stabilized by the end of Archean time (2,500 Ma).

\section{Early Proterozoic Epicratonic Sequence}

Following stabilization of the crust, two apparently separate asymmetrical sequences of sediments accumulated in the Great Lakes region along the southern margin of the Archean craton (fig. $4 A$ ): an older sequence 

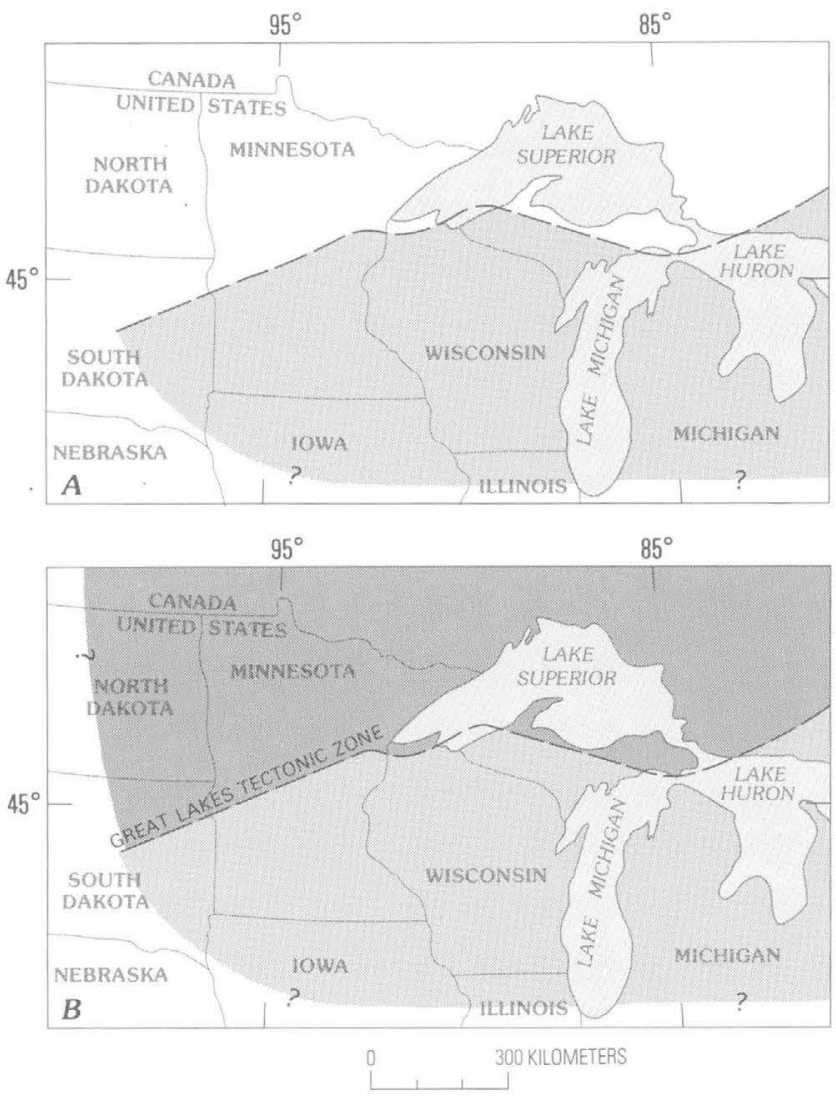

EXPLANATION

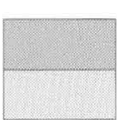

Archean

Greenstone-granite terrane

Gneiss terrane

Known or inferred terrane boundary

Figure 3. Paleogeologic maps of Archean terranes in the Great Lakes region (present coordinates). A, Archean gneiss $(2,600-3,550 \mathrm{Ma}) ; B$, Archean continent $(\approx 2,500 \mathrm{Ma})$. Extent of terranes queried where uncertain.

in the Lake Huron area, the Huronian Supergroup of Canada, and a somewhat younger sequence in the Lake Superior region, the Marquette Range Supergroup and its equivalents in Minnesota (Sims and others, 1981; Morey, 1983; Cannon and Gair, 1970). Volcanic rocks at the base of the Huronian have U-Pb zircon ages of about 2,500 Ma (K.D. Card, oral commun., 1984); sedimentation terminated by about $2.1 \mathrm{Ga}$ (Sims and others, 1981). The time of deposition of the Marquette Range Supergroup is poorly known, but it probably spanned the interval 2,100-1,900 Ma. Depositional patterns of rocks in the Marquette Range Supergroup, as well as in the Huronian Supergroup, reflect contrasting tectonic conditions in the northern and southern segments of the depositional basin, whose axis was approximately over and parallel to the Great Lakes tectonic zone (fig. $4 A)$. A relatively thin $(<2 \mathrm{~km})$ succession of sedimentary rocks, represented especially by the Animikie Group in northern Minnesota (Morey, 1973), was deposited over relatively nonstretched (stable) Archean greenstonegranite complexes on the north, whereas a much thicker $(\approx 6 \mathrm{~km})$ succession of interlayered sedimentary and volcanic rocks accumulated on stretched Archean gneiss basement on the south. Sedimentation began with deposition of quartz-rich and carbonate rocks and continued with precipitation of major iron-formations. South of the Great Lakes tectonic zone, in the area of stretched crust, these miogeoclinal rocks were deposited in rather narrow, fault-bounded basins only tens of kilometers long and on intervening platforms (Larue and Sloss, 1980); north of the tectonic zone sedimentation occurred within a single (Animikie) basin several hundred square kilometers in area, which composed a southward-facing shelf. Later, the shelf foundered into deeper water, and a thick, southward-facing, flysch-like clastic wedge was deposited by southward-flowing turbidity currents. In Michigan, abundant volcanic rocks were intermittently extruded through stretched crust during accumulation of the deeper water sediments. Chemically, the volcanic rocks in northern Michigan are largely bimodal, with abundant tholeiitic basalt and minor high $-\mathrm{K}_{2} \mathrm{O}$ rhyolite. The basalts show strong iron enrichment and high $\mathrm{TiO}_{2}$ and incompatible-element contents (Fox, 1983); they are compositionally similar to continental rift basalts, such as those of the Keweenawan in Minnesota (Green, 1983).

There is now a general consensus that the Early Proterozoic rocks in the Lake Superior region accumulated on a south-facing, rifted, passive continental (Atlantic-type) margin undergoing north-south extension (Sims and Peterman, 1984), as proposed earlier by Cambray (1978) and Larue and Sloss (1980) (fig. 4A).

\section{Early Proterozoic Magmatic Terrane}

The relation of the Early Proterozoic sequence in Wisconsin, dominated by volcanic and plutonic rocks, to the epicratonic sequence (Marquette Range Supergroup) in Michigan has been uncertain, because of poor exposures, sparse geologic mapping, and lack of chemical data on the volcanic and plutonic rocks of Wisconsin. A recently completed regional geologic map (Morey and others, 1982) and new chemical data (Greenberg and Brown, 1983; Schulz, 1984), however, support an oceanic-arc complex-origin for the magmatic terrane and the subsequent accretion to the continent on the north during the Penokean orogeny $(\approx 1,850 \mathrm{Ma})$ (fig. $4 B)$. This terrane is informally called the Wisconsin magmatic terrane in this report.

The Wisconsin magmatic terrane consists of abundant mafic to felsic volcanic rocks and granitoid rocks ranging from tonalite to granite, and lesser, intercalated sedimentary rocks. An Archean basement is present in 

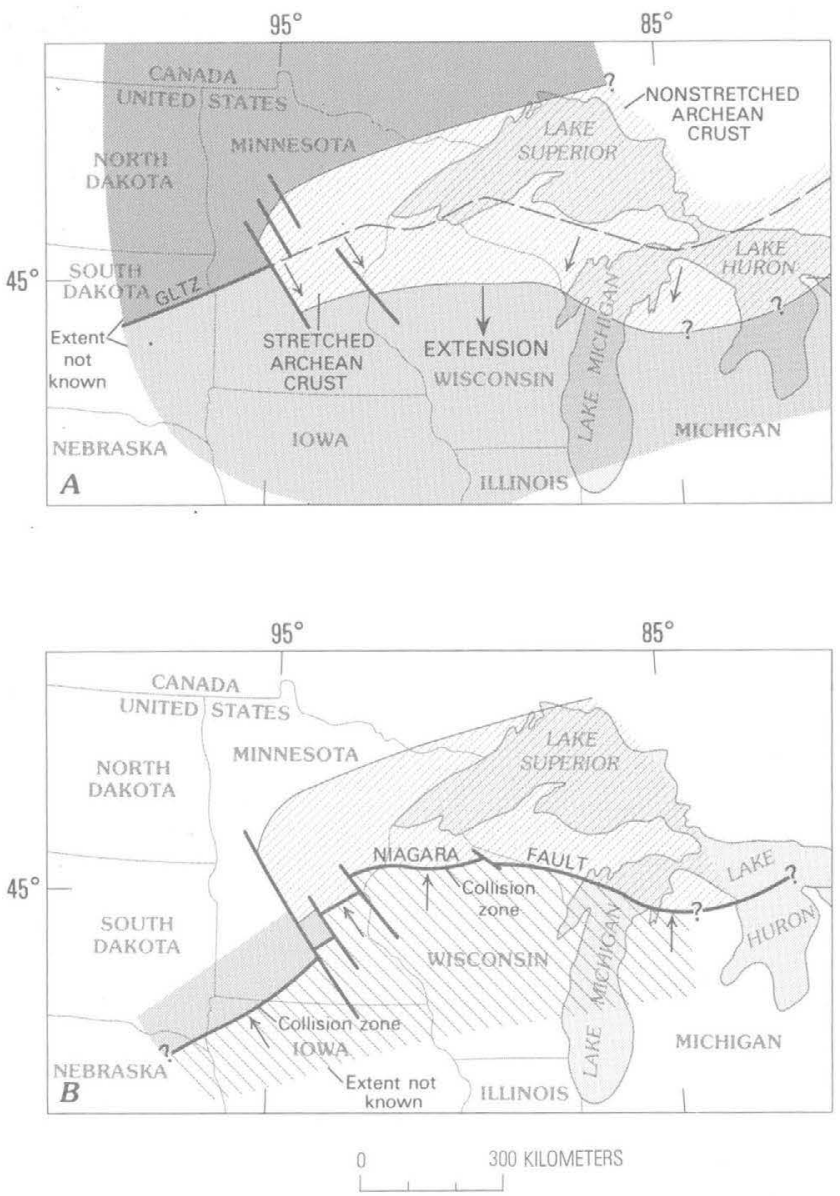

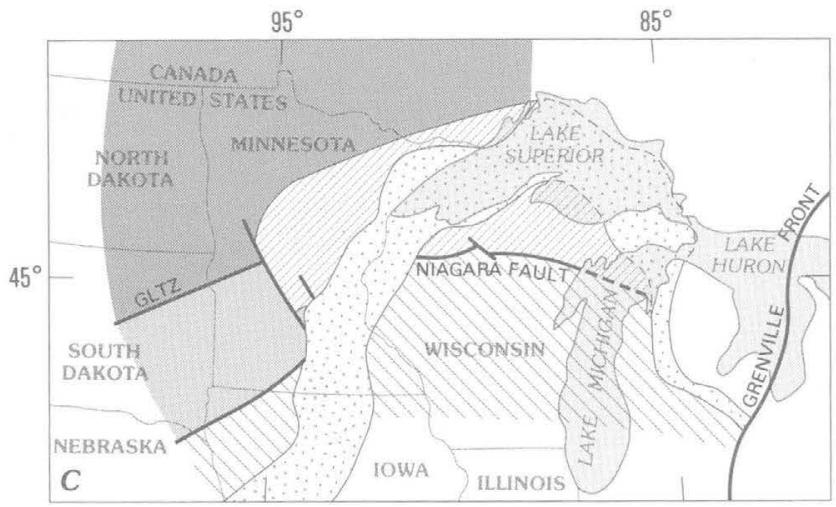

EXPLANATION

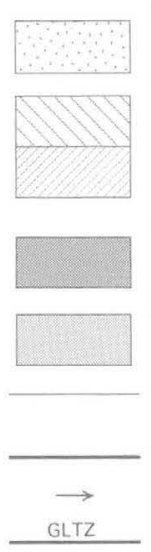

Middle Proterozoic

Midcontinent rift system

Early Proterozoic

Wisconsin magmatic terrane

Marquette Range Supergroup and correlative rock; Archean basement exposed locally

Late Archean

Greenstone-granite terrane

Late to Early Archean

Gneiss terrane

Contact-Approximately located; dashed where now covered by water; queried where uncertain

Fault-Dashed where approximate; queried where uncertain Direction of tectonic transport

GLTZ

Great Lakes tectonic zone; boundary between Archean terranes; extension beneath Marquette Range Supergroup shown as dashed line

Figure 4. Paleogeologic maps of Proterozoic terranes in the Great Lakes region (present coordinates). A, Early Proterozoic epicratonic sequences $(1,900-2,500 \mathrm{Ma})$ deposited on a rifted continental margin; $B$, Penokean orogeny $(\approx 1,850 \mathrm{Ma})$ resulting from collision between Wisconsin magmatic terrane and continental margin; C, Midcontinent rift system ( $\approx 1,100-1,225 \mathrm{Ma})$.

central Wisconsin (fig. 5). Whether this Archean crustal segment was rifted from the continental margin and later returned or whether it originated elsewhere is not known. The terrane is bounded on the north by the Niagara fault. It appears to extend westward across the Midcontinent rift system into Minnesota and northwestern Iowa (Anderson and Black, 1983), as shown diagrammatically in figure $4 B$.

The Wisconsin magmatic terrane is tentatively divided into three sub-terranes (fig. 5), or belts, each of which has internal characteristics that distinguish it from adjacent terranes. The distinguishing characteristics are rock types, stratigraphy, structure, metamorphism, plutonism and, to some extent, age.

\section{Ladysmith-Pembine Belt}

The Ladysmith-Pembine belt, the northernmost sub-terrane in Wisconsin, is arc-shaped, about $80 \mathrm{~km}$ wide, and more than $300 \mathrm{~km}$ long. Geophysical data indicate that the belt extends at least another $100 \mathrm{~km}$ southeastward. The belt is composed mainly of (1) metamorphosed basalt-andesite-rhyolite, (2) an apparently continuous basement of Early Proterozoic gneiss having a combined volcanic-plutonic protolith, and (3) intrusive rocks ranging in composition from gabbro to granite. In the best exposed area, in northeastern Wisconsin (Sims and others, 1985), a thick $(\approx 1 \mathrm{~km})$ succession of metamorphosed shallow-water dolomite, quartzite, carbonaceous shale, and calc-silicate rocks underlies the volcanic rocks. Except for the 1,835-m.y.-old Athelstane batholith in northeastern Wisconsin (fig. 5) and a few smaller plutons in northwestern Wisconsin, the granitoid rocks are closely associated with the Early Proterozoic gneiss in the cores of domes, having been intruded mainly along the core-cover contact in the domes. Geologic and geochronologic data from northeastern Wisconsin indicate that the gneiss and overlying volcanic rocks are $\approx 1,865 \mathrm{Ma}$ old; the intrusive rocks range in age from $\approx 1,860$ to $1,835 \mathrm{Ma}$. Younger epizonal granite, dated at $1,760 \mathrm{Ma}$, locally intrudes the older granitoid rocks in the domes. 


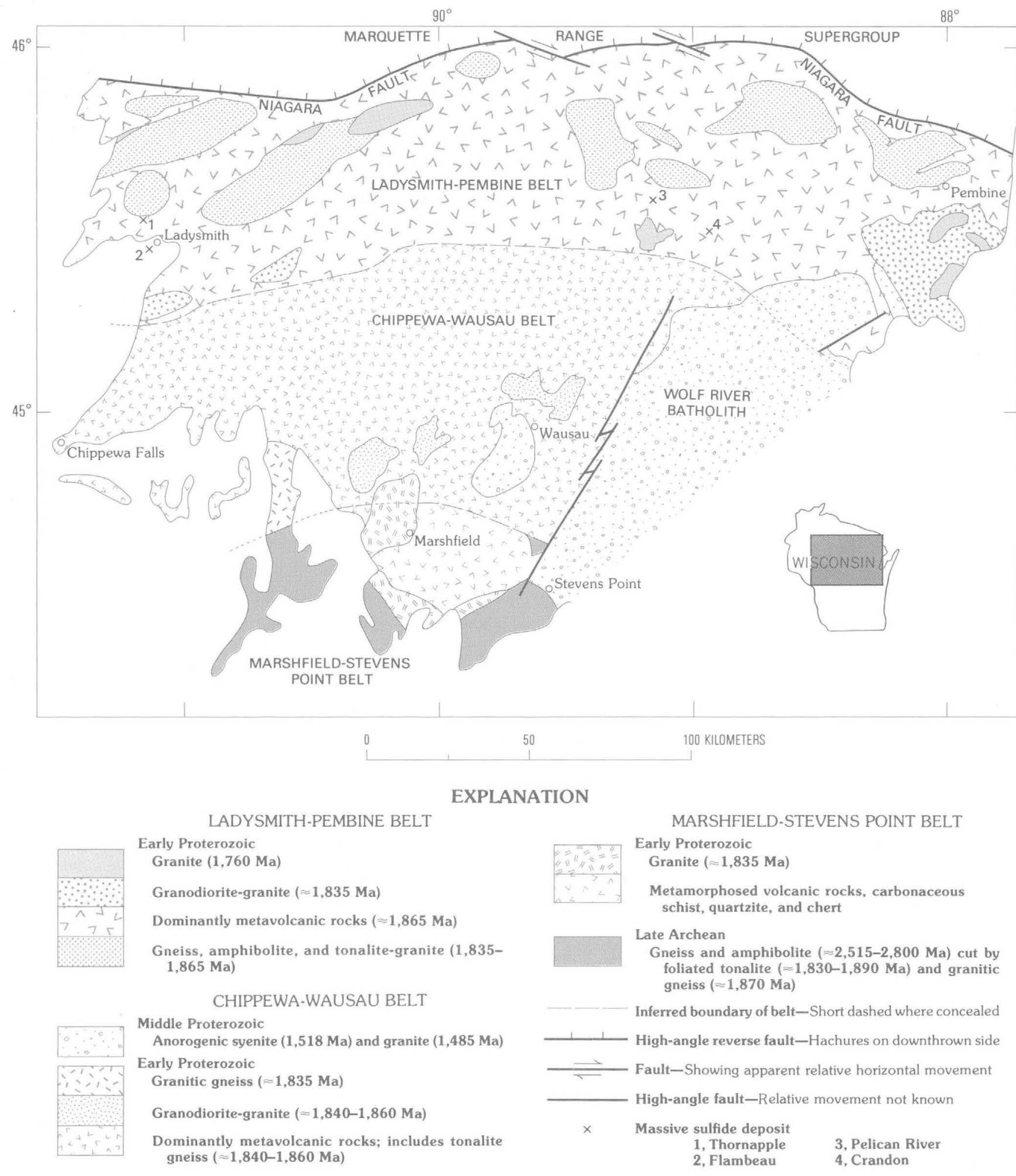

Figure 5. Generalized geologic map of northern Wisconsin, showing three sub-terranes (belts) of magmatic terrane. Modified from Morey and others (1982); age data mainly from W. R. Van Schmus, written commun., 1984. 
The volcanic rocks in the Ladysmith-Pembine belt (Schulz, 1984) are dominantly calc-alkaline and are enriched in LIL (large-ion lithophile) elements $\left([\mathrm{La} / \mathrm{Yb}]_{N}=2.5-9.4\right)$ but are depleted in high-fieldstrength elements ( $\mathrm{Hf}, \mathrm{Zr}, \mathrm{Ta}$, and others). They are similar to volcanic sequences found in recent island-arcs (such as New Hebrides and Japanese arcs). In contrast, basalt (Quinnesec Formation) from the same belt in northeastern Wisconsin is tholeiitic and strongly depleted in LIL elements $\left([\mathrm{La} / \mathrm{Yb}]_{\mathrm{N}}=0.09-0.89\right)$. This basalt is compositionally similar to recent back-arc basin basalts (for example, Lau Basin) and island-arc tholeiites (for example, Scotia arc).

The Early Proterozoic gneiss and volcanic rocks are polydeformed and metamorphosed. The major deformation, regional in scope, produced tight folds whose axial planes form a gentle, arcuate pattern that is subparallel to the trace of the Niagara fault (fig. 5). The folds have steep limbs and steep plunges. This deformation was accompanied by greenschist facies metamorphism and, locally in the western part of the belt, by low-amphibolite facies. At places, younger northeast-trending tight to open folds produced fold-interference domal structures cored by the Early Proterozoic gneisses; these domal structures were further modified by diapirism, which produced mylonite and a steep-stretching lineation in dome boundaries. The gneiss domes have a surrounding annular, thermal metamorphic aureole, which reached middle amphibolite facies (Bayley and others, 1966).

The position of the southern margin of the Ladysmith-Pembine volcanic-plutonic belt is ill defined and is partly based on interpretation of aeromagnetic and gravity data; presumably, this margin is a major fault.

\section{Chippewa-Wausau Belt}

An arcuate belt of volcanic and plutonic rocks to the south of the Ladysmith-Pembine belt (fig. 5) is comparable in width to the northern belt but is truncated on the east by the Wolf River batholith $(\approx 1,500 \mathrm{Ma}$; Van Schmus and others, 1975). The belt differs from the belt on the north in that it consists of two distinct, major volcanic successions of different lithology, metamorphic grade, and structure (LaBerge and Myers, 1984). A possible third, younger volcanic succession is present locally in the Wausau area.

The older volcanic succession consists of interlayered quartzofeldspathic gneiss and schist (felsic volcanic rocks) and amphibolite (mafic volcanic rocks), which are intruded by abundant tonalite-granodioriteprobably entirely subvolcanic intrusions. Intrusion breccias are commonly associated with the intrusions. Chemically, the rocks are tholeiitic and calc-alkaline, having overall island-arc affinity. This succession apparently forms the basement in this volcanic belt. It is metamorphosed mainly to amphibolite facies and is deformed on west- to northwest-trending fold axes; the folds are tight, plunge steeply, and have steep limbs.

The second, younger succession consists of basalt, andesite, and rhyolite, and has large subvolcanic intrusions of quartz monzonite composition and some intercalated conglomerate, graywacke, arkose, and quartzite (LaBerge and Myers, 1983). The conglomerate clasts include granitoid rocks. The rocks are widely distributed and now apparently compose scattered patches in fault contact with the older succession. The rocks are deformed on northeast fold axes that plunge moderately to the northeast or southwest; they have a penetrative schistosity and are mainly metamorphosed to middle or upper greenschist facies. Although regional in scope, the deformation was remarkably inhomogeneous. It was intense in certain northeast-trending ductile deformation zones, such as the Milan shear zone (Sims and Peterman, 1983, fig. 3), where strain indicators show as much as 40 percent shortening (Palmer, 1980), whereas it was relatively mild in other areas. Metamorphism reaches low amphibolite facies in these deformation zones.

The third, youngest succession consists mainly of rhyolite and volcanogenic graywacke that occupies an area of about $12 \mathrm{~km}^{2}$ in the vicinity of Wausau. LaBerge and Myers (1984) described welded tuff, flowbanded rhyolite and rhyolite breccia, lahars, and interbedded sandstone and conglomerate-indicative of probable subaerial accumulation-from the succession; it is possibly an erosional remnant of a rhyolite plateau or caldera complex. The rocks are mildly metamorphosed (low greenschist facies), lack penetrative structures, and are deformed on gently plunging northeast-trending fold axes.

In addition to the subvolcanic intrusive rocks associated with successions one and two in this belt, a quartz monzonite pluton characterized by clotty biotite intrudes the two older successions in an area west of Wausau (Cherokee Granite of LaBerge and Myers, 1983). The most abundant intrusive rocks, however, are pink leucocratic granite bodies that intrude and apparently are coeval with succession three. Judged from the mapping of LaBerge and Myers (1983), the granite occurs as several separate(?) plutons, each of which is a few tens of square kilometers in area. The granite has moderately high $\mathrm{K}_{2} \mathrm{O} / \mathrm{Na}_{2} \mathrm{O}$ as compared with the intrusive rocks in the Ladysmith-Pembine belt.

The southern margin of the belt is a ductile deformation (shear) zone along the Eau Pleine River, south of Wausau; this zone is marked by local mylonite, small bodies of ultramafic rocks, and a prominent northwestto west-trending aeromagnetic anomaly (LaBerge and Myers, 1983). 
Marshfield-Stevens Point Belt

The third, most southerly exposed sub-terrane, the Marshfield-Stevens Point belt (fig. 5), differs from the other two belts in possibly having a continuous Archean gneiss basement; it also has a distinctive deformation style (Maass, 1983) characterized by steeply plunging fold axes and mineral lineations. Maass has recognized two main generations of folds: isoclinal $F_{1}$ folds and tight to very open $F_{3}$ folds, which are coaxial.

Archean gneiss and amphibolite are exposed in the southern and western parts of the terrane, in major river valleys. The gneisses have U-Pb zircon ages of about 2,800 Ma (Van Schmus and Anderson, 1977; Du Bois and Van Schmus, 1978). The Archean gneisses are intruded by abundant, generally small bodies of tonalite, granodiorite, and granite, and all but the granite are deformed by $F_{1}$ and $F_{3}$. A tonalite near Stevens Point has a U-Pb zircon age of $1,892 \pm 9 \mathrm{Ma}$ (W. R. Van Schmus, written commun., 1984). East of Marshfield (fig. 5), the Archean gneiss is overlain by a succession of mafic to felsic volcanic rocks that have numerous interbeds of ferruginous chert, white quartzite, conglomerate, and carbonaceous shale (tuff?). The rocks are middle greenschist facies and are folded into a steeply inclined syncline. Clearly, they are Early Proterozoic in age because they have the same steep penetrative lineation as the dated tonalite. Maass, Medaris, and Van Schmus (1980) have demonstrated that the deformation took place between about 1,880 and 1,825 Ma. During the deformation, older structures in the Archean gneisses were partly transposed (Maass, 1983), but the extent to which the structures were transposed is equivocal.

\section{Middle Proterozoic Midcontinent Rift System}

The youngest major geologic terrane in the region, the Keweenawan (formed 1,100 Ma) Midcontinent rift system, is an intracontinental assemblage of igneous and sedimentary rocks that formed in a rift that aborted before significant crustal separation was achieved (fig. $4 C$ ). The rocks are dominantly (1) bimodal basalt and rhyolite, which occupy a central horst; (2) gabbroanorthosite complexes (Weiblen and Morey, 1980; Weiblen, 1982) which were intruded along the unconformity along the margins of the rift between Archean and (or) Early Proterozoic rock and the younger Keweenawan lavas; and (3) red-bed sedimentary rocks. The basalt is an aluminum-rich olivine tholeiite having a composition typical of large plateau lava provinces (Green, 1983). Chemically, the olivine basalt resembles ocean ridge basalt, but it differs in that it has slightly lightrare-earth-enriched REE patterns and contains high alumina. Large cumulate bodies, such as the Duluth
Complex in Minnesota, are the dominant intrusive rocks associated with the lavas; but basaltic dike swarms, diabase sills, granophyre, and granite are also present. The sedimentary rocks consist of an older, well-indurated succession in basins within the medial part of the rift system, and a younger, less indurated succession along the rift margins, in half-grabens. The well-indurated sedimentary rocks include the Copper Harbor Conglomerate, which formed as volcanism waned, and the succeeding Nonesuch Shale, which was deposited in a large anoxygenic lake.

\section{SUMMARY OF TECTONIC EVOLUTION}

The geologic history of the region during the Archean is speculative. Knowledge of the original size and extent of the 3,500 Ma gneiss terrane is fragmental, but clearly it formed a protocontinental mass of at least several hundred square kilometers. Quite possibly, it was continuous with the ancient gneisses in Labrador and West Greenland. The principal protolith of the gneisses in the Lake Superior region probably was volcanic rocks and associated intrusive rocks (Sims and others, 1984a), but pelitic rocks are a component of the gneisses in the Minnesota River Valley (Grant, 1972) and, if the gneisses in West Greenland were a part of the terrane, ironformation also was a locally significant component (Windley, 1977). Thus, except perhaps for tectonic style, it is probable that geologic processes operative in Early Archean time were not appreciably different from those of today.

About 800 m.y. later, vast quantities of submarine mafic to felsic lavas and associated pyroclastics and volcanogenic graywackes-with attendant voluminous granitoid plutons-were added in repeated cycles along the northern margin (present coordinates) of the older sialic mass. The volcanic-sedimentary pile and associated granitoid rocks were developed in 50-100 m.y., about 2,700 Ma. Evidence is lacking for a sialic crust beneath the greenstone belts in the Great Lakes region, and the rocks are presumed to have accumulated on oceanic crust (Sims and Peterman, 1981). The greenstone-granite complexes were formed in an orogenic environment, probably analogous to modern oceanic-arc complexes. Something of the nature of the boundary (suture) between the two Archean crustal segments (Sims and others, 1980) has been determined by a recent seismic reflection study (Gibbs and others, 1984). The study showed that a shallow north- to northwest-dipping reflection zone, among many others, projects to the surface near the trace of the boundary, as mapped previously (Sims and others, 1980). The shallow-dipping reflection zones are interpreted by Gibbs and colleagues as probably being thrust faults resulting from a Late Archean collision between 
the greenstone-granite terrane (Superior province) and the older gneiss terrane on the south; possibly they are mylonite zones.

During the interval between stabilization of the crust-termination of the Archean, about 2,500 Maand deposition of the Early Proterozoic rocks of the Marquette Range Supergroup and its equivalents in Minnesota-probably beginning about $2,100 \mathrm{Ma}$-the tectonic regime in the Lake Superior region was dominantly extensional. Abundant northwest-trending gabbroic dikes of probably two ages transect the Archean basement in northern Minnesota (Southwick and Day, 1983) and predate the Animikie Group and, possibly, all of the Early Proterozoic sedimentary succession. An older set is about 2,200 m.y. old (K-Ar method; Hanson and Malhotra, 1971), and a younger set has a $\mathrm{Rb} / \mathrm{Sr}$ isochron age of 2,120 $\pm 67 \mathrm{Ma}$ (Beck and Murthy, 1982). In the Lake Huron area, mafic dikes about $2.1 \mathrm{Ga}$ cut the Huronian Supergroup, indicating that this sequence is mostly, if not entirely, older than the Marquette Range Supergroup.

Extension culminated in the Lake Superior region with deposition of a thick (in part $>6 \mathrm{~km}$ ) wedge-shaped succession (Marquette Range Supergroup) of dominantly craton-derived clastic sediments (fig. $4 A$ ). The Early Proterozoic basin formed over and along the profound structural zone (Great Lakes tectonic zone) marked by the suture between the two Archean basement terranes; a clastic wedge was also deposited over the rifted continental margin to the south as a result of passive-margin subsidence. In Michigan and northwest Wisconsin, abundant bimodal volcanic rocks accumulated with the clasticwedge sediments over rifted gneissic crust.

A recent tectonic model of Schulz and others (1984) suggests the following. The breakup of the continent as a consequence of Early Proterozoic rifting led to oceanic spreading, northward-facing subduction along the southern margin of the rifted fragment, and the formation of a volcanic arc (Chippewa-Wausau volcanic belt, fig. 5). Continuing consumption of oceanic crust led to collision of the arc with an Archean microcontinent(?) on the south (now within the Marshfield-Stevens Point belt). Upon reversal in the polarity of subduction, a second arc terrane (Ladysmith-Pembine belt) was developed above the subduction zone, and subsequent closing of the ocean basin resulted in collision of the arc with the continental margin sequence and Archean crust on the north. As noted earlier, it is not known whether the Archean microcontinent(?) associated with the Marshfield-Stevens Point belt is a rifted fragment from the North American continent or an exotic block.

The sequence of Early Proterozoic events outlined above is based on age relations established in the field. The actual time span from crustal breakup to suturing of the ocean-arc complexes with the continental margin is estimated to exceed 50 m.y., and it may well have been longer.

Because of moderately good exposures of rocks composing the Midcontinent rift system in the vicinity of Lake Superior, its pronounced gravity and magnetic signatures, and a lengthy period of intensive study (see Wold and Hinze, 1982), this rift system has been well documented as a major intracratonic rift. The actual nature and stages of development of the rift are controversial, but in the main, eruption of voluminous flood basalts-apparently in nine separate plateaus-was followed by felsic volcanism, subsidence, and sedimentation. At some stage during sedimentation, compressional tectonism commenced, producing major high-angle strike faults with reverse displacement on either side of a central horst. Sedimentation and faulting then continued concurrently for some time (Green, 1983). Van Schmus and others (1982) concluded that rifting and associated igneous activity began 1,200-1,225 Ma, peaked at 1,100 Ma, and ceased shortly thereafter; but widely disparate published radiometric ages suggest that evolution of the rift system may have spanned a longer interval of time.

Since sometime in the Late Proterozoic, the region has been stable, and except for the effects of Pleistocene glaciation, it apparently has been in isostatic equilibrium.

\section{METALLOGENY}

Major mineral deposits occur in each of the terranes except the Archean gneiss. Iron-formation has overwhelmingly been the principal source of metallic ore in the Lake Superior region, the total production having a value of about $\$ 20$ billion. Copper has also been an important metal produced in this region, the output coming entirely from the Keweenaw Peninsula, Michigan. Other major types of deposits, as yet unmined, are volcanic-hosted massive sulfide deposits in the Early Proterozoic Wisconsin magmatic terrane and gabbro-hosted copper-nickel deposits in the Middle Proterozoic (Keweenawan) Duluth Complex, Minnesota. Uranium has been by far the principal ore produced in the Lake Huron region. Without exception, the major deposits were formed synchronously with, or shortly after, formation of the enclosing rocks, although secondary processes of enrichment were important in deposits such as the iron-formations.

The known or potential ore deposits can be grouped into two classes according to the tectonic environment in which they were formed: island-arc crust and continental crust. This format is used in describing the mineraldeposit types below.

Two terranes in the Lake Superior region are underlain by former island-arc, or simatic, crust: the Early 
Proterozoic Wisconsin magmatic terrane and the Archean greenstone-granite terrane. The terranes underlain by continental, or sialic, crust are the Archean gneiss terrane and its partial cover, the Early Proterozoic epicratonic sequence, and the Midcontinent rift system. The Midcontinent rift system is a major intracratonic feature, bounded by continental crust, but its contained mineral deposits are mainly chalcophile elements ultimately derived from the Earth's mantle. The deposits, therefore, have atfinities with those formed in island-arc and oceanic crusts. Except for a rather small iron-formation deposit in central Wisconsin, the Archean gneisses are virtually devoid of mineral deposits of economic value.

\section{Deposits in Island-Arc Crustal Terranes}

Four types of major mineral deposits occur in island-arc crust, as noted in table 1, only one of which is common to both the Early Proterozoic Wisconsin magmatic zone and the Archean greenstone-granite terrane: volcanic-hosted $\mathrm{Cu}-\mathrm{Zn}$ type massive sulfide deposits. The other major deposits apparently are restricted to Archean rocks. The metallogeny is dominated by siderophile elements of the greenstone association.

Table 1. Mineral deposits in island-arc crust, Lake Superior region

[do, same as above entry]

\begin{tabular}{|c|c|c|}
\hline Deposit type & Terrane & Age \\
\hline $\begin{array}{l}\text { Volanic-hosted } \mathrm{Cu}-\mathrm{Zn} \\
\text { type massive sulfide. }\end{array}$ & $\begin{array}{l}\text { Greenstone-granite } \\
\text { Wisconsin magmatic }\end{array}$ & $\begin{array}{l}\text { Late Archean. } \\
\text { Early Protero- } \\
\text { zoic. }\end{array}$ \\
\hline $\begin{array}{l}\text { Algoma-type iron- } \\
\text { formation. }\end{array}$ & Greenstone-granite & Late Archean. \\
\hline $\begin{array}{l}\text { U1tramafic- and gabbro- } \\
\text { hosted } \mathrm{Cu}-\mathrm{Ni} \text {. }\end{array}$ & --- do-- & Do. \\
\hline $\begin{array}{l}\text { Stratabound- and in- } \\
\text { trusion-hosted gold. }\end{array}$ & 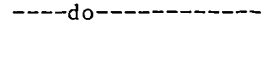 & Do. \\
\hline
\end{tabular}

\section{Massive Sulfide Deposits}

At least four significant massive sulfide deposits are known from the Wisconsin magmatic terrane (Afifi and others, 1984); no potentially minable massive sulfide deposits have been reported from the United States segment of the Archean greenstone-granite terrane (Superior province), but several world-class deposits are known in adjacent Ontario, Canada (Franklin and Thorp, 1982), most notably the incredibly rich Kidd Creek deposit.

The known massive sulfide deposits in northern Wisconsin are in the Ladysmith-Pembine belt of the Wisconsin magmatic terrane (fig. 5). The deposits belong to the primitive type of $\mathrm{Zn}$-Cu massive sulfide deposits of Hutchinson (1980). Characteristics of the deposits are listed in table 2. The Crandon deposit is by far the largest and most extensively studied of the four deposits (May and Schmidt, 1982). This deposit is a steeply dipping, tabular, stratabound body composed of massive sulfide ore and an underlying zone of stringer ore. The tabular, massive sulfide ore contains abundant pyrite and lesser sphalerite, chalcopyrite, and galena, as well as trace amounts of tetrahedrite-tennantite and arsenopyrite. It occurs within a unit of fine-grained pyritic tuff and associated sedimentary rocks. The footwall stringer ore, which makes up about half of the reserves, is composed of pyrite and chalcopyrite, and has subordinate sphalerite, galena, and arsenopyrite. It occurs in brecciated, silicified, and sericitized dacite and andesite pyroclastic rocks. The hanging-wall rocks are tuffs, mainly of dacitic composition. Within the oxidized zone of the subcrop, the primary sulfides have been altered by supergene processes to limonite. In contrast, the Flambeau deposit at Ladysmith has an extensive supergene-enriched zone, which is preserved under a local capping of Cambrian sandstone (May, 1977). The host rocks for all the deposits are calc-alkaline volcanic rocks having overall island-arc chemical affinities.

Table 2. Characteristics of massive sulfide deposits in the Wisconsin magmatic terrane

[Data modified from Mudrey, 1979; na, not available; Tr., trace]

\begin{tabular}{|c|c|c|c|c|c|c|c|}
\hline \multirow[t]{2}{*}{ Deposit } & \multirow{2}{*}{$\begin{array}{l}\text { Reserves } \\
\text { (millions } \\
\text { of tons) }\end{array}$} & $\mathrm{Zn}$ & $\mathrm{Cu}$ & $\mathrm{Pb}$ & $\mathrm{Au}$ & $\mathrm{Ag}$ & \multirow{2}{*}{$\begin{array}{l}\text { Estimated } \\
\text { life } \\
\text { in years }\end{array}$} \\
\hline & & \multicolumn{3}{|c|}{ (percent) } & \multicolumn{2}{|c|}{$(o z / t o n)$} & \\
\hline $\begin{array}{l}\text { F } 1 \text { ambeau } \\
\text { and } \\
\text { Thorn- } \\
\text { apple. }\end{array}$ & $4-6$ & $\mathrm{Tr}$. & $35-40$ & $\mathrm{Tr}$. & 0.05 & 0.53 & $10-20$ \\
\hline Crandon- & 83 & 5 & 1.1 & 0.4 & .03 & .01 & 25 \\
\hline $\begin{array}{l}\text { Pelican } \\
\text { River. }\end{array}$ & 2.2 & 4.5 & 1 & $\mathrm{Tr}$. & Tr. & $\mathrm{Tr}$ & na \\
\hline
\end{tabular}

Although exploration has been extensive and is continuing in the Archean greenstone-granite terrane of northern Minnesota, potentially minable deposits have not been discovered, so far as known. The deposits can be expected to have the general characteristics listed by Franklin and Thorpe (1982) for massive sulfide deposits in the Superior province of Canada. A major attempt to characterize REE (rare-earth-element) patterns of felsic volcanic rocks associated with $\mathrm{Cu}-\mathrm{Zn}$ type massive sulfide deposits in the Superior province, Canada, has indicated that some of these rhyolites are of tholeiitic affinity; they form the felsic members of a bimodal volcanic sequence, and are commonly underlain by subvolcanic intrusions. 
Other ore-associated rhyolites are calc-alkaline (Campbell and others, 1982). The rhyolites of tholeiitic affinity are characterized by relatively flat chrondite-normalized REE patterns, strong Eu anomalies, and high incompatible-trace-element contents (Lesher and others, 1981). This technique for determining the chemical affinity of ore-associated rhyolites is a potentially powerful regional prospecting tool in greenstone-granite terranes.

\section{Algoma-Type Iron-Formations}

Algoma-type iron-formations, originally defined by Gross (1965), have been important sources of iron ore from the Archean greenstone-granite terrane in northern
Minnesota (Sims, 1972) and adjacent Canada (Franklin and Thorpe, 1982). Several deposits have been mined in the Vermilion district of Minnesota from near Ely (fig. 6 ). The deposits are smaller, less continuous, and more irregular in thickness and iron content than the Superiortype iron-formations of Early Proterozoic age in the region. The ore at the major (Soudan) mine in the Vermilion district is of "lump" grade, being a massive, hard, bluish-gray, nearly pure hematite. The hematite ore is an enriched iron ore formed by hydrothermal processes (Gruner, 1926) from dominantly magnetite-bearing banded iron-formation of cherty oxide type. The iron-formations in the Vermilion district are associated with volcanic rocks-both basalt flows and pyroclastic deposits - as well as with epiclastic sedimentary rocks, some of which are carbonaceous; and thus

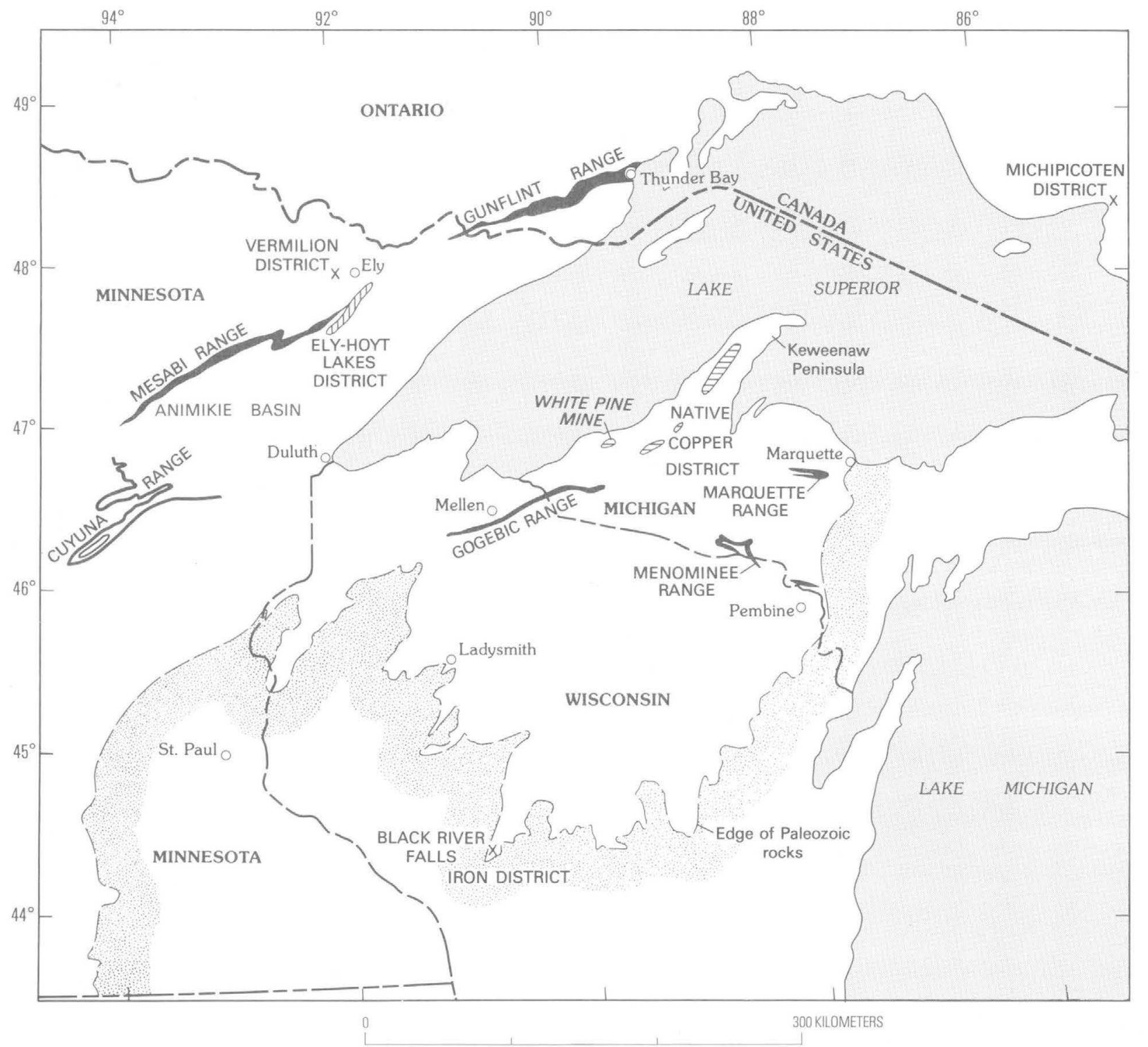

Figure 6. Map of Lake Superior region, showing major known and potential metallic mineral districts in Precambrian rocks. Horizontal rule, known mining district; vertical rule, potential mining district; black pattern, iron-formation. 
these iron-formations are clearly distinguished from the Superior-type iron-formations, which lack any obvious volcanic relation. As pointed out by Gole and Klein (1981), however, the two types of deposits otherwise have many striking similarities in textures and structures. Algoma-type iron-formations are exhalative-type deposits that were formed during lulls in the volcanism, commonly at the completion of a volcanic cycle. The iron-formations in northern Minnesota are complexly deformed (Sims and Southwick, $1980 ; 1985$ ) and are metamorphosed to greenschist facies. A few iron-formations in the region are hosted by graywacke turbidites; generally these are smaller and less suitable for mining than the volcanichosted deposits.

\section{Nickel-Copper Deposits}

Nickel-copper deposits in Archean greenstone belts of the Superior province are common (Franklin and Thorpe, 1982) and contribute substantially to Canada's mineral economy, but deposits of economic significance have not been identified in the United States. The deposits are grossly of two types, one being associated with tholeiitic rocks and the other with komatiitic rocks; both rock types are mantle derived. Komatiitic (magnesiumrich) basalts are rather uncommon in Minnesota but occur locally in the Newton Lake Formation (Schulz, 1980).

\section{Gold Deposits}

The Archean greenstone-granite terrane of the Superior province in Canada has yielded more than 4.3 million $\mathrm{kg}$ of gold-a major world producer-from several different types of deposits (Franklin and Thorpe, 1982), but production from this terrane in the United States has been rather small. At least $1,250 \mathrm{~kg}$ of gold has been produced from the Ropes gold mine in northern Michigan (Rossell and Kalliokoski, 1983), and a small amount of gold was produced from a mine on an island in Rainy Lake (Sims, 1972).

The recent discovery of the Hemlo gold deposit at Heron Bay on the north shore of Lake Superior, in Ontario (Muir, 1983), has spurred a major new exploration phase for gold in the Archean rocks of the region. The Hemlo deposit is a large stratabound(?) deposit of exhalative type in felsic to intermediate pyroclastic volcanic host rocks. Reserves of at least $50 \mathrm{t}$ (metric tons) of gold have been reported; the tenor of the ore is reported to be $0.28 \mathrm{oz}$ gold/ton. Molybdenite occurs in approximately equal amounts as the gold in the ore.

With respect to Early Proterozoic island-arc rocks, anomalous gold values have been reported (G. L. LaBerge, oral commun., 1984) from ferruginous chert and associated rocks in a volcanic-sedimentary basin within the Marshfield-Stevens Point belt (fig. 5) in central Wisconsin; the extent and potential significance of the showings, however, are not known.

\section{Deposits in Continental Crustal Terranes}

Early Proterozoic epicratonic rocks, which overlie the composite Archean basement, contain the vast ironformations for which the region is famed (Bayley and James, 1973; Morey, 1983) as well as small, probably uneconomic deposits of carbonate-hosted copper (table 3). In adjacent Canada, major conglomerate-hosted uranium deposits (Robertson, 1976) occur in the Huronian Supergroup, which is a continental margin accumulation (Young, 1984) similar to the Marquette Range Supergroup.

Middle Proterozoic rocks of the Midcontinent rift system contain volcanic- and sedimentary-hosted copper deposits (table 3), which have been mined for more than a century in the Keweenaw Peninsula of Michigan, and gabbro-hosted $\mathrm{Cu}-\mathrm{Ni}$ deposits in the Duluth Complex (Ely-Hoyt Lakes district, fig. 6), a complex which constitutes this country's principal resource of nickel and cobalt for the future.

A small Algoma-type iron-formation has been mined at one locality from the Archean gneiss microcontinent(?) associated with the Wisconsin magmatic terrane in central Wisconsin.

\section{Superior-Type Iron-Formations}

Superior-type iron-formations of Early Proterozoic age have provided more than 96 percent of the 4.6 billion $t$ of iron ore shipped from the Lake Superior region since 1848 (Morey, 1983). The production has come from separate districts, or iron ranges, within the Animikie basin, a depositional basin having an area of more than $200,000 \mathrm{~km}^{2}$, and several other, separate, possibly isolated smaller basins, in Michigan. James (1983) has estimated that the initial amount of Superior-type ironformation in the Lake Superior region was $10^{13} \mathrm{t}$.

Superior-type iron-formations are characteristically thin banded, cherty rocks with iron-rich layers, containing granules or oolites of both chert and iron minerals, and generally lacking clastic material (Gross, 1965). They are associated with quartzite and carbonaceous shale and commonly with dolomite, argillite, and conglomerate as well. Major iron-formations tend to be continuous and commonly extend for several hundreds of kilometers. They differ from Algoma-type iron-formations in lacking any obvious volcanic relation. In nearly all the depositional basins, iron-formation precipitation persisted, at least intermittently, throughout depositional history; the 
Table 3. Mineral deposits in continental crust, Lake Superior and Lake Huron regions

[do, same as above entry]

\begin{tabular}{|c|c|c|c|c|}
\hline Terrane & Deposit type & Host rock & Age & Locality \\
\hline \multirow[t]{3}{*}{$\begin{array}{l}\text { Midcontinent rift } \\
\text { system. }\end{array}$} & $\begin{array}{l}\text { Volcanic-hosted } \\
\text { copper. }\end{array}$ & $\begin{array}{l}\text { Portage Lake } \\
\text { Volcanics of } \\
\text { Keweenawan } \\
\text { Supergrown. }\end{array}$ & Middle Proterozoic & $\begin{array}{l}\text { Keweenaw Peninsula, } \\
\text { Michigan. }\end{array}$ \\
\hline & Shale-hosted copper & $\begin{array}{l}\text { Nonesuch Shale of } \\
\text { Keweenawan } \\
\text { Supergroup. }\end{array}$ & ----do------_- & Do. \\
\hline & $\begin{array}{l}\text { Gabbro-hosted copper- } \\
\text { nicke1. }\end{array}$ & Duluth Complex-- & 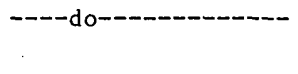 & $\begin{array}{l}\text { E1y-Hoyt Lakes } \\
\text { district, Minnesota. }\end{array}$ \\
\hline \multirow[t]{4}{*}{ Epicratonic rocks } & $\begin{array}{l}\text { Superior-type iron- } \\
\text { formation. }\end{array}$ & Animikie Group-- & Early Proterozoic- & $\begin{array}{l}\text { Mesabi and Cuyuna } \\
\text { ranges, Minnesota. }\end{array}$ \\
\hline & & $\begin{array}{l}\text { Menominee Group } \\
\text { of Marquette } \\
\text { Range Super- } \\
\text { group. }\end{array}$ & $----d o-$ & $\begin{array}{l}\text { Gogebic, Marquette, } \\
\text { and Menominee ranges, } \\
\text { Michigan and Wisconsin. }\end{array}$ \\
\hline & $\begin{array}{l}\text { Carbonate-hosted } \\
\text { copper. }\end{array}$ & $\begin{array}{l}\text { Kona Dolomite } \\
\text { (Chocolay Group) } \\
\text { of Marquette }\end{array}$ & ---- do----- & Northern Michigan. \\
\hline & $\begin{array}{l}\text { Conglomerate-hosted } \\
\text { uranium. }\end{array}$ & $\begin{array}{l}\text { Range Supergroup. } \\
\text { E1liott Lake Group } \\
\text { of Hurontan } \\
\text { Supergroup. }\end{array}$ & --- do------ & $\begin{array}{l}\text { North shore, Lake Huron } \\
\text { region. }\end{array}$ \\
\hline Gneiss-------- & $\begin{array}{l}\text { Algoma-type iron- } \\
\text { formation. }\end{array}$ & $\begin{array}{l}\text { Metavolcanic(?) } \\
\text { rocks. }\end{array}$ & Late Archean- & $\begin{array}{l}\text { Black River Falls, } \\
\text { Wisconsin. }\end{array}$ \\
\hline
\end{tabular}

facies type of iron-formation (James, 1954) appears to be related to local conditions in the basins. There is now widespread acceptance that the source of the iron was the ocean waters, but the mechanism by which iron and silica were withdrawn from the reservoirs is poorly understood.

\section{Carbonate-Hosted Copper Deposits}

The Kona Dolomite, near the base of the Marquette Range Supergroup, contains local stratabound copper deposits. The largest deposit, so far as known, is in the vicinity of Marquette, Mich., but it appears to be too low grade and too cut up by faults to be considered for mining.

\section{Conglomerate-Hosted Uranium Deposits}

Quartz-pebble conglomerates and associated coarse-grained arenites from near the base of the Huronian Supergroup in the Blind River-Elliot Lake-Agnew Lake area, Ontario, Canada, have been a major source of uranium (Robertson, 1976). Between 1955 and 1979, uranium oxide totalling $120,000 \mathrm{t}$ was recovered from the milling of approximately 100 million $t$ of ore. Thirteen mines have been worked at different times. The uraniferous conglomerates are in the Matinenda Formation, and the pay shoots are typically broad paleovalley fillings. Sedimentological studies have shown that the uraninite and associated monazite, pyrite, and zircon are detrital and were transported down the paleoslope from Archean source areas to the northwest. Anoxygenic conditions, which terminated by the end of the Early Proterozoic, were required for the transport and deposition of the uranium-bearing placer minerals.

\section{Volcanic- and Shale-Hosted Copper Deposits}

The copper deposits in the Middle Proterozoic (Keweenawan) rocks of the Keweenaw Peninsula are of two broad types: (1) native copper in amygdaloidal flow tops and conglomerate beds of the Portage Lake Volcanics (White, 1968), and (2) chalcocite and native copper deposits in the Nonesuch Shale at White Pine (Ensign and others, 1968). The former has yielded about 1.5 million tons and the latter about 1 million tons of copper. The principal producing areas for both deposit types are shown in figure 6 .

The native copper deposits in the Portage Lake Volcanics occur primarily as open-space fillings and replacements in flow tops and conglomerate. Both primary permeability and tectonic fracturing controlled the distribution of the copper ore shoots. White (1968) proposed that the copper-bearing solutions that formed the deposits were ascending and were derived either from a large concealed intrusion or, more likely, from water driven out of the porous tops of buried lava flows when the rocks were compacted and metamorphosed (to prehnite-pumpellyite facies). Concentrations of copper have been found associated with lava flows in other areas 
in the Lake Superior region, but apparently none of these are of economic significance.

The shale-hosted copper deposit in the Nonesuch Shale is stratabound, although slightly cross cutting on a regional scale, is continuous over an area of several tens of square kilometers, and contains chalcocite as the dominant copper mineral (Ensign and others, 1968). It is grossly similar to the Kupferschiefer deposits of Paleozoic age in Germany and Poland. A major factor controlling the form and location of ore bodies is a favorable host (darkgray or black, laminated shale). Apparently organic matter had a direct role in localizing ore. White (1971) has proposed an elegant paleohydrologic model to account for the mineralization in the White Pine deposit. This model involves the lateral migration of fluids through the subjacent Copper Harbor Conglomerate to the site of the deposit and the precipitation of copper from these solutions where they percolated upward through the carbonaceous Nonesuch Shale.

Another large area of Nonesuch Shale in northwestern Wisconsin (Morey and others, 1982) has been unsuccessfully explored for copper deposits.

\section{Gabbro-Hosted Copper-Nickel Deposits}

The Duluth Complex, of Keweenawan age, in northeastern Minnesota (Weiblen and Morey, 1980), constitutes an enormous untapped nickel resource and a substantial copper resource. Cobalt and platinum-group elements are important potential byproducts. Estimates of the magnitude of the resource indicate the existence of several billion tons of marginal- and low-grade copperand nickel-bearing material (see Sims, in press, for a summary). An unfavorable metal market and environmental concerns have hampered development of any of the deposits.

Copper- and nickel-bearing sulfides are dispersed widely in the lower, western part of the Duluth Complex and are concentrated locally into bodies of potential economic significance. The major deposits that have been delineated by drilling are in the Ely-Hoyt Lakes district, outlined in figure 6 . The principal concentrations are in troctolite, commonly in the vicinity of inclusions of older argillite. Basinlike depressions and growth faults are favorable structures that have localized a part of the oremineral concentrations. The ore minerals-mainly pyrrhotite, chalcopyrite, cubanite, and pentlandite-are disseminated in the host rock. Semimassive ore has been delineated in one potential ore body (Listerud and Meineke, 1977). The magma generally is interpreted as the source of the metals; most of the sulfur is believed to have been derived from a crustal source, probably the Early Proterozoic Virginia Formation (Mainwaring and Naldrett, 1977). Naldrett (1981) assigned the deposit to his class of "Intrusions feeding flood basalt activity associated with intra-continental rift zones." The magma was derived directly from the mantle.

\section{Algoma-Type Iron-Formation}

In central Wisconsin, Algoma-type iron-formation of presumed Archean age has been mined at one locality (Maass and Van Schmus, 1980), the Jackson County iron mine, east of Black River Falls (fig. 6). The ironformation is a banded magnetite-hematite rock that differs greatly from iron-formations in the greenstonegranite terrane of northern Minnesota in being metamorphosed to middle amphibolite grade (Jones, 1978). It is interbedded with granitic and migmatitic gneisses, schistose greenstone, and metasedimentary rocks, which are intruded by massive granite, aplite, and metadiabase dikes (Harry Klemic, written commun., 1970).

\section{SUMMARY OF TECTONIC EVOLUTION AND MINERALIZATION}

A tectono-stratigraphic approach to metallogeny provides a framework within which to relate existing and possible undiscovered mineral deposits to their enclosing rocks and, with a proper understanding of regional geologic evolution, to possible plate tectonic regimes.

Knowledge of the construction and assembly of the several Archean and Proterozoic terranes in the Lake Superior region-and thus of the environment of mineralization-decreases with increasing age of rocks. The Middle Proterozoic $(\approx 1,225-1,100 \mathrm{Ma})$ Midcontinent rift system is recognized as a classic example of an aborted continental rift, but the actual process of development of the rift and its affinity with tectonic analogs elsewhere are still debated (Green, 1983). As a consequence of the rifting, mantle-derived mafic magma ascended into the upper crust, where it reacted with crustal concentrations of sulfur to give rise to magmatic concentrations of nickel and copper sulfides. Naldrett (1981) has likened the $\mathrm{Cu}$ $\mathrm{Ni}$ deposit in the Duluth Complex to the Norilśk-Talnakh $\mathrm{Cu}-\mathrm{Ni}$ deposit in the U.S.S.R., which also lies within a major continental rift along the northwestern margin of the Siberian platform. The volcanic- and sedimentaryhosted copper deposits of the Keweenaw Peninsula are secondary concentrations resulting from the leaching of country rocks and the transport and deposition of the metal in favorable lithologic or structural traps (White, 1968; 1971).

Major aspects of the evolution of the Early Proterozoic rocks $(\approx 2,100-1,850 \mathrm{Ma})$ in the region have been controversial (Sims, 1976; Van Schmus, 1976), but there now is a convergence of opinion, if not general agreement, that these rocks formed in a plate tectonic regime, probably analogous to modern tectonic environments. 
The recent model proposed by Schulz and others (1984), a refinement of an earlier one by Cambray (1978), suggests early rifting of the Archean continental margin, spreading, subsequent subduction and formation of a complex volcanic arc, and collision of the arc, first with an Archean microcontinent(?) on the south and then with the continental margin sequence and Archean crust (of northern Michigan) on the north. The collision and related tectonism produced the Penokean orogen at about $1,850 \mathrm{Ma}$.

Superior-type iron-formations were deposited on the passive, rifted margin of the Archean craton under stable conditions, before the beginning of passive-margin subsidence. They were deposited near a transgressing and regressing strandline (White, 1954), probably on a shelf located seaward from the subtidal sandstone facies of the stratigraphically older sandstone (quartzite) deposits (Ojakangas, 1983).

The Cu-Zn-type massive sulfide deposits in the volcanic-plutonic complexes of the Wisconsin magmatic zone accumulated in felsic-intermediate volcanic host rocks that are chemically similar to modern island-arcs, like those of the western Pacific (Schulz, 1984). The local coexistence of tectonically emplaced ultramafic rocks with basalts of mid-ocean ridge chemical affinities further supports such an environment of formation. All the known, potentially economic, massive sulfide deposits occur in the northern, Ladysmith-Pembine volcanic belt, perhaps because of a favorable chemical environment. This belt of volcanic rocks is tentatively interpreted as the younger of the two arc complexes in the Wisconsin magmatic terrane, and it is believed to have formed over a southwarddipping subduction zone.

Still more uncertainty exists in interpreting the environments in which the rocks and mineralization of the Archean terranes respectively were formed and took place. The ancient gneiss terrane is especially enigmatic. Apparently it was part of a protocontinent of substantial size that was metamorphosed at moderately deep crustal levels, to produce the ubiquitous amphibolite and granulite metamorphic facies, then rose vertically(?) to its approximate present level by Late Archean time. The sparsity of economic mineral deposits in this terrane could mean that they were removed by erosion, but it could also mean that few metal deposits were formed or that they were obliterated by subsequent crustal reworking and metamorphism.

The tectonic environment of the Late Archean greenstone-granite complexes is a perplexing problem, but they probably formed in repetitive cycles adjacent to the older gneiss terrane (present coordinates) to the south as continental or oceanic arcs. There was some overlap of deposition onto the sialic gneiss terrane (Sims and others, 1984), but for the most part they probably were deposited on an oceanic floor. Low initial ${ }^{87} \mathrm{Sr} /{ }^{86} \mathrm{Sr}$ values (Sims and Peterman, 1981) are interpreted as indicating massive additions of juvenile, mantle-derived material to the crust by ways of melting, assimilation, and mobilization. A common current postulate is that plate tectonic processes occurred during the Late Archean. The requirements for greater rates of dissipation of mantle heat can be accommodated merely by increasing the number of plates and the rates of subduction. The volcanic rocks have both tholeiitic and calc-alkaline compositions. Most of the felsic volcanic rocks are calc-alkaline, but recently it has been shown (Lesher and others, 1981) that some of the felsic volcanic rocks associated with $\mathrm{Cu}-\mathrm{Zn}$-type massive sulfide deposits in the Superior province are of tholeiitic affinity; they form the felsic members of bimodal volcanic assemblages. These rocks, which have rare-earth-element patterns that differ from those of felsic rocks in apparently barren terranes, are inferred to have been derived from partial melting of associated tholeiitic basalts during the intrusion of and the subsequent fractional crystallization of magmas in high-level chambers (Lesher and others, 1981).

\section{REFERENCES CITED}

Afifi, Afifa, Doe, B.R., Sims, P.K., and Delevaux, M.H., 1984, $\mathrm{U}-\mathrm{Th}-\mathrm{Pb}$ isotope chronology of sulfide ores and rocks in the Early Proterozoic metavolcanic belt of northern Wisconsin: Economic Geology, v. 79, p. 338-353.

Anderson, R.R., and Black, R.A., 1983, Early Proterozoic development of the southern Archean boundary of the Superior province in the Lake Superior region: Geological Society of America Abstracts with Programs, v. 15, no. 6, p. 515 .

Arth, J.G., and Hanson, G.N., 1975, Geochemistry and origin of the early Precambrian crust of northeastern Minnesota: Geochimica et Cosmochimica Acta, v. 39, p. 325-362.

Bayley, R.W., Dutton, C.E., and Lamey, C.A., 1966, Geology of the Menominee iron-bearing district, Dickinson County, Michigan, and Florence and Marinette Counties, Wisconsin: U.S. Geological Survey Professional Paper 513, $96 \mathrm{p}$.

Bayley, R.W., and James, H.L., 1973, Precambrian ironformation of the United States: Economic Geology, v. 68, p. 934-959.

Beck, Warren, and Murthy, V. Rama, 1982, Rb-Sr and $\mathrm{Sm}-\mathrm{Nd}$ isotopic studies of Proterozoic mafic dikes in northeastern Minnesota [abs.]: 28th Annual Institute on Lake Superior Geology, International Falls, Minnesota, p. 5.

Cambray, F.W., 1978, Plate tectonics as a model for the environment of deposition and deformation of the early Proterozoic (Proterozoic X) of northern Michigan: Geological Society of America Abstracts with Programs, v. 10, no. 7, p. 376.

Campbell, I.H., Coad, P., Franklin, J.M., Gorton, M.P., Scott, S.D., Sowa, J.M., and Thurston, P.C., 1982, Rare earth elements in volcanic rocks associated with $\mathrm{Cu}-\mathrm{Zn}$ massive sulphide mineralization-A preliminary report: Canadian Journal of Earth Sciences, v. 19, p. 619-623. 
Cannon, W.F., and Gair, J.E., 1970, A revision of stratigraphic nomenclature for middle Precambrian rocks in northern Michigan: Geological Society of America Bulletin, v. 81, p. 2843-2846.

DuBois, J.F., and Van Schmus, W.R.,1978, Petrology and geochronology of Archean gneiss in the Lake Arbutus area, west-central Wisconsin [abs.]: Abstracts and Proceedings, 24th Annual Institute on Lake Superior Geology, Milwaukee, Wis., p. 11.

Ensign, C.O., Jr., White, W.S., Wright, J.C., Patrick, J.L., Leone, R.J., Hathaway, D.J., Trammell, J.W., Fritts, J.J., and Wright, T.L., 1968, Copper deposits in the Nonesuch Shale, White Pine, Michigan, in Ridge, J.D., ed., Ore deposits of the United States, 1933-1967: American Institute of Mining, Metallurgical, and Petroleum Engineers, Inc., p. 460-488.

Fox, T.P., 1983, Geochemistry of the Hemlock Metabasalt and Kiernan sills, Iron County, Michigan: East Lansing, Mich., Michigan State University M.S. thesis, $81 \mathrm{p}$.

Franklin, J.M., and Thorpe, R.I., 1982, Comparative metallogeny of the Superior, Slave and Churchill provinces, in Hutchinson, R.W., Spence, C.D., and Franklin, J.M., eds., Precambrian sulphide deposits (H.S. Robinson Memorial Volume): Geological Association of Canada Special Paper 25, p. 3-90.

Gibbs, A.K., Payne, Barton, Setzer, Thomas, Brown, L.D., Oliver, J.E., and Kaufman, Sidney, 1984, Seismic-reflection study of the Precambrian crust of central Minnesota: Geological Society of America Bulletin, v. 95, p. 280-294.

Goldich, S.S., and Wooden, J.L., 1980, Origin of the Morton Gneiss, southwestern Minnesota, Part 3, Geochronology, in Morey, G.B., and Hanson, G.N., eds., Selected studies of Archean gneisses and lower Proterozoic rocks, southern Canadian Shield: Geological Society of America Special Paper 182, p. 77-94.

Gole, M.J., and Klein, Cornelius, 1981, Banded iron-formations through much of Precambrian time: Journal of Geology, v. 89 , p. $169-183$.

Grant, J.A., 1972, Minnesota River valley, southwestern Minnesota, in Sims, P.K., and Morey, G.B., eds., Geology of Minnesota-A centennial volume: Minnesota Geological Survey, p. 177-196.

Green, J.C., 1983, Geologic and geochemical evidence for the nature and development of the Middle Proterozoic (Keweenawan) Midcontinent rift of North America: Tectonophysics, v. 94, p. 413-437.

Greenberg, J.K., and Brown, B.A., 1983, Lower Proterozoic volcanic rocks and their setting in the southern Lake Superior district, in Medaris, L.G., Jr., ed., Early Proterozoic geology of the Great Lakes region: Geological Society of America Memoir 160, p. 67-84.

Gross, G.A., 1965, Geology of iron deposits in Canada, Volume 1, General geology and evaluation of iron deposits: Geological Survey of Canada Economic Geology Report $22,181 \mathrm{p}$.

Gruner, J.W., 1926, The Soudan formation and a new suggestion as to the origin of the Vermilion iron ores: Economic Geology, v. 21, p. 629-644.

Hanson, G.N., and Malhotra, R., 1971, K-Ar ages of mafic dikes and evidence for low-grade metamorphism in northeastern Minnesota: Geological Society of America Bulletin, v. 82, p. 1107-1114.
Hutchinson, R.W., 1980, Massive base metal sulphide deposits as guides to tectonic evolution, in Strangway, D.W., ed., The continental crust and its mineral deposits: Geological Association of Canada Special Paper 20, p. 659-684.

James, H.L., 1954, Sedimentary facies of iron-formation: Economic Geology, v. 49, p. 235-293.

1983, Distribution of banded iron-formation in space and time, in Trendall, A.F., and Morris, R.C., eds., Ironformation-Facts and problems: Amsterdam and New York, Elsevier, p. 471-490.

Jones, D.G., 1978, Geology of the iron formation and associated rocks of the Jackson County iron mine, Jackson County, Wisconsin: Madison, Wis., University of Wisconsin M.S. thesis, $117 \mathrm{p}$.

King, P.B., and Edmonston, G.J., 1972, Generalized tectonic map of North America: U.S. Geological Survey Miscellaneous Geologic Investigations Map I-688, scale 1:15,000,000.

LaBerge, G.L., and Myers, P.E., 1983, Precambrian geology of Marathon County, Wisconsin: Wisconsin Geological and Natural History Survey Information Circular 45, 88 p.

1984, Two Early Proterozoic successions in central Wisconsin and their tectonic significance: Geological Society of America Bulletin, v. 95, p. 246-253.

Larue, D.K., and Sloss, L.L., 1980, Early Proterozoic sedimentary basins of the Lake Superior region: Geological Society of America Bulletin, Pt. I, v. 91, p. 450-452.

Lesher, C.M., Campbell, I.H., Coad, P., Franklin, J.M., Gibson, H.L., Goodwin, A.M., Gorton, M.P., Hart, T.R., Sowa, J.M., and Thurston, P.C., 1981, Rare earth elements in felsic volcanic rocks associated with $\mathrm{Cu}-\mathrm{Zn}$ massive sulphide mineralization: Ontario Geological Survey Miscellaneous Paper 113, p. 127-134.

Listerud, W.H., and Meineke, D.G., 1977, Mineral resources of a portion of Duluth Complex and adjacent rocks in St. Louis and Lake Counties, northeastern Minnesota: Minnesota Department of Natural Resources Report 93, $73 \mathrm{p}$.

Maass, R.S., 1983, Early Proterozoic tectonic style in central Wisconsin, in Medaris, L.G., Jr., ed., Early Proterozoic geology of the Great Lakes region: Geological Society of America Memoir 160, p. 85-95.

Maass, R.S., Medaris, L.G., Jr., and Van Schmus, W.R., 1980, Penokean deformation in central Wisconsin: Geological Society of America Special Paper 182, p. 147-157.

Maass, R.S., and Van Schmus, W.R., 1980, Precambrian tectonic history of the Black River Valley: Field trip guidebook 2, 26th Annual Institute on Lake Superior Geology, Eau Claire, Wis., 43 p.

Mainwaring, P.R., and Naldrett, A.J., 1977, Country rock assimilation and the genesis of $\mathrm{Cu}-\mathrm{Ni}$ sulfides in the Water Hen intrusion, Duluth Complex: Economic Geology, v. 72, p. 1269-1284.

May, E.R., 1977, Flambeau-a Precambrian supergene enriched massive sulfide deposit: Geoscience Wisconsin, v. 1, p. 1-26.

May, E.R., and Schmidt, P.G., 1982, The discovery, geology and mineralogy of the Crandon Precambrian massive sulphide deposit, Wisconsin, in Hutchinson, R.W., Spence, C.D., and Franklin, J.M., eds., Precambrian sulphide deposits (H.S. Robinson Memorial Volume): Geological Association of Canada Special Paper 25, p. 447-480. 
Morey, G.B., 1973, Stratigraphic framework of Middle Precambrian rocks in Minnesota, in Young, G.M., ed., Huronian stratigraphy and sedimentation: Geological Association of Canada Special Paper 12, p. 211-249.

1983, Animikie basin, Lake Superior region, U.S.A., in Trendall, A.F., and Morris, R.C., eds., Iron formationFacts and problems: Amsterdam and New York, Elsevier, p. 13-68.

Morey, G.B., and Sims, P.K., 1976, Boundary between two Precambrian W terranes in Minnesota and its geologic significance: Geological Society of America Bulletin, v. 87, p. $141-152$.

Morey, G.B., Sims, P.K., Cannon, W.F., Mudrey, M.G., Jr., and Southwick, D.L., 1982, Geologic map of the Lake Superior region, Minnesota, Wisconsin, and northern Michigan: Minnesota Geological Survey State Map Series S-13, scale $1: 1,000,000$.

Mudrey, M.G., Jr., 1979, The massive sulfide occurrences in Wisconsin: Wisconsin Geological and Natural History Survey Paper 79-2, 20 p.

Muir, T.L., 1983, Geology of the Hemlo-Huron Bay area, in Colvine, A.C., ed., The geology of gold in Ontario: Ontario Geological Survey Miscellaneous Paper 110, p. 230-239.

Naldrett, A.J., 1981, Nickel sulfide deposits-Classification, composition, and genesis, in Sims, P.K., and Skinner, B.J., eds., 75th Anniversary Volume: Economic Geology, p. 628-685.

Ojakangas, R.W., 1983, Tidal deposits in the early Proterozoic basin of the Lake Superior region-The Palms and Pokegama Formations: Evidence for subtidal-shelf deposition of Superior-type banded iron-formation, in Medaris, L.G., Jr., ed., Early Proterozoic geology of the Great Lakes region: Geological Society of America Memoir 160, p. 49-66.

Palmer, E.A., 1980, The structure and petrology of Precambrian metamorphic-rock units, northwestern Marathon County, Wisconsin: Duluth, Minn., University of Minnesota-Duluth M.S. thesis, $127 \mathrm{p}$.

Robertson, J.A., 1976, The Blind River uranium deposits-The ores and their setting: Ontario Division of Mines Miscellaneous Paper 65, 45 p.

Rossell, Dean, and Kalliokoski, Jo, 1983, The Ropes gold mine and its geologic setting: 29th Annual Institute on Lake Superior Geology, Houghton, Michigan, p. 44-74.

Schulz, K.J., 1980, The magmatic evolution of the Vermilion greenstone belt, northeastern Minnesota: Precambrian Research, v. 11, p. 215-245.

1984, Volcanic rocks of northeastern Wisconsin, in Sims, P.K., Schulz, K.J., and Peterman, Z.E., Guide to the geology of the Early Proterozoic rocks in northeastern Wisconsin: 30th Annual Institute on Lake Superior Geology, Field trip 1, p. 51-80.

Schulz, K.J., LaBerge, G.L., Sims, P.K., Peterman, Z.E., and Klasner, J.S., 1984, The volcanic-plutonic terrane of northern Wisconsin-Implications for Early Proterozoic tectonism, Lake Superior region: Geological Association of Canada-Mineralogical Association of Canada, London, Ontario, Canada, Program with abstracts, p. 103.

Sims, P.K., 1972, Mineral deposits in lower Precambrian rocks, northern Minnesota, in Sims, P.K., and Morey, G.B., eds., Geology of Minnesota-A Centennial Volume: Minnesota Geological Survey, p. 172-176.
1976, Precambrian tectonics and mineral deposits, Lake Superior region: Economic Geology, v. 71, p. 1092-1118. in press, History of discovery of copper-nickel deposits in the Duluth Complex, northeast Minnesota, in Hollister, V.F., ed., Case histories of mineral discoveries: Society of Mining Engineers.

Sims, P.K., Card, K.D., and Lumbers, S.B., 1981, Evolution of early Proterozoic basins of the Great Lakes region, in Campbell, F.H.A., ed., Proterozoic basins of Canada: Geological Survey of Canada Special Paper 81-10, p. 379-397.

Sims, P.K., Card, K.D., Morey, G.B., and Peterman, Z.E., 1980, The Great Lakes tectonic zone-A major crustal structure in central North America: Geological Society of America Bulletin, Pt. I, v. 91, p. 690-698.

Sims, P.K., and Peterman, Z.E., 1981, Archean rocks in the southern part of the Canadian Shield-A review: Geological Society of Australia Special Publication 7, p. 85-98.

1983, Evolution of Penokean foldbelt, Lake Superior region, and its tectonic environment, in Medaris, L.G., Jr., ed., Early Proterozoic geology of the Great Lakes region: Geological Society of America Memoir 160, p. 3-14.

1984, A partisan review of the Early Proterozoic geology of Wisconsin and adjacent Michigan [abs.]: 30th Annual Institute on Lake Superior Geology, Wausau, Wis., p. 73-76.

Sims, P.K., Peterman, Z.E., Prinz, W.C., and Benedict, F.C., 1984, Geology, geochemistry, and age of Archean and Early Proterozoic rocks in the Marenisco-Watersmeet area, northern Michigan: U.S. Geological Survey Professional Paper 1292-A, 41 p.

Sims, P.K., Peterman, Z.E., and Schulz, K.J., 1985, The Dunbar Gneiss-granitoid dome-Implications for early Proterozoic tectonic evolution of northern Wisconsin: Geological Society of America Bulletin, v. 96, p. 1101-1112.

Sims, P.K., and Southwick, D.L., 1980, Geologic map of the Soudan quadrangle, St. Louis County, Minnesota: U.S. Geological Survey Geologic Quadrangle Map GQ-1540, scale $1: 24,000$.

1985, Geologic map of Archean rocks, western Vermilion district, northern Minnesota: U.S. Geological Survey Miscellaneous Investigations Map I-1527, scale 1:48,000.

Southwick, D.L., and Day, W.C., 1983, Geology and petrology of Proterozoic mafic dikes, north-central Minnesota and western Ontario: Canadian Journal of Earth Sciences, v. 20, p. 622-638.

Van Schmus, W.R., 1976, Early and middle Proterozoic history of the Great Lakes area, North America: Royal Society of London Philosophical Transactions, ser. A280, no. 1298, p. 605-628.

Van Schmus, W.R., and Anderson, J.L., 1977, Gneiss and migmatite of Archean age in the Precambrian basement of central Wisconsin: Geology, v. 5, p. 45-48.

Van Schmus, W.R., Medaris, L.G., Jr., and Banks, P.O., 1975, Geology and age of the Wolf River batholith, Wisconsin: Geological Society of America Bulletin, v. 86, p. 907-914.

Van Schmus, W.R., Green, J.C., and Halls, H.C., 1982, Geochronology of Keweenawan rocks of the Lake Superior region, in Wold, R.J., and Hinze, W.J., eds., Geology and tectonics of the Lake Superior region: Geological Society of America Memoir 156, p. 165-172. 
Weiblen, P.W., 1982, Keweenawan intrusive igneous rocks, in Wold, R.J., and Hinze, W.J., eds., Geology and tectonics of the Lake Superior region: Geological Society of America Memoir 156, p. 57-82.

Weiblen, P.W., and Morey, G.B., 1980, A summary of the stratigraphy, petrology and structure of the Duluth Complex: American Journal of Science, v. 280-A, p. 88-133.

White, D.A., 1954, Stratigraphy and structure of the Mesabi range, Minnesota: Minnesota Geological Survey Bulletin $38,92 \mathrm{p}$.

White, W.S., 1968, The native copper deposits of northern Michigan, in Ridge, J.D., ed., Ore deposits of the United States, 1933-1967: American Institute of Mining, Metallurgical, and Petroleum Engineers, Inc., p. 303-326.
1971, A paleohydrologic model for mineralization of the White Pine copper deposit, northern Michigan: Economic Geology, v. 66, p. 1-13.

Windley, B.F., 1977, The evolving continents: New York, John Wiley, 385 p.

Wold, R.J., and Hinze, W.J., 1982, Introduction, in Wold, R.J., and Hinze, W.J., eds., Geology and tectonics of the Lake Superior region: Geological Society of America Memoir 156, p. 1-4.

Young, G.M., 1984, The Huronian Supergroup-An example of an Early Proterozoic passive margin sequence [abs.]: 30th Annual Institute on Lake Superior Geology, Wausau, Wis., p. 80. 
Chapter F

\title{
Sodium Hypochlorite as an Aid to the Extraction of Clay Minerals from Black Shales
}

\author{
BY HARRY C. STARKEY
}




\title{
CONTENTS
}

\author{
Abstract 77 \\ Introduction 77 \\ Experimental method $\mathbf{7 8}$ \\ Results and discussion $\mathbf{7 9}$ \\ References cited $\mathbf{8 0}$
}

\section{FIGURE}

1. Diagram showing weight loss of sodium hypochlorite- and distilled-watertreated black shale samples compared to number of treatments

\section{TABLES}

1. Weight loss from sodium hypochlorite versus distilled-water treatments compared with partial data on total organic carbon content $\mathbf{7 8}$

2. Comparison of particle-size fractionation of black shales treated with sodium hypochlorite and with distilled water $\mathbf{7 9}$ 


\section{Sodium Hypochlorite as an Aid to the Extraction of Clay Minerals from Black Shales}

\author{
By Harry C. Starkey
}

\begin{abstract}
Black shales are important as petroleum source rocks and also may contain heavy minerals. Clay minerals, which may indicate depositional and postdepositional environments, are important shale constituents. Identifying these clay minerals is difficult because the organic matter in the black shales may act as a cementing agent, which makes disaggregating the samples difficult.

A 5.25 percent solution of sodium hypochlorite, adjusted to a $\mathrm{pH}$ of 9.50 , was used as an aid to the disaggregation and dispersion of 17 samples of black shale by removing organic matter prior to the removal of the clay-size fraction. Controls of the same samples were run using distilled water instead of the sodium hypochlorite. In every sample, the amount of sandsize particles was reduced and, in all but one sample, the amount of clay-size particles was increased when the sodium hypochlorite was used. The sodium hypochlorite-treated samples lost an average of 1.7 percent more weight than did the samples treated with distilled water; some of the increased weight loss was probably due to the destruction of organic matter by the sodium hypochlorite. A lightening in the dark color of most samples treated with sodium hypochlorite substantiated this loss of organic matter.

All samples but one showed a greater weight loss with the sodium hypochlorite solution than with the distilled water; the exception, sample 114S, contained gypsum. The differences in the final weights of the samples treated with sodium hypochlorite and those treated with distilled water are less than the experimental error in any particular sample. As all the experimental error is unlikely to be in the same direction, the differences all indicate that more organic matter was removed by the sodium hypochlorite.

Compared to the clay-size fraction after the sodium hypochlorite treatment, only one sample showed a higher clay-size fraction after distilled-water treatment; the difference was 0.4 percent. As this difference is well within the experimental error, the clay-size fraction present after both treatments of this sample is considered to be the same.
\end{abstract}

\section{INTRODUCTION}

Black shales are widespread; more than 200 formations containing black shales were investigated in the
United States between 1944 and 1956 (Swanson, 1961). These shales are organic-rich, fine-grained rocks which may contain heavy metals, and they are also important as petroleum source rocks. Because they are composed of claystones and mudstones, the shales contain abundant clay minerals. These clay minerals may be important indicators of depositional and postdepositional environments. Identification of minerals in shales, especially clay minerals, is often hindered by difficulty in disaggregating the shales in which organic matter as well as silica and carbonates may act as cementing agents (van Langeweld and others, 1978; Sterne and others, 1982). To study the clay minerals, enough clay must be separated to make randomly oriented powder mounts and oriented aggregates for X-ray powder diffraction analysis. Removing cementing agents such as organic matter from shales facilitates the disaggregation necessary for particle-size analysis, for heavy-minera! extraction, and for the extraction of clay minerals for identification.

This report discusses a method of removing organic material from black shales to increase the proportion of the clay-size fraction resulting from disaggregation and thus the amount of clay minerals extracted. Removing silica or carbonate cements may further increase the amount of clay minerals extracted, but the chemicals used for removing these cements may attack the clay minerals also.

Hydrogen peroxide was often used in the past to remove organic material from geologic samples, but it produced some undesirable side effects such as the formation of calcium oxalate phases (Martin, 1954; Jones and Beavers, 1963), the dissolution of carbonates, and the partial dissolution of the clay minerals. Douglas and Feissinger (1971) demonstrated that the dissolution of clay minerals during hydrogen peroxide treatment could be reduced somewhat by using a sodium acetate buffer.

Cassidy and Mankin (1960) proposed using sodium hypochlorite to remove organic matter from black shales. Their method consisted of boiling the sample for as much as 3 hours in a 5 percent solution of sodium hypochlorite (pH 12.1). This method effectively removed most of the organic matter from the shales, but some of the clay 
minerals were attacked, especially when the treatment was prolonged. Kaolins were subject to attack by the highpH solutions, particularly if the solutions became concentrated through evaporation by boiling. The solutions were so strong that Cassidy and Mankin cautioned against the use of glass beakers because the concentrated solutions would attack them.

More recently, sodium hypochlorite has been used to destroy organic matter in soils (Anderson, 1963; Omueti, 1980). In a comparative study of the effectiveness of the sodium hypochlorite and the hydrogen peroxide methods of organic matter destruction, Lavkulich and Wiens (1970) found that the sodium hypochlorite, when used according to Anderson's method, destroyed more organic material while removing fewer inorganic cations than did the hydrogen peroxide.

Anderson (1963) used calcium- and phosphorusfree sodium hypochlorite and Omueti (1980) used sodium hypochlorite (commercial bleach) adjusted to $\mathrm{pH} 9.5$ to remove organic matter from soil samples. The $\mathrm{pH}$ of that solution is less destructive of the silica and alumina in the clay minerals than is the higher $\mathrm{pH}$ (12.1) of the unadjusted sodium hypochlorite. They used shorter reaction times and lower temperatures than did Cassidy and Mankin (1960): they heated the samples for only $15 \mathrm{~min}$ over a steam bath, after which they removed the spent sodium hypochlorite solution and replaced it with fresh solution. They then repeated the process twice.

\section{EXPERIMENTAL METHOD}

Seventeen black shales were prepared by grinding to -100 mesh. The shales used in this study were very fine grained, and this amount of grinding should not have produced much crystal fracturing. Grinding to such a small size was deemed desirable in order to allow better penetration of the sample by the solutions and thus reduce the number of treatments. Duplicate 1-g (gram) samples were taken; one to be treated with sodium hypochlorite, and the other to be treated, as a control, with distilled water in the same manner.

A 1-g sample of each shale was placed in $40-\mathrm{mL}$ (milliliter) centrifuge tubes with $5-\mathrm{mL}$ sodium hypochlorite solution. The sodium hypochlorite solution used was commercial household laundry bleach containing 5.25 percent sodium hypochlorite and freshly adjusted to a $\mathrm{pH}$ of 9.5 with hydrochloric acid. The centrifuge tube was then placed in a steam bath and heated for $15 \mathrm{~min}$. After removal from the steam bath, the sample was treated ultrasonically for $5 \mathrm{~min}$, allowed to settle for $\mathbf{1 0}$ min, and the suspended material was decanted and retained. Five milliliters of fresh solution was added to the sample, and the procedure was repeated several times until the supernatant was clear after the 10-min settling time. All the supernatants from each sample were combined, and the number of treatments recorded. The sodium hypochlorite solution was removed from the suspended material in the combined supernatants by vacuum through bacteriological filter candles (Starkey and others, 1984). The suspended material was washed with distilled water, which then was removed by filter candles. After washing, this suspended material was recombined with the material that had settled out.

This method did not remove all the organic matter (table 1), nor did it completely disaggregate all of the shales, but it did free enough of the clay minerals for study. For this study, the samples were separated after treatment into sand, silt, and clay-size fractions to demonstrate the changes in particle-size distribution. The method of particle-size fractionation was that described by Starkey and others (1984) in which the sand is removed by wet sieving through a 230 -mesh sieve and the clay and silt were separated by centrifugation.

Table 1. Weight loss from sodium hypochlorite versus distilled-water treatments compared with partial data on total organic carbon content

[All values in weight percent; n.d., not determined]

\begin{tabular}{cccc}
\hline $\begin{array}{c}\text { Sample } \\
\text { No. }\end{array}$ & $\begin{array}{c}\text { NaOCl } \\
\text { treatment }\end{array}$ & $\begin{array}{c}\mathrm{H}_{2} \mathrm{O} \\
\text { treatment }\end{array}$ & $\begin{array}{c}\text { Total } \\
\text { organic carbon }\end{array}$ \\
\hline $29 \mathrm{~S}$ & 3.2 & 1.4 & $\mathrm{n} . \mathrm{d}$. \\
$30 \mathrm{~S}$ & 4.2 & 0.8 & $\mathrm{n} \cdot \mathrm{d}$. \\
$33 \mathrm{~S}$ & 3.1 & 1.9 & $\mathrm{n} \cdot \mathrm{d}$. \\
$35 \mathrm{~S}$ & 1.0 & 1.2 & $\mathrm{n} . \mathrm{d}$. \\
$46 \mathrm{~S}$ & 3.6 & 2.3 & $\mathrm{n} . \mathrm{d}$. \\
$7 \mathrm{~S}$ & 3.8 & 2.5 & $\mathrm{n} . \mathrm{d}$. \\
$90 \mathrm{~S}$ & 3.2 & 1.2 & $\mathrm{n} . \mathrm{d}$. \\
$100 \mathrm{~F}$ & 4.2 & 3.2 & 15.41 \\
$100 \mathrm{~S}$ & 4.0 & 3.9 & 14.86 \\
$110 \mathrm{~S}$ & 4.4 & 2.1 & 6.84 \\
$114 \mathrm{~S}$ & 4.8 & 7.4 & 23.43 \\
$119 \mathrm{~S}$ & 4.2 & 2.9 & 12.03 \\
$132 \mathrm{~S}$ & 3.8 & 2.0 & 13.27 \\
$135 \mathrm{~S}$ & 4.4 & 1.6 & 6.08 \\
$303 \mathrm{~S}$ & 3.6 & 0.8 & $\mathrm{n} . \mathrm{d}$. \\
$311 \mathrm{~S}$ & 4.4 & 2.2 & n.d. \\
$562 \mathrm{~S}$ & 3.0 & 2.2 & 2.9 \\
\hline
\end{tabular}

$1_{\text {Total }}$ organic carbon data furnished by F.G. Poole, U.S. Geological Survey.

To ascertain how much of the disaggregation achieved was caused by the sodium hypochlorite treatment rather than the ultrasonic treatment, duplicate samples were treated in the same manner, but distilled water was used in place of the sodium hypochlorite. The number and duration of the treatments were repeated with the distilled water, and the size fractions were separated by the same method already referred to (Starkey and others, 1984). 


\section{RESULTS AND DISCUSSION}

The results obtained from this study show that sodium hypochlorite is an effective aid for removing organic matter from black shales. Although the sodium hypochlorite does not remove all the organic matter, it removes enough to increase the quantity of clay-size particles obtained without adverse effects on the clay minerals.

The results of the particle-size fractionation of the samples after treatment with sodium hypochlorite and with distilled water are given in table 2 . For all samples except one, the clay-size fractions were greater in the samples treated with sodium hypochlorite than in those samples treated with distilled water. The one exception was sample $33 \mathrm{~S}$, which produced 0.4 percent more claysize fraction in the sample treated with distilled water. This increase is so slight that it can be attributed to experimental error, and the amount of the clay-size fraction is considered the same for both samples.

Not only was the percentage of the clay-size fraction generally greater after the sodium hypochlorite treatment, but the percentage of the sand-size fraction was decreased. Some of the samples produced more silt with the sodium hypochlorite treatment and some produced less. The percentage of silt produced depended upon whether the sodium hypochlorite was more effective in breaking down the large particles, thus producing silt, or in breaking down the silt, thus producing more clay-size particles.

Samples treated with sodium hypochlorite had a greater overall weight loss than those treated with distilled water (fig. 1). All but one of the sodium hypochlorite-treated samples lost 3.0 weight percent or more, and all but three of the distilled-water-treated samples lost less than 3.0 weight percent. Some weight loss in all samples could be caused by handling and transferring samples. Other weight loss may have been caused by soluble salts that went into solution, or by variations in amounts of adsorbed water.

The greater weight loss in the sodium hypochloritetreated samples was caused by the removal of the organic matter. The difference in weight loss between the sodium hypochlorite-treated and distilled-water-treated (control) samples averaged 1.7 percent, if sample $114 \mathrm{~S}$ is eliminated. This weight loss was accompanied by a general lightening of the color of the black shales that were treated with sodium hypochlorite.

Two samples did not show greater weight loss with the sodium hypochlorite treatment. Sample 35S showed a 0.2 percent greater loss with distilled water than with the sodium hypochlorite treatment, but this amount is negligible, and so the weight loss is basically the same for both treatments. Any color change in sample 35S was

Table 2. Comparison of particle-size fractionation of black shales treated with sodium hypochlorite and with distilled water [All values in weight percent]

\begin{tabular}{|c|c|c|c|c|c|c|c|c|c|}
\hline \multirow{2}{*}{$\begin{array}{c}\text { Sample } \\
\text { No. }\end{array}$} & \multirow{2}{*}{$\begin{array}{l}\text { Number of } \\
\text { treatments }\end{array}$} & \multicolumn{4}{|c|}{5.25 pet $\mathrm{NaOCl}$ solution } & \multicolumn{4}{|c|}{ Distilled water } \\
\hline & & Sand & \multicolumn{3}{|c|}{$($ percent $)$} & Sand & $\begin{array}{c}\operatorname{Silt} \\
(\text { percent })\end{array}$ & Clay & Total \\
\hline $29 S$ & 6 & 30.9 & 46.8 & 19.1 & 96.8 & 31.5 & 66.5 & 0.6 & 98.6 \\
\hline $30 \mathrm{~s}$ & 13 & 20.9 & 53.2 & 21.7 & 95.8 & 31.8 & 50.0 & 17.4 & 99.2 \\
\hline $33 \mathrm{~S}$ & 11 & 15.0 & 66.7 & 15.2 & 96.9 & 18.8 & 63.7 & 15.6 & 98.1 \\
\hline $35 S$ & 8 & 14.0 & 61.0 & 24.0 & 99.0 & 17.8 & 58.4 & 22.6 & 98.8 \\
\hline $46 S$ & 9 & 3.2 & 77.5 & 15.7 & 96.4 & 21.2 & 65.3 & 11.2 & 97.7 \\
\hline $71 \mathrm{~S}$ & 13 & 2.4 & 76.4 & 17.4 & 96.2 & 28.9 & 62.0 & 6.6 & 97.5 \\
\hline $90 \mathrm{~S}$ & 7 & 23.2 & 62.8 & 10.8 & 96.8 & 27.1 & 71.3 & 0.4 & 98.8 \\
\hline $100 \mathrm{~F}$ & 3 & 17.7 & 52.4 & 25.7 & 95.8 & 21.2 & 51.8 & 23.8 & 96.8 \\
\hline $100 \mathrm{~S}$ & 4 & 2.6 & 44.4 & 49.0 & 96.0 & 11.1 & 47.1 & 37.9 & 96.1 \\
\hline $110 \mathrm{~S}$ & 8 & 1.4 & 62.1 & 32.1 & 95.6 & 14.6 & 58.5 & 24.8 & 97.5 \\
\hline $114 S$ & 5 & 27.6 & 40.8 & 26.8 & 95.2 & 30.9 & 39.6 & 22.1 & 92.6 \\
\hline $119 \mathrm{~S}$ & 4 & 21.7 & 42.7 & 31.4 & 95.8 & 25.8 & 44.3 & 27.0 & 97.1 \\
\hline $132 \mathrm{~S}$ & 11 & 13.6 & 68.8 & 13.8 & 96.2 & 28.1 & 66.5 & 3.4 & 98.0 \\
\hline $135 \mathrm{~s}$ & 9 & 7.6 & 43.2 & 44.8 & 95.6 & 24.2 & 43.8 & 30.4 & 98.4 \\
\hline 3035 & 8 & 0.2 & 52.8 & 43.4 & 96.4 & 18.8 & 54.3 & 26.1 & 99.2 \\
\hline 3115 & 11 & 2.6 & 52.8 & 40.2 & 95.6 & 29.2 & 49.0 & 19.6 & 97.8 \\
\hline $562 \mathrm{~S}$ & 10 & 6.6 & 50.0 & 40.4 & 97.0 & 19.9 & 49.8 & 28.1 & 97.8 \\
\hline
\end{tabular}


indiscernible. Sample 114S had a greater weight loss in distilled water because the sample contained gypsum that went into solution. Although it produced a lighter color in the sample, the sodium hypochlorite treatment of sample 114S did not result in as great a weight loss because the commercial sodium hypochlorite solution used in this work contained carbonate anions. These anions combined with the calcium dissolved from the gypsum to form calcite, which was precipitated and weighed with the claysize fraction. If gypsum is present in a sample, and if particle-size distribution is to be determined, it may be necessary to use a purer sodium hypochlorite solution.

Because handling and transferring samples may produce weight loss, a positive correlation between the number of treatments and the total weight loss was expected. Such a correlation was not evident (fig. 1). Apparently the loss of weight due to handling of the samples was minimal.

Sodium hypochlorite, although more efficient than hydrogen peroxide in removing organic matter, must only be considered as an aid to the disaggregation of black shales. Available data show that sodium hypochlorite removed only about one-fourth of the organic material from some organic-rich samples (table 1), which increased the amount of clay-size particles by 2-11 percent (table 2). Repetition of the treatment together with removal of

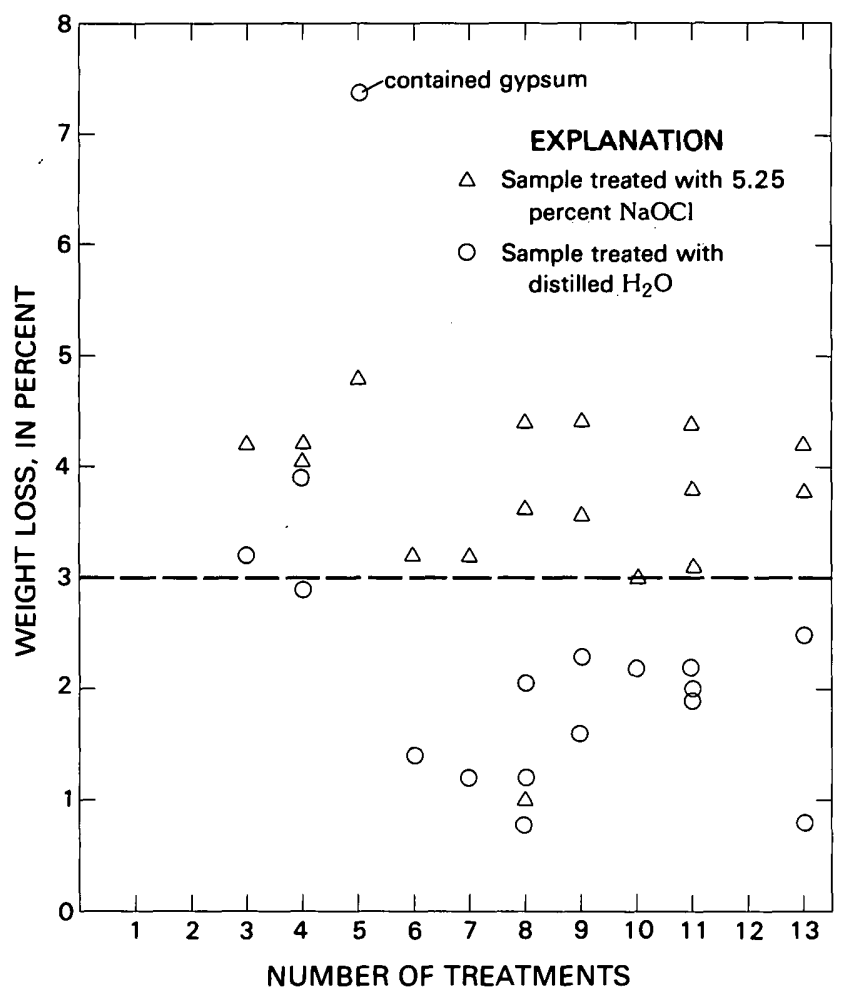

Figure 1. Weight loss of sodium hypochlorite- and distilledwater-treated samples of black shale compared to the number of treatments. Line at 3.0 percent, weight-loss break by treatment. other cementing agents can be expected to free more claysize particles.

The sodium hypochlorite, and possibly solutions of other hypohalous salts, offers several advantages over hydrogen peroxide. When commercial household laundry bleach is used as the sodium hypochlorite solution, the cost is quite reasonable. The sodium hypochlorite is more stable and safer to use than is the hydrogen peroxide, and it is less destructive of clay minerals, an important consideration because the chemical character of the clay minerals may be affected if a part of them is destroyed by the pretreatment. An added advantage to the sodium hypochlorite treatment is that the exchange positions of the clay minerals become sodium saturated, which prevents flocculation and aids in dispersion of the particles (Omueti, 1980).

\section{REFERENCES CITED}

Anderson, J.U., 1963, An improved pretreatment for mineralogical analysis of samples containing organic matter: Clays and Clay Minerals, v. 10, p. 380-388.

Cassidy, M.M., and Mankin, C.J., 1960, Clorox used in preparation of black shale for mineral analysis: Oklahoma Geology Notes, v. 20, no. 11, p. 275-281.

Douglas, L.A., and Feissinger, Francois, 1971, Degradation of clay minerals by $\mathrm{H}_{2} \mathrm{O}_{2}$ treatment to oxidize organic matter: Clays and Clay Minerals, v. 19, no. 1, p. 67-68.

Jones, R.L., and Beavers, A.H., 1963, Silt size whewellite and waddellite by soil peroxidation: Soil Science Society of America Proceedings, v. 27, no. 3, p. 356-357.

Lavkulich, L.M., and Wiens, J.H., 1970, Comparison of organic matter destruction by hydrogen peroxide and sodium hypochlorite and its effects on selected mineral constituents: Soil Science Society of America Proceedings, v. 34 , no. 5 , p. $755-758$.

Martin, R.T., 1954, Calcium oxalate formation in soil from hydrogen peroxide treatment: Soil Science, v. 77 , no. 2 , p. 143-145.

Omueti, J.A.I., 1980, Sodium hypochlorite treatment for organic matter destruction in tropical soils of Nigeria: Soil Science Society of America Journal, v. 44, no. 4, p. 878-880.

Starkey, H.C., Blackmon, P.D., and Hauff, P.L., 1984, The routine mineralogical analysis of clay-bearing samples: U.S. Geological Survey Bulletin 1563, 32 p.

Sterne, E.J., Reynolds, R.C., Jr., and Zantop, Half, 1982, Natural ammonium illites from black shales hosting a stratiform base metal deposit, DeLong Mountains, northern Alaska: Clays and Clay Minerals, v. 30, no. 3, p. 161-166.

Swanson, V.E., 1961, Geology and geochemistry of uranium in marine black shales, a review: U.S. Geological Survey Professional Paper 356-C, p. 67-112.

van Langeveld, A.D., van der Graast, S.J., and Eisma, D., 1978, A comparison of the effectiveness of eight methods for the removal of organic matter from clay: Clays and Clay Minerals, v. 26, no. 5, p. 361-364. 
Chapter G

\section{Platinum and Palladium in a Mafic Dike, Sanders County, Montana} By R.E. VAN LOENEN, JOSEPH HAFFTY, and R.L. EARHART

Hydrothermal activity has concentrated platinum and palladium in a mafic intrusive body of Late Proterozoic age

U.S. GEOLOGICAL SURVEY BULLETIN 1694

CONTRIBUTIONS TO MINERAL RESOURCES RESEARCH, 1984 


\title{
CONTENTS
}

\author{
Abstract 83 \\ Introduction $\mathbf{8 3}$ \\ Acknowledgments 83 \\ Geologic setting 83 \\ Sampling and analysis 85 \\ Dike composition 85 \\ Mineralization $\mathbf{8 8}$ \\ Metal distribution $\mathbf{8 8}$ \\ Nature of platinum in dike $\mathbf{8 9}$ \\ Summary 89 \\ References cited $\mathbf{8 9}$ \\ FIGURES
}

1. Index map showing mines and sample localities and outcrop pattern of Green Mountain dike 84

2. Histograms showing the number of samples at various concentrations of metals $\mathbf{8 8}$

TABLES

1. Analyses of intrusive rocks from Green Mountain dike $\mathbf{8 6}$ 


\title{
Platinum and Palladium in a Mafic Dike, Sanders County, Montana
}

\author{
By R.E. Van Loenen, Joseph Haffty, and R.L. Earhart
}

\begin{abstract}
Platinum and palladium have been concentrated by hydrothermal activity in altered rocks in and along fractures in the Green Mountain dike, Sanders County, Montana. The Green Mountain dike, a mafic intrusive of Late Proterozoic age, is intruded into metasediments of the Middle Proterozoic Belt Supergroup. Unaltered dike rocks contain slightly more platinum than palladium; however, palladium, the most mobile element of the platinum-group, is enriched in altered rock over platinum by a factor of 2:1. Copper, which follows a similar pattern of enrichment in altered rocks, is closely associated to platinum and palladium. Sperrylite $\left(\mathrm{PtAs}_{2}\right)$ was identified in a sample of altered rock from the dike.
\end{abstract}

\section{INTRODUCTION}

The Green Mountain dike, of Late Proterozoic age, crops out south of the Flathead River in northwest Montana. Minor base metals (mainly copper), gold, and silver were produced from vein deposits in the dike. Since the early mining days the dike was known to contain local occurrences of platinum-group elements, but little has previously been known of their nature of occurrence or mineralogy.

Vein deposits in the dike were mined during a 40-year period from 1910 through 1949. During this time, recorded production amounted to 9,000 tons of ore that contained 1,275 oz of gold, 5,750 oz of silver and $1,400,000 \mathrm{lbs}$ of copper (Crowley, 1963). The amount of platinum and palladium produced is not known, but these metals were probably recovered with gold and were included with the gold.

Several mines were developed along the dike; however, most of the metals produced were from the Green Mountain (Drake) mine (fig. 1).

The Green Mountain dike is about $5 \mathrm{mi}$ south of the Flathead River along the east side of Revais Creek in the southeast part of Sanders County, Montana (fig. 1). Part of the dike is located on the Flathead Indian Reservation. Data for this report are partly from unpublished data in a 1980 U.S. Geological Survey administrative report to the Bureau of Indian Affairs, concerning the mineral and geothermal resources of the Flathead Indian Reservation, by R.L. Earhart, R.E. Van Loenen, and J.W. Whipple. The purpose of the present report is to present analytical data for 99 samples collected from both underground and surface exposures and to discuss the distribution and mode of occurrence of the platinum group metals.

\section{Acknowledgments}

We thank Zane Kelly of Polson, Mont., for assistance in collecting the samples, and G. A. Desborough of the U.S. Geological Survey for assistance with the electron microprobe analysis.

\section{GEOLOGIC SETTING}

The Green Mountain dike was intruded into rocks of the Burke Formation, the lowermost unit of the Ravalli Group of the Belt Supergroup. The Belt Supergroup in this region is more than $40,000 \mathrm{ft}$ thick and consists of fine-grained clastic and carbonate rocks that were deposited rather continuously during Middle Proterozoic time. Regional metamorphism to greenschist to epidoteamphibolite facies converted the strata to argillite, siltite, and quartzite. Mafic sills that intruded into the Belt rocks during Late Proterozoic time are especially abundant in lower parts of the Belt Supergroup of this area. Mafic intrusions are more often discordant higher up in the stratigraphic succession. Local hornfels-facies metamorphism accompanied the emplacement of many of the larger sills. Major tectonic deformation that began during the Early Jurassic Epoch and continued throughout the Laramide orogeny resulted in a structurally complex folded and faulted terrane.

In the region of the Green Mountain dike, the Burke Formation is folded into a large, open, northerly plunging anticline; several faults occur parallel to the fold axis; and the dike is located on the east limb of the 


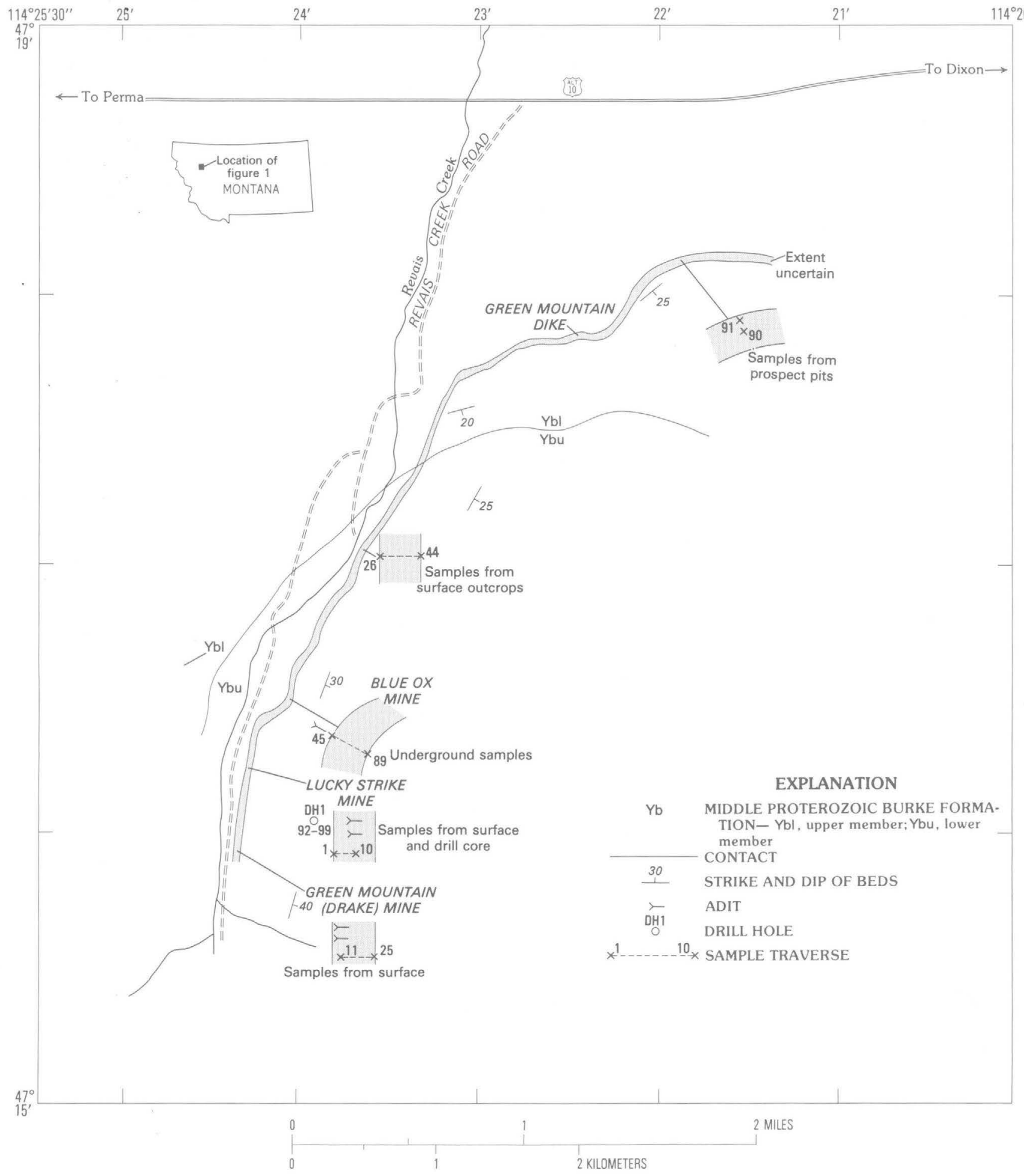

Figure 1. Sample localities and mines, and outcrop pattern of the Green Mountain dike, Sanders County, Mont. 
anticline. The Burke Formation is divided into lower and upper members. The lower member is about 3,300 ft thick (R.L. Earhart and others, unpub. data, 1980) and consists of gray-green argillites and siltites, some of which are calcareous. This member is host to low-grade stratabound copper deposits about $3 \mathrm{mi}$ west of the Green Mountain dike. The upper member is about $4,000 \mathrm{ft}$ thick (R.L. Earhart and others, unpub. data, 1980) and consists mainly of light-gray magnetite-bearing siltite, argillite, and quartzite. The northernmost outcrops of the Green Mountain dike are in the lower member of the Burke Formation; to the south the dike cuts up stratigraphic section into the upper member (fig. 1).

The dike occurs in an arcuate pattern over its $3.5 \mathrm{mi}$ of exposed length, and it is at least $335 \mathrm{ft}$ thick as measured in a cross-cutting adit (Crowley, 1963). The radiometric age of the dike has not been determined, but the dike is probably related to the other mafic dikes and sills intruded into Belt terrane during Late Proterozoic time. Three metadiorite sills in the region that are possibly related in time to the Green Mountain dike were dated by potassium-argon methods at 803,854 , and $770 \mathrm{~m}$.y. (Marvin and others, 1984).

\section{SAMPLING AND ANALYSIS}

Sampling of the Green Mountain dike was primarily designed to study the distribution of metals with respect to structures and to compositional variations within the dike. Sources of samples include outcrops, prospect pits, underground workings, and drill core. The approximate localities of the samples are shown in figure 1. Of the underground workings, only the Blue Ox mine was accessible at the time of the investigations. Samples were collected systematically at intervals from west to east across the width of the dike (fig. 1). Unless otherwise specified, all samples are single grab samples weighing from 1 to $2 \mathrm{lbs}$.

Samples 1 through 10 (channel samples), collected from exposures in an open pit near the Lucky Strike mine, represent a $27-\mathrm{ft}$ section of the lower (western) part of the dike. Eight samples (92-99) are from drill core provided by the U.S. Bureau of Mines in 1979. The inclined drill hole intersected the dike below the Lucky Strike mine (fig. 1). It was drilled at a $45^{\circ}$ angle to a depth of $350 \mathrm{ft}$. The samples are composites of 1 - to 2 -ft intervals of material that was selected because of megascopically visible copper minerals. Sample sets 11 through 25 (near the Green Mountain (Drake) mine) and 26 through 44 (about $1 \mathrm{mi}$ north of the Blue Ox mine) are samples from surface exposures spaced at large intervals across the width of the dike. Samples 45 through 89 were collected from underground workings of the Blue Ox mine. The mine adit, with a bearing perpendicular to strike of the dike, cuts the entire dike width of $340 \mathrm{ft}$. These samples were collected at $10-\mathrm{ft}$ intervals, and represent a complete subsurface cross section of the dike. Samples 57 through 62 of this set are channel samples taken from a northsouth-trending fracture zone. Ore-bearing rock from this zone (which is $150 \mathrm{ft}$ from the mine portal) was depleted by mining. Samples 90 and 91 are from small prospect pits near the northernmost exposures of the dike.

Samples were analyzed for 50 elements by a six-step semiquantitative spectrographic method (table 1). Results of this analysis are identified with respect to geometric brackets whose boundaries are $1.2,0.83,0.56,0.38,0.26$, $0.18,0.12$, etc., and are reported arbitrarily as midpoints of these brackets: $1,0.7,0.5,0.3,0.2,0.15$, and 0.1 , etc. The precision of a reported value is approximately plus or minus one bracket at 68 percent, or two brackets at 95 percent confidence.

Elements determined by this method and shown in table 1 include $\mathrm{Co}, \mathrm{Cr}, \mathrm{Cu}, \mathrm{Mo}, \mathrm{Ni}, \mathrm{Pb}$, and $\mathrm{Ag}$. Other elements determined are not included because either they have no recognizable significance, or they were below their detection limits. Palladium, platinum, and rhodium (also table 1) were determined by combined fire assay and emission spectrography (Haffty and Riley, 1968). Gold was determined by fire assay and atomic absorption spectrography.

\section{DIKE COMPOSITION}

The dike rock composition, although somewhat obscured by alteration, ranges from dioritic to gabbroic. Modal analysis of a sample of relatively unaltered hornblende diorite collected underground from the Blue $\mathrm{Ox}$ adit near the center of the dike gave the following composition: quartz 6 percent, feldspar (andesine) 28 percent, amphiboles (hornblende and cummingtonite) 42 percent, ilmenite 6 percent, diopside 2 percent, chlorite and illite 10 percent, and a trace of apatite and malachite. Olivine (fayalite), although not found in this sample, is abundant in others.

The Green Mountain dike is strongly altered both deuterically and by later hydrothermal activity along fractures. Mafic minerals are commonly altered to chlorite, which imparts a greenish tint to the dike. The host rocks (Burke Formation) adjacent to the dike are not visibly altered by contact metamorphism. 
Table 1. Analyses of intrusive rocks from the Green Mountain dike

[For sample localities see figure 1. All data in parts per million. Numbers in parentheses below elements indicate lower limits of determination. Leaders (---), element not looked for; N, not detected at limit of detection; L, detected but below limit of determination. $\mathrm{Co}, \mathrm{Cr}, \mathrm{Cu}, \mathrm{Mo}, \mathrm{Ni}$, and $\mathrm{Pb}$ by semiquantitative spectrographic analysis by $\mathrm{M} . J$. Malcolm and Nancy Conklin; $\mathrm{Pd}$, $\mathrm{Pt}$, and Rh determined by fire assay-emission spectrography by Joseph Haffty and A.W. Haubert; Au determined by fire assay-atomic adsorption spectrography by J.G. Crock, A.W. Haubert, and Joseph Haffty]

\begin{tabular}{|c|c|c|c|c|c|c|c|c|c|c|c|}
\hline $\begin{array}{l}\text { Sample } \\
\text { No. }\end{array}$ & $\begin{array}{l}\text { Co } \\
\text { (5) }\end{array}$ & $\begin{array}{l}\mathrm{Cr} \\
(1)\end{array}$ & $\begin{array}{l}\mathrm{Cu} \\
\text { (1) }\end{array}$ & $\begin{array}{l}\text { Mo } \\
\text { (3) }\end{array}$ & $\begin{array}{r}\mathrm{Ni} \\
(5)\end{array}$ & $\begin{array}{l}\mathrm{Pb} \\
(10)\end{array}$ & $\begin{array}{c}\mathrm{Pd} \\
(.004)\end{array}$ & $\begin{array}{c}\mathrm{Pt} \\
(.010)\end{array}$ & $\begin{array}{c}\mathrm{Rh} \\
(.005)\end{array}$ & $\begin{array}{c}\mathrm{Au} \\
(.05)\end{array}$ & $\begin{array}{c}\mathrm{Ag} \\
(.5)\end{array}$ \\
\hline 1 & 20 & 30 & 300 & $\mathrm{~N}$ & 70 & $\mathrm{~N}$ & 0.02 & 0.037 & $\mathrm{~N}$ & -- & $\mathrm{N}$ \\
\hline 2 & 70 & 50 & 700 & $\mathrm{~N}$ & 70 & $\mathrm{~N}$ & .024 & .028 & $\mathrm{~N}$ & -- & $\mathrm{N}$ \\
\hline 3 & 50 & 70 & 7,000 & $\mathrm{~N}$ & 300 & 50 & .66 & .99 & 0.023 & 2.9 & 1.5 \\
\hline 4 & 50 & 70 & 15,000 & $\mathrm{~N}$ & 300 & 15 & 3.2 & .80 & .062 & .73 & 3 \\
\hline 5 & 30 & 30 & 5,000 & $\mathrm{~N}$ & 70 & $\mathrm{~N}$ & .25 & .075 & $\mathrm{~N}$ & .07 & $\mathrm{~N}$ \\
\hline 6 & 70 & 70 & 3,000 & $\mathrm{~N}$ & 150 & $\mathrm{~N}$ & .11 & .056 & $\mathrm{~N}$ & .06 & $\mathrm{~N}$ \\
\hline 7 & 70 & 70 & 1,500 & $\mathrm{~N}$ & 100 & $\mathrm{~N}$ & .084 & .067 & $\mathrm{~N}$ & $\mathrm{~N}$ & $\mathrm{~N}$ \\
\hline 8 & 70 & 70 & 5,000 & $\mathrm{~N}$ & 100 & $\mathrm{~N}$ & .075 & .043 & $\mathrm{~N}$ & $\mathrm{~N}$ & $\mathrm{~N}$ \\
\hline 9 & 100 & 100 & 10,000 & $\mathrm{~N}$ & 500 & $\mathrm{~N}$ & 1.8 & .70 & .026 & .64 & 1.5 \\
\hline 10 & 3 & 30 & 150 & $\mathrm{~N}$ & 10 & 20 & - & - & -- & -- & $\mathrm{N}$ \\
\hline 11 & 70 & 50 & 10,000 & 30 & 200 & $\mathrm{~N}$ & .99 & .75 & .018 & .30 & $\mathrm{~N}$ \\
\hline 12 & 70 & 70 & 15,000 & 30 & 200 & $\mathrm{~N}$ & .79 & 1.00 & .035 & .28 & $\mathrm{~N}$ \\
\hline 13 & 100 & 20 & 2,000 & $\mathrm{~N}$ & 200 & 100 & .026 & .024 & $\mathrm{~N}$ & $\mathrm{~N}$ & $\mathrm{~N}$ \\
\hline 14 & 70 & 1 & 300 & $\mathrm{~N}$ & 20 & $\mathrm{~N}$ & .009 & $\mathrm{~N}$ & $\mathrm{~N}$ & $\mathrm{~N}$ & $\mathrm{~N}$ \\
\hline 15 & 70 & 70 & 500 & $\mathrm{~N}$ & 100 & 20 & .013 & .029 & $\mathrm{~N}$ & $\mathrm{~N}$ & $\mathrm{~N}$ \\
\hline 16 & 70 & 70 & 300 & $\mathrm{~N}$ & 100 & $\mathrm{~N}$ & .023 & .033 & $\mathrm{~N}$ & $\mathrm{~N}$ & $\mathrm{~N}$ \\
\hline 17 & 70 & 70 & 300 & $\mathrm{~N}$ & 100 & $\mathrm{~N}$ & .012 & .026 & $\mathrm{~N}$ & $\mathrm{~N}$ & $\mathrm{~N}$ \\
\hline 18 & 50 & 70 & 300 & $\mathrm{~N}$ & 100 & $\mathrm{~N}$ & .026 & .040 & $\mathrm{~N}$ & $\mathrm{~N}$ & $\mathrm{~N}$ \\
\hline 19 & 70 & 70 & 300 & $\mathrm{~N}$ & 100 & $\mathrm{~N}$ & .010 & .027 & $\mathrm{~N}$ & $\mathrm{~N}$ & $\mathrm{~N}$ \\
\hline 20 & 50 & 70 & 300 & $\mathrm{~N}$ & 100 & $\mathrm{~L}$ & .013 & .020 & $\mathrm{~N}$ & $\mathrm{~N}$ & $N$ \\
\hline 21 & 70 & 70 & 300 & $\mathrm{~N}$ & 100 & L & .009 & .016 & $\mathrm{~N}$ & $\mathrm{~N}$ & $\mathrm{~N}$ \\
\hline 22 & 70 & 70 & 200 & $\mathrm{~N}$ & 70 & $\mathrm{~N}$ & .045 & .040 & $\mathrm{~N}$ & $\mathrm{~N}$ & $\mathrm{~N}$ \\
\hline 23 & 70 & 70 & 300 & $\mathrm{~N}$ & 70 & $\mathrm{~N}$ & .033 & .039 & $\mathrm{~N}$ & $\mathrm{~N}$ & $\mathrm{~N}$ \\
\hline 24 & 50 & 70 & 300 & $\mathrm{~N}$ & 70 & $\mathrm{~N}$ & .009 & .027 & $\mathrm{~N}$ & $\mathrm{~N}$ & $\mathrm{~N}$ \\
\hline 25 & 50 & 70 & 300 & $\mathrm{~N}$ & 70 & $\mathrm{~N}$ & .027 & .019 & $\mathrm{~N}$ & $\mathrm{~N}$ & $\mathrm{~N}$ \\
\hline 26 & 70 & 70 & 300 & $\mathrm{~N}$ & 70 & $\mathrm{~N}$ & .011 & .025 & $\mathrm{~N}$ & $\mathrm{~N}$ & $\mathrm{~N}$ \\
\hline 27 & 70 & 70 & 300 & $\mathrm{~N}$ & 150 & $\mathrm{~N}$ & .007 & .029 & $\mathrm{~N}$ & $\mathrm{~N}$ & $\mathrm{~N}$ \\
\hline 28 & 30 & 70 & 200 & $\mathrm{~N}$ & 70 & L & .009 & .020 & $\mathrm{~N}$ & $\mathrm{~N}$ & $\mathrm{~N}$ \\
\hline 29 & 70 & 70 & 300 & $\mathrm{~N}$ & 150 & 10 & .040 & .028 & $\mathrm{~N}$ & $\mathrm{~N}$ & $\mathrm{~N}$ \\
\hline 30 & 30 & 50 & 300 & $\mathrm{~N}$ & 70 & L & .008 & .010 & $\mathrm{~N}$ & $\mathrm{~N}$ & $\mathrm{~N}$ \\
\hline 31 & 70 & 70 & 200 & $N$ & 70 & $\mathrm{~N}$ & .008 & .027 & $\mathrm{~N}$ & $\mathrm{~N}$ & $\mathrm{~N}$ \\
\hline 32 & 50 & 70 & 200 & $\mathrm{~N}$ & 70 & $\mathrm{~N}$ & .016 & .023 & $\mathrm{~N}$ & $\mathrm{~N}$ & $\mathrm{~N}$ \\
\hline 33 & 30 & 30 & 150 & $\mathrm{~N}$ & 50 & $\mathrm{~N}$ & .018 & .040 & $\mathrm{~N}$ & $\mathrm{~N}$ & $\mathrm{~N}$ \\
\hline 34 & 20 & 30 & 200 & $\mathrm{~N}$ & 30 & $\mathrm{~N}$ & .052 & .043 & $\mathrm{~N}$ & $\mathrm{~N}$ & $\mathrm{~N}$ \\
\hline 35 & 20 & 30 & 300 & $\mathrm{~N}$ & 30 & $\mathrm{~L}$ & .040 & .074 & $\mathrm{~N}$ & $N$ & $\mathrm{~N}$ \\
\hline 36 & 70 & 70 & 200 & $\mathrm{~N}$ & 70 & $\mathrm{~N}$ & .035 & .068 & $\mathrm{~N}$ & $\mathrm{~N}$ & $\mathrm{~N}$ \\
\hline 37 & 30 & 30 & 300 & $\mathrm{~N}$ & 30 & $\mathrm{~N}$ & .035 & .062 & $\mathrm{~N}$ & $\mathrm{~N}$ & $\mathrm{~N}$ \\
\hline 38 & 20 & 30 & 300 & $\mathrm{~N}$ & 30 & $\mathrm{~N}$ & .031 & .053 & $\mathrm{~N}$ & $\mathrm{~N}$ & $\mathrm{~N}$ \\
\hline 39 & 70 & 30 & 500 & $\mathrm{~N}$ & 70 & $\mathrm{~N}$ & .011 & .031 & $\mathrm{~N}$ & $\mathrm{~N}$ & $\mathrm{~N}$ \\
\hline 40 & 70 & 70 & 300 & $\mathrm{~N}$ & 70 & $\mathrm{~N}$ & .010 & .021 & $\mathrm{~N}$ & $\mathrm{~N}$ & $\mathrm{~N}$ \\
\hline 41 & 15 & 15 & 300 & $\mathrm{~N}$ & 20 & $\mathrm{~N}$ & .019 & .021 & $\mathrm{~N}$ & $\mathrm{~N}$ & $\mathrm{~N}$ \\
\hline 42 & 15 & 30 & 150 & $\mathrm{~N}$ & 30 & $\mathrm{~N}$ & .012 & .034 & $\mathrm{~N}$ & $\mathrm{~N}$ & $\mathrm{~N}$ \\
\hline 43 & 70 & 30 & 300 & $\mathrm{~N}$ & 70 & $\mathrm{~N}$ & .012 & .026 & $\mathrm{~N}$ & $\mathrm{~N}$ & $\mathrm{~N}$ \\
\hline 44 & 7 & 30 & 20 & $\mathrm{~N}$ & 15 & 10 & $\mathrm{~N}$ & $\mathrm{~N}$ & $\mathrm{~N}$ & $\mathrm{~N}$ & $\mathrm{~N}$ \\
\hline 45 & $\mathrm{~L}$ & 50 & 70 & 7 & 5 & $\mathrm{~N}$ & .008 & $\mathrm{~N}$ & $\mathrm{~N}$ & $\mathrm{~N}$ & $\mathrm{~N}$ \\
\hline 46 & 20 & 70 & 200 & $\mathrm{~N}$ & 20 & 15 & .009 & $\mathrm{~N}$ & $\mathrm{~N}$ & $\mathrm{~N}$ & $\mathrm{~N}$ \\
\hline 47 & 15 & 50 & 50 & $\mathrm{~N}$ & 20 & 50 & .005 & $\mathrm{~N}$ & $\mathrm{~N}$ & $\mathrm{~N}$ & $\mathrm{~N}$ \\
\hline 48 & L & 20 & 70 & $\mathrm{~N}$ & L & $\mathrm{N}$ & .009 & $\mathrm{~N}$ & $\mathrm{~N}$ & $\mathrm{~N}$ & $\mathrm{~N}$ \\
\hline 49 & 50 & 70 & 300 & $\mathrm{~N}$ & 100 & $\mathrm{~N}$ & .018 & .010 & $\mathrm{~N}$ & $\mathrm{~N}$ & $\mathrm{~N}$ \\
\hline 50 & 70 & 50 & 300 & $\mathrm{~N}$ & 70 & $\mathrm{~N}$ & .017 & .028 & $\mathrm{~N}$ & $\mathrm{~N}$ & $\mathrm{~N}$ \\
\hline
\end{tabular}

${ }^{\mathrm{l}}$ Silver determined by fire assay-atomic adsorption. 
Table 1. Analyses of intrusive rocks-Continued

\begin{tabular}{|c|c|c|c|c|c|c|c|c|c|c|c|}
\hline $\begin{array}{l}\text { Sample } \\
\text { No. }\end{array}$ & $\begin{array}{l}\text { Co } \\
\text { (5) }\end{array}$ & $\begin{array}{l}\mathrm{Cr} \\
\text { (1) }\end{array}$ & $\begin{array}{l}\mathrm{Cu} \\
\text { (1) }\end{array}$ & $\begin{array}{l}\text { Mo } \\
\text { (3) }\end{array}$ & $\begin{array}{r}\mathrm{Ni} \\
(5)\end{array}$ & $\begin{array}{c}\mathrm{Pb} \\
(10)\end{array}$ & $\begin{array}{c}\mathrm{Pd} \\
(.004)\end{array}$ & $\begin{array}{c}\mathrm{Pt} \\
(.010)\end{array}$ & $\begin{array}{c}\mathrm{Rh} \\
(.005)\end{array}$ & $\begin{array}{c}\mathrm{Au} \\
(.05)\end{array}$ & $\begin{array}{c}\mathrm{Ag} \\
(.5)\end{array}$ \\
\hline 51 & 50 & 50 & 200 & $\mathrm{~N}$ & 70 & $\mathrm{~N}$ & 0.022 & 0.029 & $\mathrm{~N}$ & $\mathrm{~N}$ & $\mathrm{~N}$ \\
\hline 52 & 50 & 70 & 200 & $\mathrm{~N}$ & 70 & $\mathrm{~N}$ & .033 & .024 & $\mathrm{~N}$ & $\mathrm{~N}$ & $\mathrm{~N}$ \\
\hline 53 & 70 & 70 & 700 & $\mathrm{~N}$ & 70 & $\mathrm{~N}$ & .024 & .038 & $\mathrm{~N}$ & $\mathrm{~N}$ & $\mathrm{~N}$ \\
\hline 54 & 50 & 70 & 300 & $\mathrm{~N}$ & 70 & $\mathrm{~N}$ & .006 & .010 & $\mathrm{~N}$ & $\mathrm{~N}$ & $\mathrm{~N}$ \\
\hline 55 & 50 & 50 & 300 & $\mathrm{~N}$ & 70 & $\mathrm{~N}$ & .006 & $\mathrm{~N}$ & $\mathrm{~N}$ & $N$ & $N$ \\
\hline 56 & 50 & 70 & 500 & $\mathrm{~N}$ & 70 & $\mathrm{~N}$ & .029 & .028 & $\mathrm{~N}$ & $\mathrm{~N}$ & $\mathrm{~N}$ \\
\hline 57 & 70 & 70 & 30,000 & 30 & 700 & $\mathrm{~N}$ & 2.9 & 1.2 & .039 & .55 & 2 \\
\hline 58 & 70 & 150 & 15,000 & $\mathrm{~N}$ & 200 & $\mathrm{~N}$ & 2.2 & .91 & .021 & -- & 7 \\
\hline 59 & 30 & 100 & 7,000 & $\mathrm{~N}$ & 150 & $\mathrm{~N}$ & 1.6 & .34 & $\mathrm{~N}$ & -- & 5 \\
\hline 60 & 30 & 150 & 2,000 & $N$ & 100 & $\mathrm{~N}$ & .27 & .13 & $N$ & -- & 1 \\
\hline 61 & 30 & 70 & 2,000 & $\mathrm{~N}$ & 100 & $\mathrm{~N}$ & .24 & .11 & $\mathrm{~N}$ & -- & 1 \\
\hline 62 & 30 & 70 & 1,500 & $\mathrm{~N}$ & 70 & $\mathrm{~N}$ & .34 & .053 & $\mathrm{~N}$ & -- & .7 \\
\hline 63 & 50 & 50 & 300 & $\mathrm{~N}$ & 70 & $\mathrm{~N}$ & .026 & .038 & $\mathrm{~N}$ & $\mathrm{~N}$ & $\mathrm{~N}$ \\
\hline 64 & 50 & 70 & 300 & $\mathrm{~N}$ & 70 & $\mathrm{~N}$ & .018 & .025 & $\mathrm{~N}$ & $\mathrm{~N}$ & $\mathrm{~N}$ \\
\hline 65 & 50 & 50 & 300 & $\mathrm{~N}$ & 50 & $\mathrm{~N}$ & .024 & .034 & $\mathrm{~N}$ & $\mathrm{~N}$ & $\mathrm{~N}$ \\
\hline 66 & 50 & 50 & 500 & $\mathrm{~N}$ & 70 & $\mathrm{~N}$ & .029 & .033 & $\mathrm{~N}$ & $\mathrm{~N}$ & $\mathrm{~N}$ \\
\hline 67 & 50 & 50 & 500 & $\mathrm{~N}$ & 70 & $\mathrm{~N}$ & .066 & .050 & $\mathrm{~N}$ & $\mathrm{~N}$ & $\mathrm{~N}$ \\
\hline 68 & 50 & 50 & 500 & $\mathrm{~N}$ & 70 & $\mathrm{~N}$ & .063 & .053 & $\mathrm{~N}$ & $\mathrm{~N}$ & $\mathrm{~N}$ \\
\hline 69 & 50 & 70 & 500 & $\mathrm{~N}$ & 70 & $\mathrm{~N}$ & .055 & .052 & $\mathrm{~N}$ & $\mathrm{~N}$ & $\mathrm{~N}$ \\
\hline 70 & 70 & 50 & 500 & $N$ & 70 & $\mathrm{~N}$ & .036 & .056 & $\mathrm{~N}$ & $\mathrm{~N}$ & $\mathrm{~N}$ \\
\hline 71 & 70 & 50 & 1,000 & $\mathrm{~N}$ & 70 & $\mathrm{~N}$ & .13 & .078 & $\mathrm{~N}$ & $\mathrm{~N}$ & $\mathrm{~N}$ \\
\hline 72 & 70 & 70 & 1,000 & $\mathrm{~N}$ & 100 & $\mathrm{~N}$ & .12 & .087 & $\mathrm{~N}$ & $\mathrm{~N}$ & $\mathrm{~N}$ \\
\hline 73 & 30 & 70 & 1,000 & $\mathrm{~N}$ & 50 & $\mathrm{~N}$ & .089 & .057 & $\mathrm{~N}$ & $\mathrm{~N}$ & 1 \\
\hline 74 & 50 & 50 & 1,000 & $\mathrm{~N}$ & 100 & $\mathrm{~N}$ & .15 & .093 & $\mathrm{~N}$ & $N$ & $\mathrm{~N}$ \\
\hline 75 & 70 & 50 & 1,000 & $\mathrm{~N}$ & 100 & $\mathrm{~N}$ & .057 & .067 & $\mathrm{~N}$ & $\mathrm{~N}$ & $\mathrm{~N}$ \\
\hline 76 & 70 & 30 & 500 & $\mathrm{~N}$ & 70 & $\mathrm{~N}$ & .049 & .062 & $\mathrm{~N}$ & $\mathrm{~N}$ & $\mathrm{~N}$ \\
\hline 77 & 50 & 30 & 500 & $\mathrm{~N}$ & 70 & $\mathrm{~N}$ & .044 & .044 & $\mathrm{~N}$ & $\mathrm{~N}$ & $\mathrm{~N}$ \\
\hline 78 & 70 & 50 & 700 & $\mathrm{~N}$ & 100 & $\mathrm{~N}$ & .069 & .062 & $\mathrm{~N}$ & $\mathrm{~N}$ & $\mathrm{~N}$ \\
\hline 79 & 70 & 30 & 2,000 & $\mathrm{~N}$ & 100 & $\mathrm{~N}$ & .15 & .077 & $\mathrm{~N}$ & .12 & 63 \\
\hline 80 & 70 & 50 & 2,000 & $\mathrm{~N}$ & 100 & $\mathrm{~N}$ & .16 & .073 & $\mathrm{~N}$ & $\mathrm{~N}$ & $\mathrm{~N}$ \\
\hline 81 & 50 & 15 & 300 & $\mathrm{~N}$ & 50 & $\mathrm{~N}$ & .021 & .024 & $\mathrm{~N}$ & $\mathrm{~N}$ & $\mathrm{~N}$ \\
\hline 82 & 70 & 20 & 2,000 & $\mathrm{~N}$ & 70 & $\mathrm{~N}$ & .094 & .095 & $\mathrm{~N}$ & $\mathrm{~N}$ & $\mathrm{~N}$ \\
\hline 83 & 50 & 20 & 500 & $\mathrm{~N}$ & 70 & $\mathrm{~N}$ & .042 & .036 & $\mathrm{~N}$ & $\mathrm{~N}$ & $\mathrm{~N}$ \\
\hline 84 & 50 & 20 & 500 & $\mathrm{~N}$ & 50 & $\mathrm{~N}$ & .021 & .031 & $\mathrm{~N}$ & $\mathrm{~N}$ & $\mathrm{~N}$ \\
\hline 85 & 50 & 50 & 200 & $\mathrm{~N}$ & 70 & $\mathrm{~N}$ & .037 & .049 & $\mathrm{~N}$ & $\mathrm{~N}$ & $\mathrm{~N}$ \\
\hline 86 & 50 & 30 & 500 & $\mathrm{~N}$ & 70 & $\mathrm{~N}$ & .090 & .084 & $\mathrm{~N}$ & $\mathrm{~N}$ & $\mathrm{~N}$ \\
\hline 87 & 30 & 70 & 150 & $\mathrm{~N}$ & 50 & $\mathrm{~N}$ & .024 & .021 & $\mathrm{~N}$ & $\mathrm{~N}$ & $\mathrm{~N}$ \\
\hline 88 & 5 & 30 & 20 & $\mathrm{~N}$ & 15 & $\mathrm{~N}$ & .008 & $\mathrm{~N}$ & $\mathrm{~N}$ & $\mathrm{~N}$ & $\mathrm{~N}$ \\
\hline 89 & 30 & 30 & 500 & $\mathrm{~N}$ & 50 & $\mathrm{~N}$ & .023 & .027 & $\mathrm{~N}$ & $\mathrm{~N}$ & $\mathrm{~N}$ \\
\hline 90 & 30 & 20 & 700 & $\mathrm{~N}$ & 50 & $\mathrm{~L}$ & .026 & .043 & $\mathrm{~N}$ & $\mathrm{~N}$ & $\mathrm{~N}$ \\
\hline 91 & 50 & 50 & 20,000 & $\mathrm{~N}$ & 300 & $\mathrm{~L}$ & 1.7 & .81 & .018 & .67 & 11.5 \\
\hline 92 & 30 & 50 & 700 & $\mathrm{~N}$ & 70 & $\mathrm{~N}$ & .062 & .032 & $\mathrm{~N}$ & $\mathrm{~N}$ & $\mathrm{~N}$ \\
\hline 93 & 20 & 50 & 300 & $\mathrm{~N}$ & 20 & $\mathrm{~N}$ & .016 & .02 & $\mathrm{~N}$ & $\mathrm{~N}$ & $\mathrm{~N}$ \\
\hline 94 & 50 & 100 & 3,000 & $\mathrm{~N}$ & 150 & $\mathrm{~N}$ & .57 & .19 & $\mathrm{~N}$ & .12 & L \\
\hline 95 & 70 & 20 & 30,000 & $\mathrm{~N}$ & 300 & $\mathrm{~N}$ & 1.0 & .86 & .11 & .15 & 3 \\
\hline 96 & 30 & 50 & 2,000 & $\mathrm{~N}$ & 50 & $\mathrm{~N}$ & .20 & .084 & $\mathrm{~N}$ & .07 & $\mathrm{~N}$ \\
\hline 97 & 30 & 70 & 3,000 & $\mathrm{~N}$ & 100 & 150 & .12 & .046 & $\mathrm{~N}$ & $\mathrm{~N}$ & 1 \\
\hline 98 & 15 & 30 & 2,000 & $\mathrm{~N}$ & 30 & $\mathrm{~N}$ & .46 & .18 & $\mathrm{~N}$ & .13 & $\mathrm{~N}$ \\
\hline 99 & 15 & 50 & 1,000 & $\mathrm{~N}$ & 70 & $\mathrm{~N}$ & .10 & .08 & $\mathrm{~N}$ & $\mathrm{~N}$ & $\mathrm{~N}$ \\
\hline
\end{tabular}




\section{MINERALIZATION}

Mineralization within the dike was apparently confined to fractures, fissures and breccia zones, which provided the conduits for movement of hydrothermal fluids. These faults and shear zones, as well as altered rock adjacent to these structures, are enriched in platinum, palladium, copper, gold, silver, and nickel. Through the effects of weathering and hydrothermal activity, $\mathrm{Pd}, \mathrm{Pt}$, and probably $\mathrm{Cu}$ have been remobilized from the mafic dike rocks and concentrated in fractures. The dike has been broken and shattered by cross-cutting faults and shear zones, and by movement along the dikehost rock contact. Most fractured rock contains copper minerals.

The most important ore production was from a deposit along the lower contact of the dike at the Green Mountain (Drake) mine (Crowley, 1963). The ore there was mined from fractures, quartz veins, and altered rock, with the richest ore in an oxide zone that consisted primarily of hematite and clay. The orebody is zoned vertically, according to 1976 unpublished data by the U.S. Geological Survey and the U.S. Bureau of Mines (on the status of mineral resource information for the Flathead Indian Reservation), which stated: "The enriched zone is made up of both an oxide zone and a zone of secondary chalcocite. The oxide zone continues from the surface to a depth of about $80 \mathrm{ft}$ and contains malachite, chrysocolla, cuprite, and tenorite. The oxide zone is underlain by the secondary chalcocite zone which is about $30 \mathrm{ft}$ thick. The enriched zone grades into a zone of primary mineralization containing chalcopyrite, chalcocite, and bornite. An appreciable amount of silver, gold, and platinum-palladium was recovered from both oxide and sulfide ores."

The principal copper sulfide in samples collected for this report is chalcopyrite, which occurs in variable amounts and ranges from massive in fractures to fine disseminations in wall rocks. Other associated copper minerals include chalcocite, bornite, and secondary malachite. Pyrite and pyrrhotite closely associated with the enriched rock are partly oxidized to goethite.

\section{METAL DISTRIBUTION}

Histograms that plot element concentrations against numbers of samples were constructed for copper and the sum of the platinum-group metals $(\mathrm{Pt}+\mathrm{Pd}+\mathrm{Rh})$ (fig. 2). The threshold concentration values, indicated by arrows on the histograms, were chosen by plotting the cumulative percent frequency distributions as described by Sinclair (1974). The threshold, the concentration value at which a rock is considered anomalous, was chosen at $1,000 \mathrm{ppm}$ for copper and $0.1 \mathrm{ppm}$ for the platinumgroup metals. Using these somewhat arbitrary threshold values, 28 percent of all samples are enriched in both copper and the platinum-group metals, 13 percent are enriched in only the platinum-group elements and only one sample contains anomalous copper without enrichment of the platinum-group. These results clearly illustrate a close geochemical association of copper and platinumgroup metals. Considering platinum and palladium separately, each with a threshold of $0.1 \mathrm{ppm}$, palladium is enriched in 25 percent of the samples, whereas platinum is enriched in only 15 percent.

McCallum and others (1976), in a study of Pt-Pd$\mathrm{Cu}$ ores of the New Rambler mine (Wyoming), stated that the most significant evidence for a strictly hydrothermal origin is the predominance of the more readily soluble platinum-group elements $\mathrm{Pd}$ and $\mathrm{Pt}$ (Pd being most mobile), and a relative lack of the more inert platinumgroup elements Ir, Os, $\mathrm{Ru}$, and $\mathrm{Rh}$. Ores from shear zones in metagabbroic rocks at the New Rambler mine have a Pd:Pt ratio of $18: 1$ and a $\mathrm{Pd}: \mathrm{Pt}: \mathrm{Ir}+\mathrm{Ru}+\mathrm{Os}$ (minor platinum-group elements) of nearly 1800:100:1 (McCallum and others, 1976). The distribution of platinum-group elements in the Green Mountain dike follows similar patterns, even though concentrations of the metals in the dike are much lower. The Pd:Pt ratio for samples of enriched rock averages 2:1 with one value of 6:1. Samples of unaltered gabbroic and dioritic dike rocks have a $\mathrm{Pd}: \mathrm{Pt}$ ratio which averages $0.8: 1$. The average $\mathrm{Pd}: \mathrm{Pt}: \mathrm{Rh}$ ratio for enriched rock is 60:30:1.

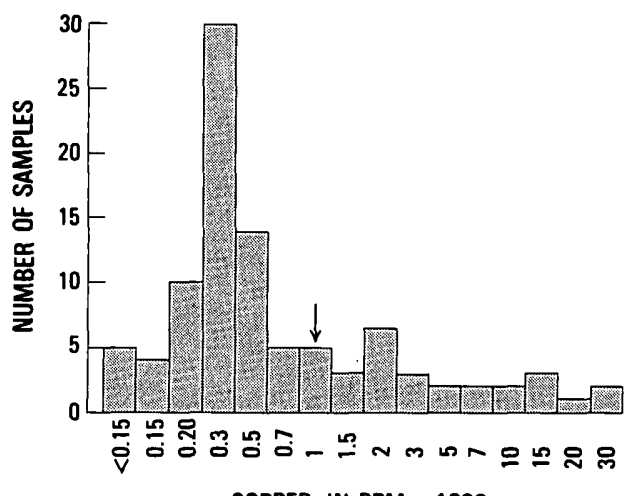

COPPER, IN PPM $\times 1000$

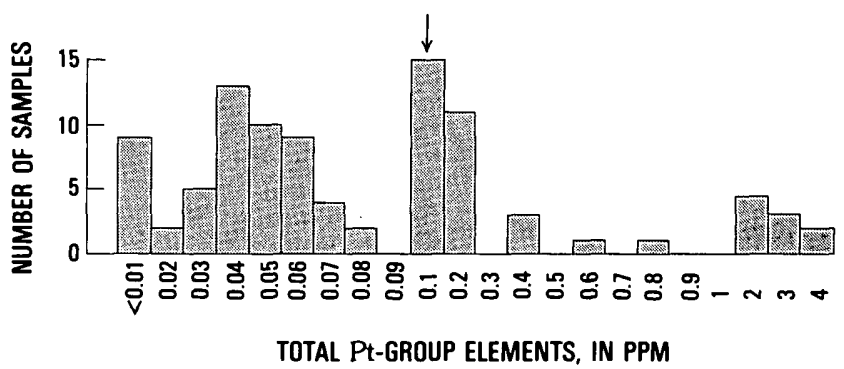

Figure 2. Histograms showing number of samples at various concentrations of metals. Arrow indicates threshold value. Samples with metal content at arrow and above are considered anomalous (enriched) 
These ratios, although not as high as those of the New Rambler mine, are inferred to reflect migration and concentration of the more soluble platinum-group metals by hydrothermal fluids.

Three samples with relatively high concentrations of Pd and Pt (Nos. 11, 12 and 57) were further analyzed for iridium and ruthenium; however, neither one was detected at the respective lower limits of detection of these elements $(0.03 \mathrm{ppm}$ and $0.1 \mathrm{ppm})$.

Chromium and cobalt are present in very low amounts (trace to $100 \mathrm{ppm}$ ) and show no correlation or increased concentrations in the platinum-palladiumenriched rock.

Nickel, although present in very small amounts, can be correlated with enriched rock. Values ranged from $10 \mathrm{ppm}$ in unaltered rock to $700 \mathrm{ppm}$ in enriched rock.

Gold and silver show a similar association to enriched rock in that none was detected in unaltered rock.

Lead and zinc do not appear to be associated with precious-metal mineralization. Zinc did not exceed the detection limit of the method (200 and $500 \mathrm{ppm}-\mathrm{a}$ higher detection limit was required by some samples) in any of the samples. Samples $92-99$ included from 100 to $200 \mathrm{ppm}$ zinc (determined by atomic absorption methods).

Ten samples contained detectable lead that ranged from $<10 \mathrm{ppm}$ to $100 \mathrm{ppm}$, but these samples apparently were not enriched in platinum-group metals. Only a few pounds of lead reportedly were shipped from the district during mining operations (Crowley, 1963).

\section{NATURE OF PLATINUM IN DIKE}

Several polished sections of dike rock that contained the highest amounts of platinum were examined microscopically. The highly reflective grains were further analyzed using an electron microprobe in attempts to identify platinum minerals. A single grain of sperrylite $\left(\mathrm{PtAs}_{2}\right)$ was found in sample 91. The sample was collected from a small prospect pit near the north end of the dike (see fig. 1). The sperrylite grain is pear-shaped, about $0.004 \mathrm{~mm}$ by $0.002 \mathrm{~mm}$, and occurs in fractured gabbro that contains 2 percent copper as disseminated chalcopyrite. Heavy concentrates, separated from several metal-enriched samples, were analyzed with the electron microprobe; however, no platinum minerals were found.

This paucity of microscopically visible platinumgroup minerals suggests that at least some of these elements may be incorporated in the lattice of other minerals.

\section{SUMMARY}

The distribution of platinum-group metals and associated copper-gold-silver minerals in the Green Mountain dike is controlled by faults and shear zones that cut across the dike or parallel the dike contacts. These faults and shear zones, as well as altered rock adjacent to these structures, are enriched in platinum, palladium, copper, gold, silver, and nickel. Through the effects of weathering and hydrothermal activity, $\mathrm{Pd}, \mathrm{Pt}$, and probably $\mathrm{Cu}$ have been remobilized from the mafic dike rocks and concentrated in fractures. Anomalous rocks, defined as those containing 1,000 ppm or more copper, are enriched in both Pd and Pt. Furthermore, Pd, the most mobile of the Pt-group elements, is enriched over Pt by a factor of 2:1. Unaltered dike rocks contain slightly more platinum than palladium.

Analytical results of samples collected across the dike indicate a lack of metal association with any layered compositional differentiate that might be present in the dike. Trace amounts of the same metals found in fractured zones are apparently evenly distributed throughout unfractured dike rock.

\section{REFERENCES CITED}

Crowley, F.A., 1963, Mines and mineral deposits (except fuels), Sanders County, Montana: Montana Bureau of Mines and Geology Bulletin 34, p. 37.

Haffty, Joseph, and Riley, L.B., 1968, Determination of palladium, platinum and rhodium in geologic materials by fire assay and emission spectrography: Talanta, v. 15, p. 111-117.

Marvin, R.F., Zartman, R.E., Obradovich, J.D., and Harrison, J.E., 1984, Geochronometric and lead isotope data on samples from the Wallace $1^{\circ} \times 2^{\circ}$ quadrangle, Montana and Idaho: U.S. Geological Survey Map MF-1354-G, scale $1: 250,000$.

McCallum, M.E., Loucks, R.R., Carlson, R.R., Cooley, E.F., and Doerge, T.A., 1976, Platinum metals associated with hydrothermal copper ores of the New Rambler mine, Medicine Bow Mountains, Wyoming: Economic Geology, v. 71 , no. 7 , p. 1443 .

Sinclair, A.J., 1974, Selection of threshold values in geochemical data using probability graphs: Journal of Geochemical Exploration, v. 3 , no. 2 , p. $129-149$. 
Chapter H

\section{Metalliferous Oil Shale in the Upper Devonian Gibellini Facies of the Woodruff Formation, Southern Fish Creek Range, Nevada}

By GEORGE A. DESBOROUGH, FORREST G. POOLE, RICHARD K. HOSE, and GREGORY N. GREEN

The Upper Devonian Gibellini facies of the Woodruff Formation consists of marine oil shale that contains anomalous amounts of vanadium, zinc, selenium, molybdenum, and nickel

U.S. GEOLOGICAL SURVEY BULLETIN 1694

CONTRIBUTIONS TO MINERAL RESOURCES RESEARCH, 1984 


\title{
CONTENTS
}

\author{
Abstract 93 \\ Introduction 93 \\ Acknowledgments 94 \\ Methods of study 94 \\ Stratigraphic and tectonic relations $\mathbf{9 8}$ \\ Rock constituents 98 \\ Organic constituents and fossils $\mathbf{9 8}$ \\ Distribution and concentration of metals $\mathbf{1 0 2}$ \\ Conclusions 103 \\ References cited 104
}

\section{FIGURES}

1. Map locating Gibellini and Bisoni properties and Bisoni-McKay property, Nevada 94

2. Geologic map and block diagram of the Gibellini and Bisoni properties, southern Eureka County, Nevada 96

3. Photomicrographs of samples, showing texture and fabric of organic fragments, opaline silica, and sulfides $\mathbf{1 0 0}$

\section{TABLES}

1. Concentration of selected elements for composite samples from drill holes, Gibellini vanadium property 95

2. Oil yield and bulk mineralogy for composite samples from drill holes, Gibellini vanadium property 99

3. Concentration of vanadium, zinc, selenium, molybdenum, and silver in composite samples from drill holes, Gibellini and Bisoni-McKay properties 


\title{
Metalliferous Oil Shale in the Upper Devonian Gibellini Facies of the Woodruff Formation, Southern Fish Creek Range, Nevada
}

\author{
By George A. Desborough, Forrest G. Poole, Richard K. Hose,' and Gregory N. Green
}

\begin{abstract}
The Gibellini facies of the Woodruff Formation is a kerogen-rich marine sequence, as much as $60 \mathrm{~m}$ thick, of Upper Devonian siliceous mudstone, siltstone, and chert. It has been evaluated in two areas in Nevada for its potential resources of vanadium, zinc, selenium, molybdenum, and syncrude oil. In one of the areas studied, an exotic block $\left(>1.0 \times 10^{6} \mathrm{~m}^{3}\right)$ contains strongly deformed allochthonous eugeosynclinal Devonian siliceous rocks of the Gibellini facies structurally overlying deformed allochthonous eugeosynclinallike Early Mississippian siliceous rocks (Bisoni facies of the Webb Formation). Both siliceous facies within this exotic block structurally overlie less deformed autochthonous Mississippian Antelope Range Formation (lower part) and are overlapped locally by autochthonous Mississippian conglomerates of the upper Antelope Range Formation.
\end{abstract}

The Gibellini facies in both study areas contains disseminated grains and framboids of pyrite which may be primary (early diagenetic), but pyrite and marcasite in chalcedonic quartz veinlets appear to have formed during later diagenesis. Organic matter in the Gibellini facies consists mainly of amorphous, flaky and stringy sapropel. Recognizable organic remnants include radiolarian tests, sponge spicules, conodonts, brachiopod shells, algae, and humic debris.

Most fresh black rock of the Gibellini facies is low-grade oil shale. Black solid bitumen and liquid oil commonly fill voids and microfractures. Gas chromatographic analysis of the saturated hydrocarbon fraction indicates a complex mixture dominated by branched and cyclic compounds. Conodont and palynomorph color alteration, vitrinite reflectance, and RockEval pyrolysis data suggest that the organic matter in the rock is thermally immature and has not been subjected to temperatures greater than $60^{\circ} \mathrm{C}$ since deposition in Devonian time. All these characteristics are consistent with the interpretation of a low-temperature and a shallow-burial history for the Gibellini facies on ridge 7129 in the Cockalorum Wash 15-minute quadrangle, southern Fish Creek Range, Eureka County, Nevada.

Vanadium in fresh black rocks of the Gibellini facies obtained from drill holes and fresh exposures in trenches and

\footnotetext{
'ARCO Exploration Company, Box 5540, Denver, CO 80217
}

roadcuts occurs chiefly in organic matter. Metahewettite is the principal vanadium mineral in the oxidized zone, but it also occurs sparsely as red and pink nodules and fillings of microfractures in unweathered strata. High concentrations of vanadium occur in unoxidized subsurface samples and in oxidized and bleached rock that is prevalent at the surface. An observed tendency toward enrichment is due to surficial weathering and ground-water movement. Zinc which occurs as sphalerite is in high concentrations in unoxidized rock, but is depleted in oxidized rock due to leaching and weathering. Selenium occurs in organic matter. Concentrations of selenium in unoxidized rock are low, whereas in oxidized and leached rock they are enriched by oxidation. Molybdenum occurs principally in organic matter, but molybdenite is present. Concentrations of molybdenum are higher in unoxidized rock than in oxidized rock, indicating depletion upon weathering. Nickel concentrations are high in unoxidized strata but are low in the oxidized zone.

\section{INTRODUCTION}

The particular objective of this study was to determine the concentration and residence of certain metals relative to organic and inorganic components of a lowtemperature shale and chert sequence in central Nevada.

Many Paleozoic dark-colored marine mudstones and siltstones (black shales) contain significant syngenetic-early diagenetic metal concentrations as well as sufficient syncrude oil to qualify as oil shales. In addition, they commonly host epigenetic metal deposits, and serve as significant source rocks for petroleum. As black shales commonly form several-meter-thick laterally persistent units, they potentially could serve as vast low-grade metal resources. Additionally, the rock masses are either low-grade oil shales or have already generated and expelled petroleum that has migrated elsewhere. For these reasons, it is important to identify the mineralogical, chemical, depositional, diagenetic, and tectonic factors that collectively govern the size, grade, and distribution of the metalliferous and petroliferous deposits, as these 
factors will influence the choice of extractive process or processes necessary to recover these resources.

The economic potential of marine black shales in the Western United States is difficult to evaluate for a number of reasons:

1. The strata commonly are in allochthonous blocks above regional thrust faults, and generally are intensely deformed and broken. Both vertical and lateral continuity is virtually unpredictable without subsurface data, and reliable resource projections are generally limited to small, well-studied areas. Tectonic fracturing promotes accelerated weathering and erosion so that the shales are generally poorly exposed; in addition, the broken rocks are extensively leached by ground water and tend to be severely altered to substantial depths.

2. The rocks are generally fine to very fine grained (microclastic to microcrystalline), and megascopic field methods generally are ineffective in mineral or chemical identification. Even petrographic examination of standard thin sections is of limited value.

3. The sapropelic organic matter in these sediments is widely dispersed, and appears virtually opaque in standard thin sections.

4. The elements are so extensively dispersed that chemical and mineralogical studies must be conducted on a microscale.

Vanadium, zinc, selenium, and molybdenum occur in anomalously high concentrations in the Upper Devonian kerogenous marine Gibellini facies at the Gibellini and Bisoni properties on ridge 7129 in the Cockalorum Wash 15-minute quadrangle, southern Fish Creek Range, Eureka County, Nev. (fig. 1). The ridge is located $0.48 \mathrm{~km}$ west of the Gibellini manganese mine and about $4 \mathrm{~km}$ northwest of Eightmile well. The Gibellini facies at the Bisoni-McKay property $14.5 \mathrm{~km}$ to the south also is enriched in these metals.

\section{Acknowledgments}

We are particularly indebted to Geoffrey Snow of Noranda Exploration Inc. for providing drill-cutting samples, vanadium analytical data, maps, and diagrams that were all essential for our study and interpretations. We also thank Richard Schoenfeld of the U.S. Geological Survey for drafting the geologic map and block diagram (fig. 2). Ronald Keil of Geolabs Inc. provided quantitative analyses of zinc, selenium, and silver. Claudia True, formerly of the U.S. Geological Survey, provided data and interpretations on vitrinite reflectance of kerogen in sample 122.

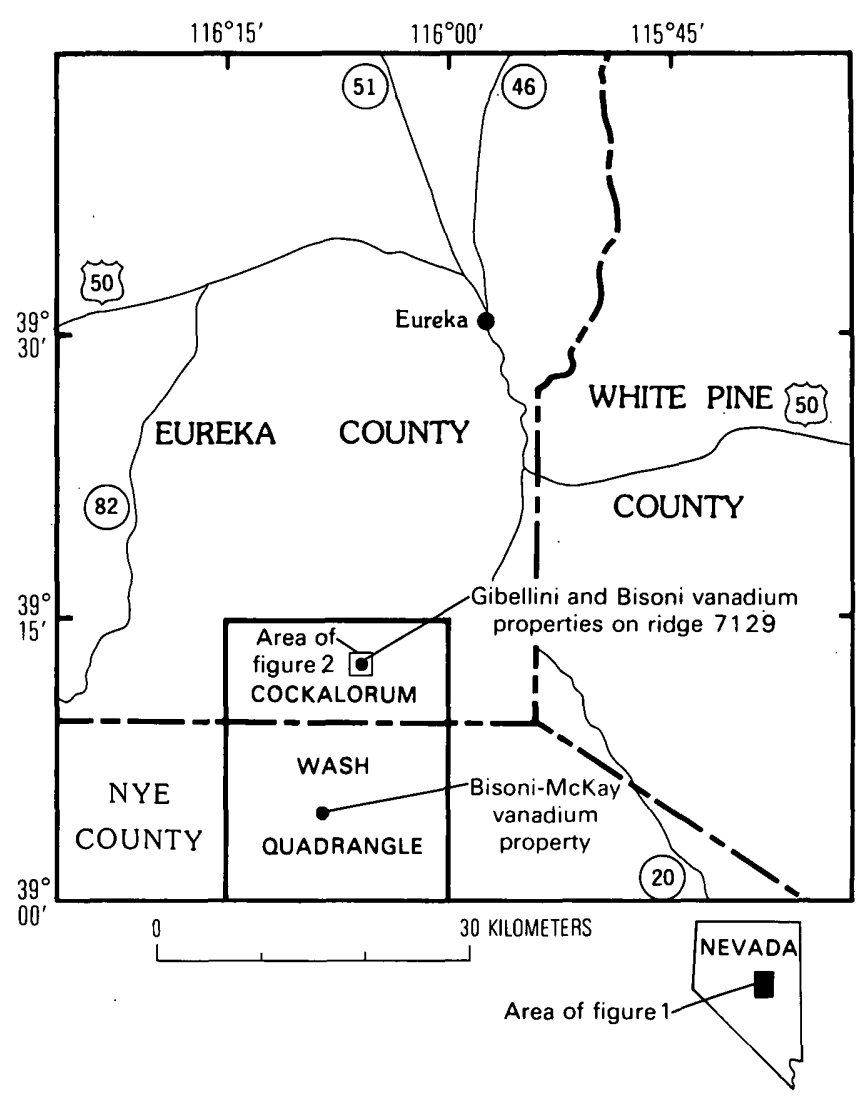

Figure 1. Location of Gibellini and Bisoni vanadium properties on ridge 7129, southern Eureka County, Nev., and BisoniMcKay vanadium property, northern Nye County, Nev.

\section{METHODS OF STUDY}

Vanadium has been known in high concentrations in the Gibellini facies in the southern Fish Creek Range for many years; in addition, analyses of drill cuttings and fresh outcrop samples in U.S. Geological Survey and other laboratories have revealed anomalously high concentrations of zinc, selenium, molybdenum, and nickel (Desborough and others, 1979; Böhlke and others, 1981).

Extensive drilling and sampling of the Gibellini property by Noranda Exploration Inc. provided the subsurface samples, and Dr. Geoffrey Snow of Noranda generously provided analytical data for vanadium. Splits of samples from two drill holes, NG-28 and NG-12 (fig. 2), have been quantitatively analyzed for several metals (table 1). The Fischer oil-assay yield and bulk mineralogy of these samples have also been determined.

Samples of twelve 5-ft $(1.5-\mathrm{m})^{2}$ composites from three widely spaced drill holes on the Bisoni McKay property and three $5-\mathrm{ft}(1.5-\mathrm{m})$ composites from two drill

\footnotetext{
${ }^{2}$ Measurements originally in feet, converted to metric for this study.
} 
Table 1. Concentration of selected elements for composite samples from drill holes NG-28 and NG-12, Gibellini vanadium property, Eureka County, Nev.

[Quantitative X-ray fluorescence analysis by G.N. Green; values in parts per million. Original depth measurements were in feet; 1 $\mathrm{ft}=0.3048 \mathrm{~m}$ ]

\begin{tabular}{|c|c|c|c|c|c|c|c|c|c|c|c|}
\hline $\begin{array}{c}\text { Depth } \\
(f t)\end{array}$ & V & $\mathrm{Fe}$ & $\mathrm{Ni}$ & $\mathrm{Zn}$ & As & $\mathrm{Se}$ & $\mathrm{Rb}$ & $\mathrm{Sr}$ & $\mathrm{Zr}$ & Mo & $\mathrm{U}$ \\
\hline \multicolumn{12}{|c|}{ Drill hole NG-28 } \\
\hline $\begin{array}{c}75-85 \\
85-95 \\
95-105 \\
105-115 \\
115-125\end{array}$ & $\begin{array}{l}1,960 \\
2,350 \\
2,180 \\
2,410 \\
2,300\end{array}$ & $\begin{array}{r}6,320 \\
10,300 \\
11,000 \\
11,800 \\
11,800\end{array}$ & $\begin{array}{r}<100 \\
210 \\
220 \\
610 \\
340\end{array}$ & $\begin{array}{r}670 \\
3,360 \\
6,700 \\
8,260 \\
4,580\end{array}$ & $\begin{array}{l}20 \\
40 \\
40 \\
40 \\
50\end{array}$ & $\begin{array}{l}70 \\
60 \\
55 \\
55 \\
50\end{array}$ & $\begin{array}{l}30 \\
40 \\
35 \\
30 \\
30\end{array}$ & $\begin{array}{l}120 \\
180 \\
120 \\
145 \\
120\end{array}$ & $\begin{array}{l}40 \\
60 \\
50 \\
45 \\
45\end{array}$ & $\begin{array}{r}80 \\
110 \\
105 \\
125 \\
115\end{array}$ & $\begin{array}{l}20 \\
40 \\
20 \\
50 \\
25\end{array}$ \\
\hline $\begin{array}{l}125-135 \\
135-145 \\
145-155 \\
155-165 \\
165-175\end{array}$ & $\begin{array}{l}2,460 \\
1,850 \\
2,240 \\
2,350 \\
1,500\end{array}$ & $\begin{array}{l}13,400 \\
20,500 \\
20,600 \\
11,100 \\
23,700\end{array}$ & $\begin{array}{l}260 \\
300 \\
475 \\
525 \\
235\end{array}$ & $\begin{array}{l}3,920 \\
4,530 \\
7,290 \\
6,910 \\
3,299\end{array}$ & $\begin{array}{l}40 \\
30 \\
55 \\
45 \\
35\end{array}$ & $\begin{array}{l}65 \\
45 \\
55 \\
50 \\
20\end{array}$ & $\begin{array}{l}45 \\
70 \\
60 \\
30 \\
90\end{array}$ & $\begin{array}{l}190 \\
275 \\
210 \\
170 \\
170\end{array}$ & $\begin{array}{r}65 \\
70 \\
65 \\
50 \\
100\end{array}$ & $\begin{array}{r}105 \\
70 \\
90 \\
120 \\
60\end{array}$ & $\begin{array}{l}45 \\
25 \\
25 \\
35 \\
20\end{array}$ \\
\hline \multicolumn{12}{|c|}{ Drill hole NG-12 } \\
\hline $\begin{array}{l}100-110 \\
110-120 \\
120-130 \\
130-140 * \\
140-150 *\end{array}$ & $\begin{array}{l}4,200 \\
3,860 \\
4,420 \\
3,250 \\
3,700\end{array}$ & $\begin{array}{r}3,950 \\
5,530 \\
10,300 \\
6,320 \\
7,900\end{array}$ & $\begin{array}{r}<100 \\
<100 \\
<100 \\
<100 \\
135\end{array}$ & $\begin{array}{r}<100 \\
<100 \\
<100 \\
135 \\
1,430\end{array}$ & $\begin{array}{r}<20 \\
20 \\
30 \\
20 \\
40\end{array}$ & $\begin{array}{l}275 \\
455 \\
265 \\
400 \\
415\end{array}$ & $\begin{array}{r}<20 \\
25 \\
40 \\
25 \\
20\end{array}$ & $\begin{array}{r}140 \\
130 \\
90 \\
100 \\
130\end{array}$ & $\begin{array}{l}20 \\
35 \\
40 \\
25 \\
25\end{array}$ & $\begin{array}{l}20 \\
15 \\
65 \\
35 \\
90\end{array}$ & $\begin{array}{l}60 \\
50 \\
45 \\
40 \\
45\end{array}$ \\
\hline $\begin{array}{l}150-160 * \\
160-170 \\
170-180 \\
180-190 \\
190-200\end{array}$ & $\begin{array}{l}3,360 \\
2,300 \\
1,620 \\
2,130 \\
1,900\end{array}$ & $\begin{array}{l}15,000 \\
22,100 \\
13,400 \\
14,200 \\
16,600\end{array}$ & $\begin{array}{r}410 \\
1,330 \\
480 \\
1,030 \\
575\end{array}$ & $\begin{array}{r}4,140 \\
18,800 \\
8,830 \\
13,900 \\
8,690\end{array}$ & $\begin{array}{r}55 \\
105 \\
45 \\
55 \\
80\end{array}$ & $\begin{array}{r}190 \\
85 \\
55 \\
60 \\
60\end{array}$ & $\begin{array}{l}60 \\
65 \\
25 \\
30 \\
35\end{array}$ & $\begin{array}{r}230 \\
175 \\
90 \\
80 \\
125\end{array}$ & $\begin{array}{r}60 \\
100 \\
35 \\
50 \\
55\end{array}$ & $\begin{array}{l}130 \\
700 \\
215 \\
415 \\
195\end{array}$ & $\begin{array}{l}35 \\
55 \\
40 \\
50 \\
35\end{array}$ \\
\hline
\end{tabular}

* Zone of less intense oxidation.

holes on the Gibellini property also were analyzed for vanadium, zinc, selenium, molybdenum, and silver.

Rock chips of subsurface samples from the Gibellini and Bisoni properties have been polished and studied by reflected light microscopy and electron microprobe methods. Fresh outcrop samples were obtained from rocks exposed by blasting and bulldozing (fig. 2, locality 122). Incipiently oxidized surface samples were obtained from rock outcrops (fig. 2, localities 116 and 120). These surface samples provided fragments large enough to evaluate gross texture and mineralogy, as well as material sufficient for organic-geochemical, microprobe, X-raydiffraction, palynologic, micropaleontologic, vitrinitereflectance, fluorescence-microscopic, Rock-Eval pyrolysis (Espitalié and others, 1977), oil yield, and maturation studies.

Methods for elemental analysis included atomic absorption and X-ray fluorescence. Vanadium, zinc, and selenium were analyzed by both methods, and good agreement was obtained. Iron, nickel, arsenic, rubidium, strontium, zirconium, molybdenum, and uranium were analyzed using bulk samples, an energy dispersive detector with a Cd 109 excitation source, and prepared standards. The concentration of the following elements is less than the following values, in ppm: $\mathrm{Mn} \mathrm{150,Cu}$ $150, \mathrm{Y} 40, \mathrm{~Pb} 25$. Silver was analyzed by atomic absorption analysis.

Owing to the microscopic grain size and microfabric of the siliceous sapropelic mudstones, siltstones, and cherts of the Gibellini facies, most megascopic methods of mineral and organic-matter identifications are inadequate. The microscopic grain size also limits the use of standard petrographic thin sections in identifying mineral and organic matter. Most of the organic material is amorphous and cannot be identified even with high magnification. 


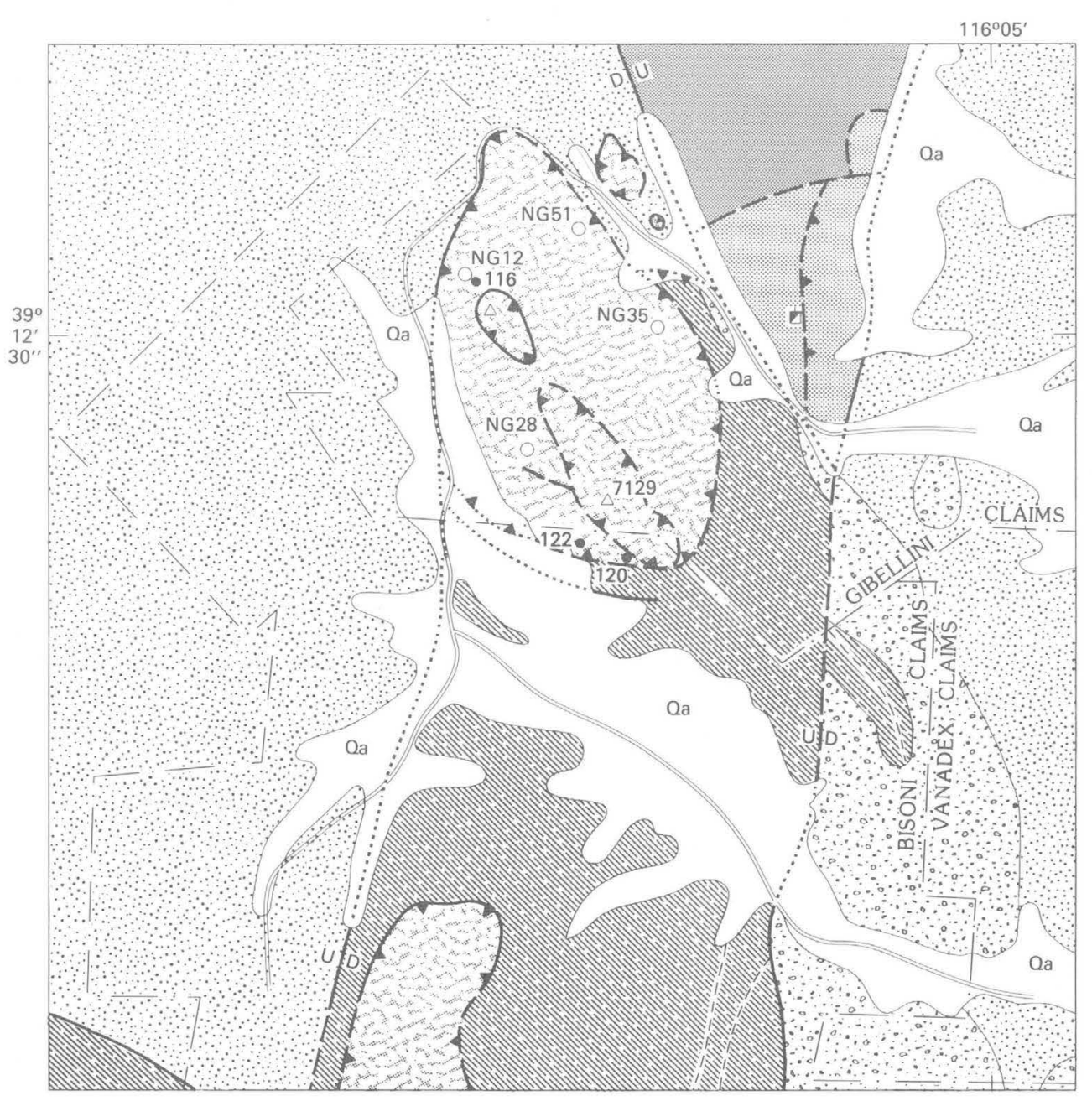

A
0.5 KILOMETERS

\section{EXPLANATION}

$$
\text { Qa }
$$

Unconsolidated colluvium and alluvium (Quaternary)
ALLOCHTHONOUS

$$
\text { Limestone bed }
$$

Webb Formation

Bisoni facies

(Mississippian)
AUTOCHTHONOUS (Mississippian)

Figure 2 (above and facing page). Gibellini and Bisoni properties and vicinity, southern Fish Creek Range, Eureka County, Nev, A, Geologic map (modified

from Hose, 1983). B, Exploded block diagram showing subsurface detail of Gibellini and Bisoni vanadium and zinc deposit, ridge 7129.

Upper member Antelope Range Formation

\section{UNCONFORMITY}

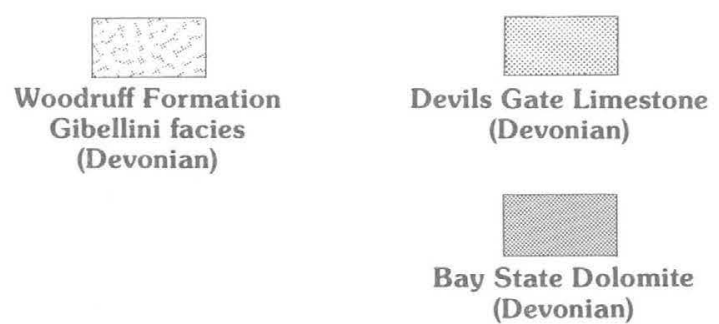
$\mathrm{U}$ Fault-Dashed where inferred, dotted where concealed; letters show relative vertical dis- placement
ـ _ Thrust fault-Dashed where inferred; dotted where concealed: queried where depth or extent uncertain; sawteeth on upper plate Claim boundary-Approximately located

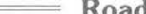
122. Sample locality
i Inclined shaft
NG12。 Drill hole




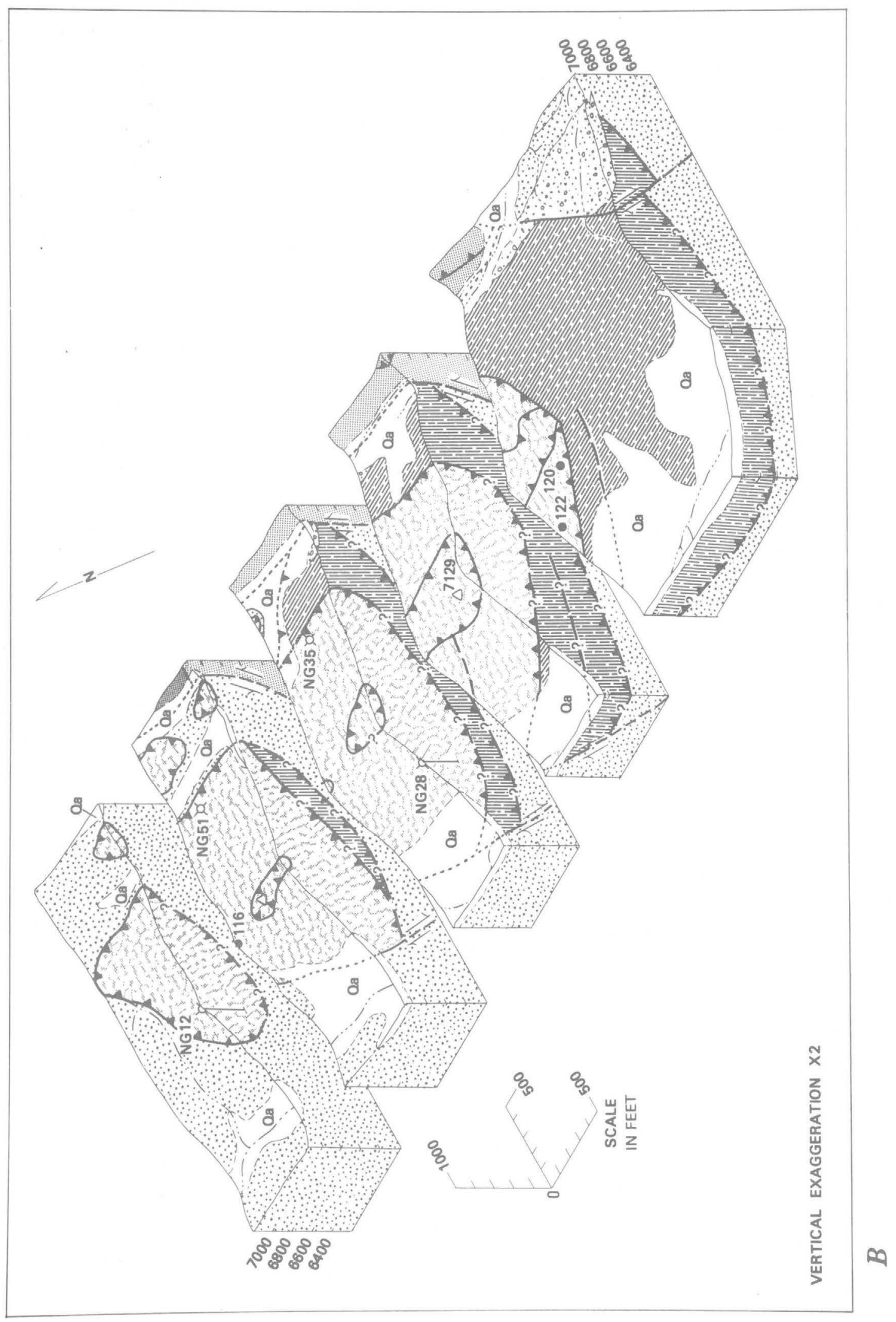




\section{STRATIGRAPHIC AND TECTONIC RELATIONS}

The Upper Devonian Gibellini facies of the Woodruff Formation at the Gibellini and Bisoni properties occurs as a northwest-trending allochthonous mass of organic-rich siliceous mudstone, siltstone, and chert, whose approximate dimensions are $700 \mathrm{~m}$ long, $300 \mathrm{~m}$ wide, and a minimum of $60 \mathrm{~m}$ thick (fig. 2). This mass, ridge 7129 , has a maximum relief of about $90 \mathrm{~m}$. The maximum thickness of the rock sequence is not known because the stratigraphic base and top have not been established, owing to structural complexities. Surface geologic relations, however, indicate that locally the maximum thickness may be as much as $100 \mathrm{~m}$. On ridge 7129 , the Gibellini facies is underlain structurally by the Bisoni facies of the Lower Mississippian Webb Formation, which consists chiefly of dolomitic and (or) argillaceous siltstone, siliceous mudstone, chert, and subordinate limestone, sandstone, and grit. Field studies and drill-hole information indicate that the vanadiferous Gibellini facies of the Woodruff Formation caps ridge 7129 and is separated by a low-angle thrust fault from the underlying nonmineralized Bisoni facies of the Webb Formation (fig. 2). Rocks of the Gibellini and Bisoni facies rest structurally on flysch deposits of the autochthonous lower Antelope Range Formation of Mississippian age. The Antelope Range Formation in the southern Fish Creek Range is underlain by the Devonian Devils Gate Limestone (fig. 2; Hose, 1983). On the southeast side of ridge 7129 , a depositional contact between the allochthonous Bisoni facies and overlapping molasse conglomerate beds of the upper Antelope Range Formation (fig. 2) suggests that the combined Gibellini and Bisoni facies form an exotic block $\left(>1.0 \times 10^{6} \mathrm{~m}^{3}\right)$ that detached from the eastern front of the moving Roberts Mountains allochthon in Early Mississippian time and slid eastward onto deposits of the lower Antelope Range Formation in the flysch trough (Poole and others, 1983). This exotic block subsequently was overlapped by coarse molasse deposits of the upper Antelope Range Formation.

At the Bisoni-McKay property (fig. 1) about $14 \mathrm{~km}$ to the south, the stratigraphic and structural relations between the Gibellini facies of the Woodruff Formation and adjacent rocks are less clear. Moreover, the Gibellini facies is more strongly deformed and consequently resource evaluation is more difficult. Here the Gibellini facies occurs as a north-northeast-trending, cigar-shaped, allochthonous mass of organic-rich siliceous mudstone, siltstone, and chert approximately $2,400 \mathrm{~m}$ long, $70 \mathrm{~m}$ wide, and $80 \mathrm{~m}$ thick.

\section{ROCK CONSTITUENTS}

The bedded siliceous sediments in the Gibellini facies of the Woodruff Formation on ridge 7129 consist largely of siliceous mudstone, siliceous siltstone, and banded chert layers. Unaltered strata are olive black, olive gray, brownish black, and brownish gray, whereas altered (weathered) strata are generally lighter shades of gray and brown, and locally (where intensely oxidized) yellow and red owing to the presence of secondary vanadium, selenium, and iron minerals. Fresh rocks in excavations oxidize rapidly as a result of surficial weathering, and a pinktinted coating of metahewettite $\left(\mathrm{CaO} \cdot 3 \mathrm{~V}_{2} \mathrm{O}_{5} \cdot 9 \mathrm{H}_{2} \mathrm{O}\right)$ forms at the surface and usually persists for several years. Rocks that have been exposed for longer periods lose this coating as the vanadium is dissolved and carried away.

The bedded siliceous mudstones, siltstones, and cherts of the Gibellini facies are irregularly laminated and color banded, and many beds appear to be diagenetically silicified fine-grained turbidites. Pyrite, marcasite, and sapropel are common constituents. Most fresh rock is fractured and veined with bluish-white chalcedonic quartz (fig. 3G) and sparse black solid bitumen. Some of the beds contain thin $(<2.5 \mathrm{~cm})$ layers of healed diagenetic breccia. Dark-colored laminae contain amorphous organic material. Sparse, poorly preserved algal cysts, radiolarians, and sponge spicules are the characteristic fossils seen in these siliceous rocks. The silica in the rocks is mostly microcrystalline, but it occurs also as fillings of algal cysts (fig. $3 A-D$ ).

The Gibellini facies in the southern Fish Creek Range contains no calcareous fossils and little carbonate of any type except minor carbonate-fluorapatite (table 2). The siliceous mudstones and siltstones are transitional into cherts by increase of silica and decrease in clay and sapropelic material. Most chert beds have wavy layering and locally are nodular; some look like diagenetically silicified very fine grained turbidites. Except for the $10 \AA$ mica and some quartz, all the minerals listed in table 2 are considered to be authigenic. In addition to chalcedonic quartz, the major authigenic minerals in the siliceous sediments on ridge 7129 are sphalerite, apatite, potassium feldspar, pyrite, and iron-chlorite (table 2). Marcasite and molybdenite are also present, but in small amounts, and were not detected by X-ray diffraction.

\section{Organic Constituents and Fossils}

The dark color of the siliceous mudstone, siltstone, and chert of the Gibellini facies results from black, 
Table 2. Oil yield obtained by modified Fischer assay analysis, and bulk mineralogy obtained by $\mathrm{X}$-ray diffraction for composite samples from drill holes NG-28 and NG-12, Gibellini vanadium property, Eureka County, Nev.

$[\mathrm{K}$, potassium; Fe, iron; original measurements were in feet; $1 \mathrm{ft}=0.3048$ $\mathrm{m}]$

\begin{tabular}{|c|c|c|}
\hline $\begin{array}{l}\text { Depth } \\
(\mathrm{ft})\end{array}$ & $\begin{array}{l}011 \\
(w t \cdot p c t)\end{array}$ & $\begin{array}{l}\text { Minerals in addition to quartz } \\
\text { (listed in order of abundance) }\end{array}$ \\
\hline & & Drill hole NG-28 \\
\hline $75-85$ & 2.8 & $\begin{array}{l}10 \AA \text { mica, K-feldspar, apatite, } \\
\text { Fe-chlorite. }\end{array}$ \\
\hline $85-95$ & 3.0 & $\begin{array}{l}\text { Sphalerite, K-feldspar, Fe-chlor- } \\
\text { lte, } 10 \AA \text { mica. }\end{array}$ \\
\hline $95-105$ & 3.6 & $\begin{array}{l}\text { Sphalerite, K-feldspar, pyrite, apa- } \\
\text { tite, Fe-chlorite, } 10 \AA \text { mica. }\end{array}$ \\
\hline $105-115$ & 3.3 & $\begin{array}{l}\text { Sphalerite, K-feldspar, pyrite, apa- } \\
\text { tite, } 10 \AA \text { mica, Fe-chlorite. }\end{array}$ \\
\hline $115-125$ & 3.2 & $\begin{array}{l}\text { Sphalerite, K-feldspar, pyrite, apa- } \\
\text { tite, } 10 \AA \text { mica. }\end{array}$ \\
\hline $125-135$ & 3.1 & $\begin{array}{l}\text { Sphalerite, K-feldspar, } 10 \AA \text { mica, } \\
\text { pyrite, apatite, Fe-chlorite. }\end{array}$ \\
\hline $135-145$ & 2.1 & $\begin{array}{l}10 \AA \text { mica, sphalerite, K-feldspar, } \\
\text { pyrite, apatite, calcite, Fe- } \\
\text { chlorite. }\end{array}$ \\
\hline $145-155$ & 2.4 & $\begin{array}{l}\text { Sphalerite, } 10 \AA \text { mica, pyrite, K- } \\
\text { feldspar, apatite, Fe-chlorite. }\end{array}$ \\
\hline $155-165$ & 2.8 & $\begin{array}{l}\text { Sphalerite, apatite, pyrite, } \mathrm{Fe}- \\
\text { chlorite, } 10 \AA \text { mica, calcite. }\end{array}$ \\
\hline \multirow[t]{2}{*}{$165-175$} & 1.3 & $\begin{array}{l}10 \AA \text { mica, sphalerite, } \mathrm{K} \text {-feldspar, } \\
\text { Fe-chlorite, marcasite. }\end{array}$ \\
\hline & & Drill hole NG-12 \\
\hline $100-110$ & $<.5$ & Apatite, $10 \AA_{0}^{\circ} \mathrm{mica}$. \\
\hline $110-120$ & $<.5$ & Apatite, $10 \AA \mathrm{mica}$. \\
\hline $120-130$ & $<.5$ & $10 \AA \mathrm{m} 1 \mathrm{ca}$. \\
\hline $130-140 *$ & 1.6 & Apatite, $10 \AA$ mica. \\
\hline $140-150 *$ & 3.5 & Apatite, $10 \AA$ mica, sphalerite. \\
\hline $150-160 *$ & 2.3 & $\begin{array}{l}10 \AA \text { mica, Fe-chlorite, sphal- } \\
\text { erite, pyrite, calcite. }\end{array}$ \\
\hline $160-170$ & 1.6 & $\begin{array}{l}\text { K-feldspar, sphalerite, } 10 \AA \text { mica, } \\
\text { pyrite, Fe-chlorite. }\end{array}$ \\
\hline $170-180$ & 3.1 & $\begin{array}{l}\text { Apatite, sphalerite, } 10 \AA \text { mica, } \\
\text { Fe-chlorite, pyrite. }\end{array}$ \\
\hline $180-190$ & 2.4 & $\begin{array}{l}\text { Sphalerite, } 10 \AA \text { mica, Fe- } \\
\text { chlorite, pyrite, K-feldspar, } \\
\text { apatite. }\end{array}$ \\
\hline $190-200$ & 2.5 & $\begin{array}{l}\text { Sphalerite, pyrite, K-feldspar, } \\
10 \AA \text { mica, Fe-chlorite, apatite. }\end{array}$ \\
\hline
\end{tabular}

* Zone of less intense oxidation.

sapropelic (principally algal), organic material. In fresh rock the organic matter is dominantly very fine grained kerogen consisting of flaky and stringy organism fragments less than $15 \mu \mathrm{m}$ (micrometers) in length, preferentially oriented parallel to bedding. Most of the organic matter examined microscopically is translucent and yellowish brown. Most of the kerogen is amorphous, probably owing to microbial alteration during sedimentation and early diagenesis, and only sparse organic remains can be recognized. Organic matter is generally abundant and forms as much as 12 weight percent of the rock. Round and flattened algal cyst fragments commonly are filled with opaline quartz (fig. $3 A-D$ ). Liquid oil was seen on some fracture surfaces in freshly broken unoxidized rock.

Surface sample 122 from ridge 7129 (figs. 2, 3) contains 11.5 weight percent organic carbon; 0.7 percent of the rock consists of chloroform-extractable bitumen $(7,300 \mathrm{ppm})$, and about 10.8 percent consists of carbon in kerogen. Less than 10 percent of the total organic matter consists of vitrinite, liptinite (mostly sporinites), and inertinite. Although most vegetal components are generally less than $15 \mu \mathrm{m}$ in length, algal cyst fragments about $50-150 \mu \mathrm{m}$ in diameter were found scattered throughout all sections studied (fig. 3A-D). Rock-Eval pyrolysis results on sample 122 were as follows: 13.9 weight percent organic carbon, $62.05 \mathrm{mg} / \mathrm{g} \mathrm{S}_{1}+\mathrm{S}_{2}, 0.05 \mathrm{~S}_{1} / \mathrm{S}_{1}+\mathrm{S}_{2}$, 423 hydrogen index, 16 oxygen index, and $416^{\circ} \mathrm{C}$ maximum pyrolytic temperature. Six additional unoxidized samples, including two from bulldozer cuts and four from drill cuttings, from both the Gibellini and Bisoni and Bisoni-McKay properties, were analyzed by Rock-Eval pyrolysis in order to characterize and evaluate the degree of thermal maturity of the organic matter. Poole and Claypool (1984, p. 209, table 1) reported these data; they concluded that these strata were not subjected to thermal regimes above $60{ }^{\circ} \mathrm{C}$ since deposition. The bitumen in sample 122 is 59 percent hydrocarbon with the balance being nonhydrocarbon asphaltic material. The sample contains $1,690 \mathrm{ppm}$ saturated hydrocarbons and 2,620 ppm aromatic hydrocarbons with a saturated-to-aromatic ratio of 0.7 and a hydrocarbon-to-organic carbon ratio (HC:C) of 3.76. The saturated-to-aromatic hydrocarbon ratio of 0.7 is consistent with the dominantly asphaltic content of the extract. Generally, HC:C values greater than 1 suggest either thermochemical conversion of solid organic matter to hydrocarbons or the presence of nonindigenous hydrocarbons. According to G.E. Claypool of the U.S. Geological Survey (written commun., 1978), gas chromatographic analysis of the saturated hydrocarbon fraction indicates a complex mixture dominated by branched and cyclic compounds, with the bulk of the material in the range of $n-C_{15}$ to $n-C_{25}$. The bulk rock yielded $51.7 \mathrm{~L} / \mathrm{t}$ (liters/metric ton) of syncrude oil by Fischer assay. Total sulfur in sample 122 is 2.16 weight 

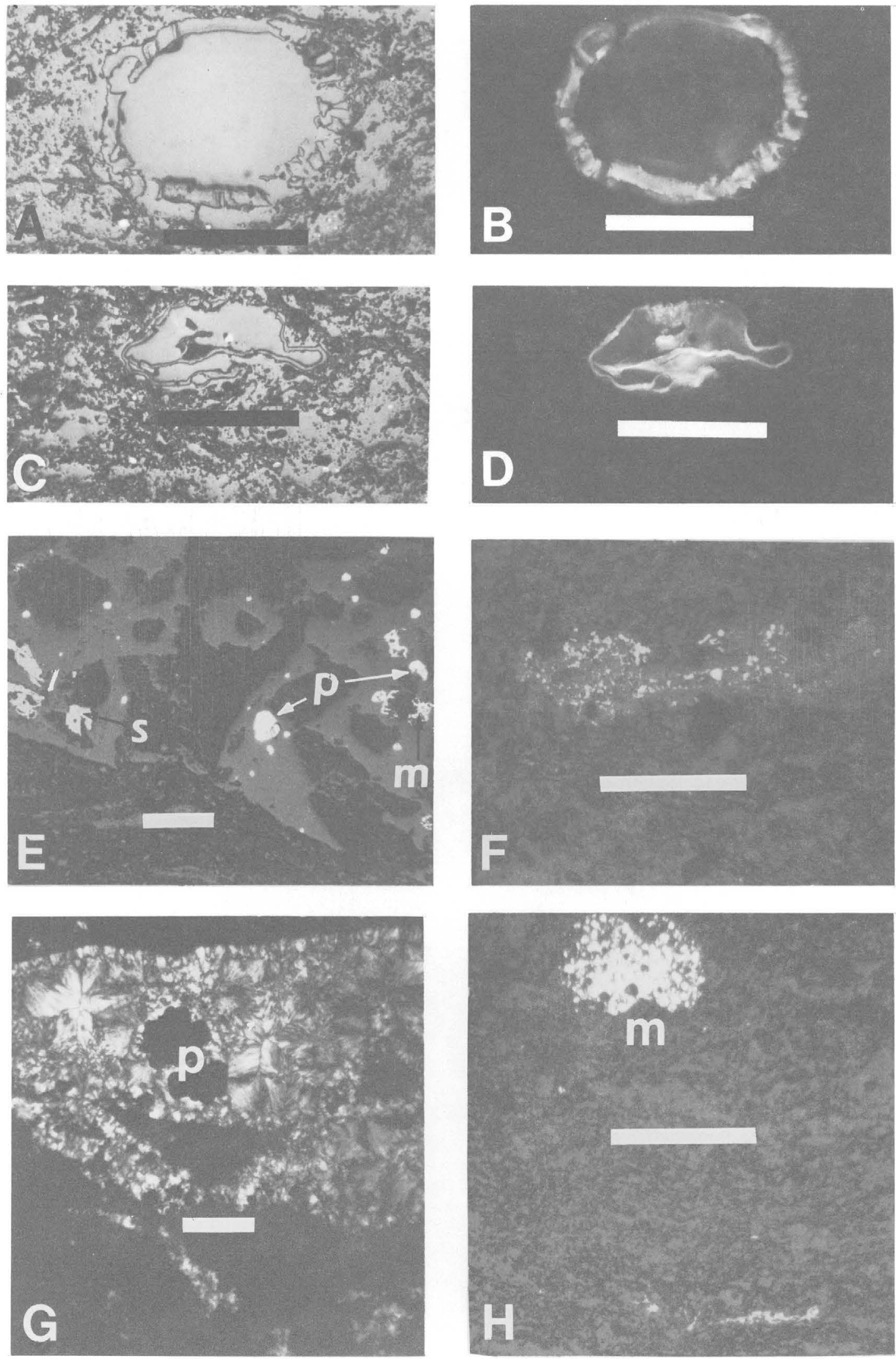
percent. Conodonts in the sample are pale yellow indicating a conodont color alteration index (CAI) of 1 , which suggests less than 60 percent fixed carbon and a maximum rock temperature of less than $60^{\circ} \mathrm{C}$ since deposition (Epstein and others, 1977). The vitrinite reflectance mean value of $0.43(n=23)$ for surface sample 122 is compatible with the conodont and palynomorph color alteration and other organic geochemical data (Poole and Claypool, 1984, table 1, loc. 23). These data indicate that the organic matter in the rock is immature and has not reached the postdiagenetic stage of catagenesis. G.E. Claypool (written commun., 1979) noted that red components of the hydrocarbon extract from sample 122 were retained on a silica-gel column during elution with n-heptane, but were partially removed during benzene elution. He considered the red material to be a vanadyl prophyrin or a selenium organic complex.

A composite sample of cuttings from drill hole NG-12 on ridge 7129 (fig. 2) taken 35.5 to $58 \mathrm{~m}$ below the surface averages 7.9 weight percent organic carbon and 1.5 weight percent sulfur. Rock-Eval pyrolysis results on the composite sample were as follows: 7.5 weight percent organic carbon, $35.32 \mathrm{mg} / \mathrm{g} \mathrm{S}_{1}+\mathrm{S}_{2}, 0.04 \mathrm{~S}_{1} / \mathrm{S}_{1}+\mathrm{S}_{2}$, 454 hydrogen index, 13 oxygen index, and $417{ }^{\circ} \mathrm{C}$ maximum pyrolytic temperature. The composite sample contains 5,000-5,600 ppm extractable hydrocarbons (saturated and aromatic fractions). The organic matter seen microscopically in cuttings is very fine grained, averaging 2-6 $\mu \mathrm{m}$ in maximum dimensions, although silica-filled cyst fragments $50-150 \mu \mathrm{m}$ in diameter were found in polished sections of the cuttings. The organic material occurs principally as pervasively disseminated amorphous debris that is intimately admixed with the small mineral grains. Unoxidized mudstone yields 1.6-3.6 weight percent (about 17-37 L/t) of oil (table 2) by Fischer-assay analysis. During Fischer-assay pyrolysis, a high content of water was derived from both dehydration of "opaline" silica and kerogen. Silica dehydration is verified by electron microprobe studies, during which the electron beam leaves a decomposition hole in the

Figure 3 (facing page). Photomicrographs of samples 121 and 122 showing texture and fabric of organic fragments, opaline silica, and sulfides. Bedding is parallel to bar scale on photos; all but $C$ in reflected light, bar scale is $100 \mu \mathrm{m}$. $A$, Core of opaline silica filling cyst fragment; $B$, Fluorescence photo of cyst in $A ; C$, Opaline silica filling flattened cyst fragment; $D$, Fluorescence photo of cyst fragment in $C ; E$, Sphalerite (s), pyrite $(p)$, and marcasite $(m)$ in opaline silica veinlet; $F$, Finegrained sphalerite disseminated in opaline silica bleb (black areas are voids due to plucking); C, Opaline silica veinlet containing euhedral pyrite $(p)$ (transmitted polarized light, crossed polars, polished thin section); $H$, Marcasite (m) framboid and sphalerite (gray area in lower part of photo).
$\mathrm{SiO}_{2} \cdot n \mathrm{H}_{2} \mathrm{O}$ phase, which does not happen with quartz. This phenomenon is the reason for using the term silica, although the X-ray diffraction pattern is that of quartz.

Surface sample 120 on ridge 7129 (fig. 2) is oxidized and most of the organic material has been removed $(0.21$ weight percent organic carbon). The sample is olive-gray nodular chert that weathers yellowish to pinkish gray and light brownish gray. The rock contains both marcasite and pyrite, and is strongly fractured, with most of the fractures healed with silica. In reflected-light examination under crossed nicols, round to subhedral grains of marcasite and pyrite can be seen that range in diameter from about 50 to $500 \mu \mathrm{m}$. Also, unoriented bluish-white veinlets of opaline-like silica (chalcedonic quartz) transect the rock. Red and yellow grains of metahewettite as long as $50 \mu \mathrm{m}$ are scattered through the chert, and metahewettite also was seen in a veinlet $25 \mu \mathrm{m}$ wide.

Organic geochemical data on two outcrop samples from the Bisoni-McKay property are given in table 1 (locality 24) of Poole and Claypool (1984). Their RockEval results are comparable to those we obtained for the Gibellini facies at ridge 7129.

Radiolarian tests and sponge spicules are locally abundant in the siliceous rocks of the Gibellini facies. Sparse conodonts, phosphatic linguloid brachiopods, algal cysts, and small pieces of plant material were seen in some mudstone specimens. Radiolarians composed of cryptocrystalline silica are largely resorbed, and most sponge spicules are obscure and appear to have been partially or marginally resorbed. Some beds, however, contain well-preserved radiolarians and sponge spicules that show little or no compaction and whose peripheries are sharply defined; an example is surface sample 116 (silicified siltstone) collected near drill hole NG 12 (fig. 2). The sample yielded radiolarians of Late Devonian age according to D.L. Jones of the U.S. Geological Survey (oral commun., 1978). Another sample collected from a chert bed near sample locality 122 (fig. 2) also yielded radiolarians of Late Devonian age according to Brian Holdsworth of the University of Keele, England (oral commun., 1978).

Conodonts on bedding plane surfaces collected from a 1-m-thick mudstone unit in the Gibellini facies at locality 122 by Poole and Green (August 27, 1981) were identified by C.A. Sandberg of the U.S. Geological Survey (written commun., 1981). They include the following taxa (and number of specimens): Palmatolepis rugosa rugosa (8), $P$. perlobata postera (9), Bispathodus stabilis (2), Mehlina strigosa (1), Branmehla inornata (2), Ozarkodina sp. (1), Neoprioniodus sp. (2), and Hindeodella sp. (2). The conodonts have a CAI of 1 , indicating a maximum rock temperature of less than $60^{\circ} \mathrm{C}$ (Epstein and others, 1977). The association of $P$. rugosa 
rugosa and $P$. perlobata postera occurs worldwide only in the Late Devonian (late Famennian) Upper Polygnathus styriacus and Lower Bispathodus costatus Zones. Sandberg's knowledge of the many occurrences of these subspecies in the Western United States suggested to him that this collection more likely represents the Upper $P$. styriacus Zone.

The marine algal cyst Tasmanites sinuosus Winslow was identified by R. M. Kosanke of the U.S. Geological Survey (written commun., 1981) in a mudstone bed at sample locality 122 on ridge 7129 (figs. 2, 3). In addition to Tasmanites in the mudstone sample, Kosanke recognized Hystrichosphaeridium cf. $H$. ohioensis Winslow and Punctatisporites sp. The middle Paleozoic range of Tasmanites sinuosus is compatible with the conodont age determination.

Conodont, foraminiferal, and radiolarian faunas from the Bisoni facies of the Webb Formation indicate an Early Mississippian (Kinderhookian to Osagean) age (Hose and others, 1979). Conodonts in thin $(<1 \mathrm{~m})$ limestone beds in the Bisoni facies near the southern margin of the map area shown in figure $2 A$ have a CAI of 1 , which is similar to that of the structurally overlying Gibellini facies.

Fragments of detrital vascular plant stems are common in the underlying autochthonous Mississippian Antelope Range Formation. A boulder of fossil wood was collected from the conglomeratic part of the upper Antelope Range Formation just beyond the southeast corner of the map area shown in figure 2 . The wood was identified by R.A. Scott of the U.S. Geological Survey (written commun., 1979) as Callixylon of Late Devonian to Early Mississippian age. The fossilwood clast suggests that large trees were growing on or along the eastern margin of the Antler orogenic highland. A western source for the silicified-wood boulder is indicated by associated gravels composed of quartzite and chert similar to lower and middle Paleozoic units exposed in the Antler orogen. The wood may have been silicified prior to its eastward transport by streams, whereby the boulder was incorporated in Upper Mississippian molasse deposits (Poole, 1981; Poole and Claypool, 1984, fig. 6B and C).

\section{Distribution and Concentration of Metals}

Metal concentrations and mineral assemblages in samples from drill hole NG-12 on ridge 7129 suggest that oxidized rock extends to a depth of approximately $49 \mathrm{~m}$, whereas the oil content suggests that the base of the oxidized zone may be at a depth of approximately $40 \mathrm{~m}$ (tables 1, 2). Hence, an intermediate zone of approximately $9 \mathrm{~m}$ in drill hole NG-12 represents a transition from intense oxidation above $40 \mathrm{~m}$ to fresh rock below $49 \mathrm{~m}$.
In order to accurately determine the lower contact of the metal-rich Devonian strata with underlying Mississippian siltstone and mudstone on ridge 7129 , cuttings were obtained from the deepest penetrations in drill holes NG-35 and NG-51 (fig. 2; table 3). Concentrations of vanadium, zinc, selenium, molybdenum, and silver are reported for these samples in table 3 . In contrast with the values for the vanadiferous Devonian strata in drill holes NG-35 and NG-51 shown in table 3, the underlying Mississippian siltstones contained less than $150 \mathrm{ppm}$ vanadium, $100 \mathrm{ppm}$ zinc, $20 \mathrm{ppm}$ selenium, and $20 \mathrm{ppm}$ molybdenum.

Table 3. Concentration of vanadium, zinc, selenium, molybdenum, and silver in composite samples from drill holes on the Gibellini (NG) and Bisoni-McKay (N-BM) properties, Eureka and Nye Counties, Nev.

[Values in parts per million. Original measurements were in feet; 1 $\mathrm{ft}=0.3048 \mathrm{~m}$ ]

\begin{tabular}{|c|c|c|c|c|c|}
\hline $\begin{array}{c}\text { Depth } \\
(\mathrm{ft})\end{array}$ & $\mathrm{V}$ & $\mathrm{Zn}$ & $\mathrm{Se}$ & Mo & $\mathrm{Ag}$ \\
\hline \multicolumn{6}{|c|}{ Dril1 hole NG-35: } \\
\hline $150-155$ & 1,180 & 1,100 & 20 & 80 & 2.5 \\
\hline \multicolumn{6}{|c|}{ Drill hole NG-51: } \\
\hline $140-145$ & 3,140 & 500 & 120 & 20 & 3.0 \\
\hline $155-160$ & 1,290 & 1,800 & 30 & 40 & 3.0 \\
\hline \multicolumn{6}{|c|}{ Drill hole N-BM-1: } \\
\hline $150-155$ & 780 & 300 & 440 & $<10$ & 8.0 \\
\hline $185-190$ & 500 & 300 & $<10$ & $<10$ & 3.5 \\
\hline $240-245$ & 450 & 200 & $<10$ & $<10$ & 3.5 \\
\hline \multicolumn{6}{|c|}{ Drill hole N-BM-2: } \\
\hline $90-95$ & 3,640 & 800 & $<10$ & 80 & 4.5 \\
\hline $150-155$ & 3,140 & 600 & 60 & 20 & 4.0 \\
\hline $190-195$ & 3,360 & 2,700 & 60 & 150 & 3.5 \\
\hline $225-230$ & 2,460 & 1,300 & $<10$ & 140 & 3.0 \\
\hline $275-279.5$ & 2,860 & 2,200 & 70 & 110 & 4.0 \\
\hline \multicolumn{6}{|c|}{ Drill hole N-BM-3: } \\
\hline $95-100$ & 620 & 200 & $<10$ & 10 & 5.0 \\
\hline $125-130$ & 560 & 200 & 30 & $<10$ & 6.0 \\
\hline $155-160$ & 500 & 300 & $<10$ & 10 & 6.5 \\
\hline $240-245$ & 1,120 & 400 & $<10$ & 100 & 2.0 \\
\hline
\end{tabular}

The vanadium in fresh (unoxidized) black rocks of the Gibellini facies on ridge 7129 occurs chiefly in organic material, with concentrations ranging from 1,500 to $3,700 \mathrm{ppm}$. Vanadium in oxidized and leached rocks ranges from 850 to $9,600 \mathrm{ppm}$. Average concentration of vanadium for thirteen $1.5-\mathrm{m}$ samples in the upper oxidized part (depth 3-23 m) of drill hole NG-28 (not shown in table 1) is $1,840 \mathrm{ppm}$. Average concentration of vanadium in eighteen $1.5-\mathrm{m}$ samples in the upper oxidized part of drill hole NG-12 (not shown in table 1) is $2,600 \mathrm{ppm}$. Because we cannot establish the initial 
distribution of vanadium in the oxidized strata, we cannot quantitatively assess the influence of oxidation and (or) ground-water leaching on the present distribution of vanadium. However, the highest concentrations of vanadium are in samples that are oxidized, and one 6-mthick zone (NG-12, depth 24-30 m) averages 7,140 ppm, which is more than twice the amount found in any sample of unoxidized strata.

Zinc in the Gibellini facies occurs in sphalerite, and selenium is chiefly in organic matter; molybdenum is mostly in organic material, but molybdenite has been identified. Concentrations of zinc in unoxidized rocks range from 4,000 to $18,800 \mathrm{ppm}$, whereas in oxidized rock they range from 30 to $100 \mathrm{ppm}$, showing strong depletion due to weathering. Concentrations of selenium in unleached rocks range from 20 to $85 \mathrm{ppm}$, but in oxidized and leached rocks they range from 190 to $455 \mathrm{ppm}$, indicating enrichment upon weathering. Concentrations of molybdenum in unoxidized rocks range from 60 to $700 \mathrm{ppm}$, whereas in oxidized and leached rocks they range from 20 to $60 \mathrm{ppm}$, showing strong depletion by weathering. Unoxidized surface sample 122 contains the following, in ppm: V 3,140, $\mathrm{Zn} \mathrm{2,570,} \mathrm{Ni} \mathrm{315,} \mathrm{Se} \mathrm{68,} \mathrm{and}$ Mo 252. The concentration of iron is usually greater in the unoxidized rocks, but oxidative leaching removes much of it from iron sulfides. Nickel concentrations in unoxidized rocks range as high as $1,330 \mathrm{ppm}$, but they are reduced to less than $100 \mathrm{ppm}$ in the oxidized zone. As much as $105 \mathrm{ppm}$ of arsenic is present in fresh rocks, but the arsenic concentration seems to be somewhat lower in the oxidized zone. No marked concentrations of $\mathrm{Rb}$, $\mathrm{Sr}$ or $\mathrm{Zr}$ were encountered. Uranium is moderately enriched in these sapropelic sediments, with concentrations from 20 to $60 \mathrm{ppm}$. Silver contents are in the range of 2-8 ppm, and seem to be highest in the oxidized rock (table 3).

Sparse, microcrystalline red metahewettite in microfractures in subsurface samples and in nodules of fresh surface samples of the unoxidized zone has been identified by $\mathrm{X}$-ray diffraction methods. Electron microprobe analysis for all elements heavier than oxygen revealed that calcium and vanadium were the only major constituents in the metahewettite.

Microscopic, electron microprobe, and X-ray diffraction studies of unoxidized drill cuttings and of the unoxidized samples obtained from excavations show that vanadium minerals are sparse. Most of the vanadium in unoxidized mudstone occurs in the organic matter, according to electron microprobe studies using both wavelength- and energy-dispersive spectrometers simultaneously. The $\mathrm{VK}_{\beta}$ peak was used for both qualitative and quantitative electron microprobe analyses because of the serious interference of the $\mathrm{TiK}$ and $\mathrm{VK}_{\alpha}$ peaks.

Concentration of vanadium in organic matter is in the range of about $0.3-3.0$ weight percent. The exact amount cannot be determined by electron microprobe analysis because even under lowest intensity beam conditions, the kerogen volatilizes immediately. Vanadium and sulfur are the chief components (heavier than oxygen) in the kerogen. Thus, virtually all the vanadium in the unoxidized and unleached mudstone is dispersed in kerogen at low concentrations.

Zinc occurs in widely dispersed grains of sphalerite that are generally less than about $40 \mu \mathrm{m}$ in diameter (fig. $3 E, F$, and $H$ ). Microprobe analysis shows that all sphalerite grains contain less than 0.1 weight percent of manganese and iron, but that cadmium is present locally. Cadmium constitutes as much as 6.0 weight percent of some grains, but generally constitutes 0.2 weight percent or less of the sphalerite. Pyrite and marcasite are also present as small, widely dispersed grains in the unoxidized mudstone; these grains are distributed completely independently of the sphalerite grains. Although volumetrically insignificant, the pyrite and marcasite are conspicuous microscopically owing to their high reflectance in comparison with other minerals in the rock.

Concentrations of selenium in kerogen are probably greater than 0.04 weight percent, but accurate determinations cannot be made because of decomposition of kerogen in the microprobe beam. The selenium dispersed in kerogen is concentrated during oxidation in the weathered zone where concentrations range from 190 to $455 \mathrm{ppm}$ (table 1). Minor amounts of selenium and arsenic were detected in iron sulfides concentrated from sample 122.

Molybdenum occurs in widely dispersed grains of molybdenite less than $5 \mu \mathrm{m}$ in diameter. It appears that most of the molybdenite grains were plucked from the polished sections during preparation. Molybdenum probably constitutes more than 0.01 weight percent of the kerogen, but like selenium, accurate determination cannot be made owing to decomposition of kerogen in the microprobe beam.

Unofficial reports indicate that the Gibellini facies at the Bisoni-McKay property may contain several million tons of rock with an estimated grade of as much as 0.44 percent $\mathrm{V}_{2} \mathrm{O}_{5}$. Concentrations of vanadium, zinc, selenium, molybdenum, and silver in composite samples from three drill holes on the Bisoni-McKay property are listed in table 3.

\section{CONCLUSIONS}

Siliceous marine sediments that contain abundant sapropel dominate the Gibellini facies of the Woodruff Formation. These silica-rich sediments of the Gibellini facies originally consisted of siliceous silts and muds, slimes, and oozes whose high organic content is derived mainly from microscopic phytoplanktonic organisms. In many beds, outlines of radiolarian tests and sponge spicules tend to be blurred and obscure, indicating some 
marginal resorption and some masking by kerogen or bitumen. During diagenesis, silica probably dissolved, reached saturation, and reprecipitated; at the same time, authigenic sulfide minerals of iron, zinc, molybdenum, and other metals formed. Pyrite and marcasite occur both in the matrix and in opaline-like silica veinlets, which indicates that their principal time of formation was during diagenesis.

Within the siliceous sediments, abundant amorphous, flaky and stringy organic matter is present, and probably includes remains of bacteria, phytoplankton (algae), zooplankton, and a minor amount of higher plants. The organic matter (kerogen and bitumen) includes, and is the source of, additional hydrocarbons produced by heating. The early-phase hydrocarbons (liquid oil and solid bitumen) present in the rock probably formed without any major thermal degradation of the kerogen. These hydrocarbons were probably released during diagenesis from complex nonhydrocarbon molecular structures originating from living organisms.

These kerogen-rich sediments were deposited in an area receiving organic debris from large volumes of nearsurface marine waters that contained abundant phytoplankton. Fine-grained mineral particles of terrigenous origin were sparse, or were chemically degraded during diagenesis, and organic sediments were not effectively diluted by hemipelagic sediments. Abundant kerogen of marine origin indicates anoxic bottom conditions.

The Gibellini facies of the Woodruff Formation appears to have been deposited in a continental-rise setting on the east side of a Devonian inner-arc basin (Poole and others, 1977) that periodically was anoxic, which allowed deposition and preservation of organic-rich sapropelic sediments. Anoxic bottom water (that is, minimal mixing with near-surface water) probably accounted for the preservation of the organic matter. Water depth was well below wave base-influence, and may have exceeded $100 \mathrm{~m}$. Although most of the organic matter is kerogen of marine origin, traces of vegetal macerals derived from land plants have been recognized.

The occurrence of opaline-silica veinlets, kerogen that yields significant amounts of syncrude oil (as much as $50 \mathrm{~L} / \mathrm{t}$ ), no significant thermal alteration of the kerogen (Poole and Claypool, 1984, p. 209, table 1), low vitrinite reflectance values $(<0.5$ percent), conodont color alteration index of 1 , and high ratio of hydrocarbon:organic carbon, collectively demonstrate that the Upper Devonian Gibellini facies of the Woodruff
Formation in the southern Fish Creek Range has not been subjected to thermal regimes above $60{ }^{\circ} \mathrm{C}$ since deposition.

\section{REFERENCES CITED}

Böhlke, J.K., Radtke, A.S., Heropoulos, Chris, and Lamothe, P.J., 1981, Spectroscopic geochemical study of vanadiferous marine sediments of the Gibellini claims, southern Fish Creek Range, Eureka County, Nevada: U.S. Geological Survey Open-File Report 81-32, 37 p.

Desborough, G.A., Poole, F.G., Hose, R.K., and Radtke, A.S., 1979, Metals in Devonian kerogenous marine strata at Gibellini and Bisoni properties in southern Fish Creek Range, Eureka County, Nevada: U.S. Geological Survey Open-File Report 79-530, $31 \mathrm{p}$.

Epstein, A.G., Epstein, J.B., and Harris, L.D., 1977, Conodont color alteration-an index to organic metamorphism: U.S. Geological Survey Professional Paper 995, 27 p.

Espitalié, J., Laporte, J.L., Madec, M., Marquis, F., Leplat, P., Paulet, J., and Boutefeu, A., 1977, Méthode rapide de caractérisation des roches mères, de leur potential pétrolier et de leur degré d'évolution: Revue de l'Institut Français du P'étrole, v. 32, no. 1 , p. 23-42.

Hose, R.K., 1983, Geologic map of the Cockalorum Wash quadrangle, Eureka and Nye Counties, Nevada: U.S. Geological Survey Miscellaneous Investigations Series Map I-1410, scale 1:31,680.

Hose, R.K., Wrucke, C.T., and Armstrong, A.K., 1979, Mixed Devonian and Mississippian conodont and foraminiferal faunas and their bearing on the Roberts Mountains thrust, Nevada: Geological Society of America Abstracts with Programs, v. 11, no. 7 , p. 446.

Poole, F.G., 1981, Molasse deposits of the Antler foreland basin in Nevada and Utah: Geological Society of America Abstracts with Programs, v. 13, no. 7, p. 530-531.

Poole, F.G., and Claypool, G.E., 1984, Petroleum source-rock potential and crude oil correlation in the Great Basin, in Woodward, J., Meissner, F.F., and Clayton, J.L., eds., Hydrocarbon source rocks of the Greater Rocky Mountain Region: Rocky Mountain Association of Geologists, p. $179-230$.

Poole, F.G., Sandberg, C.A., and Boucot, A.J., 1977, Silurian and Devonian paleogeography of the Western United States, in Stewart, J.H., Stevens, C.H., and Fritsche, A.E., eds., Paleozoic paleogeography of the western United States: Society of Economic Paleontologists and Mineralogists, Pacific Sec., Pacific Coast Paleogeography Symposium 1, p. 39-65.

Poole, F.G., Sandberg, C.A., and Green, G.N., 1983, Allochthonous Devonian eugeosynclinal rocks in southern Fish Creek Range of central Nevada: Geological Society of America Abstracts with Programs, v. 15, no. 5, p. 304. 